\title{
Hydrogeology and Analysis of the
}

Ground-Water-Flow System of the Eastern Shore, Virginia

United States Geological Survey Water-Supply Paper 2401

Prepared in cooperation wit Accomack County,

Northampton County, and the Virginia Water Control Board

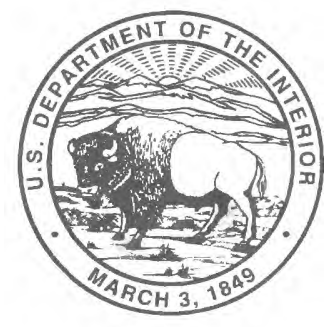




\section{Hydrogeology and Analysis of the Ground-Water-Flow System of the Eastern Shore, Virginia}

\section{By DONNA L. RICHARDSON}

Prepared in cooperation with Accomack County, Northampton County, and the Virginia Water Control Board 


\title{
U.S. DEPARTMENT OF THE INTERIOR BRUCE BABBITT, Secretary
}

\author{
U.S. GEOLOGICAL SURVEY \\ GORDON P. EATON, Director
}

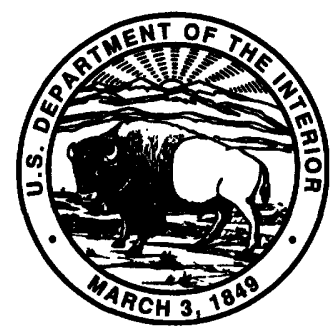

Any use of trade, product, or firm names in this publication is for descriptive purposes only and does not imply endorsement by the U.S. Government.

Printed in the Eastern Region, Reston, Va.

UNITED STATES GOVERNMENT PRINTING OFFICE: 1994

For sale by

U.S. Geological Survey, Map Distribution

Box 25286, MS 306, Federal Center

Denver, CO 80225

\section{Library of Congress Cataloging In Publication Data}

Richardson, Donna L.

Hydrogeology and analysis of the ground-water-flow system of the Eastern

Shore, Virginia / by Donna L. Richardson.

p. $\quad$ cm. - (U.S. Geological Survey water-supply paper ; 2401)

Includes bibliographical references.

Supt. of Docs. no.: I 19.13:

1. Water, Underground-Eastern Shore (Md. and Va.) 2. Groundwater

flow-Eastern Shore (Md. and Va.) I. Title. II. Series.

GB1025.V8R53 1994

$551.49^{\prime} 09755^{\prime} 1-d c 20$ 


\section{CONTENTS}

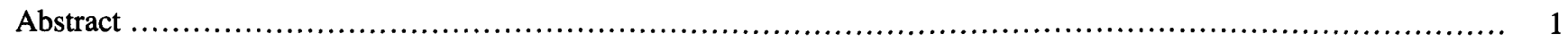

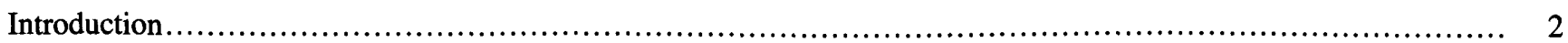

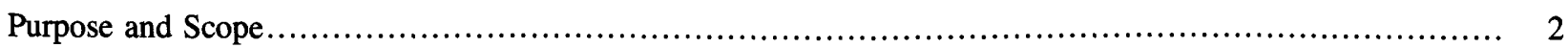

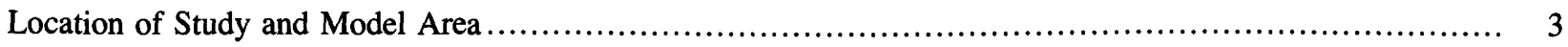

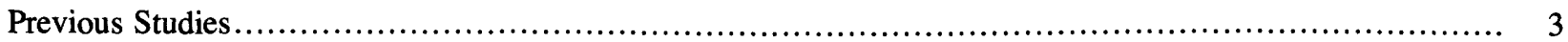

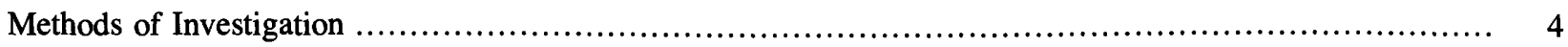

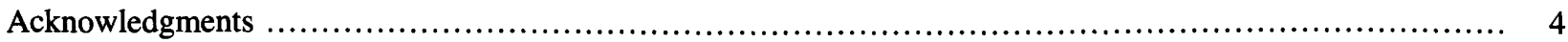

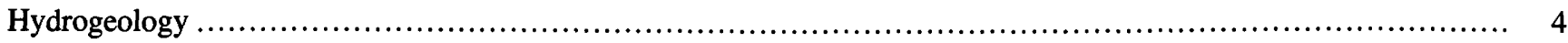

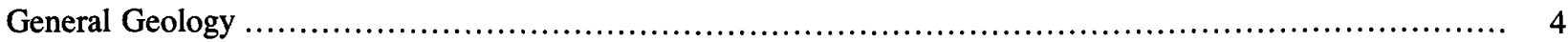

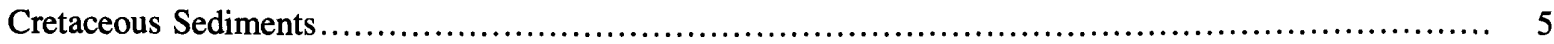

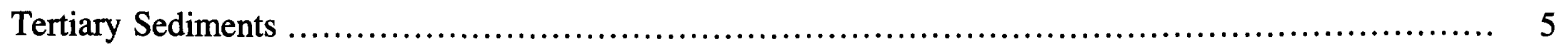

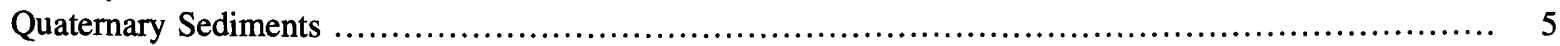

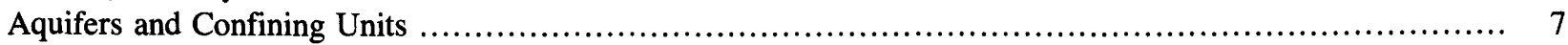

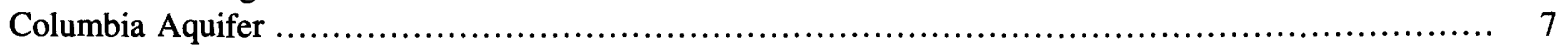

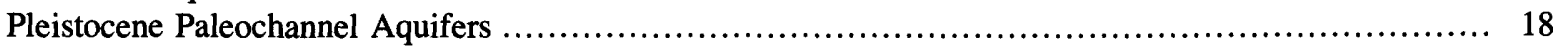

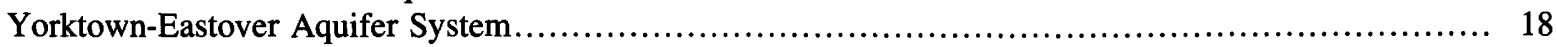

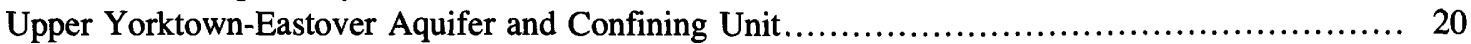

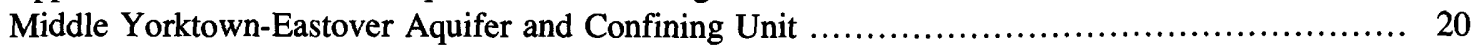

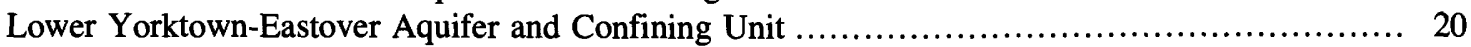

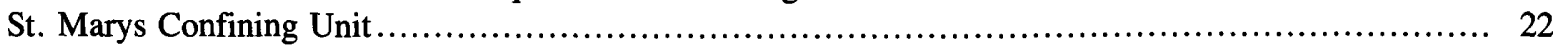

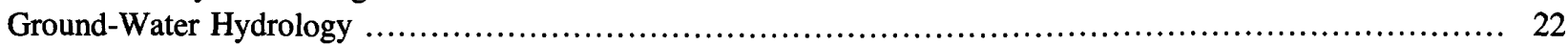

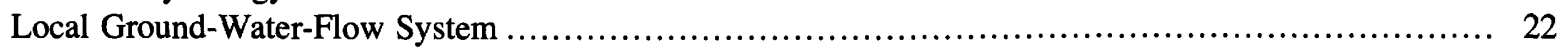

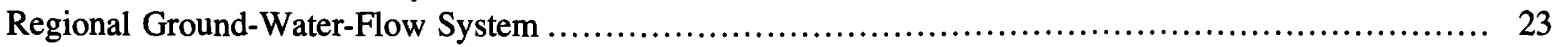

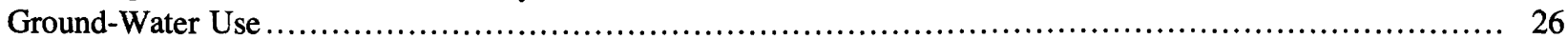

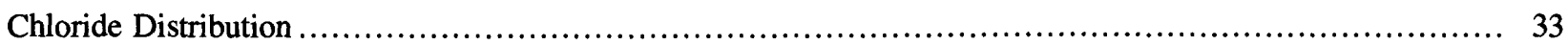

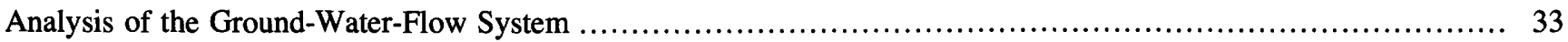

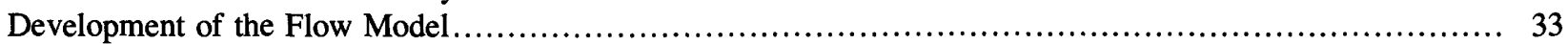

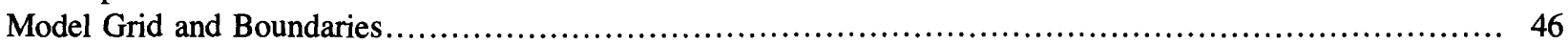

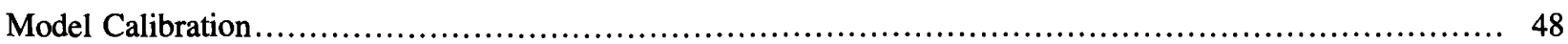

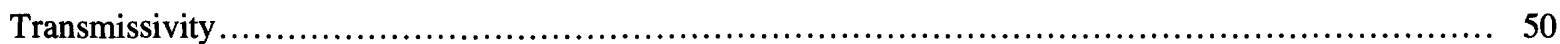

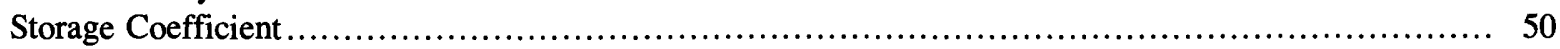

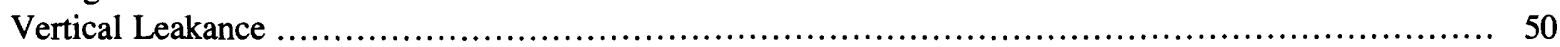

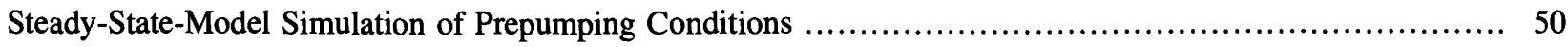

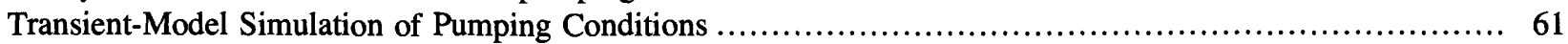

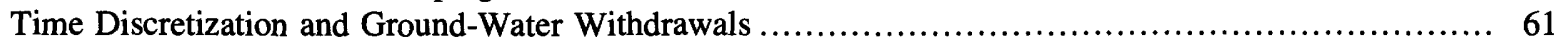

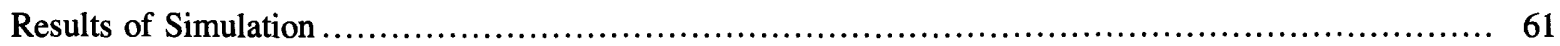

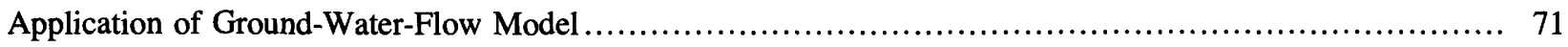

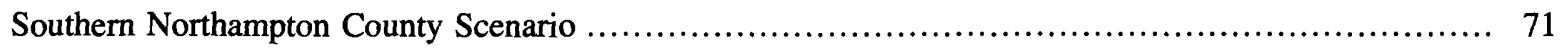

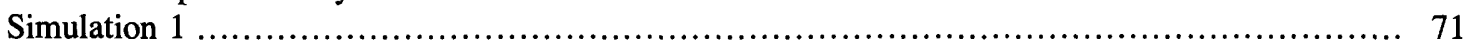

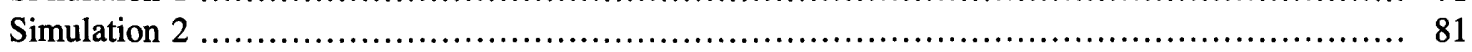

Northeastern Accomack County Scenario ..................................................... 85

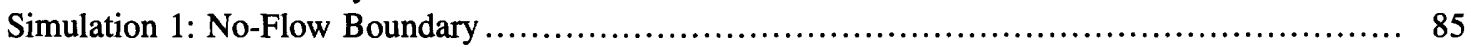

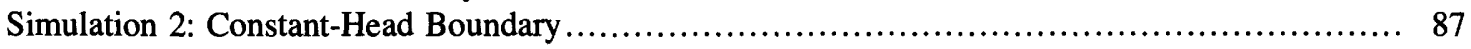

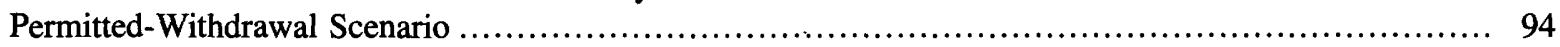

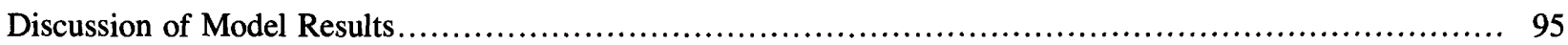

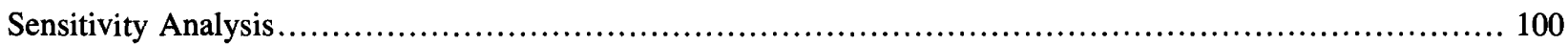


Model Limitations

\section{PLATE}

[In pocket]

1. Hydrogeologic sections for the Eastern Shore, Virginia

\section{FIGURES}

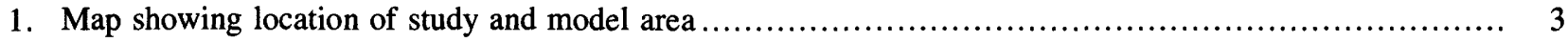

2. Map showing location of control wells used in hydrogeologic framework analysis ...................... 6

3-9. Hydrogeologic maps showing altitude of top of:

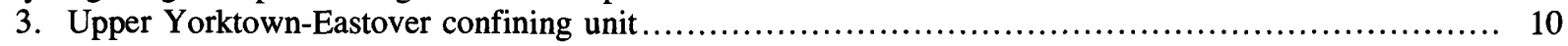

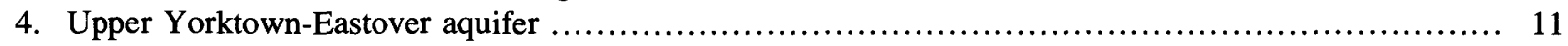

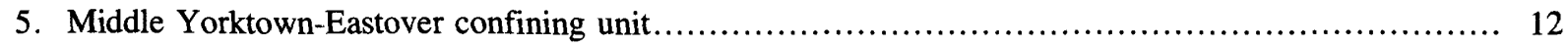

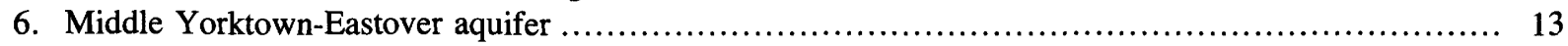

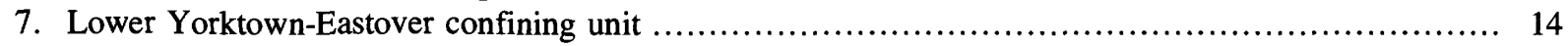

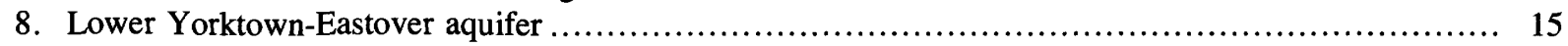

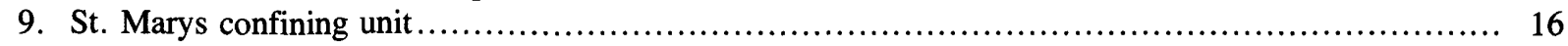

10. Schematic diagram of aquifers and confining units and generalized flow lines......................... 17

11,12. Maps showing:

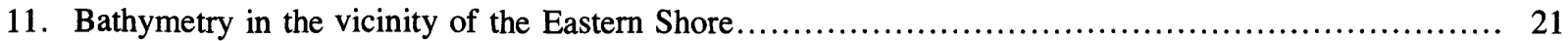

12. Locations of wells along transect $A-A^{\prime}$ in the Columbia aquifer ................................ 24

13,14. Graphs showing:

13. Water levels in selected wells along a transect $A-A^{\prime}$ in the Columbia aquifer ....................... 25

14. Water levels in an irrigation pond and in a nearby well completed in the Columbia aquifer ............ 26

15. Map showing location of selected Virginia Water Control Board research-station well clusters ............ 27

16. Graphs of water levels in research-station well clusters $(A)$ in a recharge area and $(B)$ in a discharge area .. 30

17. Map showing location of observation wells and chloride concentrations in the upper Potomac aquifer for

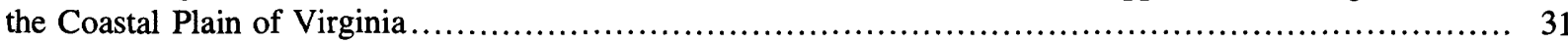

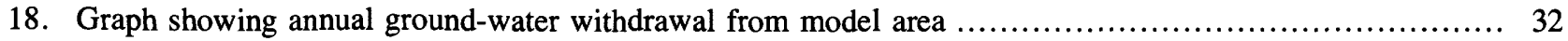

19-22. Maps showing chloride concentrations in:

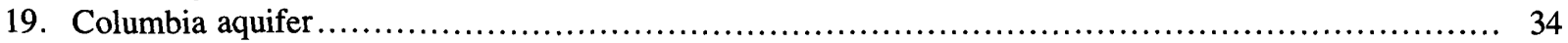

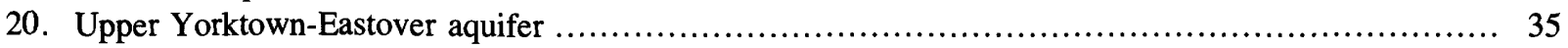

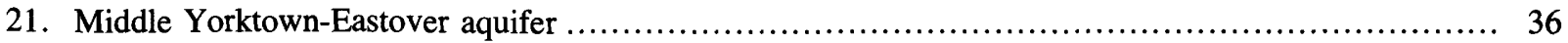

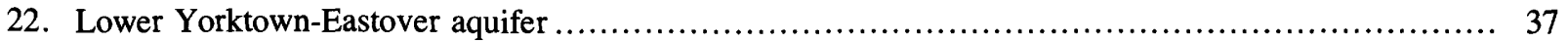

23. Schematic diagram of model representation of the saltwater-freshwater interface tip and toe .............. 46

24. Map showing finite-difference grid and boundaries used in model analysis ............................ 47

25. Schematic diagram showing physical and model conceptualizations of ground-water-flow system ........... 48

26. Map showing average water levels for the Columbia aquifer .......................................... 49

27-29. Maps showing hydraulic conductivity based on model calibration:

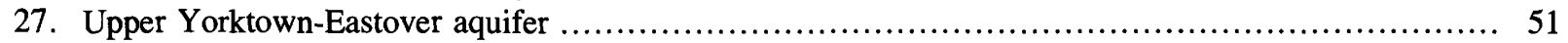

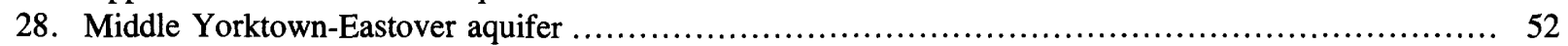

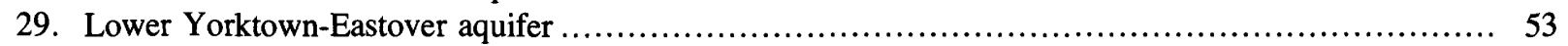

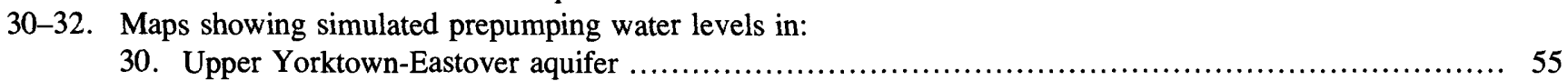

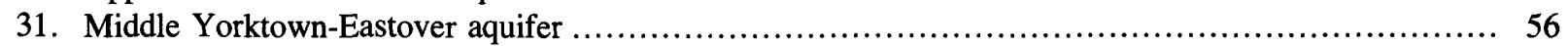

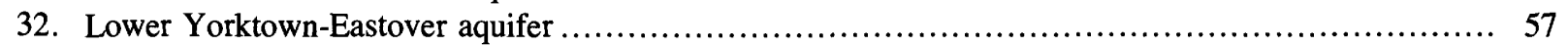

33-35. Maps showing simulated prepumping position of the saltwater-freshwater interface for:

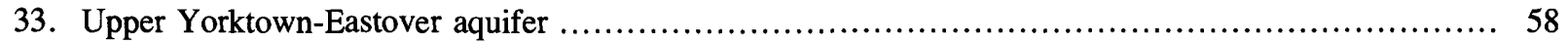

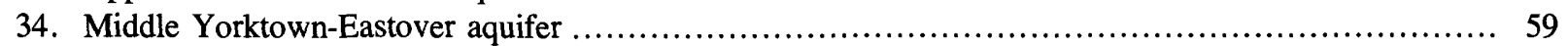

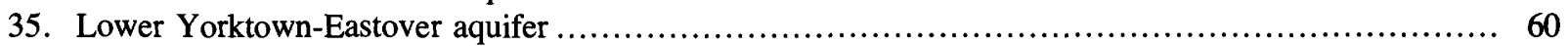

36. Graph showing estimated annual withdrawal and average withdrawal for simulated pumping periods........ 62 
37-39. Graphs showing simulated and measured water levels at selected observation wells in:

37. Upper Yorktown-Eastover aquifer

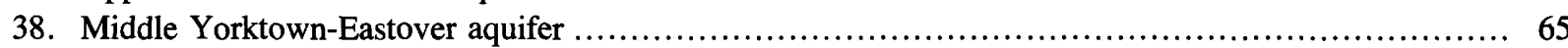

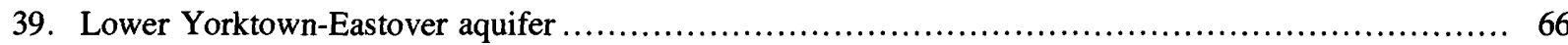

40-42. Maps showing simulated and measured water levels for 1988 in:

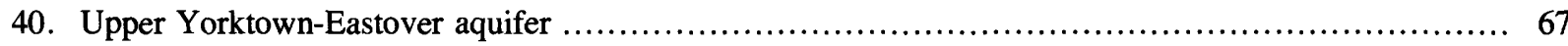

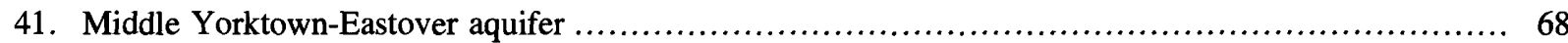

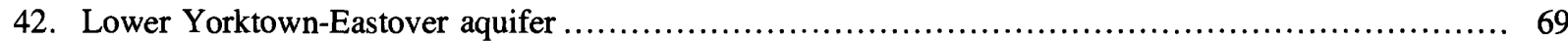

43-45. Maps showing simulated position of the saltwater-freshwater interface toe for a 1,000-year transient run using 1988 withdrawals in:

43. Upper Yorktown-Eastover aquifer

44. Middle Yorktown-Eastover aquifer

45. Lower Yorktown-Eastover aquifer

46. Map showing location of hypothetical withdrawals for the southern Northampton County scenario, simulation 1

47. Map showing water-level decline from simulated 1988 water levels, simulated position of the saltwater-freshwater interface toe, and area of reversed saltwater flow in the upper Yorktown-Eastover aquifer, southern Northampton County scenario, simulation 1

48,49. Maps showing water-level decline from simulated 1988 water levels and simulated position of the saltwater-freshwater interface toe for the southern Northampton County scenario, simulation 1, in:

48. Middle Yorktown-Eastover aquifer

49. Lower Yorktown-Eastover aquifer

50-52. Maps showing water-level decline from simulated 1988 water levels and simulated position of the saltwater-freshwater interface toe for the southern Northampton County scenario, simulation 2, in:

50. Upper Yorktown-Eastover aquifer

51. Middle Yorktown-Eastover aquifer

52. Lower Yorktown-Eastover aquifer

53. Map showing location of hypothetical withdrawals in the northeastern Accomack County scenarios

54. Map showing water-level decline from simulated 1988 water levels, simulated position of the saltwater-freshwater interface toe, and area of reversed saltwater flow in the upper Yorktown-Eastover aquifer, northeastern Accomack County scenario, simulation 1

55,56. Maps showing water-level decline from simulated 1988 water levels and simulated position of the saltwater-freshwater interface toe for the northeastern Accomack County scenario, simulation 1, in:

55. Middle Yorktown-Eastover aquifer

56. Lower Yorktown-Eastover aquifer

57. Map showing water-level decline from simulated 1988 water levels, simulated position of the saltwaterfreshwater interface toe, and area of reversed saltwater flow in the upper Yorktown-Eastover aquifer, northeastern Accomack County scenario, simulation 2

58,59. Maps showing water-level decline from simulated 1988 water levels and simulated position of the saltwater-freshwater interface toe for the northeastern Accomack County scenario, simulation 2, in:

58. Middle Yorktown-Eastover aquifer

59. Lower Yorktown-Eastover aquifer

60. Map showing location of permitted withdrawals

61. Map showing water-level decline from simulated 1988 water levels, simulated position of the saltwaterfreshwater interface toe, and area of reversed saltwater flow in the upper Yorktown-Eastover aquifer, permitted-withdrawal scenario

62,63. Maps showing water-level decline from simulated 1988 water levels and simulated position of the saltwater-freshwater interface toe for the permitted-withdrawal scenario in:

62. Middle Yorktown-Eastover aquifer

63. Lower Yorktown-Eastover aquifer ...

64-67. Maps showing the difference in simulated water levels for the southern Northampton County scenario, simulation 1, upper Yorktown-Eastover aquifer, resulting from:

64. A 50-percent increase in horizontal hydraulic conductivity

65. A 50-percent decrease in horizontal hydraulic conductivity 
66. A 50-percent increase in confining unit leakance

67. A 50-percent decrease in confining unit leakance

\section{TABLES}

1. Locations and depths of wells used to define the hydrogeologic framework and altitude of structural tops of hydrologic units for the Eastern Shore

2. Statistical summary of transmissivity and storage coefficients derived from aquifer-test results

3. Statistical summary of well yield, specific capacity, transmissivity, and horizontal hydraulic conductivity derived from specific-capacity tests

4. Vertical hydraulic conductivities derived from laboratory analyses of sediment cores from the Jenkins Bridge Research Station

5. Well-construction data for wells completed in the Columbia aquifer in a transect $A-A^{\prime}$ near Townsend $\mathrm{Va}$.

6. Selected Virginia Water Control Board research-station well clusters on the Eastern Shore .....

7. Vertical distribution of chloride concentrations in ground water at Jenkins Bridge and Kiptopeke Research Station well clusters

8. Chloride concentrations in the Columbia aquifer.

9. Chloride concentrations in the upper Yorktown-Eastover aquifer.

10. Chloride concentrations in the middle Yorktown-Eastover aquifer

11. Chloride concentrations in the lower Yorktown-Eastover aquifer .

12. Range of transmissivities estimated from specific-capacity data and from model calibration........

13. Minimum and maximum values of model storage coefficient

14. Minimum and maximum values of model vertical leakance

15. Withdrawals for each pumping period by aquifer

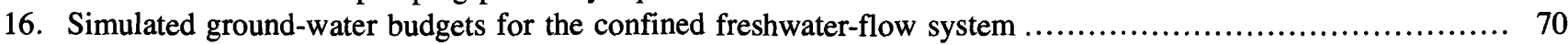

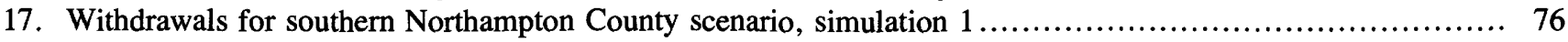

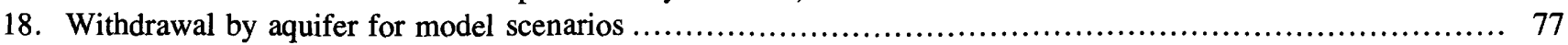

19. Maximum water-level decline from 1988 flow conditions for model scenarios ............................. 77

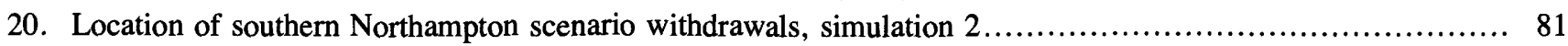

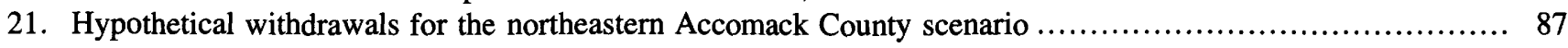

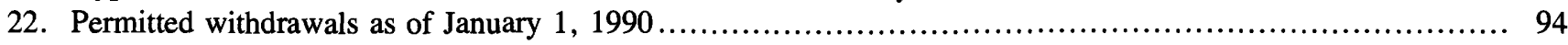

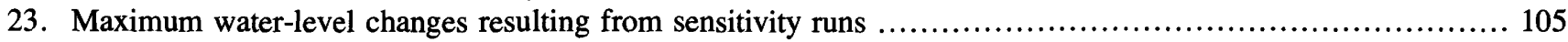


CONVERSION FACTORS AND VERTICAL DATUM

\begin{tabular}{rcl}
\hline Multiply & By & To obtain \\
\hline & Length & \\
\hline inch (in.) & 25.4 & millimeter $(\mathrm{mm})$ \\
foot (ft) & 0.3048 & meter $(\mathrm{m})$ \\
mile (mi) & 1.609 & kilometer $(\mathrm{km})$ \\
\hline & Area & \\
\hline square mile $\left(\mathrm{mi}^{2}\right)$ & 2.590 & square kilometer $\left(\mathrm{km}^{2}\right)$ \\
\hline & Volume & \\
\hline gallon $(\mathrm{gal})$ & 3.785 & liter $(\mathrm{L})$ \\
\hline & Flow & \\
\hline & .04381 & cubic meter per second $\left(\mathrm{m}^{3} / \mathrm{s}\right)$ \\
\hline million gallons per day $(\mathrm{Mgal} / \mathrm{d})$ & Hydraulic conductivity & meter per day $(\mathrm{m} / \mathrm{d})$ \\
\hline & .3048 & \\
\hline foot per day $(\mathrm{ft} / \mathrm{d})$ & Transmissivity & meter squared per day $\left(\mathrm{m}^{2} / \mathrm{d}\right)$ \\
\hline
\end{tabular}

Water-quality units: Water-quality units are expressed in this report as milligrams per liter $(\mathrm{mg} / \mathrm{L})$.

Hydraulic conductivity and transmissivity: In this report, hydraulic conductivity is reported in feet per day (ft/d), a mathematical reduction of the unit cubic foot per day per square foot $\left[\left(\mathrm{ft}^{3} / \mathrm{d}\right) / \mathrm{ft}^{2}\right]$.

Transmissivity is reported in feet squared per day $\left(\mathrm{ft}^{2} / \mathrm{d}\right)$, a mathematical reduction of the unit cubic feet per day per square foot times feet of aquifer thickness $\left(\left[\left(\mathrm{ft}^{3} / \mathrm{d}\right) / \mathrm{ft}^{2}\right] \mathrm{ft}\right)$.

Sea level: In this report, "sea level" refers to the National Geodetic Vertical Datum of 1929 (NGVD of 1929) - a geodetic datum derived from a general adjustment of the first-order level nets of both the United States and Canada, formerly called Sea Level Datum of 1929. 



\title{
Hydrogeology and Analysis of the Ground-Water-Flow System of the Eastern Shore, Virginia
}

\author{
By Donna L. Richardson
}

\section{Abstract}

This report presents the results of a study of the hydrogeology and ground-water-flow system of the Eastern Shore in Virginia by the U.S. Geological Survey in cooperation with Accomack County, Northampton County, and the Virginia Water Control Board. The Eastern Shore of Virginia is a peninsula that includes Accomack and Northampton Counties and is the easternmost part of Virginia's Coastal Plain physiographic province. Ground water provides the sole freshwater supply to the Eastern Shore. Water demands from increased industrial, commercial, municipal, and agricultural growth have caused water-level declines and concern about the future of the ground-water resource.

Detailed hydrogeologic information was collected and incorporated into the groundwater-flow model. The data were used to develop an understanding of the way ground water enters, moves through, and leaves the multiaquifer system. A hydrogeologic framework of the aquifers and confining units containing potable ground water was developed from geophysical and lithologic information. The hydrogeologic framework consists of an unconfined aquifer (Columbia aquifer) and three confined aquifers (upper, middle, and lower Yorktown-Eastover aquifers) separated by intervening confining units (upper, middle, and lower Yorktown-Eastover confining units). The ability of the aquifer and confining-unit sediments to transmit, store, and release water was defined by estimating values for transmissivity, vertical leakance, and storage. Transmissivities estimated from specific-capacity data range from 61 to 4,530 feet squared per day ( $\left.\mathrm{ft}^{2} / \mathrm{d}\right)$. Transmissivities generally are greater in the upper Yorktown-Eastover aquifer and decrease with depth in the middle and lower YorktownEastover aquifers. Annual ground-water withdrawals were compiled by aquifer for commercial, industrial, and municipal uses. Major pumping centers are located near the towns of Accomac, Cape Charles, Cheriton, Chincoteague, Exmore, Hallwood, and Oyster, Va. Total ground-water use was estimated to be about 5 million gallons per day in 1988. The upper, middle, and lower Yorktown-Eastover aquifers supplied 36,42 , and 22 percent of the total withdrawal in 1988, respectively. Data on chloride concentrations were compiled by aquifer to provide information on the distribution of chlorides in the study area. Chloride concentrations generally increase with depth; chloride concentrations are greater in the lower Yorktown-Eastover aquifer than are found in the overlying middle and upper Yorktown-Eastover aquifers.

A digital flow model was developed to aid in the analysis of the ground-water-flow system. The model incorporates the hydrogeologic characteristics of the aquifers and confining units, simulates freshwater and saltwater flow, and simulates the movement of the saltwater-freshwater interface. The effects of historical ground-water development were examined by comparing simulations of prepumping with past pumping conditions. Model results indicate that most of the ground water 
withdrawn from the system comes from an increase in the amount of water recharging the confined-aquifer system from the unconfined aquifer and a decrease in the amount of discharge from the confined-aquifer system to the unconfined aquifer. The simulation of prepumping conditions indicates that about 11 million gallons per day enter and exit the confinedaquifer system. Given 1988 withdrawal conditions, simulated flow into the confined-aquifer system is increased to about 13 million gallons per day, and simulated flow out of the confined-aquifer system is reduced to 8.64 million gallons per day. The position of the simulated saltwater-freshwater interface does not change in response to historical pumpage.

Three model scenarios of hypothetical increases in withdrawals provide information on the regional response of the ground-water system to additional pumping. Results indicate that (1) water levels continue to decline as withdrawals increase and could result in well interference among major ground-water users, (2) increases in withdrawals result in a decrease in the amount of offshore freshwater discharge, (3) water-level declines associated with increased withdrawals cause slight movement of the saltwater-freshwater interface over a 50-year simulation period, (4) increased withdrawals near the shoreline cause offshore water-level declines and a reversal in the direction of ground-water flow that could induce vertical leakage of saltwater into the freshwater parts of the uppermost confined aquifer, and (5) withdrawals near the center of the peninsula cause less landward movement of the saltwaterfreshwater interface than withdrawals near the shoreline.

\section{INTRODUCTION}

The Eastern Shore of Virginia includes Accomack and Northampton Counties and is the easternmost part of Virginia's Coastal Plain physiographic province. The Eastern Shore is a peninsula surrounded on three sides by salty water and has no major fresh surface-water sources; therefore, ground water provides the sole freshwater supply. Fresh ground water is present in a layered system of aqui- fers consisting of sand, gravel, and shell material separated by confining units of silt and clay. The fresh ground water is limited to approximately the first $300 \mathrm{ft}$ below land surface; the water at depths greater than $300 \mathrm{ft}$ is salty (greater than 250 milligrams per liter $(\mathrm{mg} / \mathrm{L})$ chloride concentration).

Beginning about 1965, increases in withdrawals for agricultural, commercial, and industrial uses have caused water-level declines and created conelike depressions in the water-level surface around major pumping centers. In November 1976 the Eastern Shore was declared a Ground-Water Management Area by the Virginia Water Control Board ${ }^{1}$ (VWCB). Under the management-area designation, a permit is required for ground-water users that withdraw more than 300,000 gallons per month (gal/month).

Increased water needs due to intensifying agricultural, industrial, commercial, and urban development could adversely affect the supply of fresh ground-water on the Eastern Shore. Potential problems are (1) declining water levels, (2) decreased freshwater discharge to nearshore estuaries,

(3) intrusion of salty water into freshwater parts of aquifers, and (4) contamination of potable water by the migration of pesticides and nitrates. A thorough knowledge of the ground-water-flow system is needed to enable planners to minimize the detrimental effects that would result from increased use of the resource. In 1986 the U.S. Geological Survey (USGS), in cooperation with the VWCB and the counties of Accomack and Northampton, began a comprehensive study of the ground-water resources of the Eastern Shore of Virginia.

\section{Purpose and Scope}

The purpose of this report is to describe the hydrogeology and ground-water-flow system of the Eastern Shore of Virginia. The report includes discussions of (1) the hydrogeologic framework of aquifers and confining units, (2) the flow of water through the multiaquifer system, (3) the hydraulic characteristics of aquifers and confining units, (4) the distribution of chloride concentrations in the aquifers, (5) the digital model used to simulate ground-water flow, and (6) the simulated effects of increased ground-water withdrawals.

\footnotetext{
${ }^{1}$ Predecessor of the Virginia Department of Environmental Quality - Water Division.
} 


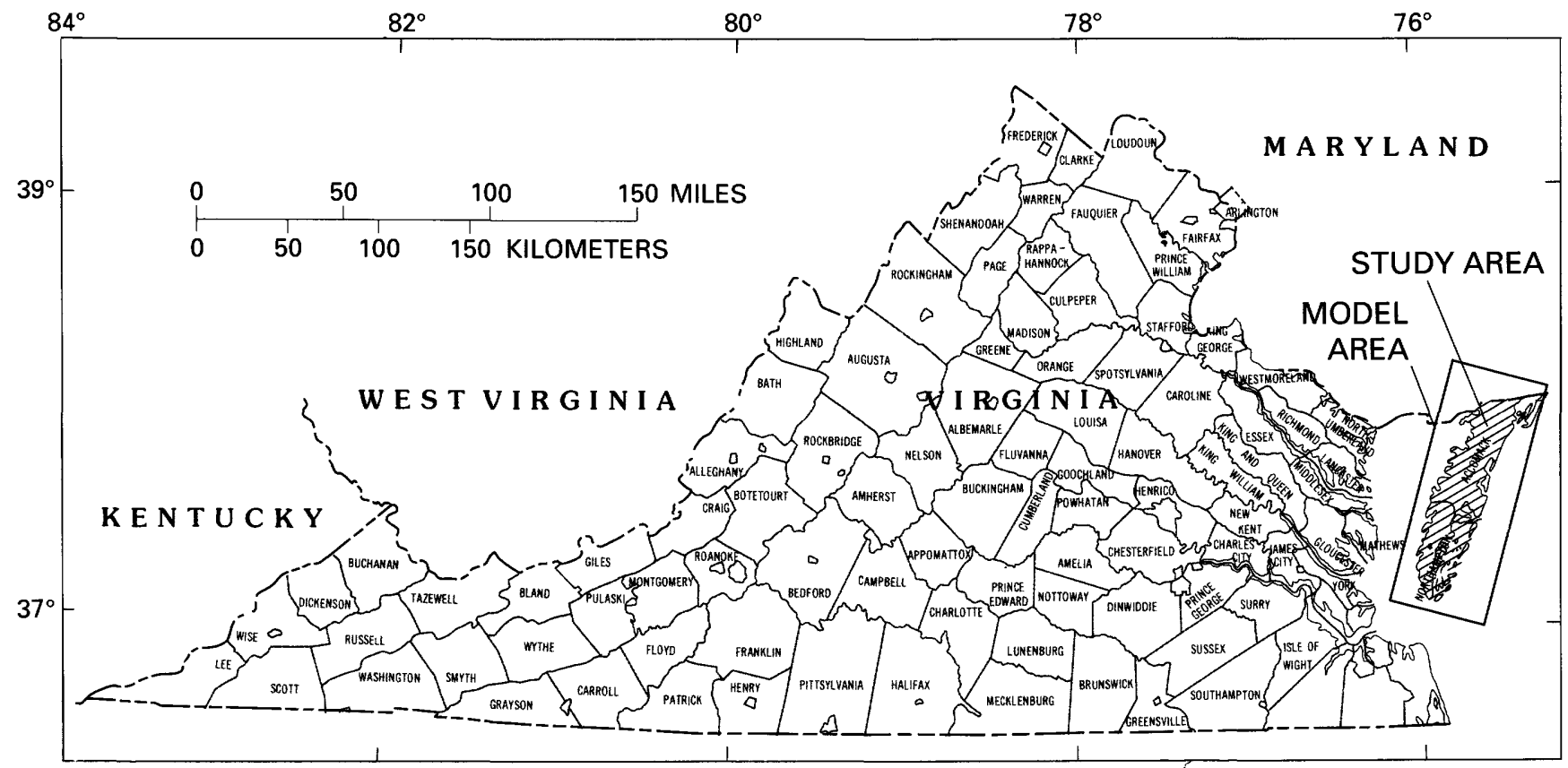

Figure 1. Location of study and model area.

This study is primarily an evaluation of the fresh ground-water-flow system of the Eastern Shore; therefore, the hydrogeologic data compiled for the study focus on the uppermost 300 feet (ft) of the system. Hydrogeologic data for aquifers and confining units of the Eastern Shore were collected, compiled, and analyzed. Hydraulic characteristics of the aquifers and confining units were estimated from hydrologic data. Water samples were collected and analyzed to determine the distribution of chloride concentrations in each aquifer. These data were used to develop a digital model of three-dimensional flow that simulates ground-water movement and tracks the lateral movement of the saltwater-freshwater interface.

\section{Location of Study and Model Area}

The study area includes Accomack and Northampton Counties in the easternmost part of Virginia's Coastal Plain physiographic province (fig. 1). The two counties are collectively referred to as the Eastern Shore of Virginia. The Eastern Shore is a peninsula that is about $70 \mathrm{mi}$ long and covers approximately 695 square miles $\left(\mathrm{mi}^{2}\right)$ of land area. It is bounded on the east by the Atlantic Ocean, on the west and south by the Chesapeake Bay, and on the north by the State of Maryland.
The model area extends into Maryland and includes offshore areas in the Atlantic Ocean and Chesapeake Bay, so that the effects of offshore saltwater flow could be incorporated into the model of the groundwater-flow system.

\section{Previous Studies}

Previous studies provide information about the ground-water resources of the Eastern Shore of Virginia. Sanford (1913) was the first to document the geology and ground water throughout the Virginia Coastal Plain. Sinnot and Tibbitts (1954, 1957, 1968) describe the ground-water resources of Northampton and Accomack Counties. Cushing and others (1973) provide a comprehensive study of the ground water of the Delmarva Peninsula. Siudyla (1975) and Siudyla and others $(1977,1981)$ present ground-water information for the Eastern Shore from a planner's perspective. Fennema and Newton (1982) present a summary of ground-water information for the Eastern Shore, and Bal (1977) developed the first digital ground-water-flow model for the area. Mixon (1985) describes the stratigraphy and geomorphic framework of the uppermost Cenozoic deposits in the southern Delmarva Peninsula. Knobel (1985) provides ground-water-quality data for the northern Atlantic Coastal Plain including the 
Eastern Shore. Harsh and Laczniak (1986) and Meng and Harsh (1988) contribute to the understanding of the ground-water resource by describing the hydrogeologic framework and conceptualization of ground-water flow for the Virginia Coastal Plain. Kull and Laczniak (1987) compiled ground-waterwithdrawal data for the Virginia Coastal Plain.

Several reports examine the distribution of saltwater in areas that include the Eastern Shore of Virginia. Cederstrom (1945) and Larson (1981) describe the distribution of chloride concentrations in the ground water of the Virginia Coastal Plain. Back (1966) describes the patterns of ground-water flow and the interface between freshwater and saltwater in the northern Atlantic Coastal Plain. Meisler and others (1985) document the distribution of salty ground water beneath the Atlantic Ocean in the northern Atlantic Coastal Plain aquifer system.

\section{Methods of Investigation}

The report by Meng and Harsh (1988) provided data that were used to develop the hydrogeologic framework described in this study. Additional hydrogeologic data were obtained from local well drillers and the VWCB to refine the framework for the fresh ground-water system of the Eastern Shore. Two clusters of observation wells were drilled by the VWCB to provide additional hydrologic information and further define the ground-water-flow system.

Water levels were measured to provide information on ground-water flow through the multiaquifer system. An established water-level network was expanded to a total of 58 wells, and water levels were measured every 6 weeks by the VWCB. Historic water-level data were compiled for use in model development. A transect of wells in the unconfined aquifer was constructed across the peninsula in southern Northampton County to improve the understanding of ground-water flow in the unconfined aquifer. Aquifer-test and specific-capacity data were reviewed to define the hydraulic characteristics of the aquifers.

Data obtained from the USGS water-use data base and the VWCB were reviewed for errors and compiled by aquifer through 1988 . Water-use data for the Eastern Shore consist of pumpage for major industrial, municipal, commercial, and public-supply systems. Pumpage for agricultural use is not accu- rately reported; therefore, withdrawals for irrigation are not included in the pumpage estimates.

Data on chloride concentrations and distributions throughout the study area were compiled from previous investigations. Additional water samples were collected and analyzed for chlorides during this study.

SHARP, a quasi-three-dimensional, digital, ground-water-flow model, was used to simulate past and present ground-water-flow conditions. The SHARP model simulates freshwater and saltwater flow and tracks the lateral movement of the saltwater-freshwater interface (Essaid, 1990a). Simulations of hypothetical withdrawal scenarios were used to assess potential changes in water levels, ground-water flow, and saltwater-interface position. These scenarios are intended to identify the general nature of the response of the hydrologic system to various stresses. The scenarios are not intended to predict specific future problems.

\section{Acknowledgments}

The author would like to thank Keith Bull, former Northampton County administrator, for his support of this study. Terry Wagner, Virginia Newton, Scott Bruce, and Eugene Powell of the Virginia Water Control Board provided data and support. Special thanks also are extended to local drillers for providing well-construction data and other pertinent hydrogeologic information.

\section{HYDROGEOLOGY}

The Eastern Shore of Virginia is the easternmost part of Virginia's Coastal Plain physiographic province. The Coastal Plain consists of layered, unconsolidated, sedimentary deposits that thicken and slope seaward. These deposits consist of interbedded clay, silt, sand, and gravel and variable amounts of shell material that form a system of layered aquifers and confining units.

\section{General Geology}

The sedimentary deposits composing the Eastern Shore generally thicken and dip northeastward and range in thickness from about 3,000 ft west of the peninsula to about $7,500 \mathrm{ft}$ east of the peninsula (Meng and Harsh, 1988). These Coastal Plain 
deposits overlie a hard-rock surface, commonly referred to as "basement," that also dips northeastward. The geologic age of these unconsolidated sediments ranges from Early Cretaceous to Holocene. The sediments have a varied depositional history. The lower 70 percent of the sediments are of Early to Late Cretaceous age and were deposited in fluvial environments (Robbins and others, 1975). The remaining 30 percent of the sediments are mostly of Tertiary age and were deposited in marine environments (Cushing and others, 1973). The Tertiary sediments are overlain by a thin veneer of sediments of Quaternary age that were deposited in various environments (Mixon, 1985). Figure 2 shows the location of control wells used in the development of the hydrogeologic framework of aquifers and confining units for the Eastern Shore.

\section{Cretaceous Sediments}

Most of the Cretaceous sediment underlying the Eastern Shore is commonly referred to as the Potomac Formation (Meng and Harsh, 1988) or the Potomac Group (Robbins and others, 1975). Information is limited concerning the composition and lithology of these Cretaceous sediments beneath the Eastern Shore. The most complete source of geologic data available is a deep oil-test hole in Temperanceville, Va. (66M1, fig. 2). The Potomac Formation beneath Virginia's Eastern Shore is probably similar in composition and lithology to that of surrounding areas (Meng and Harsh, 1988; Glaser, 1969; Hansen, 1969; Robbins and others, 1975). These deposits in the Virginia Coastal Plain range in age from Early to early Late Cretaceous (Robbins and others, 1975) and are characteristically heterogeneous in composition, consisting of interlayered and intermixed clay, silt, sand, and gravel deposits that mainly are a result of fluvial deposition. Current interpretations suggest that the sediments in the eastern part of the Virginia Coastal Plain (including the Eastern Shore) probably were deposited in a marginal-marine environment. The thickness of the Cretaceous sediments beneath the Eastern Shore ranges from about 2,000 to $5,600 \mathrm{ft}$.

The Early and early Late Cretaceous sediments are overlain by late Late Cretaceous sediments deposited in marginal-marine to marine environments. Information is limited concerning the composition and lithology of these uppermost Cretaceous deposits; however, in addition to data avail- able from well $66 \mathrm{M} 1$, data are also provided by the VWCB research stations at Jenkins Bridge (well 66M23, fig. 2), Accomack County, Va. These Late Cretaceous deposits vary in composition from clayey, shelly, glauconitic sands to chalky marl and range in thickness from 50 to $60 \mathrm{ft}$ in the northeastern part of Accomack County.

\section{Tertiary Sediments}

The Late Cretaceous sediments are overlain by a sequence of marine sediments of Tertiary age. The Tertiary sediments underlying the Eastern Shore are divided into a series of formations by depositional environment, texture, grain size, and lithology. As is true for the underlying Cretaceous sediments, information is limited concerning the composition, lithology, and nature of most Tertiary deposits beneath the Eastern Shore. If the Tertiary sediments are similar to those beneath the Virginia mainland, they are really extensive and homogeneous in character, forming layered sequences of clay, silt, and sand and varying amounts of shell material. The probable Tertiary formations, from oldest to youngest, are the Brightseat, Aquia, Nanjemoy, Piney Point, Chickahominy, Old Church, Calvert, Choptank, St. Marys, Eastover, and Yorktown Formations. Geologic data for these Tertiary units on the Eastern Shore are from the deep wells 66M1 and $66 \mathrm{M} 23$. An additional source of information for the deep Tertiary sediments is a stratigraphic core hole (well 64J14, fig. 2) that was drilled by the USGS at the Virginia Truck Experimental Station north of Exmore, Va. (R.B. Mixon, U.S. Geological Survey, oral commun., 1986). Preliminary analyses of these cores indicate an extremely thick Eocene section, overlain by a sequence of Oligocene, Miocene, and Quaternary deposits. In the Miocene sediments, the Calvert Formation contains a sand facies overlain by a clay-silt facies. The thickness of the Tertiary sediments ranges from 1,000 to $1,500 \mathrm{ft}$.

\section{Quaternary Sediments}

As sea levels fluctuated with the advance and retreat of continental ice sheets during the Pleistocene Epoch, the drainage patterns of the major river systems in the Chesapeake Bay area were altered, eroding channels into previously deposited sediments. As sea levels declined with the advance of the glaciers, streams flowed eastward across the Eastern Shore, deeply dissecting (more than $200 \mathrm{ft}$ 


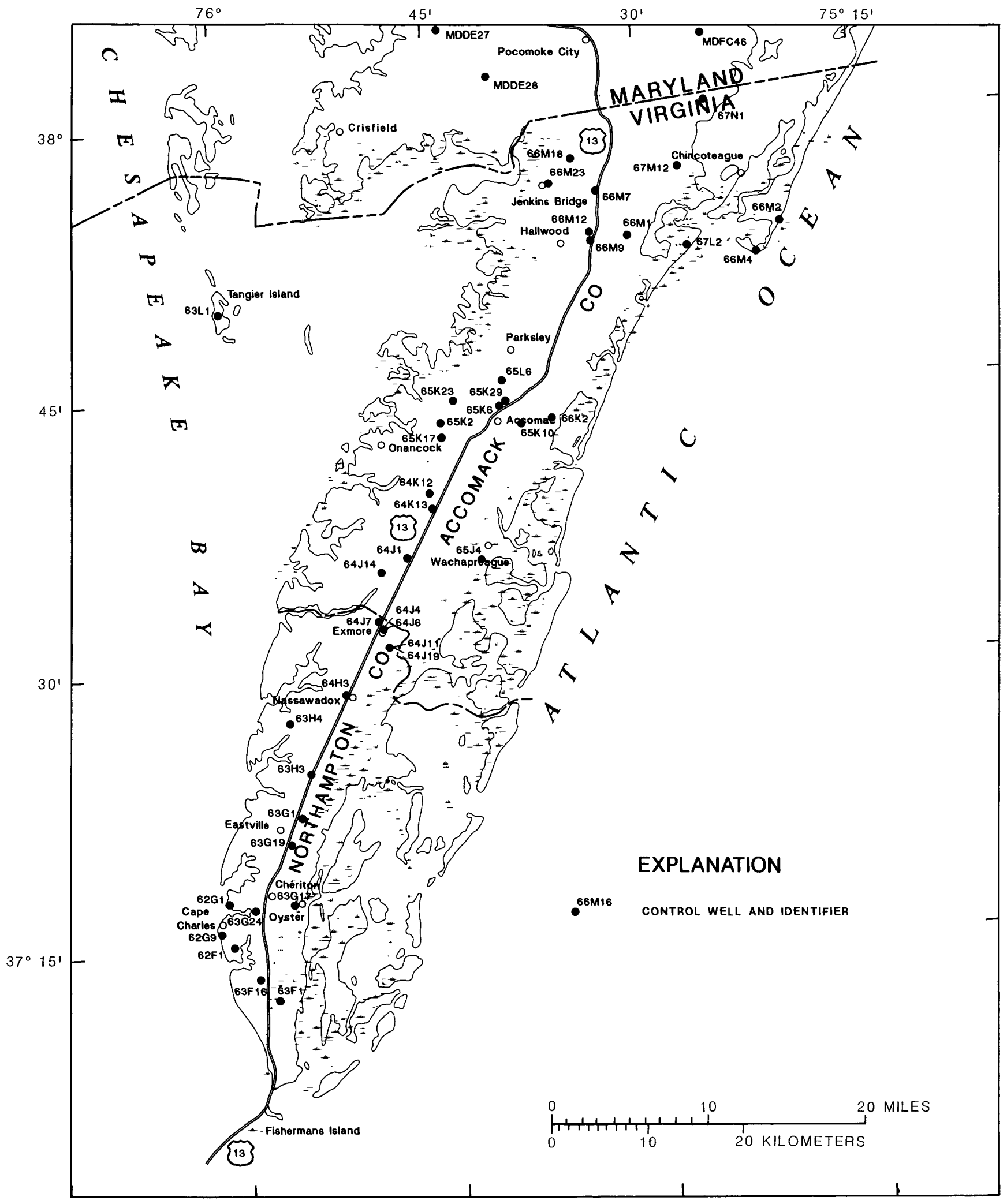

Figure 2. Location of control wells used in hydrogeologic framework analysis. 
below present sea level) or removing the Yorktown Formation. As sea levels rose with the retreat of the glaciers, the incised stream channels were infilled with estuarine and marginal-marine deposits generally of a composition different from the eroded sediments. Mixon (1985) and Colman and Mixon (1988) describe such paleochannels that cut eastward across the peninsula at Cape Charles, Eastville, and Exmore, Va.

The remaining Quaternary sediments were deposited in marginal-marine and estuarine environments. The central uplands of the Eastern Shore are flanked by broad, flat terraces and bordered by linear scarps. Mixon (1985) provides the stratigraphic nomenclature and describes the depositional history of Quaternary sediments on the Eastern Shore. Since the Pleistocene Epoch, sea levels have continued to rise along the margins of the Eastern Shore, and Holocene-age deposits make up the salt-marsh, back-bay, and barrier-island sediments around the peninsula. The thickness of the Quaternary sediments ranges from 40 to $150 \mathrm{ft}$.

\section{Aquifers and Confining Units}

Sediments beneath the Eastern Shore have been divided on the basis of hydrologic properties into a layered sequence of aquifers and intervening confining units. Aquifers consist of sand, gravel, and shell material of sufficient saturated thickness to yield significant quantities of water. Confining units consist of clay and silt that are continuous and of low permeability; confining units yield little water and retard the movement of water. Aquifers commonly contain interbedded clay and silt, whereas confining units commonly contain interbedded sand, gravel, and shell material. An aquifer or confining unit can comprise part of a geologic formation, all of a formation, or a combination of all or parts of adjacent formations.

The hydrogeologic framework of aquifers and confining units on the Eastern Shore has been delineated by correlating lithologic and geophysical logs and by analyzing water-quality and water-level data. The locations and depths of the wells used in this analysis and the altitudes of the tops of aquifers and confining units are given in table 1 . The relative positions of the hydrogeologic units throughout the peninsula are illustrated in the hydrogeologic sections shown in plate 1 . The altitudes of the tops of the aquifers and confining units in the freshwater part of the ground-water-flow system are shown in figures 3-9.

Aquifers beneath the Eastern Shore consist of an unconfined aquifer underlain by a series of confined aquifers and intervening confining units (fig. 10). The Columbia aquifer is the uppermost aquifer and is unconfined. The confined aquifers shallower than approximately $300 \mathrm{ft}$ contain freshwater and are named the upper Yorktown-Eastover, middle Yorktown-Eastover, and lower YorktownEastover aquifers. These freshwater aquifers are the focus of this report. The previously defined

Yorktown-Eastover aquifer (Meng and Harsh, 1988) has been refined for this report and divided into the upper, middle, and lower Yorktown-Eastover aquifers. The Yorktown-Eastover aquifers are underlain by aquifers and confining units that contain salty water (water with chloride concentrations greater than $250 \mathrm{mg} / \mathrm{L})$.

\section{Columbia Aquifer}

The Columbia aquifer is unconfined throughout the Eastern Shore. It is defined as the saturated, chiefly sandy, surficial sediments that overlie the uppermost continuous clay-silt unit (Meng and Harsh, 1988). The Columbia aquifer primarily consists of Pleistocene sediments of the Columbia Group. Holocene sediments, which overlie the Pleistocene deposits around the margin of the Eastern Shore, are not used as a ground-water source and, therefore, are not discussed further in this report. Lithologically, the Columbia aquifer has a large range in composition, depending on the depositional environment of its lithic units. The composition of the Columbia aquifer ranges from very fine silty sands to very coarse and gravelly clean sands, commonly consisting of thin, discontinuous, interbedded clay and silt. Sinnott and Tibbitts (1968) characterize the deposits that compose the Columbia aquifer as chiefly yellow sand and sandy clay, with minor lenses and beds of gravel. The thickness of the Columbia aquifer and the depth to the water table generally vary with topography. Usually, landsurface elevation is proportional to the thickness of the Columbia aquifer and the depth to the water table. Surface expressions of the water table in this aquifer are the ponds and streams throughout the Eastern Shore.

The Columbia aquifer generally supplies sufficient quantities of ground water for domestic 


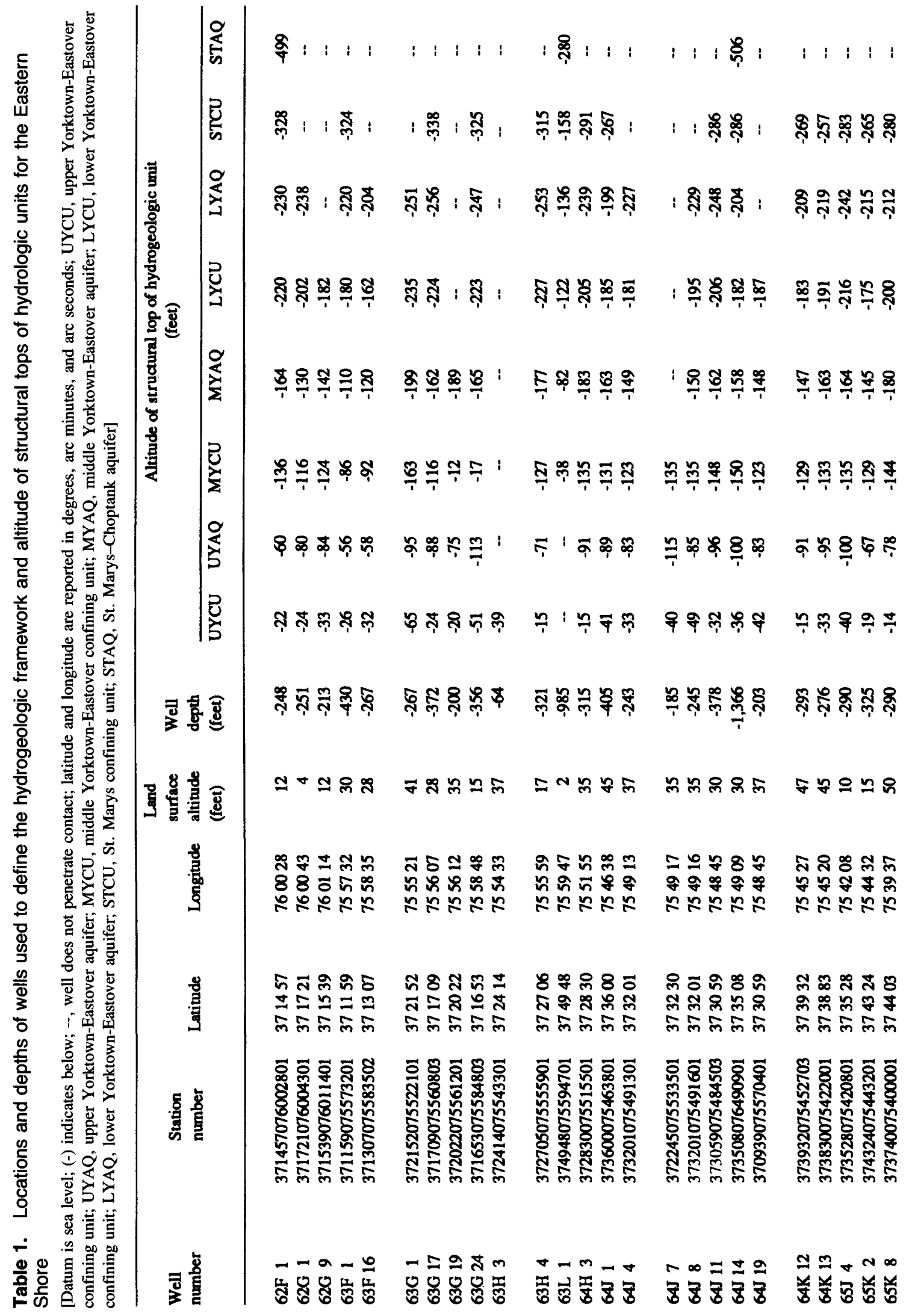




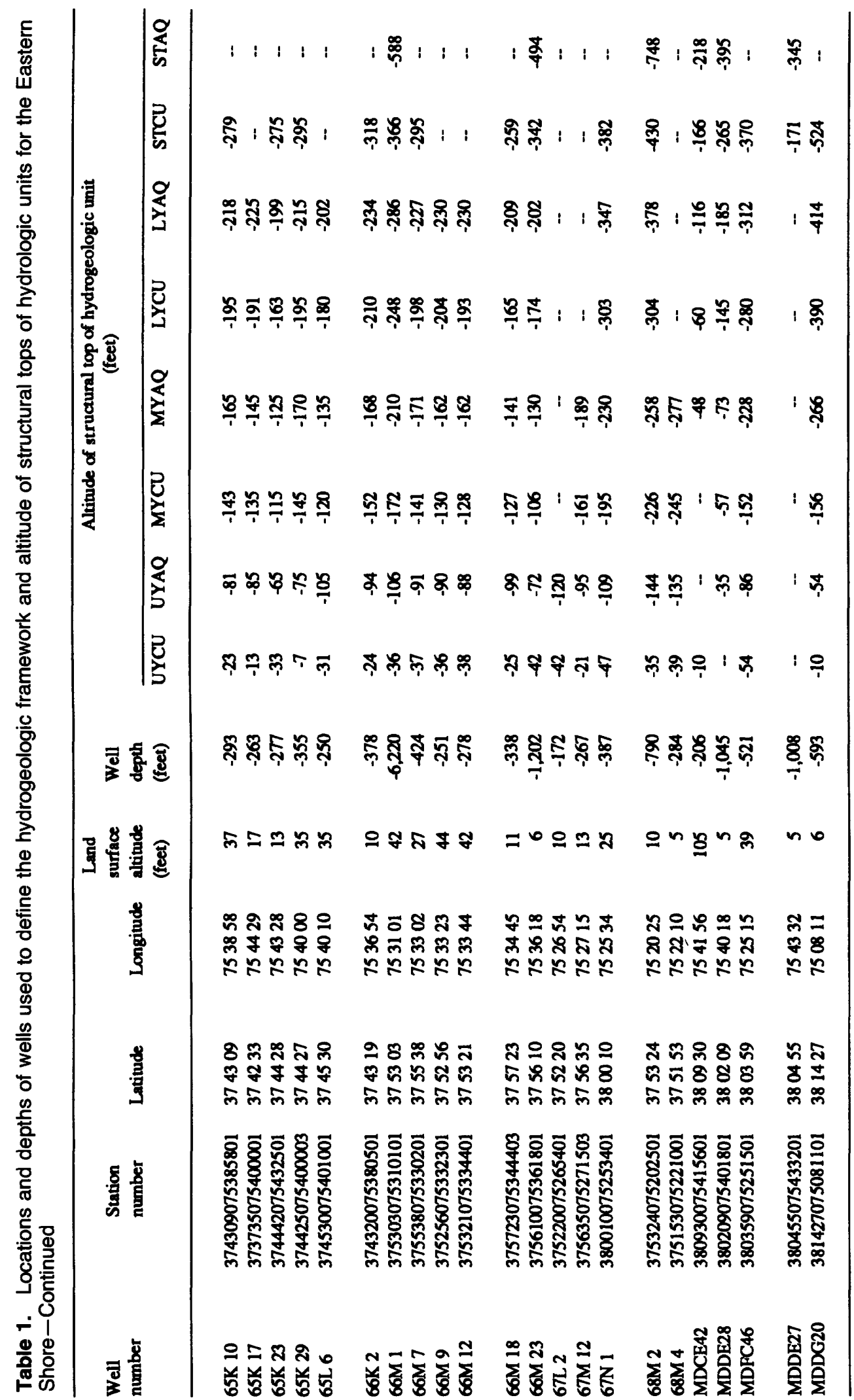




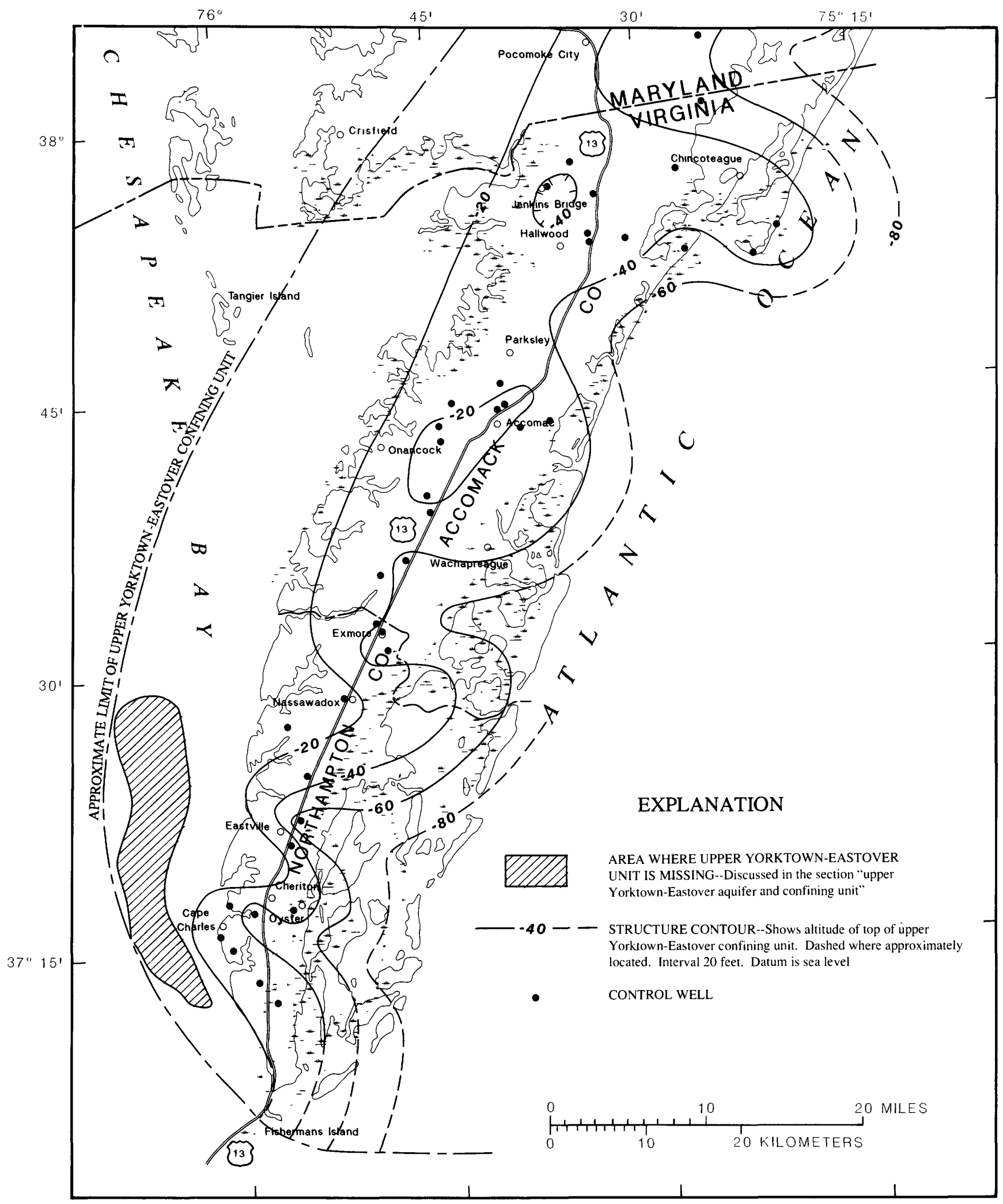

Figure 3. Altitude of top of upper Yorktown-Eastover confining unit. 


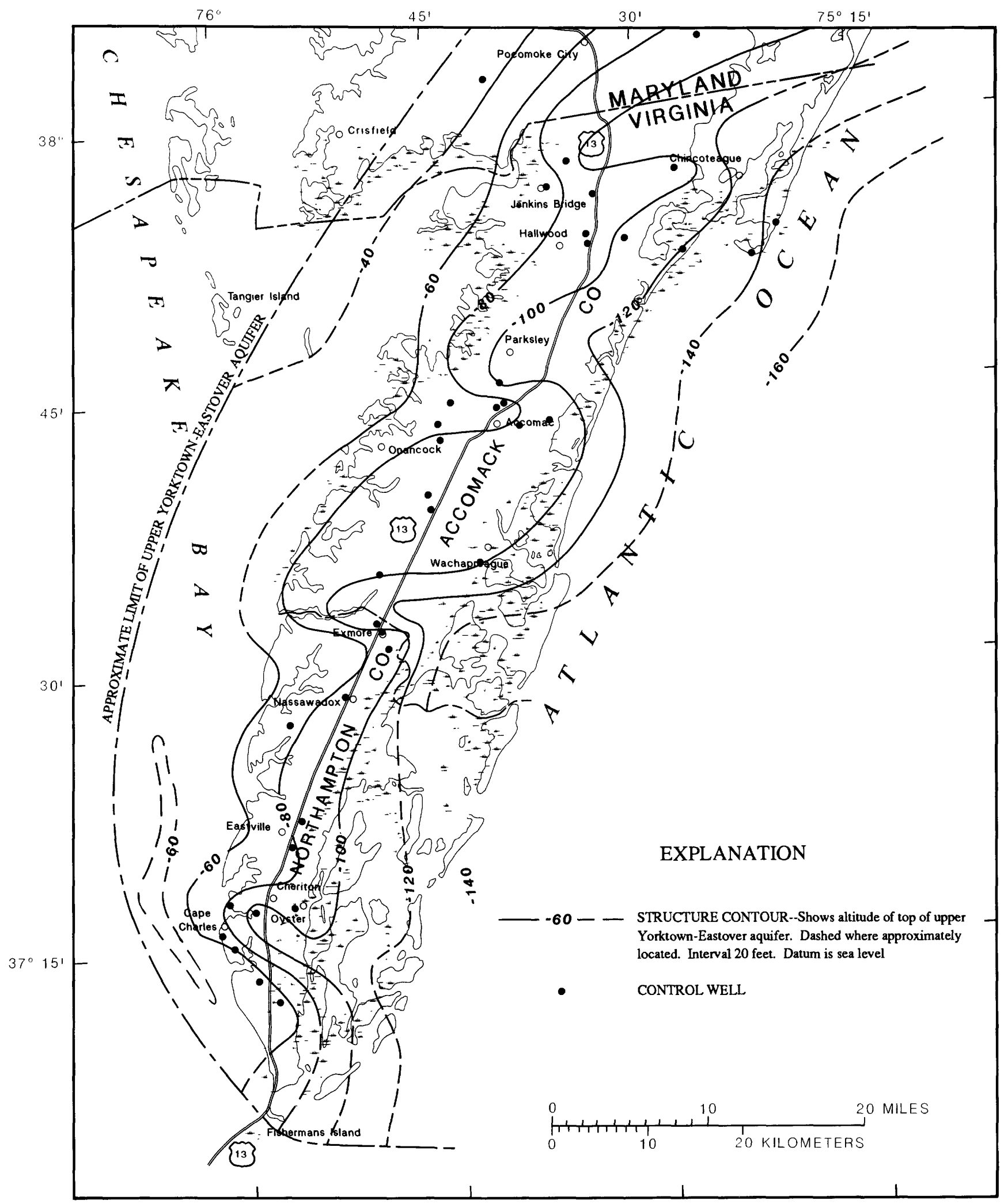

Figure 4. Altitude of top of upper Yorktown-Eastover aquifer. 


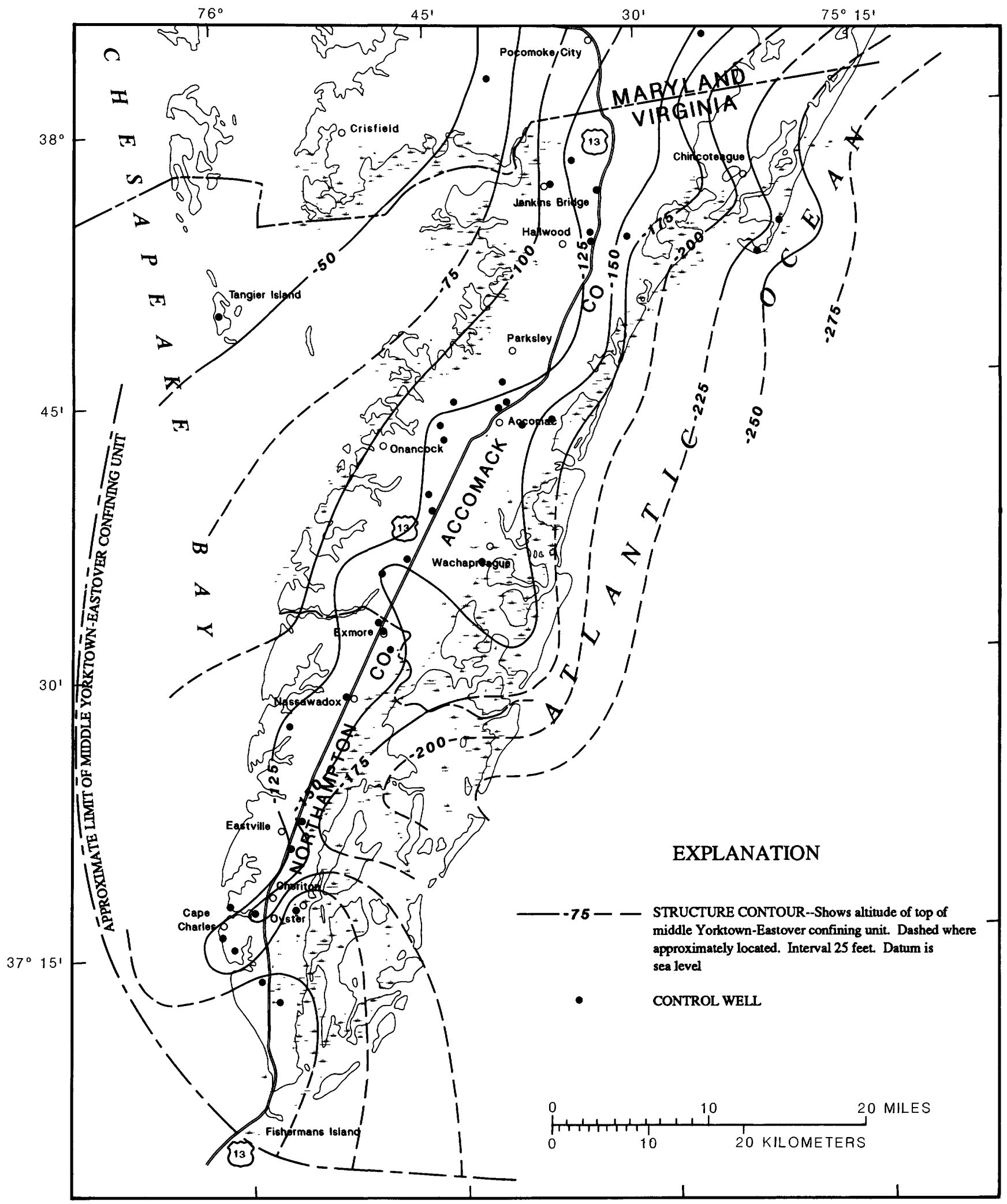

Figure 5. Altitude of top of middle Yorktown-Eastover confining unit. 


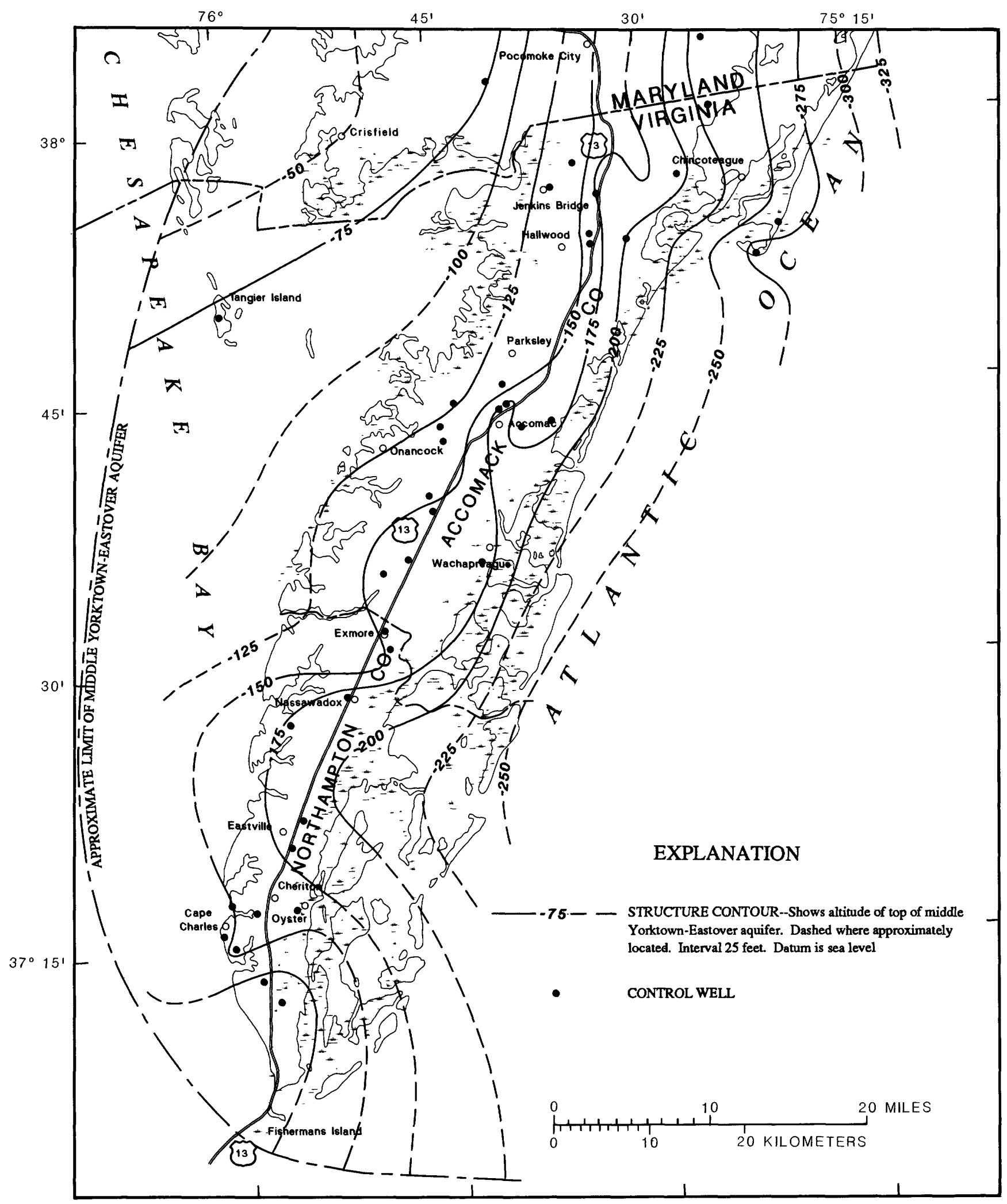

Figure 6. Altitude of top of middle Yorktown-Eastover aquifer. 


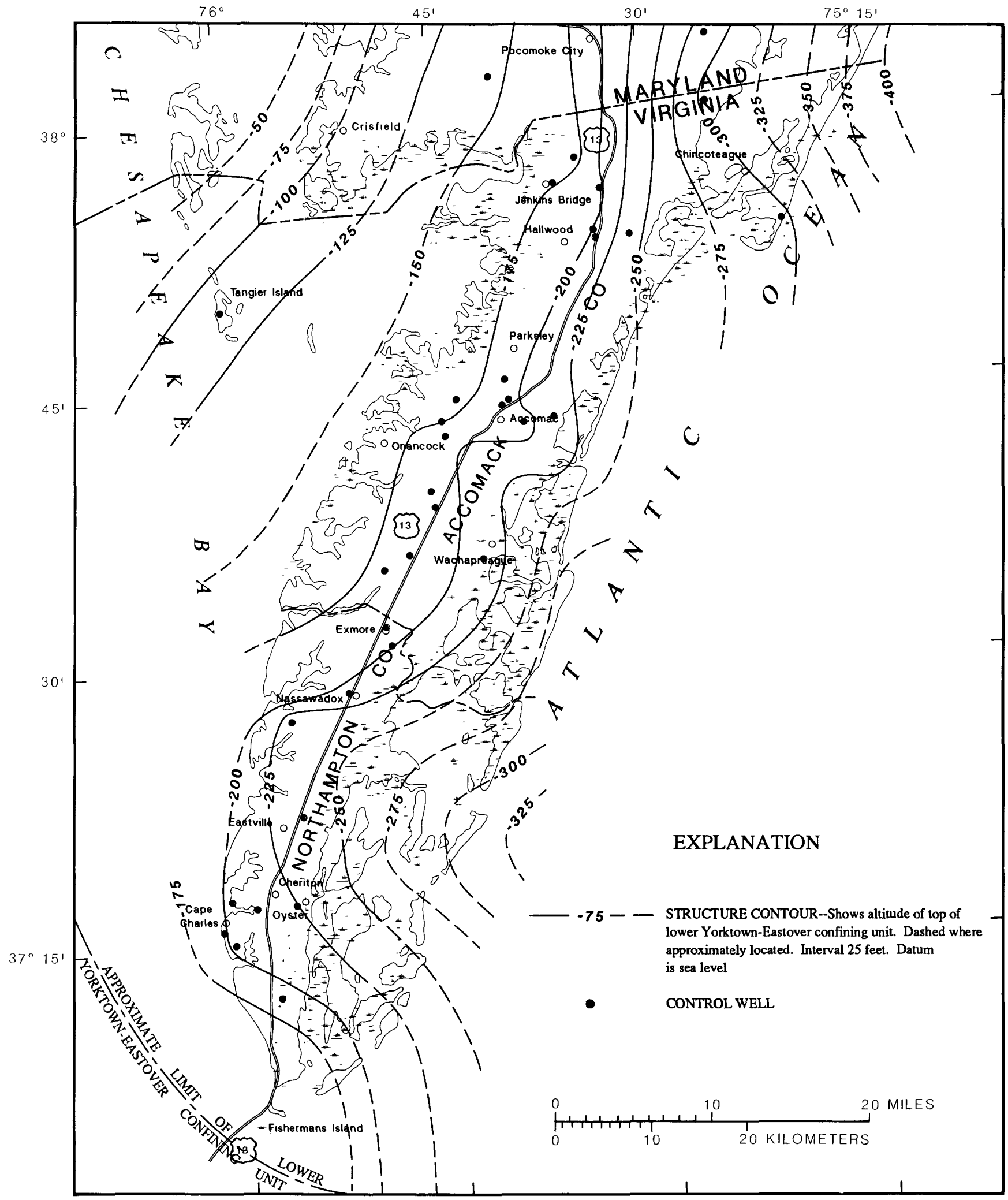

Figure 7. Altitude of top of lower Yorktown-Eastover confining unit. 


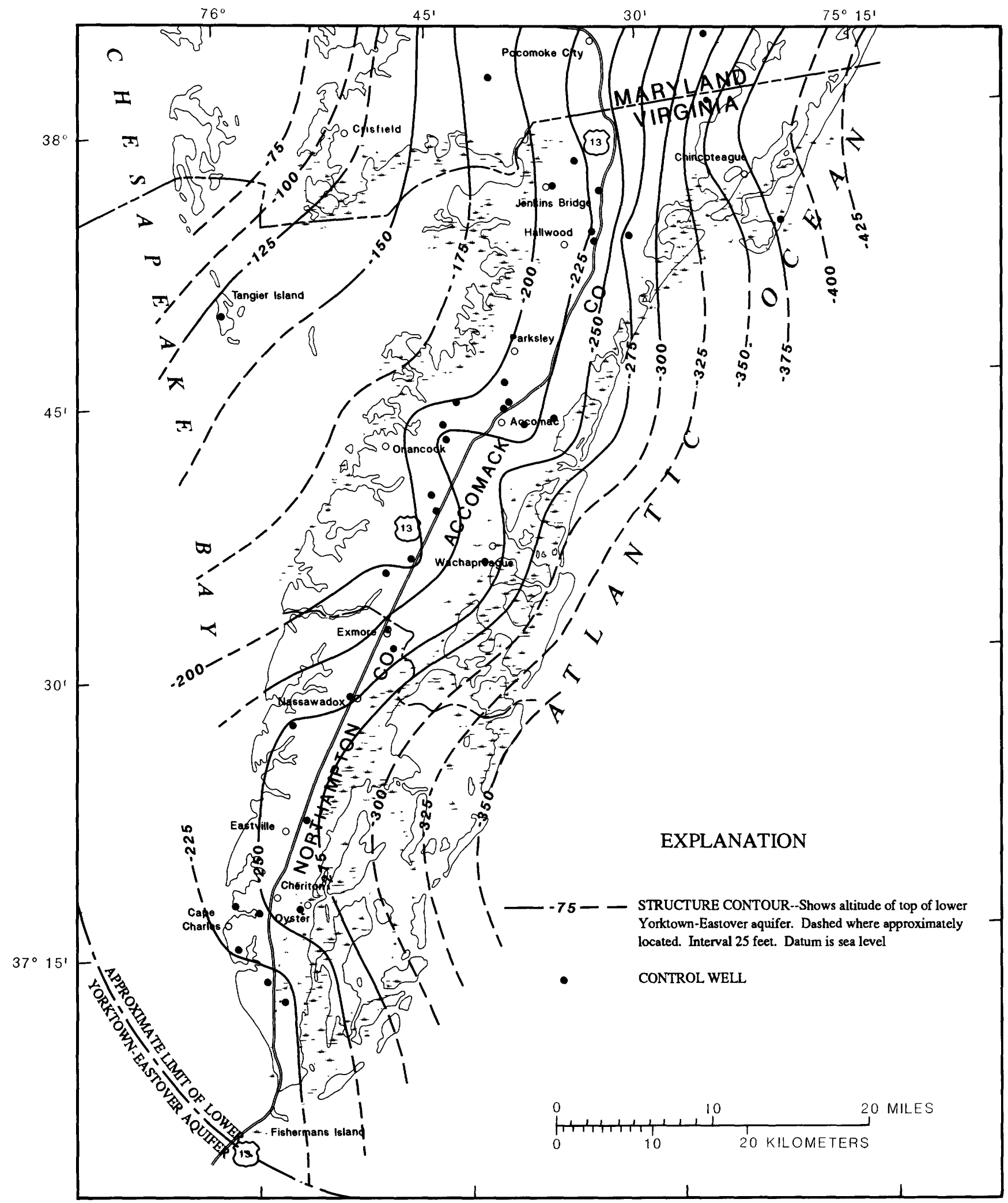

Figure 8. Altitude of top of lower Yorktown-Eastover aquifer. 


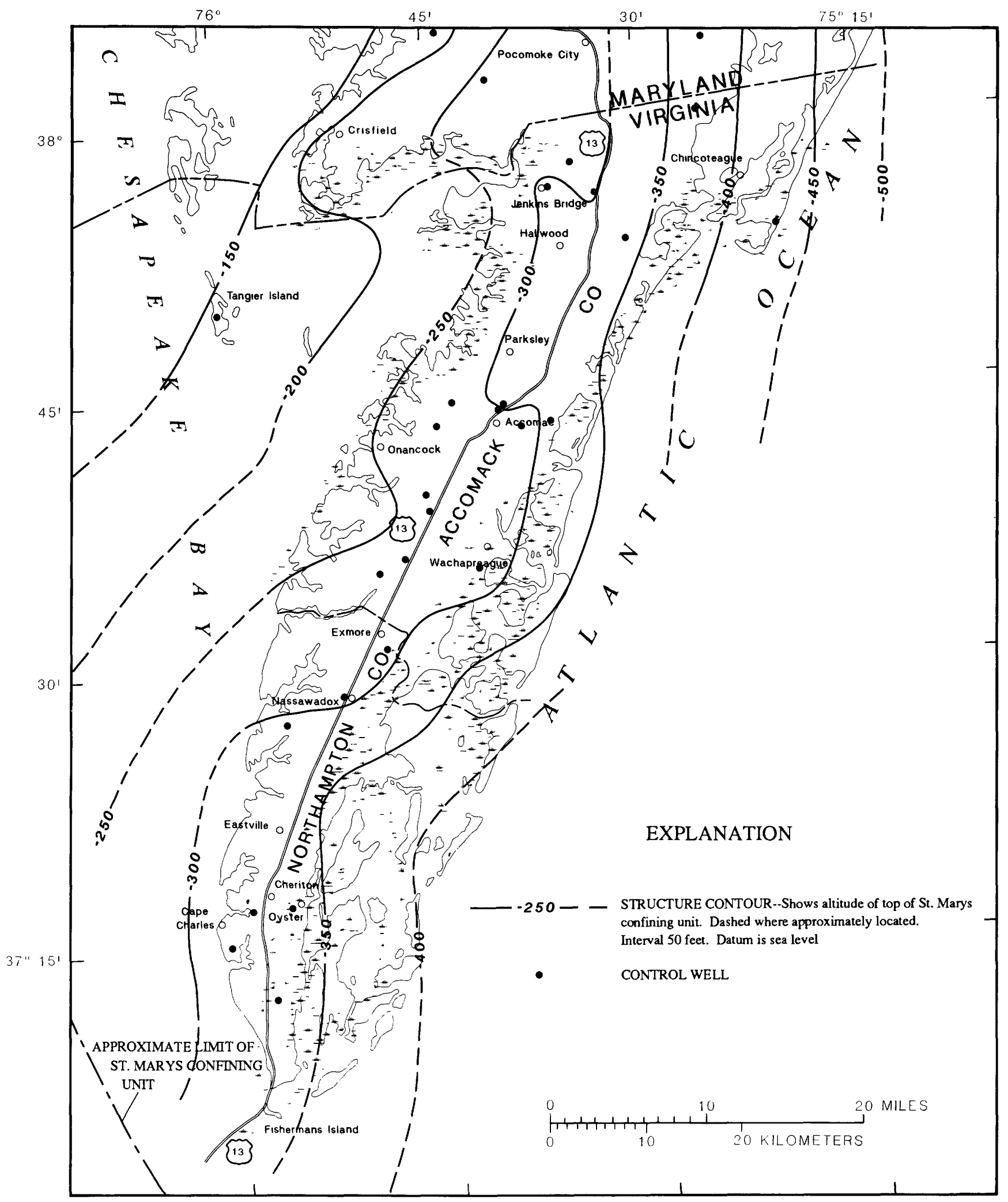

Figure 9. Altitude of top of St. Marys confining unit. 


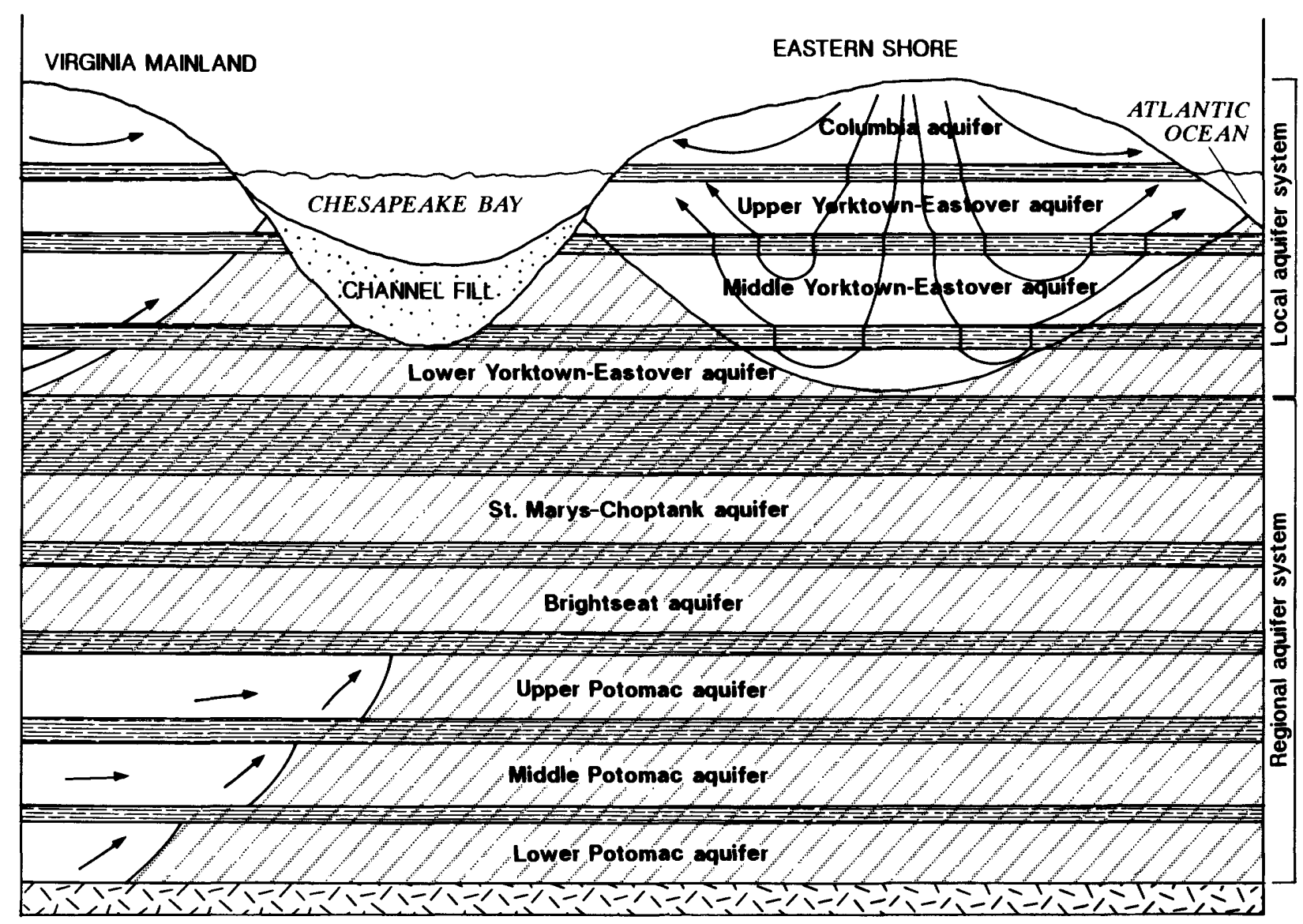

NOT TO SCALE

\section{EXPLANATION}

$\longrightarrow$ GENERALIZED FLOW LINE

$\square$ FRESHWATER

PalTWATER

CONFINING UNIT

TI-Y BASEMENT ROCKS

Figure 10. Schematic diagram of aquifers and confining units and generalized flow lines. 
Table 2. Statistical summary of transmissivity and storage coefficients derived from aquifer-test results $\left[\mathrm{ft}^{2} / \mathrm{d}\right.$, foot squared per day; --, no values reported]

\begin{tabular}{|c|c|c|c|c|c|}
\hline \multirow{3}{*}{$\begin{array}{l}\text { Yorktown- } \\
\text { Eastover } \\
\text { aquifer }\end{array}$} & \multicolumn{5}{|c|}{ Analytical method } \\
\hline & \multicolumn{3}{|c|}{$\begin{array}{l}\text { Nonleaky analysis } \\
\text { of Theis (1935) }\end{array}$} & \multicolumn{2}{|c|}{$\begin{array}{l}\text { Nonleaky analysis of } \\
\text { Cooper and Jacob (1946) }\end{array}$} \\
\hline & $\begin{array}{l}\text { Transmissivit } \\
\left(\mathrm{ft}^{2} / \mathrm{d}\right)\end{array}$ & & $\begin{array}{c}\text { Storage } \\
\text { coefficient } \\
\text { (dimensionless) }\end{array}$ & $\begin{array}{l}\text { Transmissivity } \\
\left(\mathrm{ft}^{2} / \mathrm{d}\right)\end{array}$ & $\begin{array}{l}\text { Storage } \\
\text { coefficient } \\
\text { (dimensionless) }\end{array}$ \\
\hline \multirow[t]{6}{*}{ Upper } & Maximum & 3,960 & $1.3 \times 10^{-3}$ & 670 & $9.5 \times 10^{-4}$ \\
\hline & Minimum & 470 & $2.0 \times 10^{-4}$ & 620 & $4.6 \times 10^{-4}$ \\
\hline & Median & 1,670 & $9.7 \times 10^{-4}$ & - & - \\
\hline & Mean & 1,940 & $8.6 \times 10^{-4}$ & - & - \\
\hline & Number of & & & & \\
\hline & tests & 4 & 4 & 2 & 2 \\
\hline \multirow[t]{6}{*}{ Middle } & Maximum & 2,650 & $8.5 \times 10^{-4}$ & - & - \\
\hline & Minimum & 230 & $9.5 \times 10^{-5}$ & - & - \\
\hline & Median & 1,130 & $5.2 \times 10^{-4}$ & - & - \\
\hline & Mean & 1,290 & $4.9 \times 10^{-4}$ & 350 & $3.8 \times 10^{-4}$ \\
\hline & Number of & & & & \\
\hline & tests & 4 & 4 & 1 & 1 \\
\hline \multirow[t]{6}{*}{ Lower } & Maximum & 1,360 & $9.4 \times 10^{-4}$ & - & - \\
\hline & Minimum & 120 & $2.6 \times 10^{-4}$ & - & - \\
\hline & Median & - & - & - & - \\
\hline & Mean & - & - & - & - \\
\hline & Number of & & & & \\
\hline & tests & 2 & 2 & & \\
\hline
\end{tabular}

purposes. Irrigation ponds in the Columbia aquifer provide much of the water needed for agricultural purposes. In upland areas, the quality of water in this aquifer is generally within drinking-water standards if wells are not located downgradient of potential sources of contamination. In low-lying and poorly drained areas, the water quality is worse than in upland areas, reflecting the nearness of saltwater bodies and contamination from land uses.

\section{Pleistocene Paleochannel Aquifers}

Evidence indicates the presence of subsurface erosional channels where all or part of the Yorktown Formation sediments have been removed and replaced by marginal-marine deposits of Pleistocene age. The sediments in these paleochannel areas are, therefore, quite different from the Yorktown sediments that are typical of the rest of the Eastern Shore. The two major paleochannels that have been identified in the study area cut eastward across the peninsula near Exmore and Eastville, Va. Mixon (1985) describes the lithology of a type cross section in the vicinity of the Eastville paleochannel in southern Northampton County. The channel is covered with a basal-gravelly sand unit that contains pebbles and small cobbles overlain by muddy sand and clay-silt, marginal-marine deposits. The sands and gravels of the channel deposits are extremely transmissive; however, their extent has not yet been defined, and the gravelly sands are overlain by a poorly sorted mixture of mud, silt, and clay of varying thicknesses. Detailed study of the paleochannels is necessary to define the extents of the different types of sediments and determine the hydraulic properties associated with those sediments. For the purposes of this report, the channel sediments are hydraulically connected to the surrounding Yorktown sediments and have been included as part of the Yorktown-Eastover aquifer system.

\section{Yorktown-Eastover Aquifer System}

The Yorktown-Eastover aquifer system is a multiaquifer unit consisting of late Miocene and Pliocene deposits and is composed of the sandy facies of the Yorktown and Eastover Formations (Meng and Harsh, 1988). The Yorktown-Eastover aquifer 
Table 3. Statistical summary of well yield, specific capacity, transmissivity, and horizontal hydraulic conductivity derived from specific-capacity tests

[gal/min, gallon per minute; (gal/min)/ft, gallon per minute per foot; $\mathrm{ft}^{2} / \mathrm{d}$, foot squared per day; $\mathrm{ft} / \mathrm{d}$, foot per day]

\begin{tabular}{|c|c|c|c|c|c|c|c|}
\hline \multirow{2}{*}{$\begin{array}{l}\text { Yorktown- } \\
\text { Eastover } \\
\text { aquifer }\end{array}$} & \multirow[t]{2}{*}{ Statistic } & \multirow{2}{*}{$\begin{array}{l}\text { Well } \\
\text { yield } \\
\text { (gal/min) }\end{array}$} & \multirow{2}{*}{$\begin{array}{l}\text { Specific } \\
\text { capacity } \\
\text { [(gal/min)/ft] }\end{array}$} & \multicolumn{2}{|c|}{$\begin{array}{l}\text { Transmissivity } \\
\left(\mathrm{ft}^{2} / \mathrm{d}\right)\end{array}$} & \multicolumn{2}{|c|}{$\begin{array}{l}\text { Horizontal hydraulic conductivity } \\
\text { (ft/d) }\end{array}$} \\
\hline & & & & Unadjusted & Adjusted $^{1}$ & Unadjusted & Adjusted $^{1}$ \\
\hline \multirow[t]{5}{*}{ Upper } & Maximum & 315 & 17.5 & 1,000 & 4,530 & 17.2 & 60.4 \\
\hline & Minimum & 5 & .2 & 49 & 61 & .9 & 3.3 \\
\hline & Median & 120 & 1.7 & 361 & 739 & 10.3 & 10.6 \\
\hline & Mean & 125 & 2.8 & 446 & 1,259 & 8.9 & 21.3 \\
\hline & Number of tests & 14 & 14 & 10 & 10 & 10 & 10 \\
\hline \multirow[t]{5}{*}{ Middle } & Maximum & 645 & 9.9 & 912 & 3,240 & 15.6 & 44.3 \\
\hline & Minimum & 20 & .7 & 186 & 206 & 3.8 & 4.2 \\
\hline & Median & 95 & 1.5 & 427 & 834 & 6.2 & 17.2 \\
\hline & Mean & 136 & 2.3 & 487 & 1,375 & 8.3 & 22.7 \\
\hline & Number of tests & 12 & 12 & 7 & 7 & 7 & 7 \\
\hline \multirow[t]{5}{*}{ Lower } & Maximum & 201 & 5.7 & 1,697 & 2,094 & 19.6 & 24.2 \\
\hline & Minimum & 1 & .1 & 24 & 95 & .4 & 1.6 \\
\hline & Median & 34 & 1.0 & 209 & 353 & 5.3 & 8.8 \\
\hline & Mean & 53 & 1.8 & 35 & 724 & 7.6 & 10.9 \\
\hline & Number of tests & 10 & 10 & 4 & 4 & 4 & 4 \\
\hline
\end{tabular}

${ }^{1}$ Adjusted for effects of partial penetration.

Table 4. Vertical hydraulic conductivities derived from laboratory analyses of sediment cores from the Jenkins Bridge Research Station

[ft/d, foot per day]

\begin{tabular}{clc}
\hline $\begin{array}{l}\text { Depth of sample } \\
\text { below land surface } \\
\text { (feet) }\end{array}$ & Confining unit & $\begin{array}{c}\text { Vertical hydraulic } \\
\text { conductivity } \\
\text { (ft/d) }\end{array}$ \\
\hline $63.7-64.7$ & Upper Yorktown-Eastover & $1.39 \times 10^{-5}$ \\
$348.7-349.7$ & St. Marys & $1.63 \times 10^{-5}$ \\
$368.4-369.4$ & St. Marys & $1.27 \times 10^{-5}$ \\
\hline
\end{tabular}

system consists of a series of alternating sand and clay-silt units that form three distinct aquifers that generally are present throughout the Eastern Shore. These aquifers are identified as the upper, middle, and lower Yorktown-Eastover aquifers. Correspondingly, each aquifer is overlain by the upper, middle, and lower Yorktown-Eastover confining units. The entire aquifer system is wedge shaped and thickens and dips eastward. The units extend eastward beneath the Atlantic Ocean to the continental shelf and westward underneath the Chesapeake Bay.

The hydraulic characteristics of the aquifers and confining units determine their ability to store, transmit, and release water. Transmissivity, storage coefficient, and vertical hydraulic conductivity are the principal hydraulic characteristics necessary for an analysis of ground-water flow. Transmissivities and storage coefficients derived from aquifer-test data for the freshwater-confined aquifers are summarized in table 2 . Few aquifer tests are available that reflect the characteristics of an individual aquifer because most of the wells used for aquifer tests have screens that are open to more than one aquifer. The aquifer-test data are supplemented by transmissivities estimated from specific-capacity data (table 3 ). Table 3 provides a statistical summary of well yield, specific capacity, transmissivity, and horizontal hydraulic conductivity estimated from specificcapacity tests. A detailed description of the method and equations used to estimate transmissivities from specific-capacity data is presented by Laczniak and Meng (1988). A few point estimates for vertical hydraulic conductivities are available from laboratory analysis of sediment cores from the Jenkins Bridge Research Station (well 66M23) (table 4). These data need to be interpreted and used with caution because (1) the core samples could be disturbed, (2) the core samples represent 1-ft intervals of thicker confining units, and (3) the values are local point values and cannot be interpreted as regional estimates. 
Upper Yorktown-Eastover Aquifer and Confining Unit

The Columbia aquifer is underlain by the upper Yorktown-Eastover confining unit. The confining unit consists of gray, greenish-gray, or brownish-gray clayey silt or silty clay. The confining unit is continuous underneath the peninsula; however, incisement by present-day channels in the Chesapeake Bay has likely removed part or all of the upper Yorktown-Eastover confining-unit sediments (figs. 3 and 11) west of the peninsula. In the model area where control wells exist, the confining unit ranges in thickness from $26 \mathrm{ft}$ at well $63 \mathrm{~F} 16$ in southern Northampton County to $109 \mathrm{ft}$ at well $68 \mathrm{M} 2$ on Chincoteague Island. A laboratory analysis of a sediment core from well $66 \mathrm{M} 23$ indicates a vertical hydraulic conductivity of $1.39 \times 10^{-5} \mathrm{ft} / \mathrm{d}$ for the upper Yorktown-Eastover confining unit. Analyses of cores from the St. Marys confining unit, at the same site, indicated similar values (table 4). Elsewhere on the mainland part of the Virginia Coastal Plain, laboratory analyses of confining-unit sediments have ranged from $3.93 \times 10^{-3}$ to $9.2 \times$ $10^{-1} \mathrm{ft} / \mathrm{d}$ (Harsh and Laczniak, 1986).

The upper Yorktown-Eastover confining unit is underlain by the upper Yorktown-Eastover aquifer (figs. 3,4). Geologic data from the Exmore core (well 64J14) and the VWCB Jenkins Bridge Research Station (well 66M23) indicate that the upper Yorktown-Eastover aquifer predominantly consists of Yorktown Formation (Pliocene) sediments. Lithologically, the sediments of the Yorktown are diverse, consisting of varying mixtures of fine-grained to very coarse-grained, white to greenish-gray, shelly, glauconitic, and pebbly quartz sands (Meng and Harsh, 1988). Hydraulic properties of the upper Yorktown-Eastover aquifer are summarized in tables 2 and 3. The range of fine-grained to very coarse-grained sediments in the Yorktown Formation and the variable aquifer thickness result in an order of magnitude range in transmissivity values. The upper Yorktown-Eastover aquifer extends eastward to the continental shelf and westward underneath the Chesapeake Bay. The characteristics and extent of the upper Yorktown-Eastover aquifer are not known in offshore areas beneath the Atlantic Ocean and the Chesapeake Bay. The upper Yorktown-Eastover aquifer is most likely truncated beneath the Chesapeake Bay by erosion from the ancient Susquehanna River channel and incised by the nearshore channels of the present-day Chesa- peake Bay (Hack, 1957; Colman and others, 1990). In the model area where control wells exist, the upper Yorktown-Eastover aquifer ranges in thickness from $15 \mathrm{ft}$ at well $65 \mathrm{~L} 6$ in central Accomack County to $110 \mathrm{ft}$ at well $68 \mathrm{M} 4$ on Chincoteague Island.

\section{Middle Yorktown-Eastover Aquifer and Confining Unit}

The upper Yorktown-Eastover aquifer is underlain by the middle Yorktown-Eastover confining unit. The confining unit consists of gray, greenish-gray, or brownish-gray clayey silt or silty clay and ranges in thickness from $8 \mathrm{ft}$ at well 63G24 in southern Northampton County to $76 \mathrm{ft}$ at well MDFC46 in Worcester County, Md. The confining unit is present throughout the study area.

The middle Yorktown-Eastover confining unit is underlain by the middle Yorktown-Eastover aquifer. Estimated hydraulic properties are summarized in tables 2 and 3. The middle Yorktown-Eastover aquifer consists of sediments from the Yorktown Formation; therefore, the hydraulic properties of the middle Yorktown-Eastover aquifer are similar to those of the upper Yorktown-Eastover aquifer. The middle Yorktown-Eastover aquifer is present throughout the study area. The characteristics and extents of these units in offshore areas are unknown. It is likely that the western limit of the middle Yorktown-Eastover aquifer (fig. 6) extends beyond the western limit of the upper Yorktown-Eastover aquifer (fig. 4) as a result of erosion by the ancient Susquehanna River channel. In the model area, where control wells exist, the middle YorktownEastover aquifer ranges in thickness from $12 \mathrm{ft}$ at well MDCE42 in Somerset County, Md., to $124 \mathrm{ft}$ at well $67 \mathrm{~N} 1$ in northeastern Accomack County.

\section{Lower Yorktown-Eastover Aquifer and Confining Unit}

The middle Yorktown-Eastover aquifer is underlain by the lower Yorktown-Eastover confining unit. The lithology of the confining unit is similar to that of the middle and upper confining units and consists of gray, greenish-gray, or brownish-gray clayey silt or silty clay. The lower YorktownEastover confining unit ranges in thickness from 10 $\mathrm{ft}$ at well $62 \mathrm{~F} 1$ in southern Northampton County to $74 \mathrm{ft}$ at well 68M2 on Chincoteague Island (fig. 2).

The lower Yorktown-Eastover aquifer underlies the lower Yorktown-Eastover confining unit and primarily consists of sediments from the Miocene 


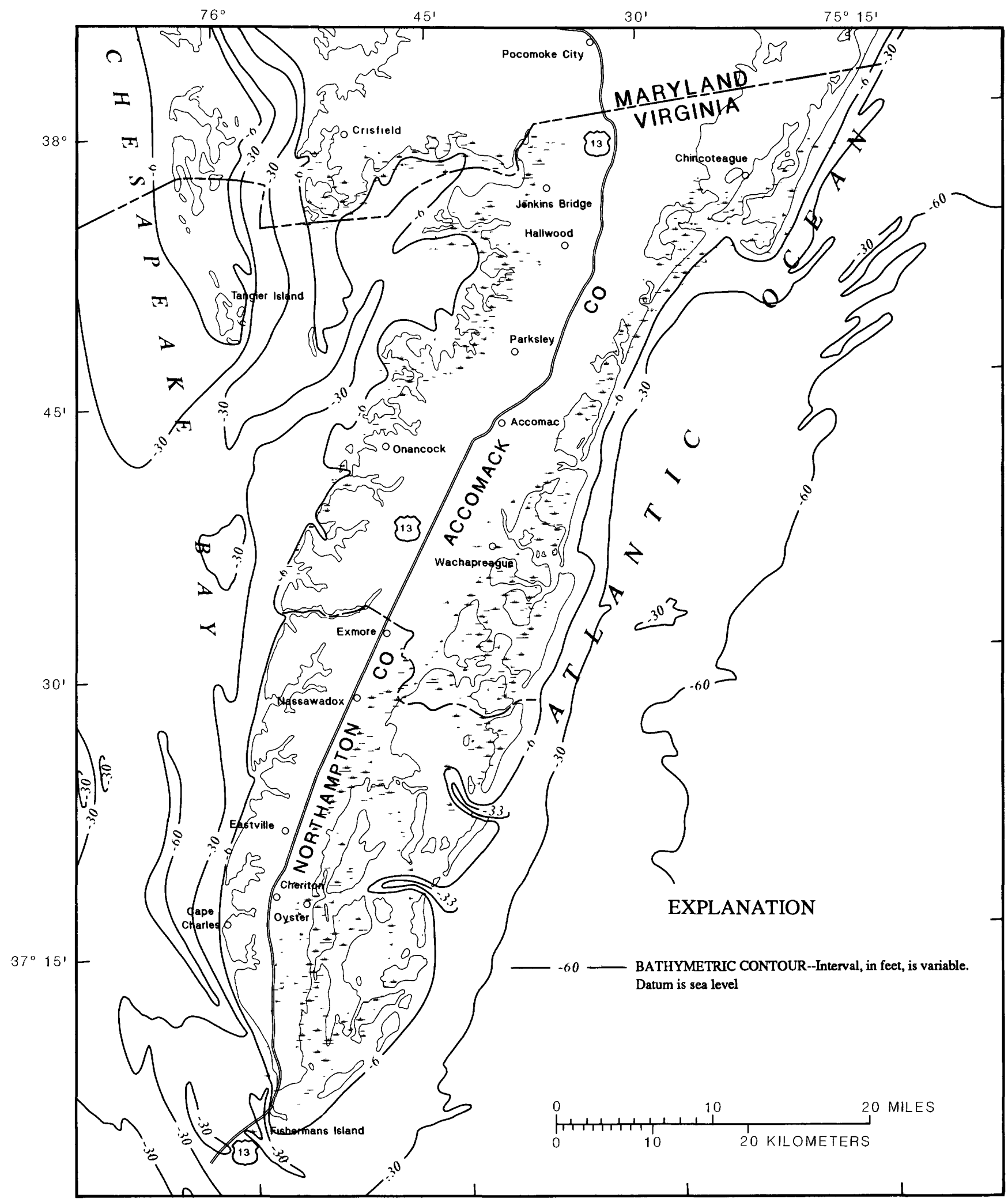

Figure 11. Bathymetry in the vicinity of the Eastern Shore. 
Eastover Formation. Mixon (1985) describes the Eastover sediments as chiefly fine-grained to very fine-grained, greenish-gray, clayey, silty, and shelly quartz sands. Estimated hydraulic properties of the lower Yorktown-Eastover aquifer are summarized in tables 2 and 3 . The Eastover Formation typically contains finer-grained sediments than the Yorktown Formation; therefore, the lower Yorktown-Eastover aquifer generally is less transmissive than the upper and middle Yorktown-Eastover aquifers. The lower Yorktown-Eastover aquifer is present throughout the study area. Because the lower Yorktown-Eastover aquifer is at a greater depth, its limit probably extends farther west underneath the Chesapeake Bay than the middle and upper Yorktown-Eastover aquifers (figs. 4, 6, and 8). The lower YorktownEastover aquifer ranges in thickness from $22 \mathrm{ft}$ at well $63 \mathrm{Ll}$ on Tangier Island (fig. 2) to $140 \mathrm{ft}$ at well 66M23 in Accomack County.

\section{St. Marys Confining Unit}

The St. Marys confining unit consists of the predominantly clayey facies of the St. Marys Formation and the lower clayey facies of the Eastover Formation. These sediments are middle to late Miocene in age. The St. Marys confining unit is conformably overlain throughout the study area by the lower Yorktown-Eastover aquifer. The sediments consist of interbedded silty and sandy clay and varying amounts of shells, typically bluish-gray to gray in color (Meng and Harsh, 1988). Laboratory analyses of sediment cores from the St. Marys confining unit at well 66M23 indicate vertical hydraulic conductivities of $1.63 \times 10^{-5}$ and $1.27 \times 10^{-5} \mathrm{ft} / \mathrm{d}$ (table 4). The St. Marys confining unit ranges in thickness from 150 to $350 \mathrm{ft}$. This massive clay unit is effectively a lower boundary for the fresh groundwater-flow system on the Eastern Shore.

\section{Ground-Water Hydrology}

The ground-water-flow system can be divided into a local and a regional ground-water-flow system (fig. 10). The local ground-water-flow system consists of the unconfined aquifer (Columbia) and the confined-freshwater aquifers (upper, middle, and lower Yorktown-Eastover). The aquifers in the local system contain freshwater that is recharged locally by rainfall on the Eastern Shore and discharges locally to estuaries, marshes, the Chesapeake Bay, and the Atlantic Ocean. The regional system of the Eastern Shore consists of the confined aquifers beneath the lower Yorktown-Eastover aquifer. Information for these deep confined aquifers beneath the Eastern Shore is limited; however, it is likely that the lower Yorktown-Eastover aquifer is underlain by the St. Marys-Choptank, Brightseat, upper Potomac, middle Potomac, and lower Potomac aquifers (Meng and Harsh, 1988). These aquifers are hydraulically separated from the overlying freshwater aquifers by the thick St. Marys confining unit. The regional aquifers are continuous underneath the Chesapeake Bay, and deep ground-water-flow beneath the Eastern Shore is affected by the regional Coastal Plain ground-water-flow system.

\section{Local Ground-Water-Flow System}

A schematic of ground-water flow in the local ground-water system is presented in figure 10 . Freshwater recharges the local ground-water system primarily through precipitation that falls on the peninsula and infiltrates into the sediments, because there are no major surface-water bodies on the peninsula. Cushing and others (1973) estimated that 8.5 to $15 \mathrm{in}$. of the $43 \mathrm{in}$. of annual precipitation recharges the unconfined aquifer; the remainder is either surface runoff or evaporation. Using an average recharge of 12 inches per year (in/yr) over a 450 square mile $\left(\mathrm{mi}^{2}\right)$ recharge area (total land area minus wetlands) for the Virginia part of the Eastern Shore, the estimated natural recharge to the unconfined aquifer is $257 \mathrm{Mgal} / \mathrm{d}$. Precipitation infiltrates into the ground and percolates to the water table of the Columbia aquifer. Water in the unconfined aquifer flows vertically into the lower parts of the unconfined aquifer and laterally through the unconfined aquifer toward discharge sites such as springs, streams, marshes, estuaries, the Chesapeake Bay, and the Atlantic Ocean. The lateral direction of ground-water flow generally is from the groundwater divide at the center of the peninsula to the Chesapeake Bay and Atlantic Ocean. Eventually, water that is moving vertically encounters the upper Yorktown-Eastover confining unit, and much of the flow is forced to move laterally through the unconfined aquifer. Under natural (prepumping) conditions, a comparatively small amount of water is able to flow through the less permeable confining unit into the confined-aquifer system. The predominant movement of ground water is in a lateral direction 
through aquifers and in a vertical direction through confining units. Where fresh ground water encounters salty ground water, the less dense freshwater is forced upward. The upward-moving fresh ground water is again inhibited by confining units but eventually discharges into marshes, estuaries, the bay, and ocean.

Water levels in wells in the Columbia aquifer indicate the direction of ground-water flow and the response of the system to recharge and discharge. Well-construction information for wells along a transect from the topographic high (ground-water divide) near U.S. Route 13 near Townsend, Va., to the marsh adjacent to Magothy Bay (ground-waterdischarge area) (fig. 12) is presented in table 5. Water levels fluctuate throughout the year in response to the amount of recharge to and discharge from the system (fig. 13). Water-level declines in this agricultural area during the spring and summer indicate the effects of increased evapotranspiration. Water levels are highest at well 63F31 near the center of the peninsula and decline toward the coast (fig. 13). The water-level gradients indicate that ground water flows from the topographic high in the center of the peninsula to the lowlands adjacent to Magothy Bay. Water levels from an irrigation pond (63F38) and a nearby well (63F31) show the response of the unconfined aquifer to pumping (fig. 14). The water level in well $63 \mathrm{~F} 31$ shows little response to the greater than 4 -ft decline in water levels in the pond caused by pumpage during the 1989 growing season. Pumpage from the irrigation pond only has a local effect on ground-water levels because of the high permeability of the coarsegrained sediments in the unconfined aquifer.

Temporal water-level trends and vertical gradients in water levels provide additional information about the response of the ground-water-flow system to recharge, discharge, and pumpage stress. The VWCB has constructed a series of research stations on the Eastern Shore to monitor such responses (fig. 15). Each research station consists of a cluster of wells with individual wells screened in different aquifers. Well identifiers, well location, and wellconstruction information for wells in selected research stations are summarized in table 6 . Water levels from research-station wells provide information about the vertical direction of flow between aquifers. Water levels for two research stations on the Eastern Shore that illustrate the vertical directions of flow in this multiaquifer system are shown
Table 5. Well-construction data for wells completed in the Columbia aquifer in a transect $A-A^{\prime}$ near Townsend, $\mathrm{Va}$.

[Datum is sea level; well depth is in feet below land surface datum; USGS, U.S. Geological Survey]

\begin{tabular}{llcc}
\hline $\begin{array}{l}\text { USGS } \\
\text { well } \\
\text { number }\end{array}$ & $\begin{array}{l}\text { Station } \\
\text { number }\end{array}$ & $\begin{array}{l}\text { Land-surface } \\
\text { elevation } \\
\text { (feet) }\end{array}$ & $\begin{array}{c}\text { Well } \\
\text { depth } \\
\text { (feet) }\end{array}$ \\
\hline 63F 25 & 371145075565901 & 12.38 & 6.6 \\
63F 26 & 371143075565801 & 15.37 & 8.9 \\
63F 27 & 371133075570401 & 22.92 & 12.7 \\
63F 29 & 371121075565001 & 13.40 & 9.5 \\
63F 30 & 371128075572101 & 29.03 & 15.0 \\
63F 31 & 371136075580201 & 31.79 & 12.0 \\
63F 32 & 371136075574801 & 28.95 & 12.0 \\
63F 38 & 371144075580201 & 22.00 & pond \\
63F 49 & 371125075570205 & 27.35 & 16.8 \\
\hline
\end{tabular}

in figure 16. The water levels for the research station in a recharge area (fig. 16A) reflect downward vertical flow from the unconfined aquifer (well $64 \mathrm{~K} 10$ ), to the upper Yorktown-Eastover aquifer (well 64K11), to the lower Yorktown-Eastover aquifer (well 64K12). In contrast, the water levels presented in figure $16 \mathrm{~B}$ indicate upward flow in a coastal discharge area. Well $64 \mathrm{~J} 11$ is screened in the lower Yorktown-Eastover aquifer, whereas wells 64J10 and 64J9 are screened in the middle and upper Yorktown-Eastover aquifers, respectively. Except for the early period of record when water levels appear to be affected by pumping, heads in the wells for this research station reflect vertical flow in an upward direction as ground water flows toward discharge sites in the coastal marshes, estuaries, and ocean.

\section{Regional Ground-Water-Flow System}

The regional ground-water-flow system consists of the confined aquifers beneath the lower Yorktown-Eastover aquifer (fig. 10). These aquifers are continuous underneath the Chesapeake Bay and are part of the westward-thinning wedge of unconsolidated sediments that make up the Coastal Plain of Virginia. Ground-water flow in these deep confined aquifers beneath the Eastern Shore is affected by the Chesapeake Bay and regional ground-water flow from the Virginia mainland. Freshwater is recharged to the deep confined aquifers from precipitation that falls on the Virginia mainland and infiltrates into the confined system. At the northern end of the peninsula, fresh ground water flows farther beneath the Chesapeake Bay and the Eastern Shore 


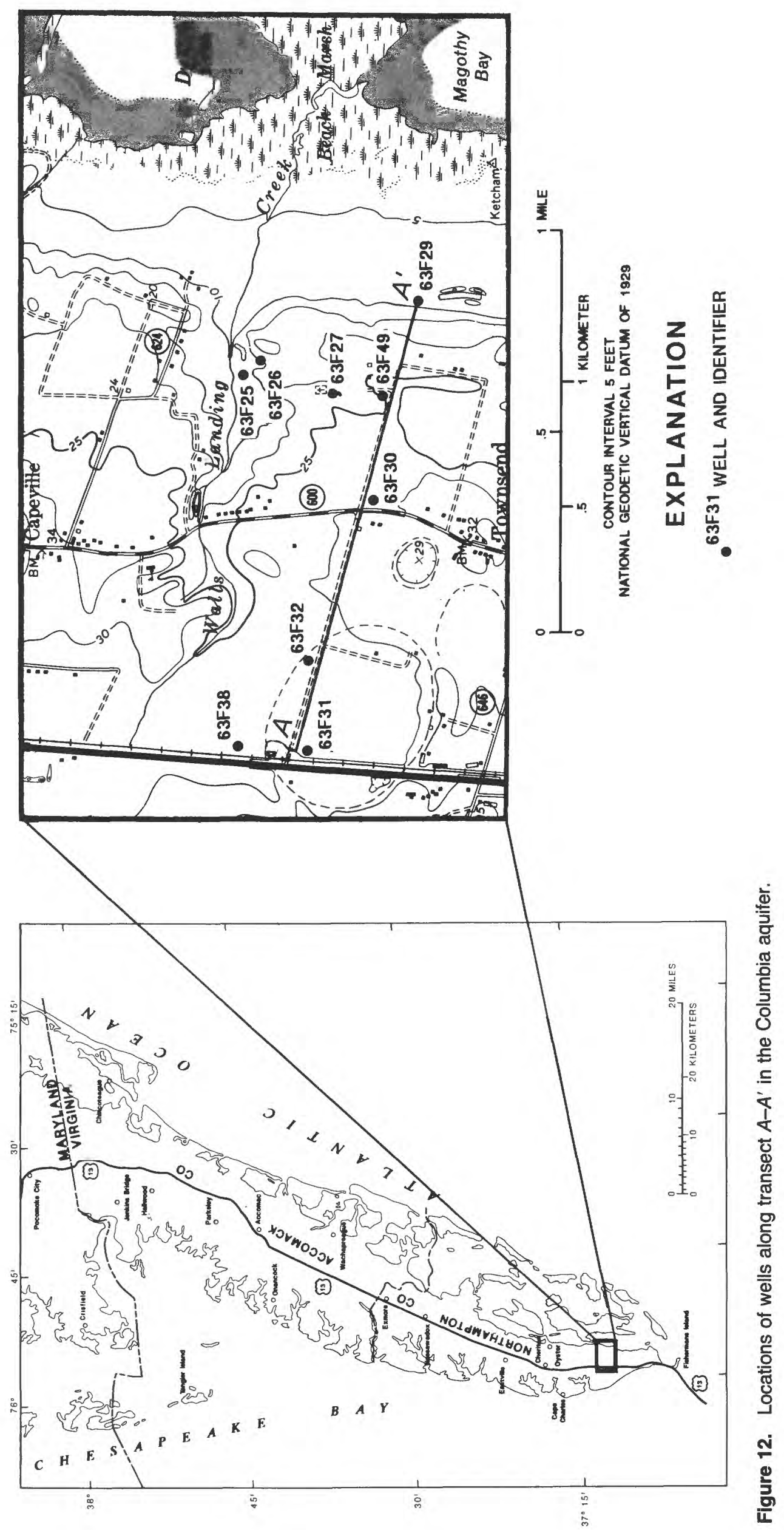




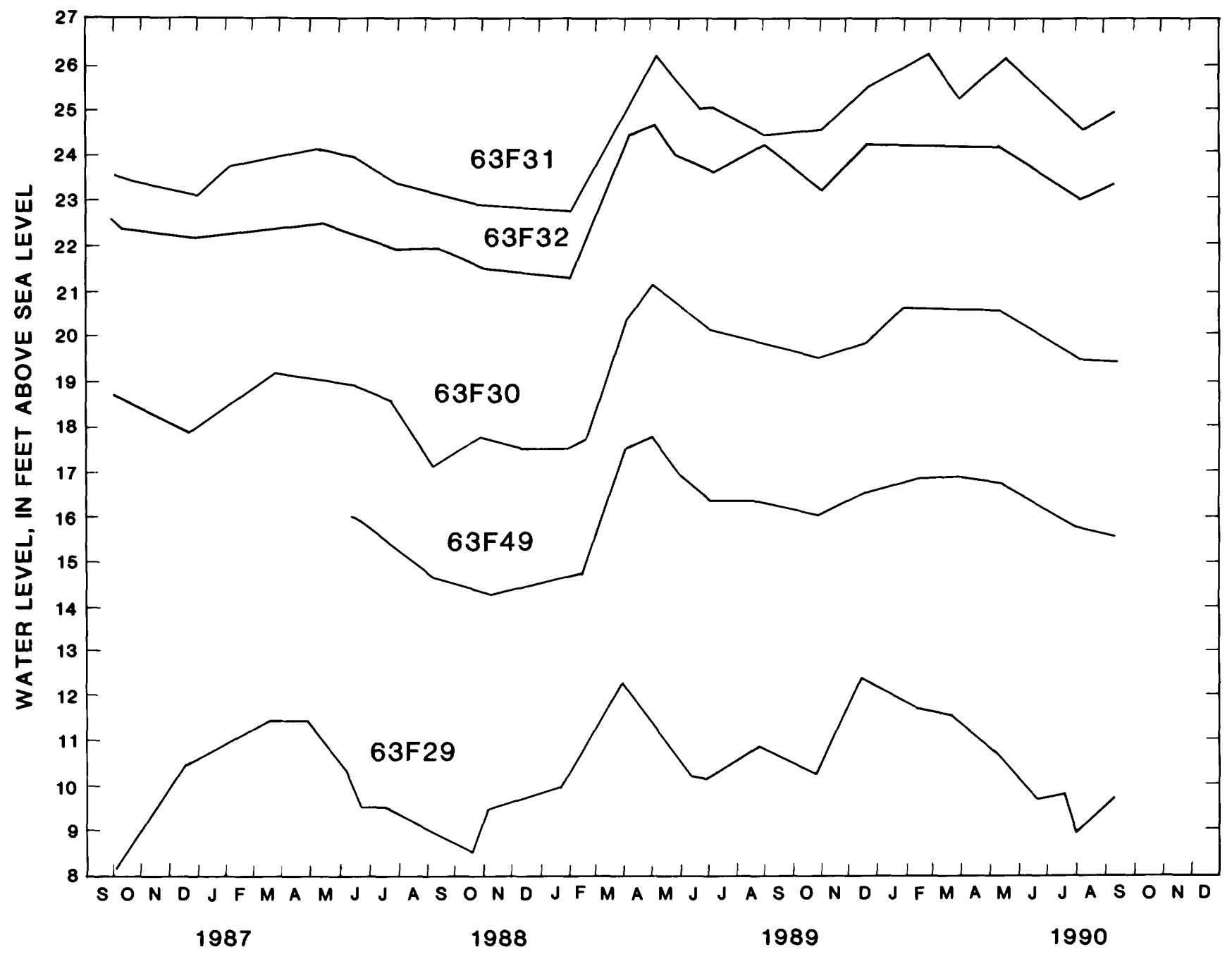

Figure 13. Water levels in selected wells along transect $A-A^{\prime}$ in the Columbia aquifer.

than at the southern end. The northern end of the peninsula is closer to higher landmasses; therefore, it has a nearby freshwater source. The freshwater heads at the southern part of the Virginia Coastal Plain are not high enough to force the saltwater out of the deep sediments beneath the Chesapeake Bay and Eastern Shore.

Chloride concentrations support this conceptualization of ground-water flow. Chloride concentrations in ground water from the upper Potomac aquifer for the Virginia Coastal Plain are lower along the coast in the northeastern part of the Virginia mainland than in the southeastern part (fig. 17). The chloride concentration is $150 \mathrm{mg} / \mathrm{L}$ in water from well 63L4 on Tangier Island, which is screened in the upper Potomac aquifer. Chloride concentrations in water from wells at approximately the same longitude in the southeastern part of the Virginia mainland range from 1,360 to $1,900 \mathrm{mg} / \mathrm{L}$ in the upper Potomac aquifer. Research-station well clusters on the Eastern Shore also indicate a stronger regional freshwater influence in the northern part of the Eastern Shore than in the southern part. The vertical chloride distribution is shown in table 7 for the two research-station well clusters on the Eastern Shore that have wells located in the upper Potomac aquifer. At the Jenkins Bridge Research Station, chloride concentrations are lower in the upper Potomac aquifer $(1,500 \mathrm{mg} / \mathrm{L})$ than in the overlying St. Marys-Choptank $(3,800 \mathrm{mg} / \mathrm{L})$ and lower Yorktown-Eastover $(2,100 \mathrm{mg} / \mathrm{L})$ aquifers. The vertical profile of chloride concentrations from the 


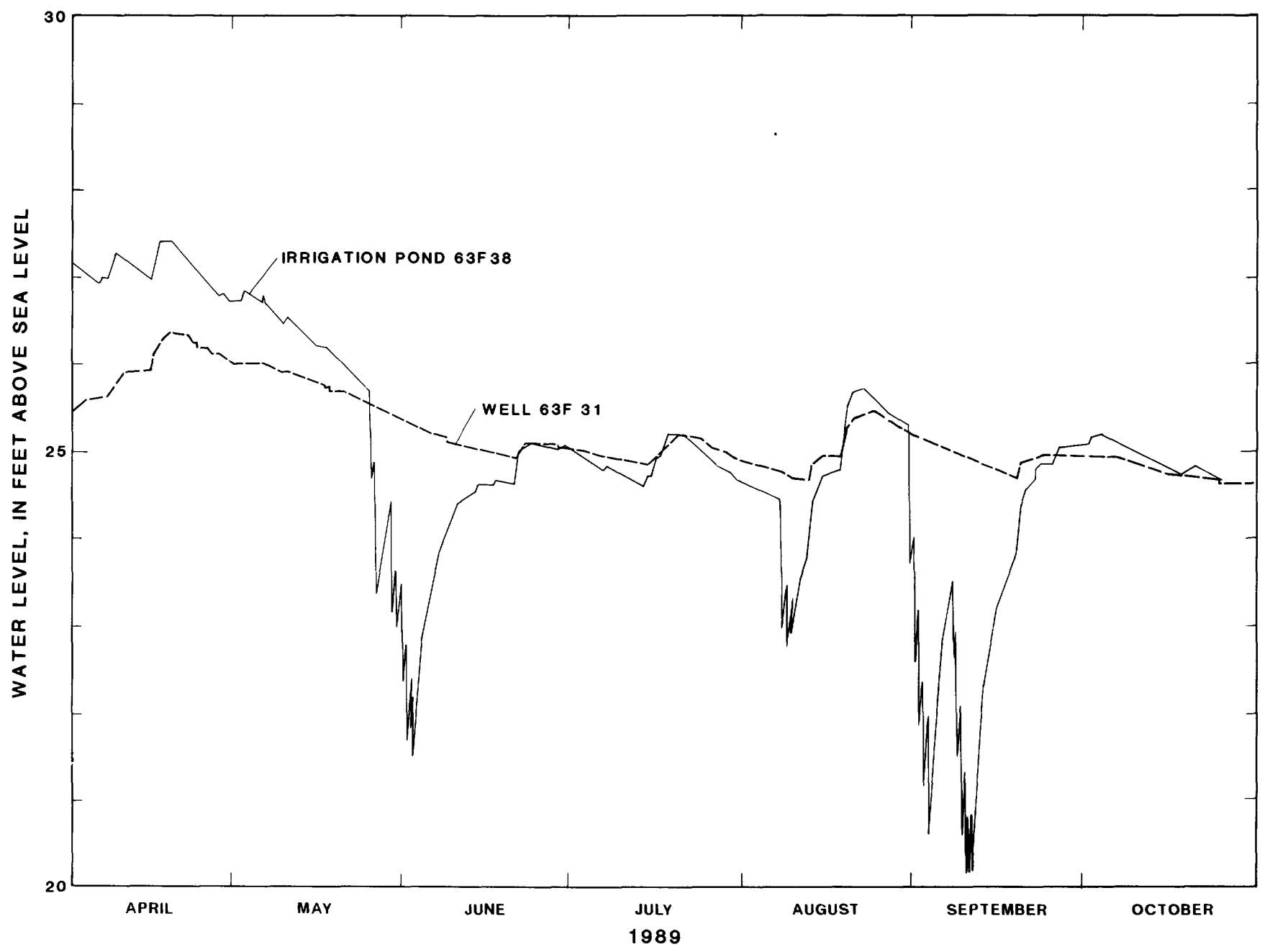

Figure 14. Water levels in an irrigation pond and in a nearby well completed in the Columbia aquifer.

Jenkins Bridge Research Station indicates that the origin of the freshwater in the upper Potomac aquifer is freshwater flowing beneath the Chesapeake Bay from the mainland of Virginia and Maryland (fig. 17, table 7). The vertical profile of chloride concentrations for the Kiptopeke Research Station at the southern tip of the Eastern Shore shows increasing chloride concentrations with depth at this location (table 7). Well 63F52 at the Kiptopeke Research Station is located farther west than well $66 \mathrm{M} 23$ at the Jenkins Bridge Research Station (fig. 17); however, the freshwater flow beneath the Chesapeake Bay does not extend as far to the east at the southern tip of the peninsula as it does at the northern part of the peninsula. The chloride concentration in ground water in the upper Potomac aquifer of
$24,000 \mathrm{mg} / \mathrm{L}$ indicates highly saline water at well 63F52 and no fresh ground-water flow.

\section{Ground-Water Use}

Prior to 1965 , there were few large users of ground water on the Eastern Shore. By 1970, increased population combined with commercial and industrial growth created a greatly increased demand for the ground-water resource. Major pumping centers on the Eastern Shore are located near the towns of Chincoteague, Hallwood, Accomac, Exmore, Oyster, Cheriton, and Cape Charles, Va.

Annual ground-water withdrawal data for the model area were compiled by confined aquifer for commercial, industrial, and municipal withdrawals 


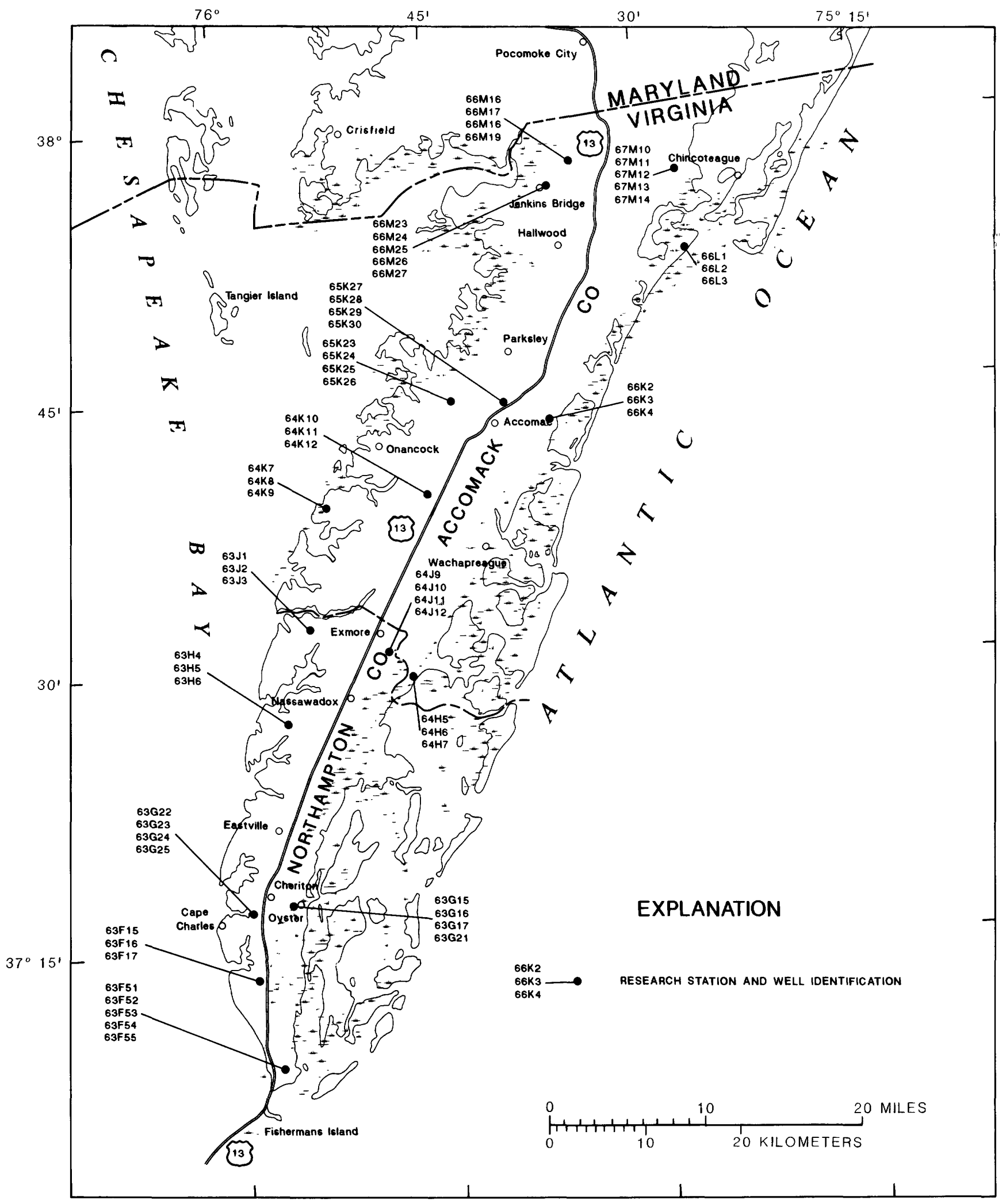

Figure 15. Location of selected Virginia Water Control Board research-station well clusters. 
Table 6. Selected Virginia Water Control Board research-station well clusters on the Eastern Shore [Latitude and longitude are reported in degrees, arc minutes, and arc seconds; USGS, U.S. Geological Survey; VWCB, Virginia Water Control Board]

\begin{tabular}{|c|c|c|c|c|c|}
\hline $\begin{array}{l}\text { USGS } \\
\text { well } \\
\text { number }\end{array}$ & $\begin{array}{l}\text { VWCB } \\
\text { well } \\
\text { number }\end{array}$ & Latitade & Longitude & $\begin{array}{l}\text { Well } \\
\text { depth } \\
\text { (feet) }\end{array}$ & Aquifer penetrated \\
\hline $66 \mathrm{~K} 4$ & SOW 101A & 374320 & 0753656 & 152 & Upper Yorktown-Eastover \\
\hline $66 \mathrm{~K} 3$ & SOW $101 \mathrm{~B}$ & 374320 & 0753805 & 220 & Middle Yorktown-Eastover \\
\hline $66 \mathrm{~K} 2$ & SOW 101C & 374319 & 0753654 & 292 & Lower Yorktown-Eastover \\
\hline 64H 6 & SOW 102A & 372925 & 0754704 & 154 & Upper Yorktown-Eastover \\
\hline $64 \mathrm{H} 7$ & SOW $102 B$ & 372921 & 0754705 & 220 & Middle Yorktown-Eastover \\
\hline $64 \mathrm{H} 5$ & SOW $102 \mathrm{C}$ & 372921 & 0754705 & 306 & Lower Yorktown-Eastover \\
\hline $63 \mathrm{H} 6$ & SOW 103A & 372705 & 0755559 & 37 & Columbia \\
\hline 63H 5 & SOW 103B & 372705 & 0755559 & 132 & Upper Yorktown-Eastover \\
\hline 63H 4 & Sow $103 \mathrm{C}$ & 372706 & 0755559 & 235 & Lower Yorktown-Eastover \\
\hline $63 G 21$ & SOW 104S & 371709 & 0755608 & 36 & Columbia \\
\hline 63G 17 & SOW 104A & 371709 & 0755608 & 140 & Upper Yorktown-Eastover \\
\hline 63G 16 & SOW 104B & 371709 & 0755608 & 240 & Middle Yorktown-Eastover \\
\hline $63 G 15$ & SOW $104 \mathrm{C}$ & 371709 & 0755607 & 310 & Lower Yorktown-Eastover \\
\hline $63 F 15$ & SOW 105A & 371307 & 0755835 & 130 & Upper Yorktown-Eastover \\
\hline 63F 17 & SOW 105B & 371307 & 0755835 & 196 & Middle Yorktown-Eastover \\
\hline 63F 16 & SOW $105 \mathrm{C}$ & 371307 & 0755835 & 285 & Lower Yorktown-Eastover \\
\hline $64 \mathrm{~K} 9$ & SOW 106A & 373845 & 0755225 & 37 & Columbia \\
\hline $64 \mathrm{~K} 8$ & SOW 106B & 373845 & 0755225 & 95 & Upper Yorktown-Eastover \\
\hline $64 \mathrm{~K} 7$ & SOW $106 \mathrm{C}$ & 373845 & 0755225 & 176 & Lower Yorktown-Eastover \\
\hline $66 L 2$ & SOW 107A & 375225 & 0753217 & 140 & Upper Yorktown-Eastover \\
\hline $66\llcorner 3$ & SOW 107B & 375225 & 0753217 & 206 & Middle Yorktown-Eastover \\
\hline $66 \mathrm{~L}_{1}$ & sow $107 \mathrm{C}$ & 375225 & 0753217 & 305 & Lower Yorktown-Eastover \\
\hline $64 \mathrm{~K} 10$ & SOW 108A & 373932 & 0754527 & 50 & Columbia \\
\hline $64 \mathrm{~K} 11$ & SOW 108B & 373932 & 0754527 & 180 & Upper Yorktown-Eastover \\
\hline $64 \mathrm{~K} 12$ & SOW $108 \mathrm{C}$ & 373932 & 0754527 & 284 & Lower Yorktown-Eastover \\
\hline $65 \mathrm{~K} 26$ & SOW $109 \mathrm{~S}$ & 374442 & 0754325 & 25 & Columbia \\
\hline $65 \mathrm{~K} 24$ & SOW 109A & 374442 & 0754325 & 130 & Upper Yorktown-Eastover \\
\hline $65 \mathrm{~K} 25$ & SOW 109B & 374442 & 0754325 & 228 & Lower Yorktown-Eastover \\
\hline $65 \mathrm{~K} 23$ & Sow $109 \mathrm{C}$ & 374428 & 0754328 & 290 & Lower Yorktown-Eastover \\
\hline $66 \mathrm{M} 19$ & Sow 110 S & 375723 & 0753444 & 36 & Columbia \\
\hline $60 \mathrm{M} 16$ & SOW 110A & 375723 & 0753444 & 130 & Upper Yorktown-Eastover \\
\hline $66 \mathrm{M} 17$ & SOW 110B & 375723 & 0753444 & 178 & Middle Yorktown-Eastover \\
\hline $66 \mathrm{M} 18$ & SOW $110 \mathrm{C}$ & 375723 & 0753445 & 240 & Lower Yorktown-Eastover \\
\hline $63 G 25$ & SOW $111 \mathrm{~S}$ & 371653 & 0755848 & 70 & Columbia \\
\hline $63 G 22$ & SOW 111A & 371653 & 0755848 & 150 & Upper Yorktown-Eastover \\
\hline $63 G 23$ & SOW 111B & 371653 & 0755848 & 280 & Lower Yorktown-Eastover \\
\hline $63 G 24$ & Sow 111C & 371653 & 0755848 & 330 & Lower Yorktown-Eastover \\
\hline $64 \mathrm{~J} 12$ & SOW $112 \mathrm{~S}$ & 373059 & 0754845 & 47 & Columbia \\
\hline $64 \mathrm{~J} 9$ & SOW $112 A$ & 373059 & 0754845 & 135 & Upper Yorktown-Eastover \\
\hline $64 \mathrm{~J} 10$ & SOW $112 B$ & 373059 & 0754845 & 210 & Middle Yorktown-Eastover \\
\hline 64J 11 & SOW $112 \mathrm{C}$ & 373059 & 0754845 & 313 & Lower Yorktown-Eastover \\
\hline 63J 1 & SOW 113A & 373216 & 0755407 & 120 & Upper Yorktown-Eastover \\
\hline 63J 2 & SOW 113B & 373216 & 0755407 & 225 & Middle Yorktown-Eastover \\
\hline $63 J 3$ & SOW $113 \mathrm{C}$ & 373216 & 0755407 & 290 & Lower Yorktown-Eastover \\
\hline $65 \mathrm{~K} 30$ & SOW 114S & 374425 & 0754000 & 40 & Columbia \\
\hline
\end{tabular}


Table 6. Selected Virginia Water Control Board research-station well clusters on the Eastern ShoreContinued

\begin{tabular}{|c|c|c|c|c|c|}
\hline $\begin{array}{l}\text { USGS } \\
\text { well } \\
\text { number }\end{array}$ & $\begin{array}{l}\text { VWCB } \\
\text { well } \\
\text { number }\end{array}$ & Latitude & Longitude & $\begin{array}{l}\text { Well } \\
\text { depth } \\
\text { (feet) }\end{array}$ & Aquifer penetrated \\
\hline $65 \mathrm{~K} 27$ & SOW 114A & 374425 & 0754000 & 160 & Upper Yorktown-Eastover \\
\hline $65 K 28$ & SOW 114B & 374425 & 0754000 & 230 & Middle Yorktown-Eastover \\
\hline $65 \mathrm{~K} 29$ & SOW $114 \mathrm{C}$ & 374427 & 0754000 & 315 & Lower Yorktown-Eastover \\
\hline $67 \mathrm{M} 10$ & SOW 115A & 375635 & 0752715 & 52 & Columbia \\
\hline 67M 11 & SOW 115B & 375635 & 0752715 & 138 & Upper Yorktown-Eastover \\
\hline $67 M 12$ & sow $115 \mathrm{C}$ & 375635 & 0752715 & 222 & Middle Yorktown-Eastover \\
\hline $67 \mathrm{M} 13$ & SOW 115D & 375635 & 0752715 & 249 & Middle Yorktown-Eastover \\
\hline $67 \mathrm{M} 14$ & SOW 115E & 375617 & 0752737 & 280 & Middle Yorktown-Eastover \\
\hline $60 \mathrm{M} 23$ & SOW 181A & 375610 & 0753618 & 1,300 & Upper Potomac \\
\hline $66 \mathrm{M} 24$ & SOW 181B & 375610 & 0753618 & 508 & St. Marys \\
\hline $66 \mathrm{M} 25$ & SOW 181C & 375610 & 0753618 & 340 & Lower Yorktown-Eastover \\
\hline $60 \mathrm{M} 26$ & SOW 181D & 375610 & 0753618 & 230 & Lower Yorktown-Eastover \\
\hline $60 \mathrm{M} 27$ & SOW 181E & 375610 & 0753618 & 30 & Columbia \\
\hline 63F 51 & SOW 182A & 370807 & 0755708 & 1,730 & Middle Potomac \\
\hline $63 F 52$ & SOW 182B & 370807 & 0755708 & 1,332 & Upper Potomac \\
\hline 63F 53 & SOW $182 C$ & 370807 & 0755708 & 220 & Lower Yorktown-Eastover \\
\hline 63F 54 & SOW $182 D$ & 370807 & 0755708 & 60 & Upper Yorktown-Eastover \\
\hline 63F 55 & SOW 182E & 370807 & 0755708 & 20 & Columbia \\
\hline
\end{tabular}

Table 7. Vertical distribution of chloride concentrations in ground water at Jenkins Bridge and Kiptopeke Research Station well clusters

[USGS, U.S. Geological Survey; mg/L, milligrams per liter]

\begin{tabular}{|c|c|c|c|c|}
\hline $\begin{array}{l}\text { USGS } \\
\text { well } \\
\text { number }\end{array}$ & $\begin{array}{l}\text { Well } \\
\text { depth } \\
\text { (feet) }\end{array}$ & Aquifer & Date & $\begin{array}{c}\text { Chloride } \\
\text { concentration } \\
(\mathrm{mg} / \mathrm{L})\end{array}$ \\
\hline \multicolumn{5}{|c|}{ Jenkins Bridge Research Station } \\
\hline \multirow[t]{2}{*}{$66 \mathrm{M} 27$} & 40 & Columbia & $10-29-87$ & 31 \\
\hline & & & $08-29-88$ & 23 \\
\hline \multirow[t]{2}{*}{$66 \mathrm{M} 26$} & 230 & Lower Yorktown-Eastover & $10-30-87$ & 1,000 \\
\hline & & & $08-29-88$ & 810 \\
\hline \multirow[t]{2}{*}{$66 \mathrm{M} 25$} & 340 & Lower Yorktown-Eastover & $10-30-87$ & 2,100 \\
\hline & & & $08-29-88$ & 2,100 \\
\hline \multirow[t]{2}{*}{$66 \mathrm{M} 24$} & 508 & St. Marys - Choptank & $10-28-87$ & 3,900 \\
\hline & & & $08-29-88$ & 3,800 \\
\hline \multirow[t]{2}{*}{$60 \mathrm{M} 25$} & 1,320 & Upper Potomac & $10-29-87$ & 1,500 \\
\hline & & & $08-29-88$ & 1,500 \\
\hline
\end{tabular}

Kiptopeke Research Station

\begin{tabular}{lrlrr}
$63 F 55$ & 20 & Columbia & $11-16-89$ & 24 \\
$63 F 54$ & 60 & Upper Yorktown-Eastover & $11-16-89$ & 32 \\
$63 F 53$ & 220 & Lower Yorktown-Eastover & $11-16-89$ & 59 \\
$63 F 52$ & 1,332 & Upper Potomac & $11-29-89$ & 24,000 \\
\hline
\end{tabular}



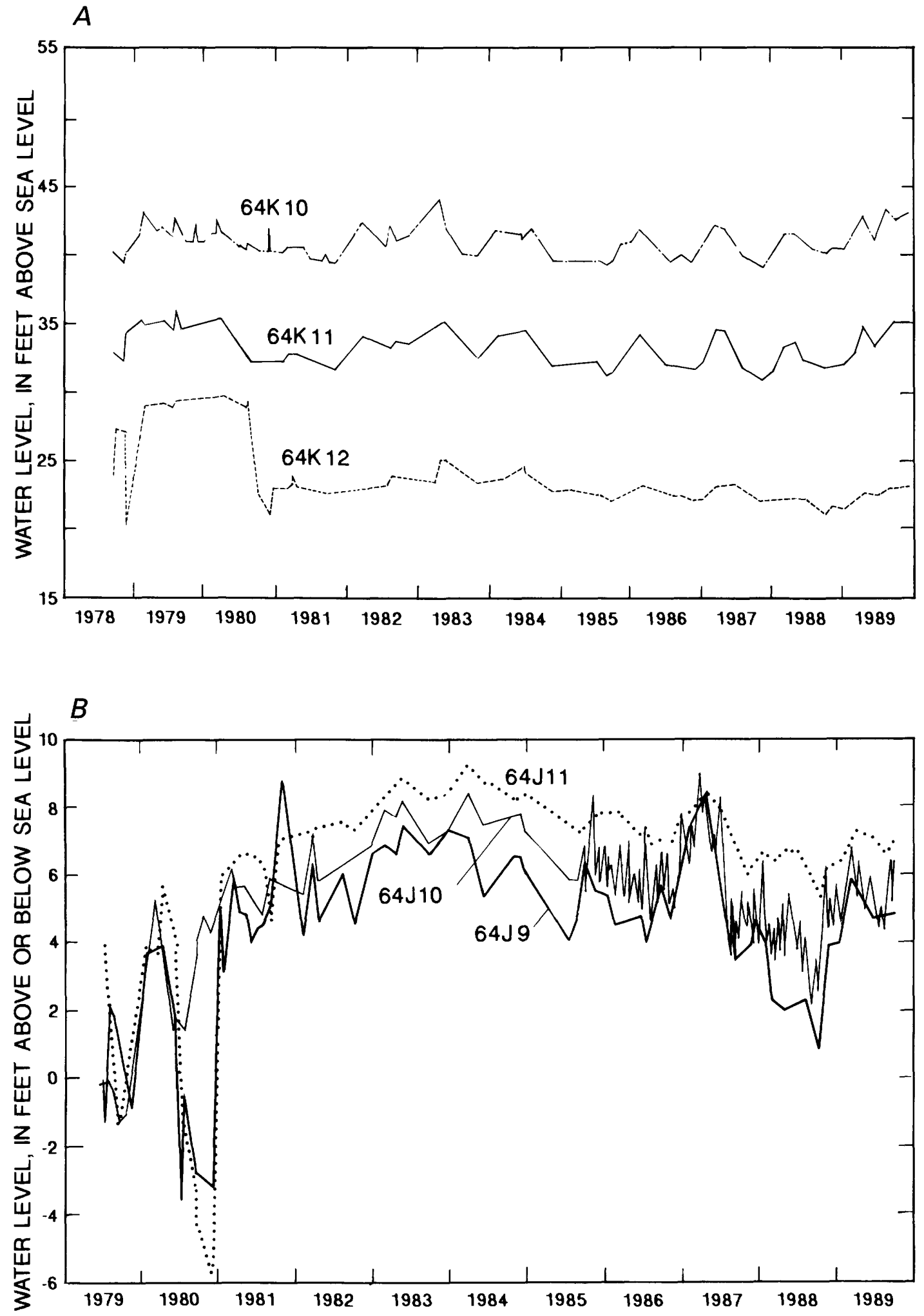

Figure 16. Water levels in research-station well clusters $(A)$ in a recharge area and $(B)$ in a discharge area. 


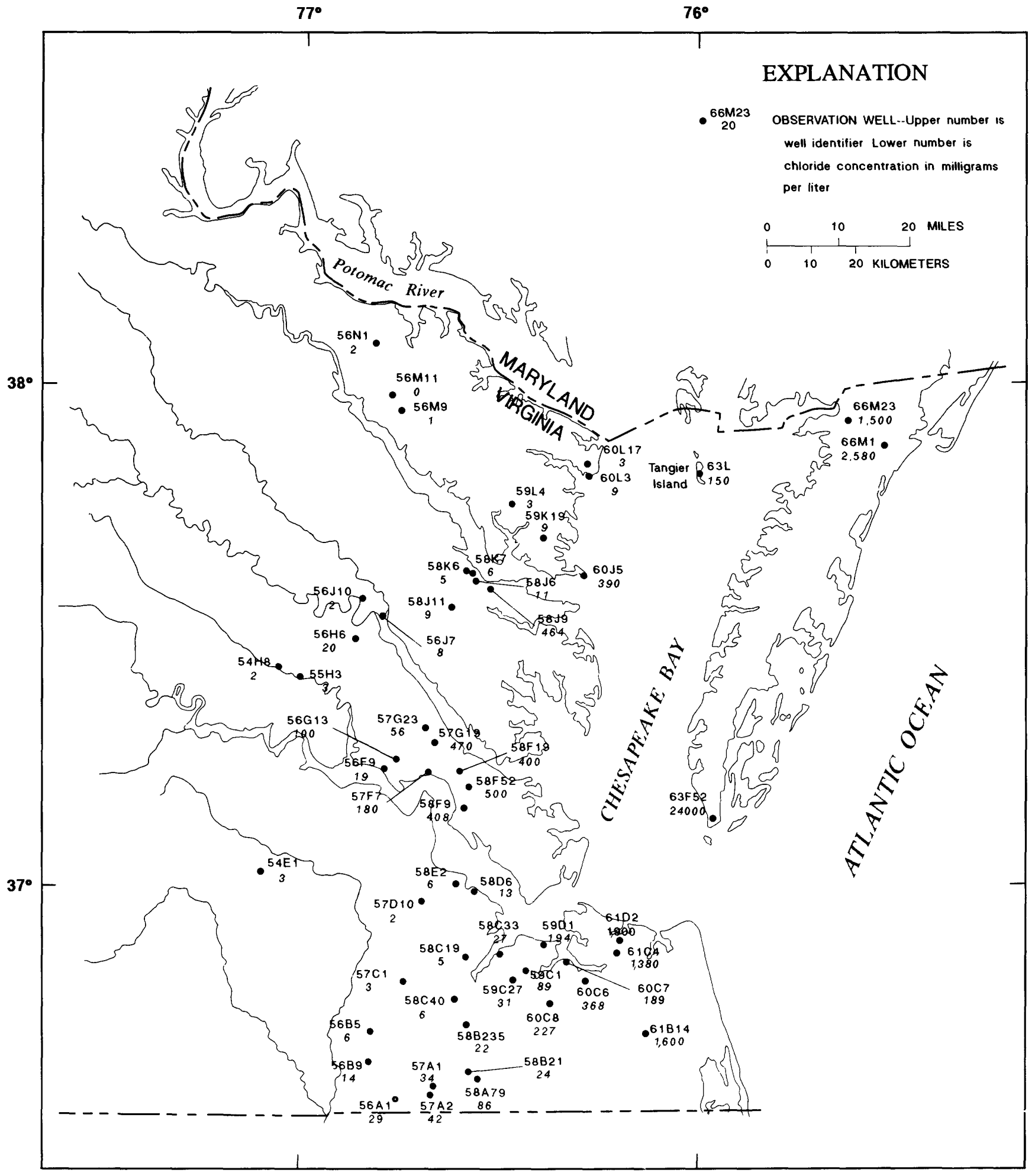

Figure 17. Location of observation wells and chloride concentrations in the upper Potomac aquifer for the Coastal Plain of Virginia. 


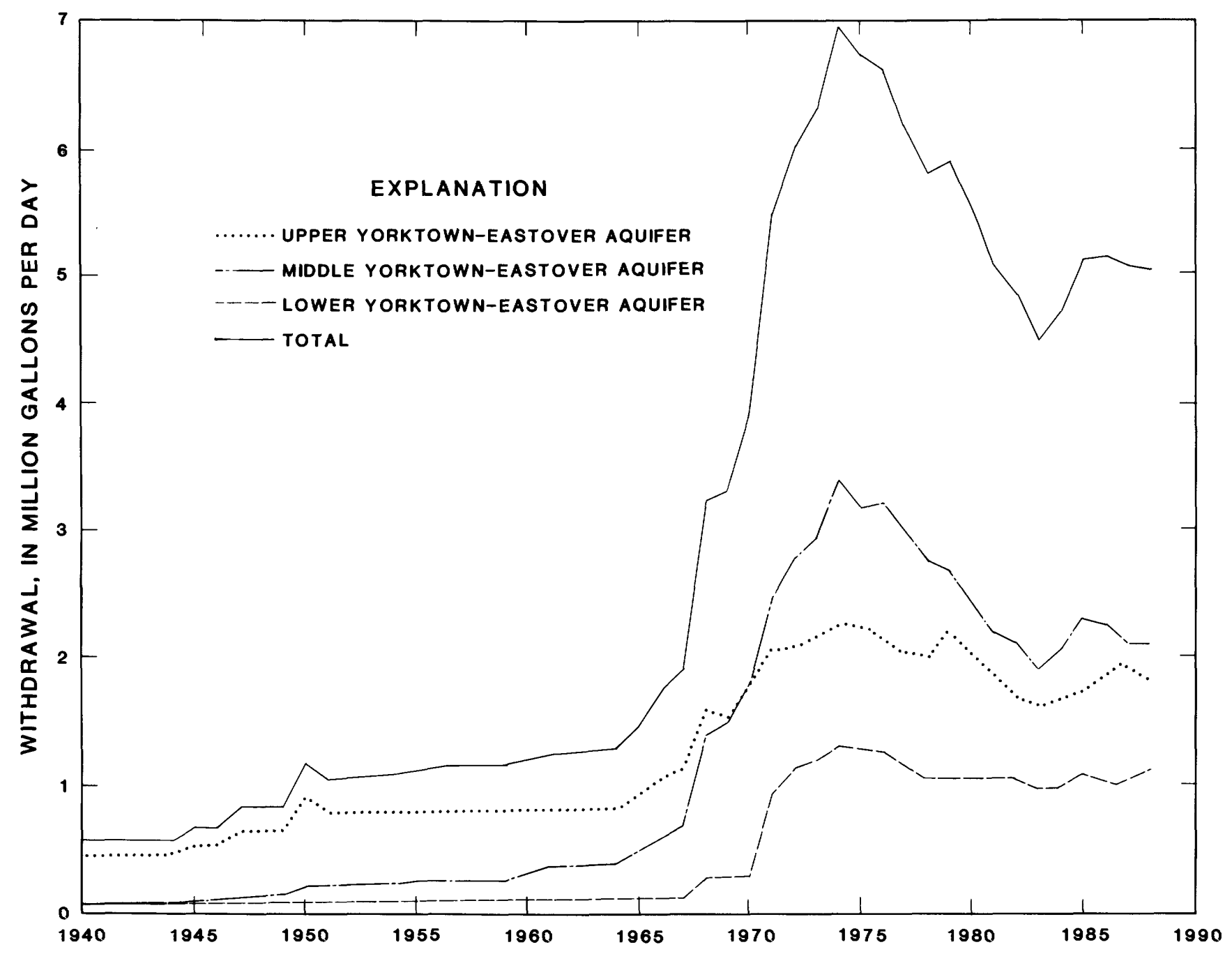

Figure 18. Annual ground-water withdrawal from model area.

(fig. 18). Estimates do not include domestic or agricultural withdrawals. Domestic use is not included because currently there is no practical method of collecting such data by aquifer, and it is assumed to represent only a small percentage of nonreturned water. Agricultural use is significant on the Eastern Shore; however, agricultural users are not required to report withdrawals. As a result, the specific locations and aquifers tapped for agricultural withdrawals are unknown. Most of the ground water used for agricultural purposes is withdrawn from irrigation ponds in the unconfined Columbia aquifer. All other ground-water users in Northampton and Accomack Counties that withdraw over $300,000 \mathrm{gal} / \mathrm{month}$ are required to report usage data to the VWCB. The depth of the well screen was used to determine the aquifer from which water was pumped. For wells screened in multiple aquifers, water-withdrawal rates from each aquifer were estimated from the ratio of the length of screen in each aquifer to the total length of well screen.

The middle and upper Yorktown-Eastover aquifers have historically provided most of the freshwater to users on the Eastern Shore. Prior to 1968, the largest withdrawals were from the shallowest confined aquifer, the upper YorktownEastover. By 1970, the middle Yorktown-Eastover aquifer was contributing more water than the upper or lower Yorktown-Eastover aquifers, and pumpage from the lower Yorktown-Eastover aquifer was increasing. Estimated ground-water use peaked in 1974 at $6.96 \mathrm{Mgal} / \mathrm{d}$. The decline in water use for 
the period 1975-83 represents the loss of several major industrial users. Since 1985 , water use has generally been steady. Total ground-water use was estimated to be about $5.04 \mathrm{Mgal} / \mathrm{d}$ in 1988. The upper Yorktown-Eastover aquifer supplied 36 percent of the withdrawal in 1988, and the middle and lower Yorktown-Eastover aquifers supplied 42 and 22 percent, respectively.

\section{Chloride Distribution}

Chloride concentrations were compiled by aquifer to provide information on the distribution of chlorides in the aquifers that currently are being used as a freshwater supply for the Eastern Shore (figs. 19-22). The chloride concentrations presented on the maps are the most recent chloride analyses for each well. Individual chloride analyses are presented by aquifer in tables 8-11. Chloride concentrations typically are greater along the coast than in the center of the peninsula. Chloride concentrations in water collected from wells in the Columbia aquifer and the upper Yorktown-Eastover aquifer were less than the U.S. Environmental Protection Agency (USEPA) secondary drinking-water regulation of $250 \mathrm{mg} / \mathrm{L}$ (U.S. Environmental Protection Agency, 1989). The line delineating the approximate limit of the $250 \mathrm{mg} / \mathrm{L}$ chloride concentration in the Columbia aquifer was estimated to be the landward limit of the saltwater marshes and estuaries (fig. 19). All chlorides from the upper Yorktown-Eastover aquifer were well below the $250 \mathrm{mg} / \mathrm{L}$ limit; therefore, the limit line was estimated based on the understanding of the ground-water-flow system (fig. 20). Chloride concentrations probably are less than $250 \mathrm{mg} / \mathrm{L}$ in the upper Yorktown-Eastover aquifer beneath all major land surfaces on the peninsula. Chloride concentrations generally increase with depth; greater chloride concentrations are found in the lower Yorktown-Eastover aquifer than in the overlying middle Yorktown-Eastover, upper YorktownEastover, and Columbia aquifers. Chloride concentrations in water in the lower Yorktown-Eastover aquifer are stratified; concentrations are less near the top of the aquifer than near the bottom of the aquifer. Data indicate an area of elevated chloride concentrations in water in the middle and lower Yorktown-Eastover aquifer near Exmore, Va. (figs. 21, 22). The elevated concentrations appear to be in the area of an ancient Pleistocene river chan- nel (described in Pleistocene Paleochannel Aquifers section). The erosion of the original aquifer and confining-unit materials combined with the different hydraulic characteristics of the backfilled-channel sediments could result in a better hydraulic connection between the freshwater-flow system and the saltwater-flow system in this area. A detailed study of the extent of the erosion and the hydraulic properties of the channel-fill sediments is needed for a complete understanding of saltwater-freshwater relations in this part of the ground-water-flow system. Elevated chloride concentrations in water in the middle and lower Yorktown-Eastover aquifers also are present near Cape Charles, Va. This area could be affected by the southernmost paleochannel or by incision from a nearshore channel in the present-day Chesapeake Bay.

\section{ANALYSIS OF THE GROUND-WATER- FLOW SYSTEM}

The conceptualization of the physical characteristics of the three-dimensional, multiaquifer, flow system can be incorporated into a digital groundwater-flow model. The model is a mathematical representation of the natural system and includes many simplifying assumptions. Model input parameters are based on the measured and estimated characteristics of the aquifers and confining units. The model is calibrated by comparing simulated water levels to water levels measured at observation wells. Once calibrated, the digital model can be used within its limitations to simulate changes in ground-water-flow conditions that result from changes in hydrologic stresses. A digital model can assist in analyzing a ground-water system; however, it is important to realize that the model is only an approximate representation of the actual physical system.

\section{Development of the Flow Model}

A ground-water-flow model was developed for the Eastern Shore using SHARP (Essaid, 1990a), a numerical finite-difference model that uses a quasithree-dimensional approach to simulate freshwater and saltwater flow separated by a sharp interface. The sharp-interface approach assumes that saltwaterbetween saltwater and freshwater is small relative to the thickness of the aquifer. The approach does not provide information on the physical or chemical 


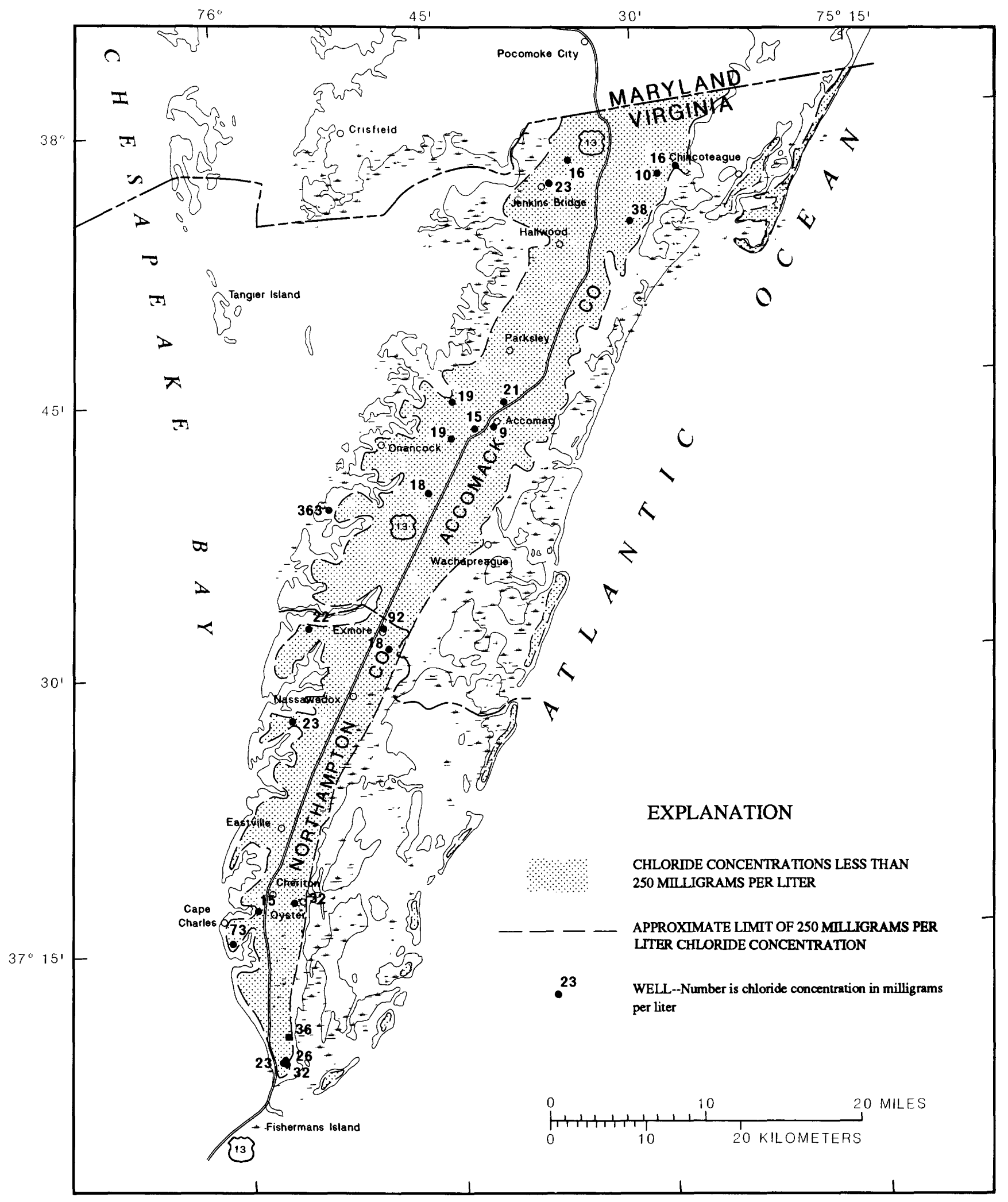

Figure 19. Chloride concentrations in the Columbia aquifer. 


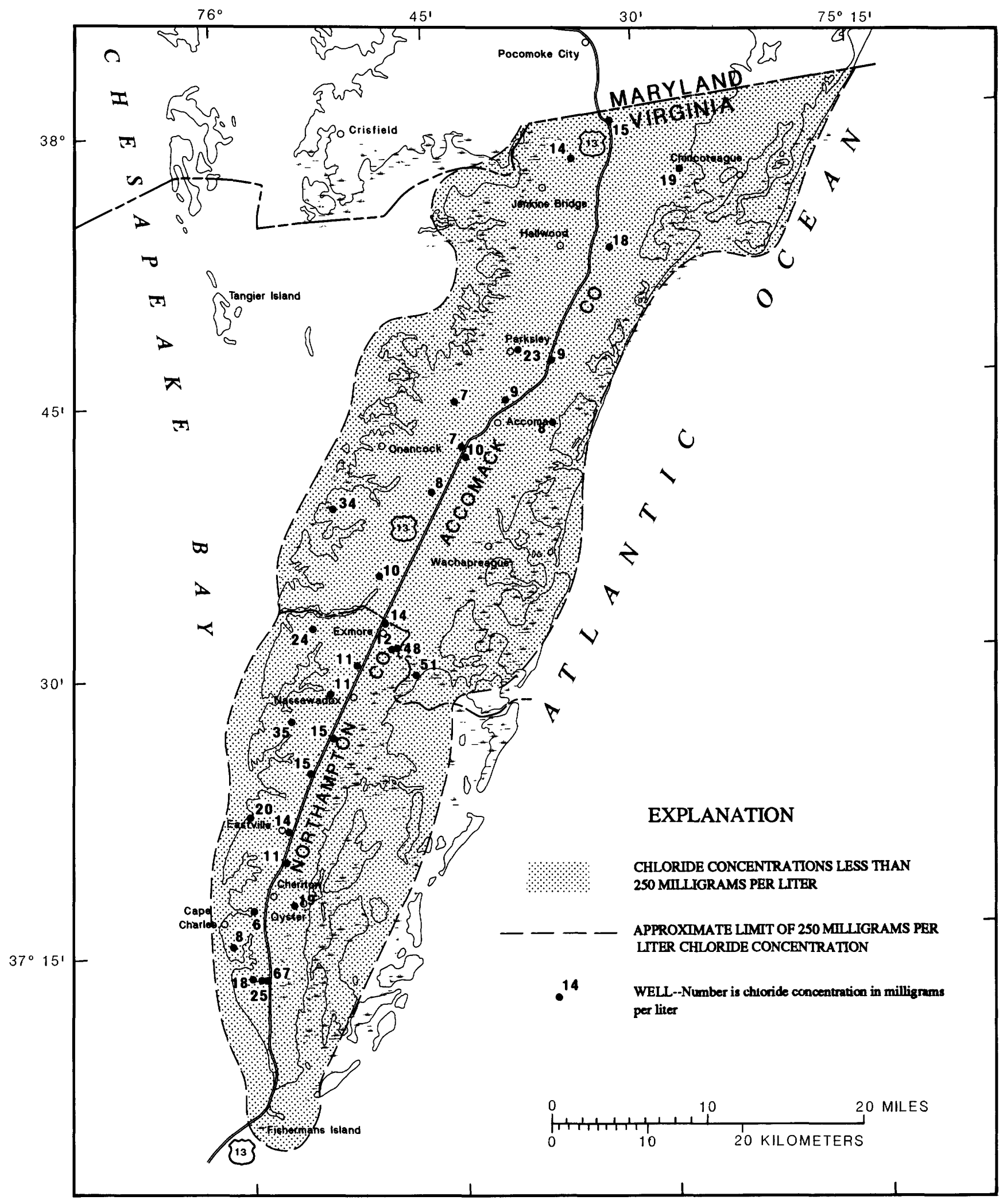

Figure 20. Chloride concentrations in the upper Yorktown-Eastover aquifer. 


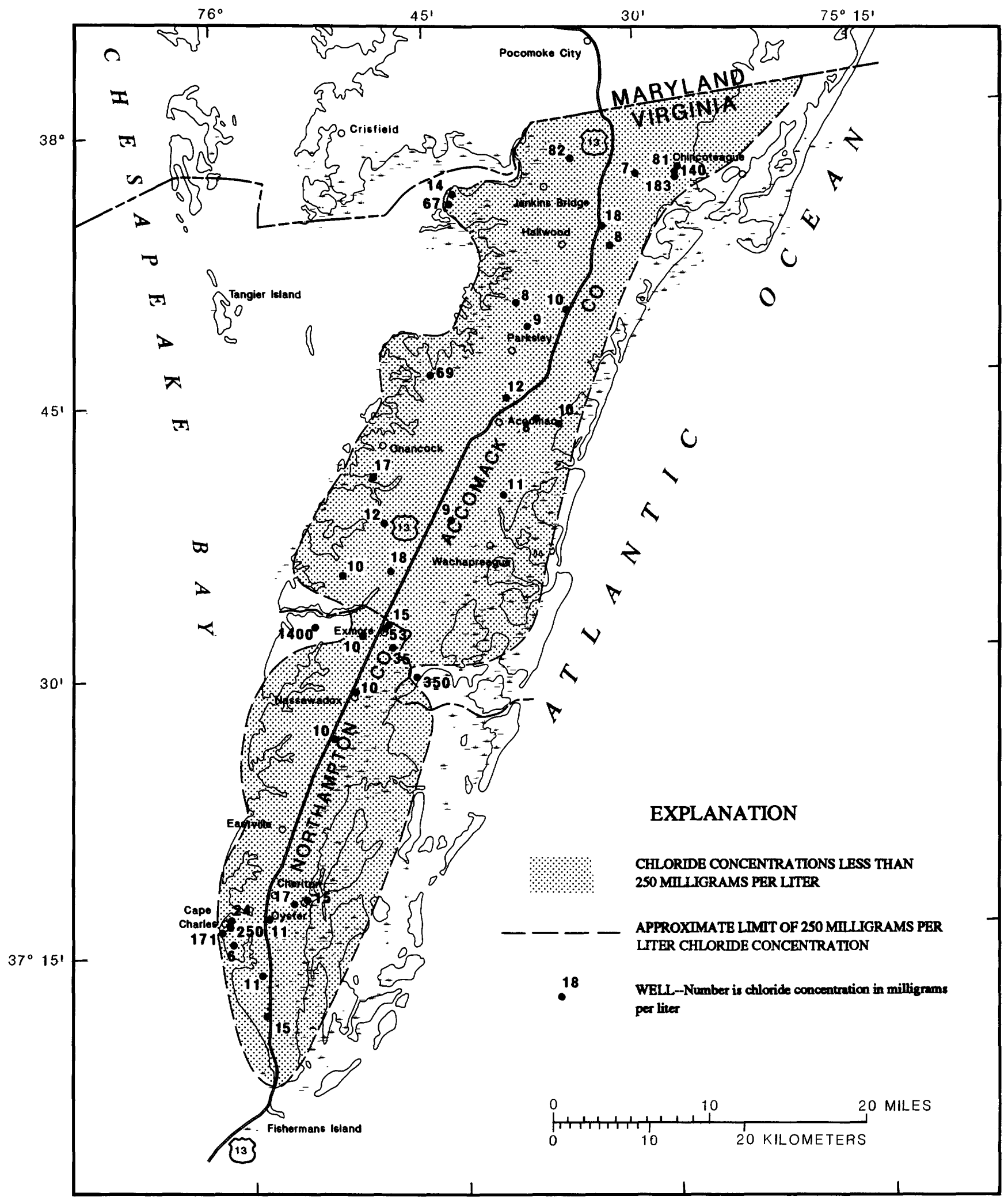

Figure 21. Chloride concentrations in the middle Yorktown-Eastover aquifer. 


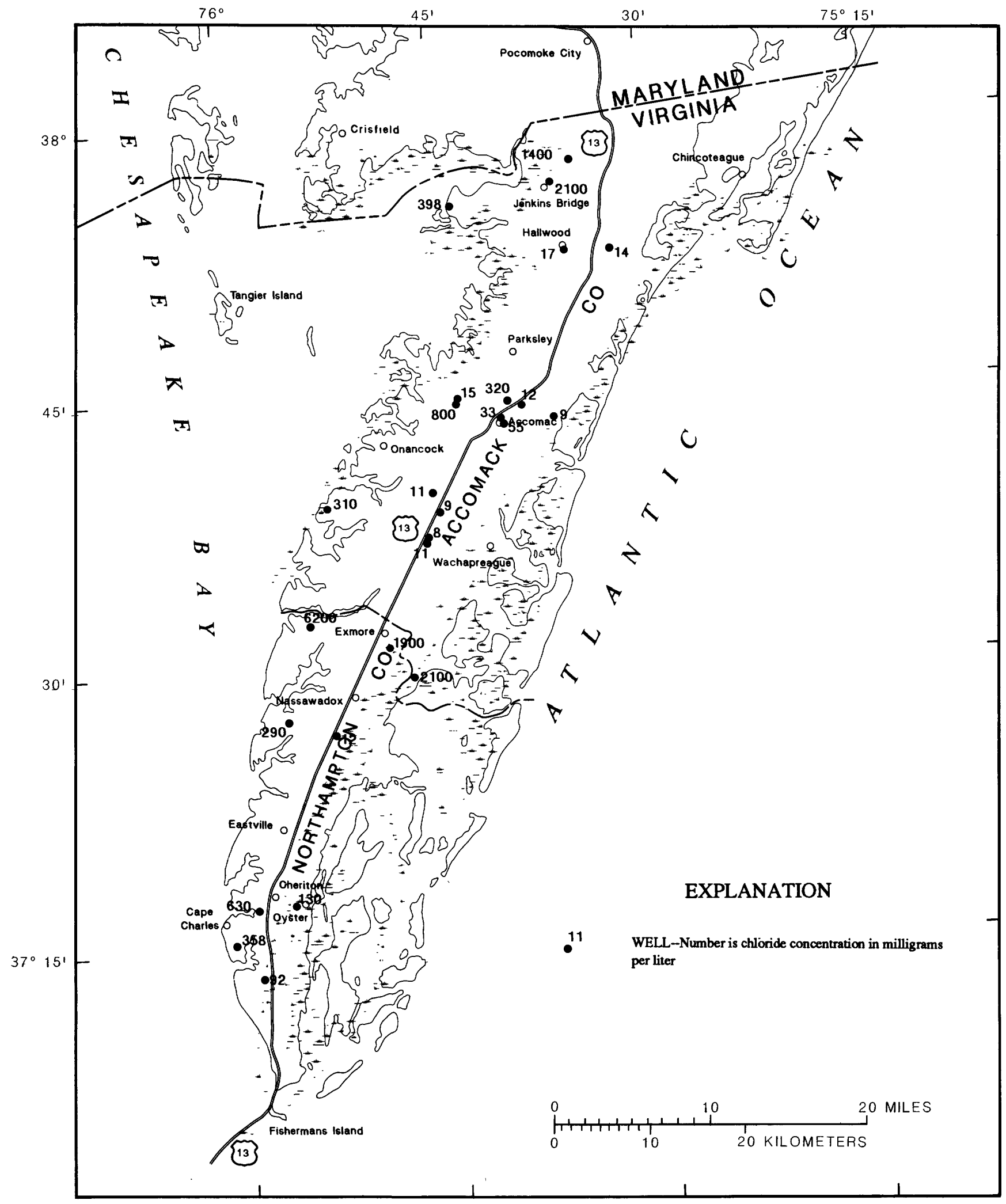

Figure 22. Chloride concentrations in the lower Yorktown-Eastover aquifer. 
Table 8. Chloride concentrations in the Columbia aquifer

[USGS, U.S. Geological Survey; VWCB, Virginia Water Control Board; latitude and longitude are reported in degrees, arc minutes, arc seconds; $\mathrm{mg} / \mathrm{L}$, milligrams per liter]

\begin{tabular}{|c|c|c|c|c|c|c|c|}
\hline $\begin{array}{l}\text { USGS } \\
\text { well } \\
\text { number }\end{array}$ & Latitude & Longitude & $\begin{array}{l}\text { Well } \\
\text { depth } \\
\text { (feet) }\end{array}$ & $\begin{array}{l}\text { Land- } \\
\text { surface } \\
\text { altitude } \\
\text { (feet) }\end{array}$ & $\begin{array}{l}\text { Chloride } \\
\text { concentration } \\
(\mathrm{mg} / \mathrm{L})\end{array}$ & $\begin{array}{l}\text { Date } \\
\text { sampled }\end{array}$ & $\begin{array}{l}\text { Sampling } \\
\text { agency }\end{array}$ \\
\hline
\end{tabular}

\begin{tabular}{|c|c|c|c|c|c|c|c|}
\hline 62F 4 & 371456 & 0760030 & 40 & 10 & 73 & $12-01-77$ & VẉCB \\
\hline $63 F 6$ & 370806 & 0755718 & 74 & 10 & 54 & $09-27-55$ & USGS \\
\hline 63F 19 & 370806 & 0755709 & 60 & 10 & 23 & $01-02-75$ & VWCB \\
\hline $63 F 20$ & 370806 & 0755708 & 62 & 10 & 26 & $01-02-75$ & VWCB \\
\hline \multirow[t]{3}{*}{ 63F 21} & 370806 & 0755707 & 65 & 10 & 31 & $01-02-75$ & VWCB \\
\hline & & & & & 32 & $02-12-75$ & VWCB \\
\hline & & & & & 32 & $12-12-75$ & VẈCB \\
\hline \multirow[t]{2}{*}{$63 F 22$} & 370939 & 0755704 & 46 & 10 & 27 & 01-02-75 & VWCB \\
\hline & & & & & 36 & $12-12-75$ & VWCB \\
\hline \multirow[t]{3}{*}{ 63G 21} & 371709 & 0755608 & 36 & 30 & 66 & $10-03-77$ & VWCB \\
\hline & & & & & 43 & $08-19-80$ & VWCB \\
\hline & & & & & 32 & $08-04-86$ & VWCB \\
\hline \multirow[t]{2}{*}{$63 G 25$} & 371653 & 0755848 & 70 & 15 & 13 & $06-29-79$ & VWCB \\
\hline & & & & & 15 & $08-19-80$ & VWCB \\
\hline \multirow[t]{3}{*}{$63 \mathrm{H} .6$} & 372705 & 0755559 & 37 & 17 & 43 & $09-28-77$ & VWCB \\
\hline & & & & & 30 & $05-11-79$ & VWCB \\
\hline & & & & & 23 & $06-26-84$ & VWCB \\
\hline $63 \mathrm{~J} 4$ & 373220 & 0755415 & 40 & 25 & 22 & $05-11-84$ & VWCB \\
\hline \multirow[t]{2}{*}{ 64J 12} & 3730.59 & 0754845 & 47 & 30 & 23 & $07-03-79$ & VWCB \\
\hline & & & & & 18 & $08-21-80$ & VWCB \\
\hline \multirow[t]{3}{*}{$64 \mathrm{~J} 26$} & 373200 & 0754917 & 58 & 35 & 41 & $03-01-67$ & VWCB \\
\hline & & & & & 105 & 04-01-75 & VWCB \\
\hline & & & & & 92 & $09-19-78$ & VWCB \\
\hline \multirow[t]{3}{*}{$64 \mathrm{~K} 9$} & 373845 & 0755225 & 37 & 2 & 78 & $09-21-77$ & VWCB \\
\hline & & & & & 92 & $08-20-80$ & VWCB \\
\hline & & & & & 363 & $06-26-84$ & VWCB \\
\hline \multirow[t]{2}{*}{$64 \mathrm{~K} 10$} & 373932 & 0754527 & 50 & 45 & 6 & $08-20-80$ & VWCB \\
\hline & & & & & 18 & $06-29-84$ & VWCB \\
\hline $65 \mathrm{~K} 21$ & 374257 & 0754041 & 45 & 42 & 9 & $09-28-71$ & VWCB \\
\hline $65 \mathrm{~K} 26$ & 374442 & 0754325 & 25 & 10 & 19 & $08-20-80$ & VWCB \\
\hline \multirow[t]{2}{*}{$65 \mathrm{~K} 30$} & 374425 & 0754000 & 40 & 45 & 12 & $02-13-80$ & VWCB \\
\hline & & & & & 21 & $08-26-80$ & VWCB \\
\hline $65 \mathrm{~K} 32$ & 374232 & 0754342 & 52 & 30 & 19 & $08-07-81$ & VWCB \\
\hline $65 \mathrm{~K} 33$ & 374249 & 0754207 & 55 & 40 & 15 & $08-07-81$ & VWCB \\
\hline \multirow[t]{2}{*}{$66 \mathrm{M} 19$} & 375723 & 0753444 & 36 & 10 & 15 & $08-26-80$ & VWCB \\
\hline & & & & & 16 & $07-11-84$ & VWCB \\
\hline $66 \mathrm{M} 21$ & 375403 & 0753025 & 69 & 35 & 38 & $08-04-81$ & VWCB \\
\hline \multirow[t]{2}{*}{$60 \mathrm{M} 27$} & 375610 & 0753618 & 30 & 5 & 31 & $10-29-87$ & USGS \\
\hline & & & & & 23 & $08-29-88$ & USGS \\
\hline $67 M 6$ & 375624 & 0752836 & 45 & 30 & 10 & $08-17-48$ & VWCB \\
\hline \multirow[t]{3}{*}{$67 M 10$} & 375635 & 0752715 & 52 & 15 & 14 & $08-13-81$ & VWCB \\
\hline & & & & & 12 & $05-27-82$ & VWCB \\
\hline & & & & & 16 & $08-13-84$ & VWCB \\
\hline
\end{tabular}

nature of the transition zone; however, it does represent the overall ground-water flow in the system and will reproduce the general response of the interface to applied stresses (Essaid, 1986). The model represents regional-scale ground-water-flow systems as a layered sequence of two-dimensional aquifers sepa- rated by confining units that are represented by a vertical leakance term. Vertical gradients within aquifers are not represented; therefore, the modeling approach is not fully three-dimensional. The quasithree-dimensional solution of the ground-water-flow equation requires several assumptions: (1) flow in 
the aquifers is in the lateral direction, (2) vertical flow is controlled by confining units, and (3) water released from confining-unit storage is negligible. These assumptions are considered valid when the lateral and vertical hydraulic conductivities of the aquifers are much greater than those of the confining units, and simulation times are long enough to minimize the effects of water released from confining-unit storage.

The Eastern Shore is a peninsula surrounded by saltwater; therefore, the model's inclusion of saltwater-flow dynamics is of particular importance to an analysis of the ground-water system. Any change in offshore freshwater discharge induces movement of the interface between freshwater and saltwater. The rate of interface movement is a function of the flow conditions and aquifer properties of the freshwater and saltwater flow domains.

The model uses two vertically integrated, parabolic, partial-differential flow equations, representing freshwater and saltwater flow, which must be simultaneously solved for freshwater and saltwater head, as follows (Essaid, 1986):

$$
\begin{array}{r}
S_{f} B_{f} \frac{\partial \phi_{f}}{\partial t}+n \alpha \frac{\partial \phi_{f}}{\partial t}+\left[n \delta \frac{\partial \phi_{f}}{\partial t}-n(1+\delta) \frac{\partial \phi_{s}}{\partial t}\right] \\
=\frac{\partial}{\partial x}\left(B_{f} K_{f x} \frac{\partial \phi_{f}}{\partial x}\right)+\frac{\partial}{\partial y}\left(B_{f} K_{f y} \frac{\partial \phi_{f}}{\partial y}\right)+Q_{f} Q_{l f},
\end{array}
$$

and

$$
\begin{aligned}
S_{s} B_{s} \frac{\partial \phi_{s}}{\partial t} & +\left[n(1+\delta) \frac{\partial \phi_{s}}{\partial t}-n \delta \frac{\partial \phi_{f}}{\partial t}\right] \\
& =\frac{\partial}{\partial x}\left(B_{s} K_{s x} \frac{\partial \phi_{s}}{\partial_{x}}\right)+\frac{\partial}{\partial y}\left(B_{s} K_{s y} \frac{\partial \phi_{s}}{\partial y}\right)+Q_{s}+Q_{l s},
\end{aligned}
$$

where

$K_{f x}, K_{s x}=$ the freshwater and saltwater hydraulic conductivities in the $x$ direction $\left(L T^{-1}\right)$;

$K_{f y}, K_{s y}=$ the freshwater and saltwater hydraulic conductivities in the $y$ direction $\left(L T^{-1}\right)$;

$Q_{f}, Q_{s}=$ the freshwater and saltwater source/sink terms $\left(L T^{-1}\right)$;

$Q_{l f}, Q_{l s}=$ the freshwater and saltwater leakage terms $\left(L T^{-1}\right)$, calculated using Darcy's law;

$B_{f}, B_{s}=$ the thicknesses of the freshwater and saltwater zones $(L)$;

$S_{f}, S_{s}=$ the freshwater and saltwater specific stor-

$$
\begin{aligned}
& \text { ages }\left(L^{-1}\right) ; \\
\phi_{f}, \phi_{s}= & \text { freshwater and saltwater heads }(L) ; \\
n= & \text { effective porosity; } \\
t & =\text { time }(T) ; \text { and } \\
\alpha= & \text { a parameter equal to } 1 \text { for unconfined } \\
& \text { aquifers and zero for confined aquifers. }
\end{aligned}
$$

The flow equations for the freshwater and saltwater zones are coupled by the interface boundary condition. Continuity of flux and pressure must be maintained at the interface; the fluid pressure of the freshwater must equal the fluid pressure of the saltwater (Bear, 1979).

$$
p_{f}=\left(\phi_{f}-\zeta_{l}\right) \gamma_{f}=p_{s}=\left(\phi_{s}-\zeta_{l}\right) \gamma_{s},
$$

where

$p_{f}, p_{s}=$ the freshwater and saltwater fluid pressures $\left(M L^{-1} T^{-2}\right)$;

$\gamma_{f}, \gamma_{s}=$ the freshwater and saltwater specific weights $\left(M L^{-2} T^{-2}\right)$; and

$\zeta_{l}=$ the interface elevation $(L)$.

Solving for the interface elevation,

$$
\zeta_{l}=(1+\delta) \phi_{s}-\delta \phi_{f}
$$

where $\delta=\gamma_{f} /\left(\gamma_{s}-\gamma_{f}\right)$.

Once the freshwater and saltwater heads have been obtained from equations 1 and 2, the interface elevation can be calculated from equation 4 .

The SHARP model calculates and tracks the positions of the interface tip and toe in the finitedifference grid for each aquifer. The interface tip is the intersection of the interface with the top of the aquifer, and the interface toe is the intersection of the interface with the bottom of the aquifer (fig. 23). The interface position will not always coincide with the grid block boundaries. The tip and toe are located by linearly projecting the interface, based on the interface elevations at grid points. On the freshwater side of the interface toe, the entire thickness of the aquifer contains freshwater. Similarly, on the saltwater side of the interface tip, the entire thickness of the aquifer contains saltwater. In the area between the interface tip and toe, the aquifer contains freshwater and saltwater.

The sharp-interface approach assumes that saltwater and freshwater do not mix. Vertical leakage between saltwater and freshwater is restricted. Saltwater is not allowed to leak into the freshwater zone, and freshwater is not allowed to leak downward into the saltwater zone. A node can contain 
Table 9. Chloride concentrations in the upper Yorktown-Eastover aquifer

[USGS, U.S. Geological Survey; VWCB, Virginia Water Control Board; latitude and longitude are reported in degrees, arc minutes, arc seconds; $\mathrm{mg} / \mathrm{L}$, milligrams per liter]

\begin{tabular}{|c|c|c|c|c|c|c|c|}
\hline $\begin{array}{l}\text { USGS } \\
\text { well } \\
\text { number }\end{array}$ & Latitude & Longitude & $\begin{array}{l}\text { Well } \\
\text { depth } \\
\text { (feet) }\end{array}$ & $\begin{array}{l}\text { Land- } \\
\text { surface } \\
\text { altitude } \\
\text { (feet) }\end{array}$ & $\begin{array}{l}\text { Chloride } \\
\text { concentration } \\
(m g / L)\end{array}$ & $\begin{array}{l}\text { Date } \\
\text { sampled }\end{array}$ & $\begin{array}{l}\text { Sampling } \\
\text { agency }\end{array}$ \\
\hline $62 \mathrm{~F} 3$ & 371456 & 0760027 & 130 & 12 & 8 & $02-01-77$ & VWCB \\
\hline \multirow[t]{3}{*}{$63 \mathrm{~F} 15$} & 371307 & 0755835 & 130 & 31 & 20 & $06-07-78$ & VWCB \\
\hline & & & & & 25 & $08-11-80$ & VWCB \\
\hline & & & & & 25 & $07-12-84$ & VWCB \\
\hline 63F 18 & 371312 & 0755915 & 112 & 15 & 18 & $04-05-80$ & VWCB \\
\hline $63 \mathrm{~F} 24$ & 371302 & 0755807 & 140 & 37 & 67 & $01-08-81$ & USGS \\
\hline $63 \mathrm{G} 9$ & 372134 & 0755908 & 134 & 2 & 20 & $05-26-54$ & VWCB \\
\hline \multirow[t]{4}{*}{$63 \mathrm{G} 17$} & 371709 & 0755608 & 140 & 28 & 16 & $10-03-77$ & VWCB \\
\hline & & & & & 24 & 08-18-80 & VWCB \\
\hline & & & & & 24 & 08-06-84 & VWCB \\
\hline & & & & & 19 & 02-28-89 & USGS \\
\hline \multirow[t]{3}{*}{ 63G 22} & 371653 & 0755848 & 150 & 15 & 8 & 06-29-79 & VWCB \\
\hline & & & & & 8 & 08-19-80 & VWCB \\
\hline & & & & & 6 & $07-12-84$ & VWCB \\
\hline \multirow[t]{13}{*}{ 63G 37} & 372106 & 0755620 & 165 & 38 & 17 & $11-01-74$ & VWCB \\
\hline & & & & & 14 & $11-28-78$ & VWCB \\
\hline & & & & & 13 & $02-26-79$ & VWCB \\
\hline & & & & & 15 & $05-02-79$ & VWCB \\
\hline & & & & & 13 & 08-20-79 & VWCB \\
\hline & & & & & 12 & $12-06-79$ & VWCB \\
\hline & & & & & 15 & $01-28-80$ & VWCB \\
\hline & & & & & 15 & $08-28-80$ & VWCB \\
\hline & & & & & 14 & $02-19-81$ & VWCB \\
\hline & & & & & 17 & 08-24-81 & VWCB \\
\hline & & & & & 36 & $07-21-82$ & VWCB \\
\hline & & & & & 16 & $06-16-83$ & VWCB \\
\hline & & & & & 14 & $07-23-84$ & VWCB \\
\hline \multirow[t]{5}{*}{$63 \mathrm{H} 5$} & 372705 & 0755559 & 132 & 17 & 24 & $09-28-77$ & VWCB \\
\hline & & & & & 24 & $05-11-79$ & VWCB \\
\hline & & & & & 24 & $06-26-84$ & VWCB \\
\hline & & & & & 28 & $01-25-88$ & USGS \\
\hline & & & & & 35 & $03-02-89$ & USGS \\
\hline $63 \mathrm{H} 10$ & 372412 & 0755415 & 152 & 38 & 15 & $12-18-80$ & VWCB \\
\hline $63 \mathrm{H} 11$ & 372608 & 0755307 & 180 & 30 & 15 & $12-18-80$ & VWCB \\
\hline \multirow[t]{2}{*}{$63 \mathrm{~J} 1$} & 373230 & 0755410 & 120 & 22 & 27 & $08-25-80$ & VWCB \\
\hline & & & & & 24 & $06-28-84$ & VWCB \\
\hline \multirow[t]{3}{*}{$64 \mathrm{H} 6$} & 372905 & 0754740 & 154 & 6 & 52 & $06-01-77$ & VWCB \\
\hline & & & & & 49 & $07-11-84$ & VwCB \\
\hline & & & & & 51 & 03-01-89 & USGS \\
\hline \multirow[t]{3}{*}{$64 \mathrm{~J} 2$} & 372235 & 0755335 & 190 & 34 & 14 & $10-27-69$ & USGS \\
\hline & & & & & 15 & 01-29-70 & USGS \\
\hline & & & & & 14 & $02-18-75$ & VWCB \\
\hline \multirow[t]{2}{*}{$64 \mathrm{~J} 9$} & 373059 & 0754845 & 135 & 30 & 11 & 07-03-79 & VwCB \\
\hline & & & & & 12 & $08-22-80$ & VWCB \\
\hline \multirow[t]{3}{*}{$64 \mathrm{~J} 18$} & 373503 & 0754920 & 167 & 31 & 13 & $02-01-75$ & VWCB \\
\hline & & & & & 10 & $08-01-78$ & VwCB \\
\hline & & & & & 10 & $02-19-81$ & VWCB \\
\hline $64 \mathrm{~J} 24$ & 373045 & 0754829 & 130 & 7 & 48 & 08-02-79 & VWCB \\
\hline
\end{tabular}


Table 9. Chloride concentrations in the upper Yorktown-Eastover aquifer-Continued

\begin{tabular}{|c|c|c|c|c|c|c|c|}
\hline $\begin{array}{l}\text { USGS } \\
\text { well } \\
\text { number }\end{array}$ & Latitude & Longitude & $\begin{array}{l}\text { Well } \\
\text { depth } \\
\text { (feet) }\end{array}$ & $\begin{array}{l}\text { Land- } \\
\text { surface } \\
\text { altitude } \\
\text { (feet) }\end{array}$ & $\begin{array}{l}\text { Chloride } \\
\text { concentration } \\
\text { (mg/L) }\end{array}$ & $\begin{array}{l}\text { Date } \\
\text { sampled }\end{array}$ & $\begin{array}{l}\text { Sampling } \\
\text { agency }\end{array}$ \\
\hline \multirow[t]{4}{*}{$64 \mathrm{~K} 8$} & 373845 & 0755225 & 95 & 3 & 33 & $09-21-77$ & VWCB \\
\hline & & & & & 41 & $08-20-80$ & VWCB \\
\hline & & & & & 47 & $06-26-84$ & VWCB \\
\hline & & & & & 34 & $03-02-89$ & USGS \\
\hline \multirow[t]{3}{*}{$64 \mathrm{~K} 11$} & 373932 & 0754527 & 180 & 47 & 10 & $08-20-80$ & VWCB \\
\hline & & & & & 9 & $06-29-84$ & VWCB \\
\hline & & & & & 8 & $01-26-88$ & USGS \\
\hline \multirow[t]{2}{*}{$65 \mathrm{~K} 6$} & 373830 & 0754000 & 190 & 43 & 10 & $10-21-71$ & USGS \\
\hline & & & & & 10 & $03-04-72$ & USGS \\
\hline \multirow[t]{2}{*}{$65 \mathrm{~K} 9$} & 374233 & 0754432 & 159 & 17 & 10 & $02-26-75$ & VWCB \\
\hline & & & & & 9 & $09-10-75$ & USGS \\
\hline \multirow[t]{8}{*}{$65 \mathrm{~K} 22$} & 374153 & 0754309 & 180 & 43 & 8 & $09-28-71$ & USGS \\
\hline & & & & & 8 & $03-06-80$ & VWCB \\
\hline & & & & & 8 & $02-19-81$ & VWCB \\
\hline & & & & & 5 & $08-24-81$ & VWCB \\
\hline & & & & & 10 & $02-11-82$ & VWCB \\
\hline & & & & & 4 & $09-28-82$ & VWCB \\
\hline & & & & & 9 & 03-29-84 & VWCB \\
\hline & & & & & 7 & $11-19-84$ & VWCB \\
\hline $65 \mathrm{~K} 24$ & 374442 & 0754325 & 130 & 12 & 7 & $08-13-80$ & VWCB \\
\hline \multirow[t]{2}{*}{ 65K 27} & 374425 & 0754000 & 160 & 45 & 10 & $02-13-80$ & VWCB \\
\hline & & & & & 9 & $07-09-84$ & VWCB \\
\hline \multirow[t]{7}{*}{$65 \mathrm{~L} 3$} & 373730 & 0754000 & 160 & 40 & 7 & $04-22-60$ & VWCB \\
\hline & & & & & 24 & $01-05-72$ & USGS \\
\hline & & & & & 24 & $03-07-72$ & USGS \\
\hline & & & & & 20 & $06-01-72$ & VWCB \\
\hline & & & & & 22 & $06-27-77$ & VWCB \\
\hline & & & & & 22 & $11-14-77$ & VWCB \\
\hline & & & & & 23 & $02-23-78$ & VWCB \\
\hline \multirow[t]{2}{*}{$66 \mathrm{~K} 4$} & 374320 & 0753656 & 152 & 10 & 8 & $06-03-77$ & VWCB \\
\hline & & & & & 8 & $07-10-84$ & VWCB \\
\hline \multirow[t]{2}{*}{$66 \mathrm{~L} 2$} & 375225 & 0753217 & 140 & 5 & 6 & $09-21-77$ & VWCB \\
\hline & & & & & 8 & $07-10-84$ & VWCB \\
\hline $66 \mathrm{~L}, 4$ & 374625 & 0753646 & 160 & 40 & 9 & $08-04-81$ & VWCB \\
\hline \multirow[t]{2}{*}{$66 \mathrm{M} 16$} & 375723 & 0753444 & 130 & 11 & 13 & $08-26-80$ & VWCB \\
\hline & & & & & 14 & $07-11-84$ & VWCB \\
\hline $60 \mathrm{M} 22$ & 375920 & 0753205 & 132 & 21 & 15 & $03-30-82$ & VWCB \\
\hline \multirow[t]{4}{*}{$67 \mathrm{M} 11$} & 375635 & 0752715 & 138 & 14 & 28 & $03-29-81$ & VWCB \\
\hline & & & & & 23 & $05-12-81$ & VWCB \\
\hline & & & & & 19 & $05-27-82$ & VWCB \\
\hline & & & & & 19 & $08-07-84$ & VWCB \\
\hline
\end{tabular}

freshwater, saltwater, or both freshwater and saltwater. Upward freshwater leakage is distributed between the saltwater and freshwater zones based on the volume of each type of water in the node receiving the leakage. If freshwater is leaking upward into a node that contains 80 -percent freshwater and 20 -percent saltwater, then 80 percent of the leakage will be incorporated into the freshwater zone and 20 percent of the leakage will be incorporated into the saltwater zone. If freshwater is leaking upward into a node that contains all saltwater, then all the freshwater leakage will be incorporated into the saltwater zone (Essaid, 1990a). Vertical leakage of saltwater into freshwater is not directly simulated; evidence of vertical saltwater intrusion is provided by examination of the hydraulic gradients and areas of reversed ground-water flow.

The sharp-interface modeling approach neglects hydrodynamic dispersion; therefore, the interface position does not represent a particular 
Table 10. Chloride concentrations in the middle Yorktown-Eastover aquifer

[USGS, U.S. Geological Survey; VWCB, Virginia Water Control Board; latitude and longitude are reported in degrees, arc minutes, arc seconds; $\mathrm{mg} / \mathrm{L}$, milligrams per liter]

\begin{tabular}{|c|c|c|c|c|c|c|c|}
\hline $\begin{array}{l}\text { USGS } \\
\text { well } \\
\text { number }\end{array}$ & Latitude & Longitude & $\begin{array}{l}\text { Well } \\
\text { depth } \\
\text { (feet) }\end{array}$ & $\begin{array}{l}\text { Land- } \\
\text { surface } \\
\text { altitude } \\
\text { (feet) }\end{array}$ & $\begin{array}{l}\text { Chloride } \\
\text { concentration } \\
(\mathrm{mg} / \mathrm{L})\end{array}$ & $\begin{array}{l}\text { Date } \\
\text { sampled }\end{array}$ & $\begin{array}{l}\text { Sampling } \\
\text { agency }\end{array}$ \\
\hline $62 \mathrm{~F} 2$ & 371456 & 0760030 & 210 & 12 & 12 & $12-01-77$ & USGS \\
\hline $62 \mathrm{G} 4$ & 372250 & 0755335 & 210 & 12 & 24 & $01-04-72$ & USGS \\
\hline 62G 8 & 371540 & 0760121 & 200 & 12 & 170 & $10-17-75$ & USGS \\
\hline 62G 9 & 371539 & 0760114 & 170 & 12 & 250 & $10-17-75$ & VWCB \\
\hline $62 \mathrm{G} 15$ & 371543 & 0760034 & 190 & 12 & 175 & $08-06-84$ & VWCB \\
\hline \multirow[t]{9}{*}{$62 \mathrm{G} 16$} & 371544 & 0760118 & 221 & 12 & 114 & $05-09-77$ & VWCB \\
\hline & & & & & 130 & $08-01-77$ & VWCB \\
\hline & & & & & 121 & $11-28-78$ & VWCB \\
\hline & & & & & 124 & $01-28-80$ & VWCB \\
\hline & & & & & 144 & $02-19-81$ & VWCB \\
\hline & & & & & 129 & $07-22-82$ & VWCB \\
\hline & & & & & 161 & $02-28-83$ & VWCB \\
\hline & & & & & 147 & $01-23-84$ & VWCB \\
\hline & & & & & 171 & $05-15-85$ & VWCB \\
\hline \multirow[t]{2}{*}{$63 \mathrm{~F} 10$} & 371057 & 0755814 & 220 & 27 & 14 & $09-11-75$ & USGS \\
\hline & & & & & 15 & $02-01-75$ & VWCB \\
\hline \multirow[t]{2}{*}{$63 \mathrm{~F} 17$} & 371307 & 0755835 & 196 & 31 & 13 & $08-01-80$ & VWCB \\
\hline & & & & & 11 & $07-12-84$ & VWCB \\
\hline \multirow[t]{6}{*}{$63 G 16$} & 371709 & 0755608 & 240 & 28 & 72 & $10-03-77$ & VWCB \\
\hline & & & & & 20 & $08-18-79$ & VWCB \\
\hline & & & & & 31 & $09-26-79$ & VWCB \\
\hline & & & & & 15 & $08-06-84$ & VWCB \\
\hline & & & & & 14 & $01-25-88$ & USGS \\
\hline & & & & & 14 & $02-28-89$ & USGS \\
\hline 63G 27 & 371710 & 0755522 & 185 & 5 & 18 & $08-25-80$ & VWCB \\
\hline \multirow[t]{3}{*}{ 63G 34} & 371715 & 0755521 & 186 & 3 & 19 & $09-23-81$ & VWCB \\
\hline & & & & & 15 & $07-22-82$ & VWCB \\
\hline & & & & & 17 & $03-14-83$ & VWCB \\
\hline \multirow[t]{2}{*}{ 63G 35} & 371715 & 0755521 & 186 & 5 & 25 & $04-07-75$ & VWCB \\
\hline & & & & & 17 & $10-16-81$ & VWCB \\
\hline \multirow[t]{3}{*}{ 63G 36} & 371711 & 0755524 & 185 & 6 & 19 & $02-12-75$ & VWCB \\
\hline & & & & & 16 & $04-01-75$ & VWCB \\
\hline & & & & & 15 & $03-26-80$ & VWCB \\
\hline $63 G 43$ & 371620 & 0755815 & 215 & 15 & 11 & 03-03-89 & VWCB \\
\hline 63J 2 & 373230 & 0755410 & 225 & 22 & 1,400 & $08-06-86$ & VWCB \\
\hline \multirow[t]{5}{*}{$64 \mathrm{H} 7$} & 372905 & 0754740 & 220 & 6 & 400 & $06-01-77$ & VWCB \\
\hline & & & & & 340 & $07-11-84$ & VWCB \\
\hline & & & & & 400 & $08-05-86$ & VWCB \\
\hline & & & & & 430 & $11-12-87$ & USGS \\
\hline & & & & & 350 & 03-01-89 & USGS \\
\hline $64 \mathrm{H} 9$ & 372830 & 0755132 & 245 & 37 & 10 & $05-11-84$ & VWCB \\
\hline \multirow[t]{4}{*}{ 64J 7} & 372245 & 0755335 & 228 & 34 & 17 & $06-02-65$ & VWCB \\
\hline & & & & & 15 & $09-10-70$ & VWCB \\
\hline & & & & & 12 & $12-19-72$ & VWCB \\
\hline & & & & & 15 & $11-12-74$ & VWCB \\
\hline \multirow[t]{3}{*}{ 64J 10} & 373059 & 0754845 & 210 & 30 & 36 & 07-03-79 & VWCB \\
\hline & & & & & 35 & $08-21-80$ & VWCB \\
\hline & & & & & 35 & $02-22-88$ & USGS \\
\hline $64 \mathrm{~J} 17$ & 373507 & 0755155 & 180 & 30 & 10 & $08-07-81$ & VWCB \\
\hline \multirow[t]{3}{*}{ 64J 21} & 373159 & 0754915 & 229 & 35 & 208 & $03-01-67$ & VWCB \\
\hline & & & & & 41 & $09-19-78$ & VWCB \\
\hline & & & & & 53 & 08-01-79 & VWCB \\
\hline $64 \mathrm{~J} 23$ & 373146 & 0755047 & 190 & 28 & 10 & $08-31-81$ & VWCB \\
\hline $64 \mathrm{~K} 3$ & 373756 & 0754906 & 210 & 25 & 12 & $12-31-06$ & USGS \\
\hline
\end{tabular}


Table 10. Chloride concentrations in the middle Yorktown-Eastover aquifer-Continued

\begin{tabular}{|c|c|c|c|c|c|c|c|}
\hline $\begin{array}{l}\text { USGS } \\
\text { well } \\
\text { number }\end{array}$ & Latitude & Longitude & $\begin{array}{l}\text { Well } \\
\text { depth } \\
\text { (feet) }\end{array}$ & $\begin{array}{l}\text { Land- } \\
\text { surface } \\
\text { altitude } \\
\text { (feet) }\end{array}$ & $\begin{array}{l}\text { Chloride } \\
\text { concentration } \\
(\mathrm{mg} / \mathrm{L})\end{array}$ & $\begin{array}{l}\text { Date } \\
\text { sampled }\end{array}$ & $\begin{array}{l}\text { Sampling } \\
\text { agency }\end{array}$ \\
\hline $64 \mathrm{~K} 21$ & 374029 & 0754925 & 185 & 6 & 17 & 02-02-89 & USGS \\
\hline 64L 1 & 374559 & 0754515 & 135 & 5 & 69 & 02-02-89 & USGS \\
\hline \multirow[t]{2}{*}{$65 K 28$} & 374425 & 0754000 & 230 & 45 & 15 & $02-13-80$ & VWCB \\
\hline & & & & & 12 & $07-09-84$ & VWCB \\
\hline $65 \mathrm{~K} 34$ & 373904 & 0754034 & 218 & 9 & 11 & $07-08-75$ & VWCB \\
\hline $65 \mathrm{~K} 42$ & 373750 & 0754415 & 225 & 41 & 9 & $02-02-89$ & USGS \\
\hline $65 L 9$ & 374931 & 0753908 & 155 & 3 & 8 & $02-02-89$ & USGS \\
\hline $65 \mathrm{~L} 12$ & 374809 & 0753818 & 220 & 36 & 9 & $02-02-89$ & USGS \\
\hline $65 \mathrm{M} 1$ & 375537 & 0754318 & 115 & 3 & 14 & $08-18-48$ & USGS \\
\hline \multirow{3}{*}{$65 \mathrm{M} 2$} & 375512 & 0754348 & 115 & 5 & 66 & 02-28-75 & VWCB \\
\hline & & & & & 65 & $03-25-75$ & VWCB \\
\hline & & & & & 67 & 09-08-75 & VWCB \\
\hline \multirow[t]{2}{*}{$66 \mathrm{~K} 3$} & 374320 & 0753656 & 220 & 8 & 16 & $06-03-77$ & VWCB \\
\hline & & & & & 8 & $07-10-84$ & VWCB \\
\hline \multirow[t]{3}{*}{$66 \mathrm{~L} 3$} & 375225 & 0753217 & 206 & 5 & 5 & $09-30-77$ & VWCB \\
\hline & & & & & 9 & $07-10-84$ & VWCB \\
\hline & & & & & 8 & $02-02-88$ & VWCB \\
\hline \multirow[t]{2}{*}{$66 \mathrm{~L} 6$} & 374900 & 0753524 & 246 & 53 & 10 & $08-09-78$ & VWCB \\
\hline & & & & & 10 & $10-08-81$ & VWCB \\
\hline \multirow{3}{*}{$66 \mathrm{M} 17$} & 375723 & 0753444 & 178 & 11 & 66 & $08-26-80$ & VWCB \\
\hline & & & & & 68 & $07-11-84$ & VWCB \\
\hline & & & & & 82 & $11-05-86$ & VWCB \\
\hline $60 \mathrm{M} 20$ & 375332 & 0753300 & 240 & 42 & 8 & $08-04-81$ & VWCB \\
\hline $66 \mathrm{M} 39$ & 375623 & 0753019 & 180 & 25 & 7 & $02-02-89$ & USGS \\
\hline \multirow[t]{11}{*}{$67 M 9$} & 375626 & 0752723 & 256 & 19 & 125 & $02-27-75$ & VWCB \\
\hline & & & & & 124 & $04-06-76$ & VWCB \\
\hline & & & & & 107 & $07-12-76$ & VWCB \\
\hline & & & & & 123 & $10-12-76$ & VWCB \\
\hline & & & & & 129 & 04-08-77 & VWCB \\
\hline & & & & & 141 & $11-14-77$ & VWCB \\
\hline & & & & & 164 & $04-21-81$ & VWCB \\
\hline & & & & & 173 & $12-14-81$ & VWCB \\
\hline & & & & & 167 & $05-27-82$ & VWCB \\
\hline & & & & & 171 & $07-22-82$ & VWCB \\
\hline & & & & & 183 & $01-25-83$ & VWCB \\
\hline \multirow[t]{5}{*}{$67 \mathrm{M} 12$} & 375635 & 0752715 & 222 & 13 & 79 & $03-29-81$ & VWCB \\
\hline & & & & & $\pi$ & $05-05-81$ & VWCB \\
\hline & & & & & 73 & $05-27-82$ & VWCB \\
\hline & & & & & 78 & $08-07-84$ & VWCB \\
\hline & & & & & 81 & $11-06-86$ & VWCB \\
\hline \multirow[t]{4}{*}{$67 \mathrm{M} 13$} & 375635 & 0752715 & 249 & 16 & 135 & $03-29-81$ & VWCB \\
\hline & & & & & 129 & $05-27-82$ & VWCB \\
\hline & & & & & 135 & $08-07-84$ & VWCB \\
\hline & & & & & 137 & $11-06-86$ & VWCB \\
\hline \multirow[t]{4}{*}{$67 \mathrm{M} 14$} & 375617 & 0752737 & 280 & 26 & 134 & $05-27-82$ & VWCB \\
\hline & & & & & 144 & 08-07-84 & VWCB \\
\hline & & & & & 142 & $11-06-86$ & VWCB \\
\hline & & & & & 140 & $01-26-88$ & USGS \\
\hline \multirow[t]{7}{*}{$67 \mathrm{M} 24$} & 375639 & 0752859 & 245 & 24 & 62 & $02-01-65$ & VWCB \\
\hline & & & & & 68 & $10-27-69$ & USGS \\
\hline & & & & & 64 & $07-01-70$ & VWCB \\
\hline & & & & & 64 & 06-01-71 & USGS \\
\hline & & & & & 65 & $06-01-72$ & VWCB \\
\hline & & & & & 56 & $02-27-75$ & VWCB \\
\hline & & & & & 74 & $04-05-81$ & VWCB \\
\hline
\end{tabular}


Table 11. Chloride concentrations in the lower Yorktown-Eastover aquifer

[USGS, U.S. Geological Survey; VWCB, Virginia Water Control Board; latitude and longitude are reported in degrees, arc minutes, arc seconds; $\mathrm{mg} / \mathrm{L}$, milligrams per liter]

\begin{tabular}{|c|c|c|c|c|c|c|c|}
\hline $\begin{array}{l}\text { USGS } \\
\text { well } \\
\text { number }\end{array}$ & Latitude & Longitude & $\begin{array}{l}\text { Well } \\
\text { depth } \\
\text { (feet) }\end{array}$ & $\begin{array}{l}\text { Land- } \\
\text { surface } \\
\text { alititude } \\
\text { (feet) }\end{array}$ & $\begin{array}{l}\text { Chloride } \\
\text { concentration } \\
(\mathrm{mg} / \mathrm{L})\end{array}$ & $\begin{array}{l}\text { Date } \\
\text { sampled }\end{array}$ & $\begin{array}{l}\text { Sampling } \\
\text { agency }\end{array}$ \\
\hline 62F 1 & 371457 & 0760028 & 260 & 12 & 358 & $01-01-78$ & VWCB \\
\hline \multirow[t]{4}{*}{ 63F 16} & 371307 & 0755835 & 285 & 31 & 75 & $08-11-80$ & VWCB \\
\hline & & & & & 73 & $07-12-84$ & VWCB \\
\hline & & & & & $\pi$ & 08-04-86 & VWCB \\
\hline & & & & & 92 & $09-27-87$ & VWCB \\
\hline \multirow[t]{3}{*}{$63 G 15$} & 371709 & 0755608 & 310 & 28 & 148 & $08-06-84$ & VWCB \\
\hline & & & & & 130 & $08-04-86$ & VWCB \\
\hline & & & & & 130 & $02-28-89$ & USGS \\
\hline \multirow[t]{5}{*}{$63 G 23$} & 371653 & 0755848 & 280 & 15 & 28 & $06-29-79$ & VWCB \\
\hline & & & & & 9 & $08-19-80$ & VWCB \\
\hline & & & & & 8 & $07-12-84$ & VWCB \\
\hline & & & & & 9 & $01-25-88$ & USGS \\
\hline & & & & & 9 & 03-01-89 & USGS \\
\hline \multirow[t]{6}{*}{$63 G 24$} & 371653 & 0755848 & 330 & 15 & 387 & $06-29-79$ & VWCB \\
\hline & & & & & 640 & $08-11-80$ & VWCB \\
\hline & & & & & 630 & $07-12-84$ & VWCB \\
\hline & & & & & 750 & 08-04-86 & VWCB \\
\hline & & & & & 730 & $11-10-87$ & USGS \\
\hline & & & & & 630 & 03-01-89 & USGS \\
\hline \multirow[t]{5}{*}{$63 \mathrm{H} 4$} & 372705 & 0755559 & 235 & 17 & 297 & $09-28-77$ & VWCB \\
\hline & & & & & 244 & $05-10-79$ & VWCB \\
\hline & & & & & 246 & $06-26-84$ & VWCB \\
\hline & & & & & 262 & $08-04-86$ & VWCB \\
\hline & & & & & 290 & $03-02-89$ & USGS \\
\hline \multirow[t]{7}{*}{$63 \mathrm{H} 8$} & 372620 & 0755255 & 295 & 33 & 13 & $05-02-79$ & VWCB \\
\hline & & & & & 10 & $11-28-79$ & VWCB \\
\hline & & & & & 12 & $02-19-81$ & VWCB \\
\hline & & & & & 12 & $07-21-82$ & VWCB \\
\hline & & & & & 14 & $09-12-83$ & VWCB \\
\hline & & & & & 12 & $08-23-84$ & VWCB \\
\hline & & & & & 12 & $02-19-85$ & VWCB \\
\hline \multirow[t]{2}{*}{$63 \mathrm{~J} 3$} & 373230 & 0755410 & 290 & 22 & 4,850 & $06-28-84$ & VWCB \\
\hline & & & & & 6,200 & $11-18-87$ & USGS \\
\hline \multirow[t]{4}{*}{$64 \mathrm{H} 5$} & 372922 & 0764701 & 306 & 6 & 2,217 & $06-01-77$ & VWCB \\
\hline & & & & & 2,150 & $07-11-84$ & VWCB \\
\hline & & & & & 2,350 & $08-05-86$ & VWCB \\
\hline & & & & & 2,100 & $11-12-87$ & USGS \\
\hline \multirow[t]{3}{*}{$64 \mathrm{~J} 11$} & 373059 & 0754845 & 313 & 30 & 1,598 & 07-03-79 & VWCB \\
\hline & & & & & 1,510 & $08-21-80$ & VWCB \\
\hline & & & & & 1,900 & $11-10-87$ & USGS \\
\hline 64J 15 & 373642 & 0754608 & 264 & 39 & 11 & $08-07-81$ & VWCB \\
\hline 64J 16 & 373705 & 0754550 & 262 & 40 & 8 & $08-07-81$ & VWCB \\
\hline \multirow[t]{2}{*}{$64 \mathrm{R} 5$} & 373828 & 0754509 & 290 & 45 & 7 & $02-28-75$ & VWCB \\
\hline & & & & & 9 & $09-11-75$ & USGS \\
\hline \multirow[t]{5}{*}{$64 \mathrm{~K} 7$} & 373845 & 0755225 & 176 & 8 & 320 & $09-30-77$ & VWCB \\
\hline & & & & & 318 & $08-20-80$ & VWCB \\
\hline & & & & & 306 & $06-26-84$ & VWCB \\
\hline & & & & & 300 & $08-05-86$ & VWCB \\
\hline & & & & & 310 & $03-02-89$ & USGS \\
\hline
\end{tabular}


Table 11. Chloride concentrations in the lower Yorktown-Eastover aquifer-Continued

\begin{tabular}{|c|c|c|c|c|c|c|c|}
\hline $\begin{array}{l}\text { USGS } \\
\text { well } \\
\text { number }\end{array}$ & Latitude & Longitude & $\begin{array}{l}\text { Well } \\
\text { depth } \\
\text { (feet) }\end{array}$ & $\begin{array}{l}\text { Land- } \\
\text { surface } \\
\text { altitude } \\
\text { (feet) }\end{array}$ & $\begin{array}{l}\text { Chloride } \\
\text { concentration } \\
(\mathrm{mg} / \mathrm{L})\end{array}$ & $\begin{array}{l}\text { Date } \\
\text { sampled }\end{array}$ & $\begin{array}{l}\text { Sampling } \\
\text { agency }\end{array}$ \\
\hline \multirow[t]{3}{*}{$64 \mathrm{~K} 12$} & 373932 & 0754527 & 284 & 47 & 12 & $08-21-80$ & VWCB \\
\hline & & & & & 12 & $06-29-84$ & VWCB \\
\hline & & & & & 11 & $01-26-88$ & USGS \\
\hline \multirow[t]{2}{*}{$65 \mathrm{~K} 7$} & 373805 & 0754000 & 295 & 36 & 43 & $09-21-71$ & USGS \\
\hline & & & & & 12 & $02-20-75$ & VWCB \\
\hline \multirow[t]{2}{*}{$65 K 18$} & 373800 & 0754000 & 283 & 40 & 37 & $09-20-71$ & USGS \\
\hline & & & & & 33 & $02-27-75$ & VWCB \\
\hline $65 \mathrm{~K} 20$ & 373810 & 0754000 & 295 & 43 & 55 & $09-21-71$ & USGS \\
\hline \multirow[t]{2}{*}{$65 \mathrm{~K} 23$} & 374442 & 0754325 & 290 & 13 & 515 & $08-13-80$ & VWCB \\
\hline & & & & & 800 & $02-01-88$ & USGS \\
\hline \multirow[t]{2}{*}{$65 \mathrm{~K} 25$} & 374442 & 0754325 & 228 & 12 & 9 & $08-13-80$ & VWCB \\
\hline & & & & & 15 & $01-27-88$ & USGS \\
\hline \multirow[t]{3}{*}{$65 \mathrm{~K} 29$} & 374425 & 0754000 & 315 & 45 & 10 & $08-26-80$ & VWCB \\
\hline & & & & & 226 & $07-09-84$ & VWCB \\
\hline & & & & & 320 & $11-11-87$ & USGS \\
\hline \multirow[t]{4}{*}{$65 \mathrm{M} 3$} & 375512 & 0754348 & 195 & 5 & 430 & $02-01-75$ & VWCB \\
\hline & & & & & 330 & $01-28-80$ & VWCB \\
\hline & & & & & 343 & $01-20-82$ & VWCB \\
\hline & & & & & 398 & $04-17-85$ & VWCB \\
\hline \multirow[t]{3}{*}{$66 \mathrm{~K} 2$} & 374320 & 0753805 & 292 & 10 & 130 & 06-03-84 & VWCB \\
\hline & & & & & 45 & $08-06-86$ & VWCB \\
\hline & & & & & 9 & $01-27-88$ & USGS \\
\hline \multirow[t]{3}{*}{$66 L 1$} & 375225 & 0753217 & 305 & 5 & 16 & $09-15-77$ & VWCB \\
\hline & & & & & 12 & $07-10-84$ & VWCB \\
\hline & & & & & 14 & $02-01-88$ & USGS \\
\hline \multirow[t]{11}{*}{$66 \mathrm{M} 5$} & 375239 & 0753529 & 246 & 17 & 17 & $04-06-55$ & USGS \\
\hline & & & & & 16 & $02-26-76$ & VWCB \\
\hline & & & & & 25 & $03-23-76$ & VWCB \\
\hline & & & & & 15 & $06-03-76$ & VWCB \\
\hline & & & & & 19 & $08-31-76$ & VWCB \\
\hline & & & & & 24 & $12-02-76$ & VWCB \\
\hline & & & & & 18 & $03-31-77$ & VWCB \\
\hline & & & & & 23 & $05-31-77$ & VWCB \\
\hline & & & & & 18 & $09-15-77$ & VWCB \\
\hline & & & & & 19 & $12-01-77$ & VWCB \\
\hline & & & & & 17 & $03-06-78$ & VWCB \\
\hline \multirow[t]{4}{*}{$60 \mathrm{M} 18$} & 375723 & 0753444 & 240 & 11 & 790 & $08-26-80$ & VWCB \\
\hline & & & & & 755 & $07-11-84$ & VWCB \\
\hline & & & & & 1,675 & $11-05-86$ & VWCB \\
\hline & & & & & 1,400 & $10-30-87$ & USGS \\
\hline \multirow[t]{2}{*}{$66 \mathrm{M} 25$} & 375610 & 0753618 & 340 & 6 & 2,100 & $10-30-87$ & USGS \\
\hline & & & & & 2,100 & 08-29-88 & USGS \\
\hline \multirow[t]{2}{*}{$69 \mathrm{M} 26$} & 375610 & 0753618 & 230 & 6 & 1,000 & $10-30-87$ & USGS \\
\hline & & & & & 810 & $08-29-88$ & USGS \\
\hline
\end{tabular}

chloride concentration. This approach is not intended to provide specific information concerning the physical and chemical nature of the transition zone between freshwater and saltwater. A more detailed examination of the transition zone would require knowledge of the dispersive characteristics of the aquifers. Comparisons between sharpinterface and disperse-interface solutions have shown that the sharp-interface toe tends to be farther inland than the actual transition zone because the effects of dispersion are neglected (Cooper, 1959; Kohout, 1964; Volker and Rushton, 1982; Hill, 1988). The modeled saltwater-freshwater sharp interface is a first attempt at understanding the saltwater-freshwater-flow dynamics; the sharp interface provides information concerning the general 


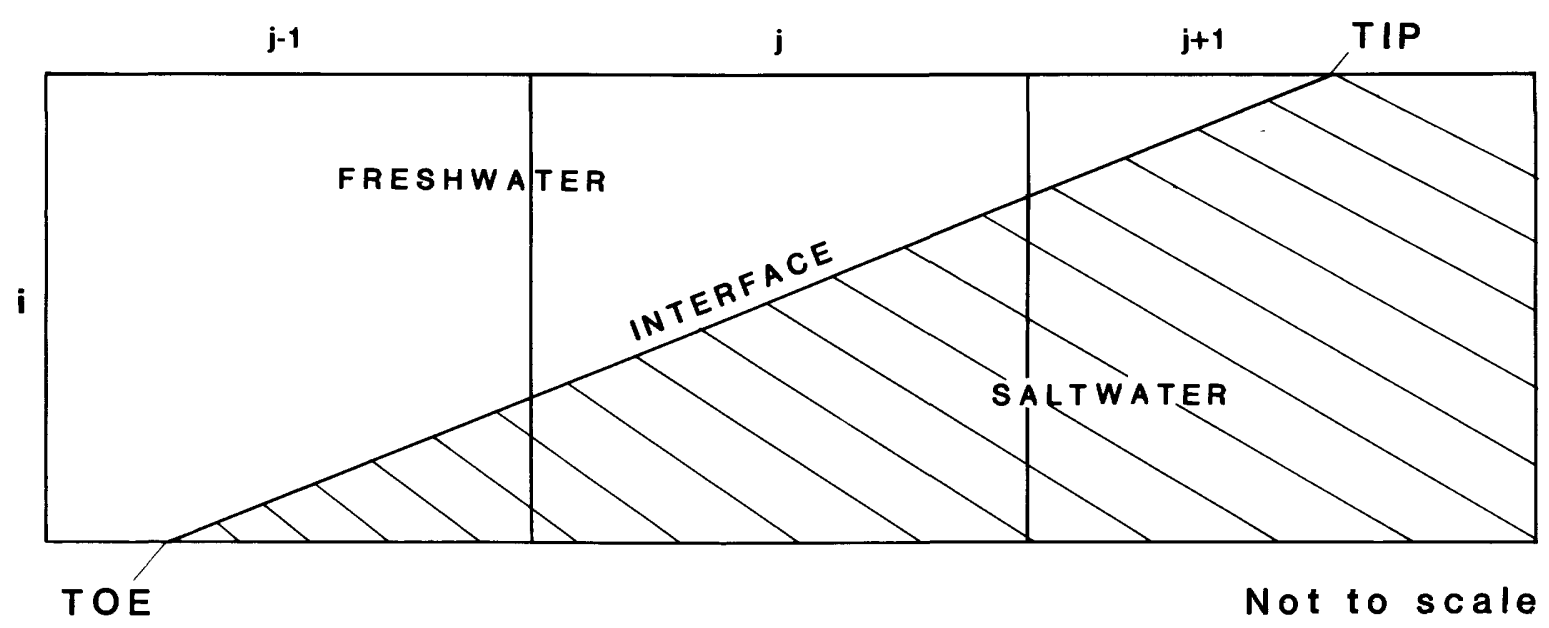

Figure 23. Model representation of the saltwater-freshwater interface tip and toe.

response of the interface to applied stresses. A derivation of the equations and a complete description of the solution algorithm are provided in Essaid (1990a).

\section{Model Grid and Boundaries}

The physical conceptualization of the groundwater-flow system is incorporated into a finitedifference model by dividing the system into a network of rectangular grid blocks (fig. 24). Each grid block is assigned values that represent the average aquifer characteristics and hydrologic stresses for that area. The spatial discretization for the Eastern Shore ground-water-flow model consists of a variable three-dimensional grid of 106 rows and 59 columns. The grid-block dimensions range from a minimum of $0.49 \mathrm{mi}$ to a maximum of $3.29 \mathrm{mi}$.

The model simulates flow only in the confined aquifers. Each of the three confined aquifers containing freshwater on the Eastern Shore was represented by a separate model layer. The unconfined aquifer was represented as a constant-head boundary overlying the confined-aquifer system. Confining units are not represented by layers but by vertical leakance terms assigned between layers. The physical and model conceptualizations of the groundwater-flow system are shown in figure 25. Model grid blocks can contain all freshwater, all saltwater, or both freshwater and saltwater. When the saltwater-freshwater interface passes through a grid block, the grid block contains both saltwater and freshwater.

The model boundaries are designed to approximate the actual physical system. The western, eastern, and southern boundaries for the Eastern Shore peninsula are the Chesapeake Bay and the Atlantic Ocean and are represented as no-flow boundaries in the digital flow model. The boundaries are located far enough offshore to include the nearshore saltwater-flow regime. The model simulates the position of the saltwater-freshwater interface boundary condition. The location of this boundary changes in response to changes in the saltwater-flow and freshwater-flow regimes. The Ghyben-Herzberg approximation was applied to current water-table head values for an initial estimate of the interface position (Heath, 1983). The lower boundary of the model is simulated as a no-flow boundary and approximates the contact between the lower Yorktown-Eastover aquifer and the 150- to $300-\mathrm{ft}-$ thick St. Marys confining unit. This contact also is the lower limit of the freshwater-flow system. The upper boundary of the model is simulated as a constant-head boundary that represents the long-term

Figure 24. Finite-difference grid and boundaries used in model analysis. 


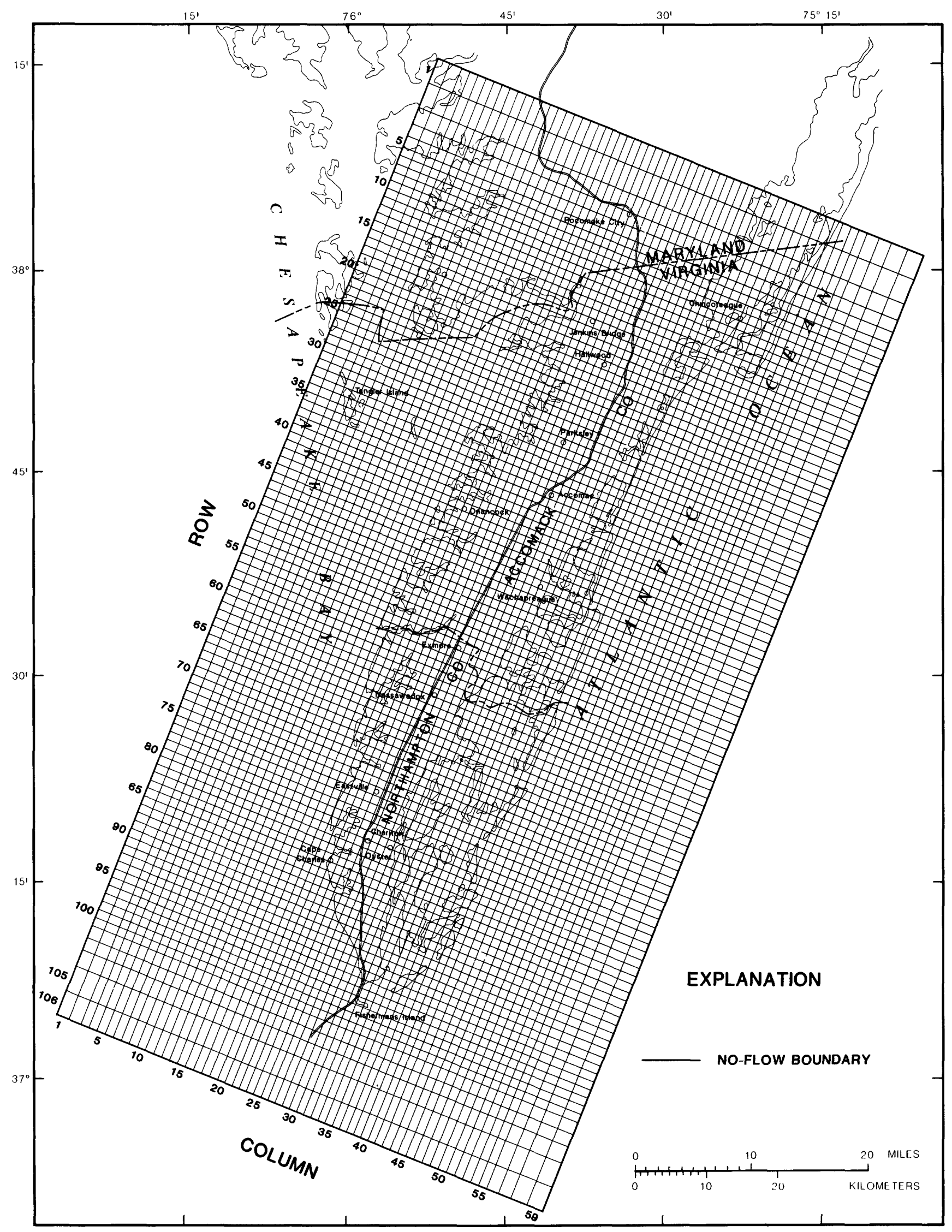




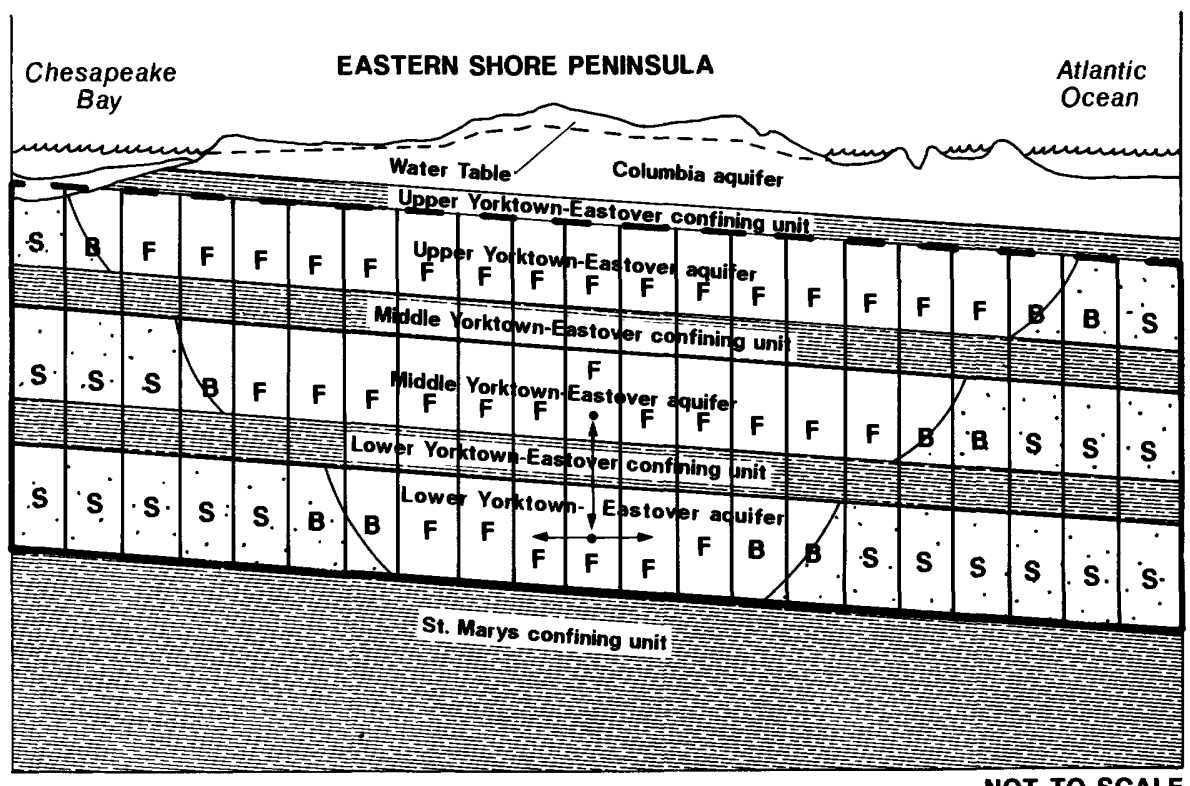

NOT TO SCALE

\section{EXPLANATION}
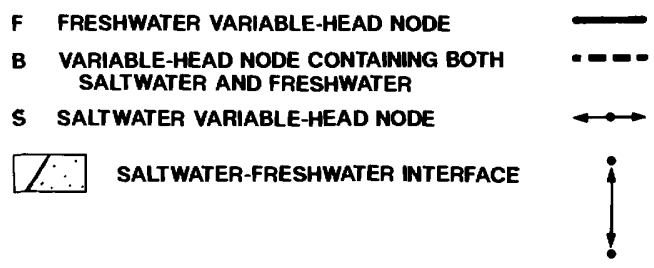

NO-FLOW BOUNDARY

CONSTANT-HEAD BOUNDARY-- REPRESENTS LONG-TERM HEADS IN COLUMBIA AQUIFER

DIRECTION OF FLOW WITHIN

AQUIFER (HORIZONTAL)

CONFINING-UNIT LEAKANCE (VERTICAL)

Figure 25. Physical and model conceptualizations of ground-water-flow system.

(quasi-steady-state) water table. This boundary is separated from the uppermost confined aquifer by a confining unit and represents the vertical connection between the unconfined-aquifer and the confinedaquifer system. The relative consistency of water levels in the unconfined aquifer over the time and scale of simulation supports the use of this boundary condition. Constant heads representing the average of the upper boundary in the onshore area were estimated from pond elevations, stream elevations, and water-level measurements in wells in the unconfined aquifer (fig. 26). Average elevations of surface water were estimated from USGS 7.5-min topographic maps. Heads in the offshore part of the upper boundary were calculated as the freshwater equivalent of the saltwater head as indicated from the bathymetry on USGS $1: 250,000$ scale topographic maps (fig. 11). The northern boundary is the only boundary that could not be delineated on the basis of a physical feature. Therefore, this boundary is extended beyond the study area, and an estimated flow line is represented by a no-flow boundary.

\section{Model Calibration}

The hydraulic properties of the aquifers and confining units are not uniform throughout the model area; therefore, the hydraulic characteristics are allowed to vary by assigning average values to each grid block. The hydraulic characteristics that vary spatially in this analysis are transmissivity, storage coefficient, and vertical leakance. Data quantifying these characteristics were not available for each grid block; values were estimated from available measurements of physical and hydrologic properties and laboratory analyses. A constant effective porosity of 0.25 was assigned to each model 


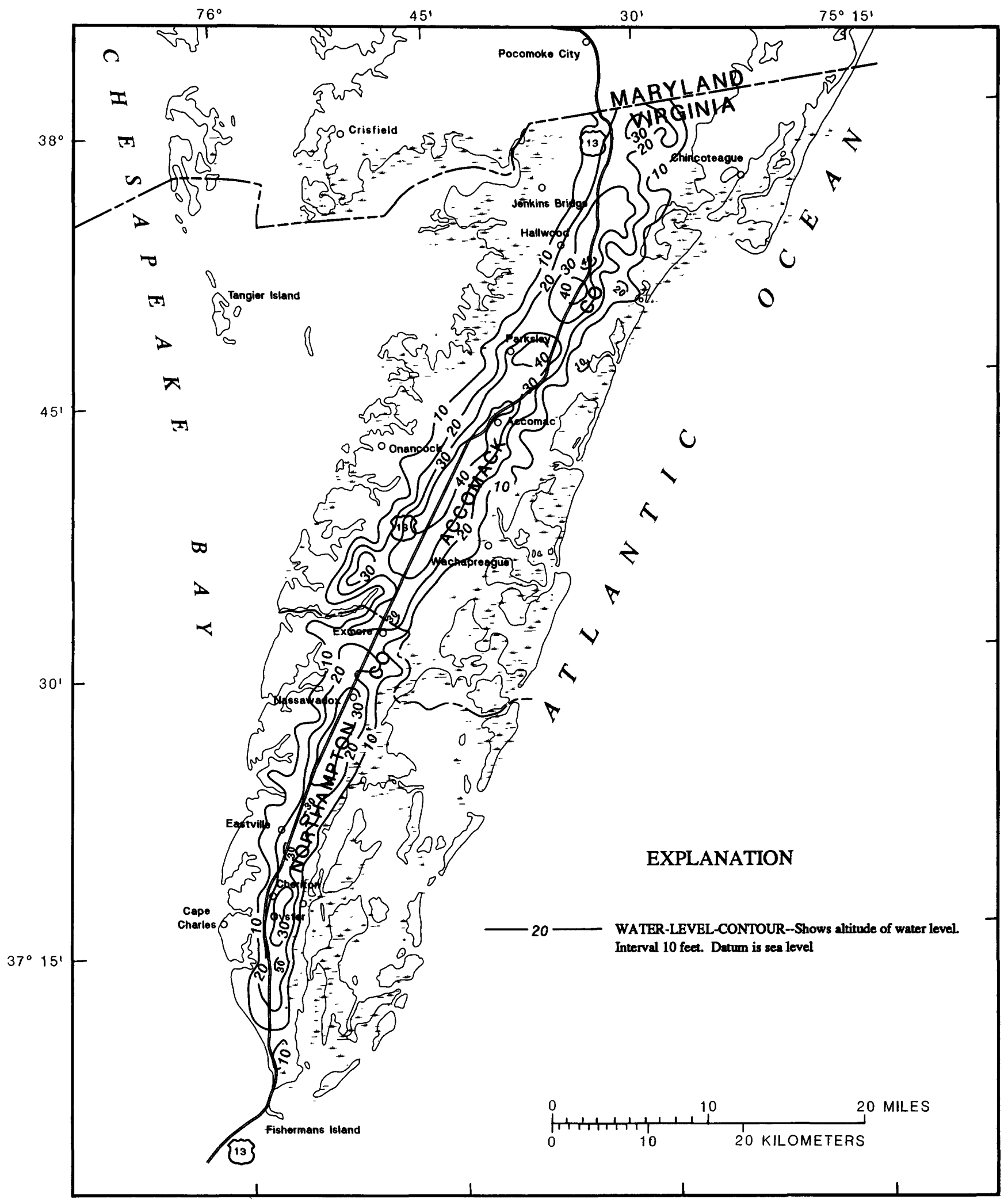

Figure 26. Average water levels for the Columbia aquifer. 
layer. Model-sensitivity analyses indicated that results were not sensitive to changes in effective porosity.

An iterative process was used to calibrate the ground-water-flow model. Initial estimates of hydraulic properties were used to run a steady-state simulation for prepumping conditions. The initial steady-state results were used as a starting point for a transient simulation of pumping conditions for the period 1940-88. The initial hydraulic properties were adjusted by comparing the simulated water levels to measured water levels. The process was repeated until simulated and measured water levels were in close agreement at all observation wells. The calibrated values used in the model analysis are stored on computer tapes at the Virginia District Office of the USGS in Richmond, Va.

\section{Transmissivity}

The transmissivity for each grid block is calculated by multiplying the average thickness of the aquifer by the average horizontal hydraulic conductivity of the aquifer. The average thickness of the aquifer was calculated for each grid block using maps of the tops of aquifers and confining units (figs. 3-9). Initial average horizontal hydraulic conductivities were estimated from specific-capacity and aquifer-test data. These initial values were adjusted slightly during the transient-model calibration. Actual horizontal hydraulic conductivity data are sparse; therefore, the values were held constant for each layer except in areas where major regional geologic changes could be discerned. The final horizontal hydraulic conductivities used in the model analysis are $51.6,43.2$, and $8.6 \mathrm{ft} / \mathrm{d}$ for the upper, middle, and lower Yorktown-Eastover aquifers, respectively (figs. 27-29). The horizontal hydraulic conductivity in the northwestern corner of the model area was reduced to $1.3 \mathrm{ft} / \mathrm{d}$ to reflect fine-grained sediments and reduced water-bearing capabilities in the western part of Somerset County, Md.

(Werkheiser, 1990). The horizontal hydraulic conductivity was also reduced 1 order of magnitude near Exmore and near Cape Charles in the middle Yorktown-Eastover aquifer $(4.3 \mathrm{ft} / \mathrm{d})$ to reflect the presence of Pleistocene paleochannels in which the original aquifer materials in these areas have been eroded and replaced by sediments with different hydraulic properties. A summary of the range of transmissivities estimated from specific-capacity data compared with the range of transmissivities used in the final model analysis is given in table 12 .

\section{Storage Coefficient}

The storage coefficient for each grid block was calculated by multiplying the estimated specific storage of the aquifer by the average saturated thickness of the aquifer. A constant specific storage of $1 \times 10^{-6} / \mathrm{ft}$ is used in the model analysis; the value for specific storage was not calibrated during model development. This value is commonly used in the literature to represent the specific storage of a confined aquifer and is considered reasonable if all water released from aquifer storage results from the compressibility of water (Lohman, 1979). The range of storage coefficients is listed by aquifer in table 13.

\section{Vertical Leakance}

The vertical leakance for each grid block was calculated by dividing the vertical hydraulic conductivity of the confining unit by the average thickness of the confining unit (figs. 3-9). A constant vertical hydraulic conductivity of $1.39 \times 10^{-5} \mathrm{ft} / \mathrm{d}$ from laboratory analysis of core samples (table 4 ) was used to calculate the initial vertical leakance used in the model calibration. Few core samples are available for the Eastern Shore; therefore, initial estimates were adjusted during transient-model development to estimate areal variations in vertical hydraulic conductivity. The range of final calibrated values for vertical leakance is listed by confining unit in table 14.

\section{Steady-State-Model Simulation of Prepumping Conditions}

Prior to 1940 , ground-water withdrawals on the Eastern Shore were minor. Ground-water use consisted of a relatively small number of users withdrawing small amounts of water. The ground-waterflow system at this time existed in an approximate state of hydraulic equilibrium (steady state). A steady-state-flow condition is reached when recharge to the system equals discharge from the system. This condition implies that the water levels are constant over time and that the change in storage in the ground-water system is negligible. A steadystate simulation was conducted using prepumping conditions for the Eastern Shore. The steady-state 


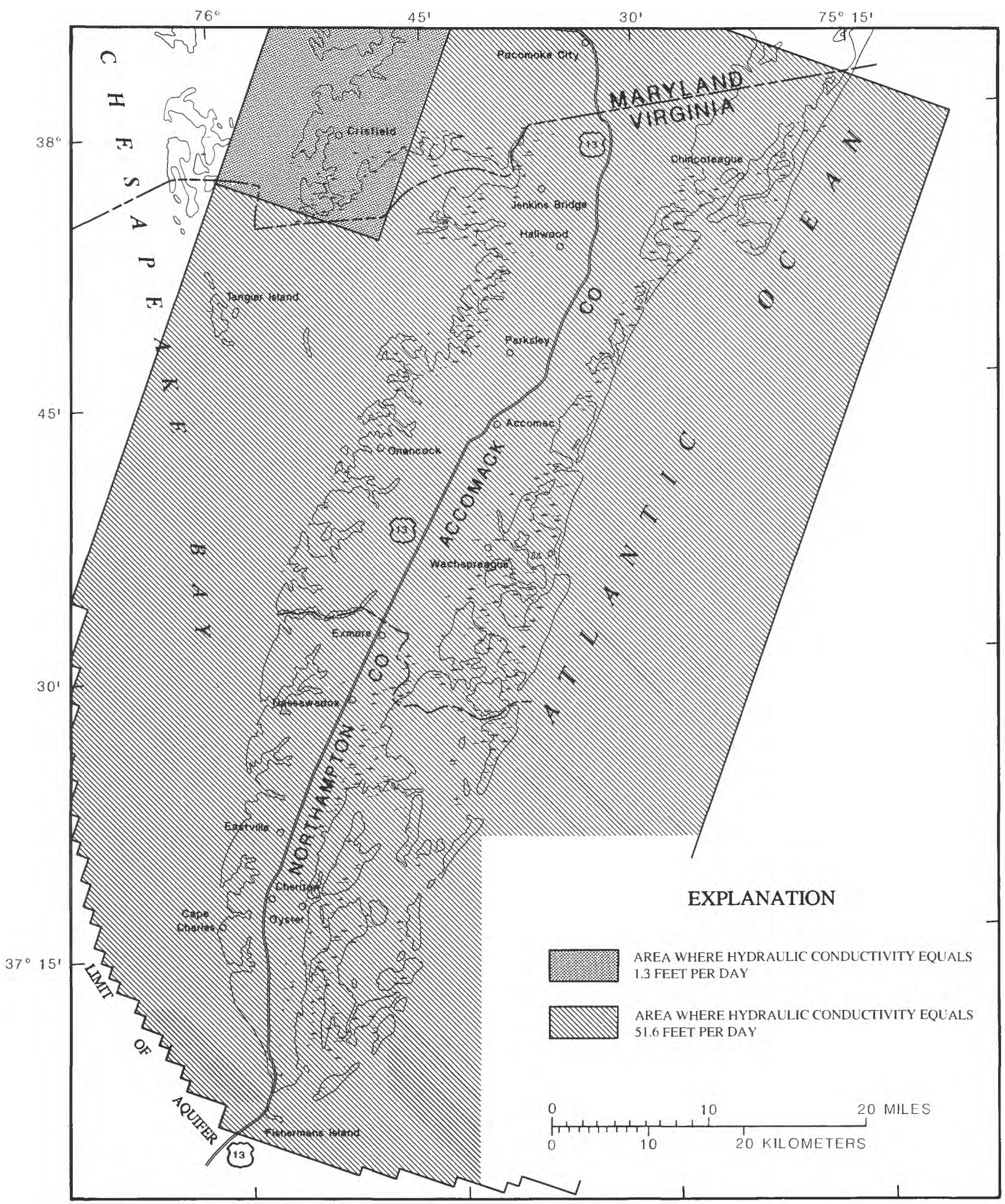

Figure 27. Hydraulic conductivity of the upper Yorktown-Eastover aquifer based on model calibration. 


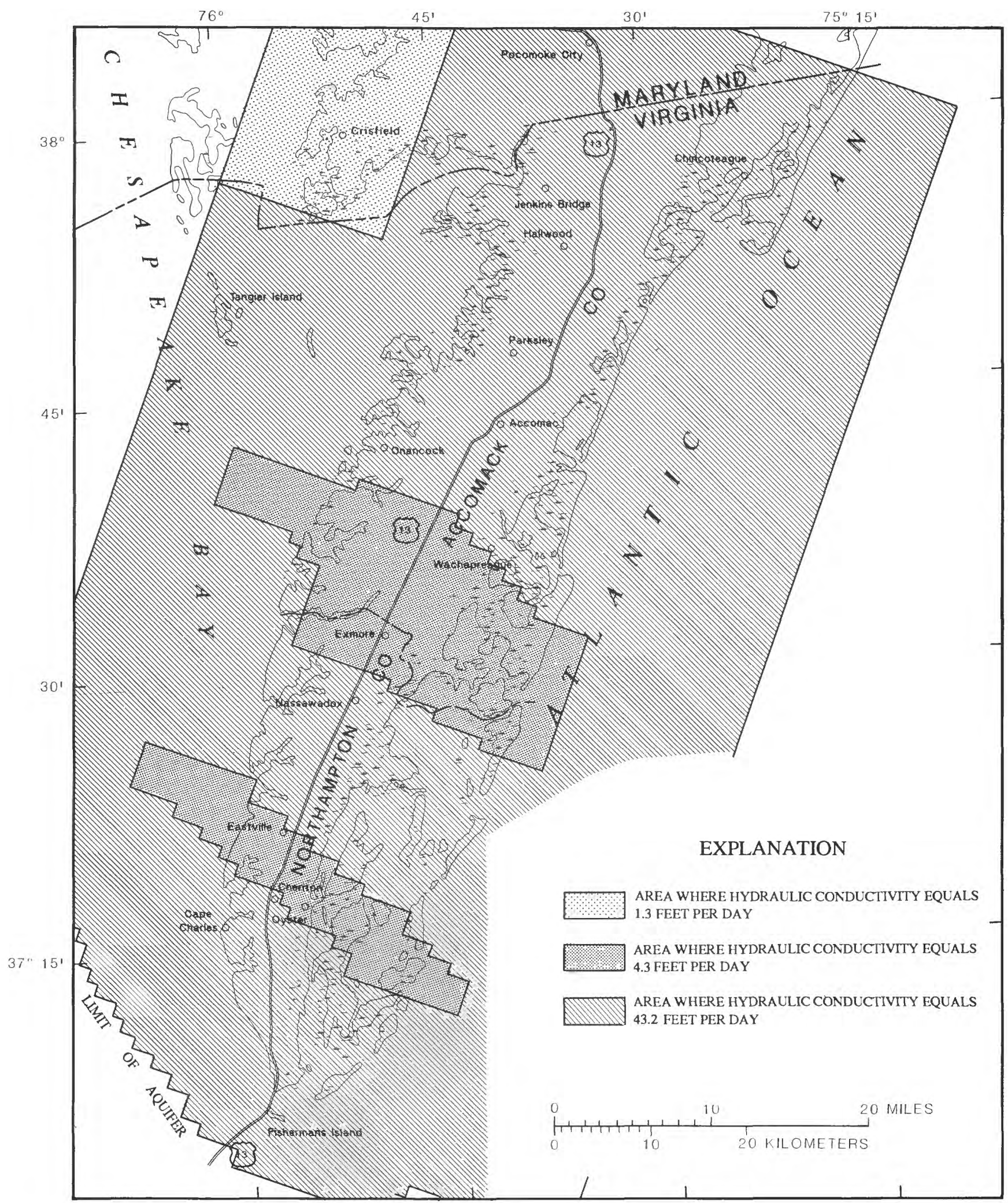

Figure 28. Hydraulic conductivity of the middle Yorktown-Eastover aquifer based on model calibration. 


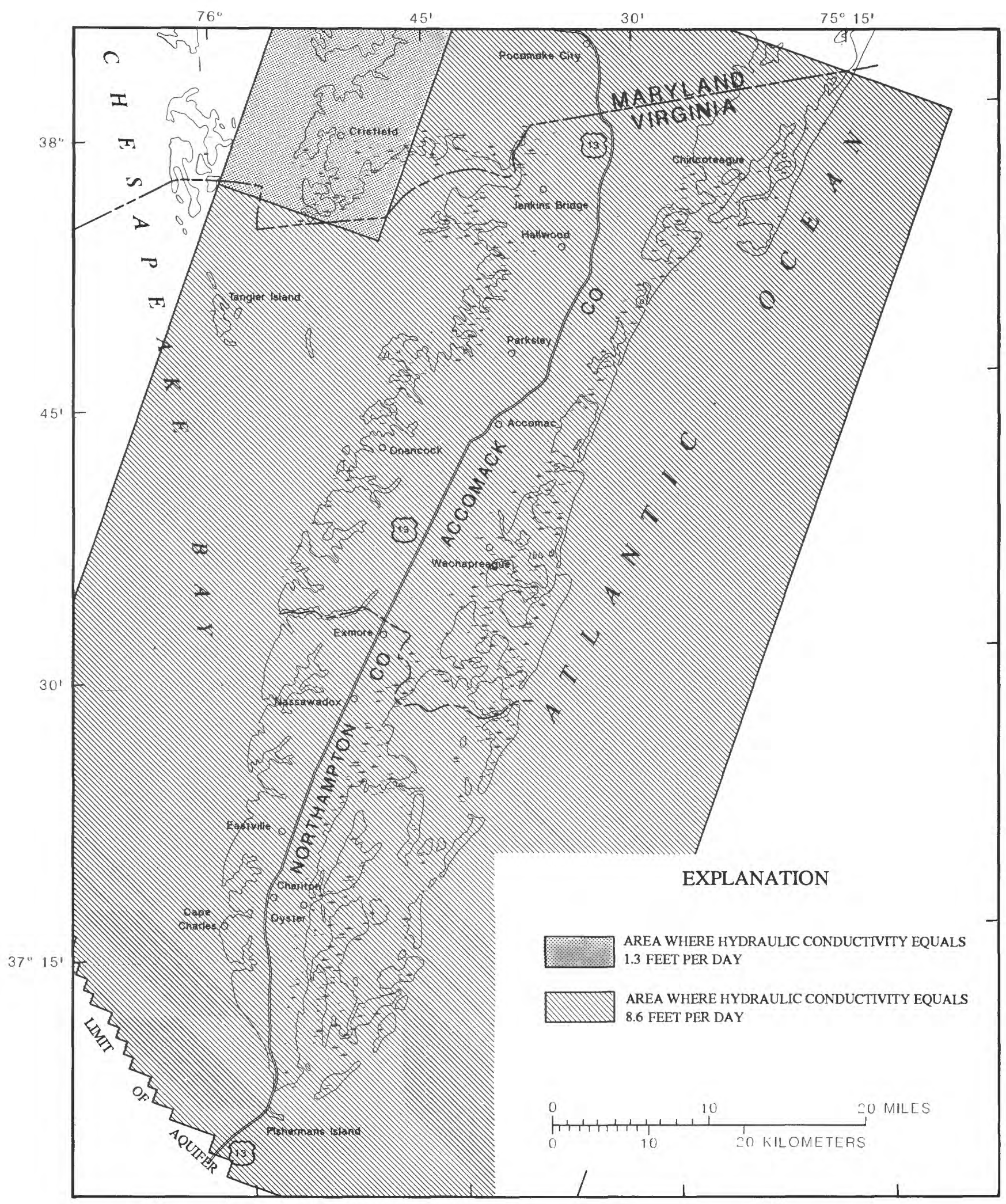

Figure 29. Hydraulic conductivity of the lower Yorktown-Eastover aquifer based on model calibration. 
Table 12. Range of transmissivities estimated from specific-capacity data and from model calibration $\left[\mathrm{ft}^{2} / \mathrm{d}\right.$, foot squared per day]

\begin{tabular}{lrc}
\hline & \multicolumn{2}{c}{ Estimated transmissivity $\left(\mathrm{ft}^{2} / \mathrm{d}\right)$} \\
\cline { 2 - 3 } Aquifer & Specific-capacity data & Model calibration \\
\hline & & \\
Upper Yorktown-Eastover & $61-4,530$ & $93-4,611$ \\
Middle Yorktown-Eastover & $206-3,240$ & $26-3,588$ \\
Lower Yorktown-Eastover & $95-2,094$ & $86-1,210$ \\
\hline
\end{tabular}

simulation is an approximation of the natural ground-water system prior to any major stresses, and it provides a starting point for transient simulations that examine the effects of increased groundwater withdrawals.

Simulated prepumping water levels for the Yorktown-Eastover aquifers are shown in figures 30-32. There are no reliable measurements of water levels for the confined aquifers on the Eastern Shore prior to 1940; however, the conceptualization of prepumping ground-water flow for the Eastern Shore assumes that water levels were a subdued replica of the land surface and that flow gradients were from topographic highs in the center of the peninsula to the Chesapeake Bay on the west and Atlantic Ocean on the east. Simulated water levels were compared with the prepumping water levels from a previous simulation of ground-water flow on the Eastern Shore (Bal, 1977). The simulated water levels and flow directions are consistent with Bal's study and are in agreement with the conceptualization of ground-water flow during prepumping conditions.

The calibration of the steady-state model was evaluated by analyzing estimates of rate of recharge. Simulated recharge to the confined system on the Eastern Shore was compared with results from a previous ground-water-modeling study in southeastern Virginia (Hamilton and Larson, 1988). The southeastern Virginia model of prepumping conditions estimated an average recharge rate to the confined-aquifer system of approximately $0.4 \mathrm{in} / \mathrm{yr}$. The Eastern Shore ground-water-flow model for prestressed conditions indicates a similar but slightly higher average recharge rate of approximately 0.6 in/yr. The recharge rate estimated in the steady-state calibration for the Eastern Shore model is consistent with a previous analysis of a similar system in the Coastal Plain of Virginia.
Table 13. Minimum and maximum values of model storage coefficient

[values, dimensionless, are not intended to imply accuracy to precision shown]

\begin{tabular}{lll}
\hline & \multicolumn{2}{c}{ Storage coefficient } \\
\cline { 2 - 3 } Aquifer & Minimum & Maximum \\
\hline Upper Yorktown-Eastover & $1.01 \times 10^{-5}$ & $1.52 \times 10^{-4}$ \\
Middle Yorktown-Eastover & $1.06 \times 10^{-5}$ & $8.31 \times 10^{-5}$ \\
Lower Yorktown-Eastover & $1.07 \times 10^{-5}$ & $1.83 \times 10^{-4}$ \\
\hline
\end{tabular}

Table 14. Minimum and maximum values of model vertical leakance

\begin{tabular}{llc}
\hline & \multicolumn{2}{c}{ Vertical leakance $\left(\right.$ days $\left.^{-1}\right)$} \\
\cline { 2 - 3 } Aquifer & Minimum & Maximum \\
\hline Upper Yorktown-Eastover & $4.32 \times 10^{-7}$ & $4.52 \times 10^{-4}$ \\
Middle Yorktown-Eastover & $8.55 \times 10^{-7}$ & $5.18 \times 10^{-4}$ \\
Lower Yorktown-Eastover & $1.24 \times 10^{-6}$ & $3.95 \times 10^{-4}$ \\
\hline
\end{tabular}

The simulated position of the tip and toe of the saltwater-freshwater interface for each of the Yorktown-Eastover aquifers for prepumping conditions is shown in figures 33-35. The position of the interface is a function of the freshwater-flow and saltwater-flow regimes. The interface generally is farthest offshore in the upper Yorktown-Eastover aquifer and is progressively farther inland in the middle and lower Yorktown-Eastover aquifers, where the depths to the aquifers increase and the freshwater heads decrease. The simulated position of the saltwater-freshwater interface in the steady-state simulation is an equilibrium position; the actual position of the prepumping saltwater-freshwater interface is not known. Several studies indicate that in some coastal areas the saltwater-freshwater interface is still responding to long-term Pleistocene sealevel fluctuations and has not achieved equilibrium with the present-day sea level (Essaid, 1990b; Meisler and others, 1985). It is assumed for the purposes of this study that the prepumping saltwaterfreshwater interface is in equilibrium with the present-day sea level. This approach provides a conservative estimate of saltwater-freshwater interface movement; a transitional interface would be moving landward because sea levels have been rising since the late Wisconsin glacial maximum (Meisler and others, 1985). The simulated prepumping position of 


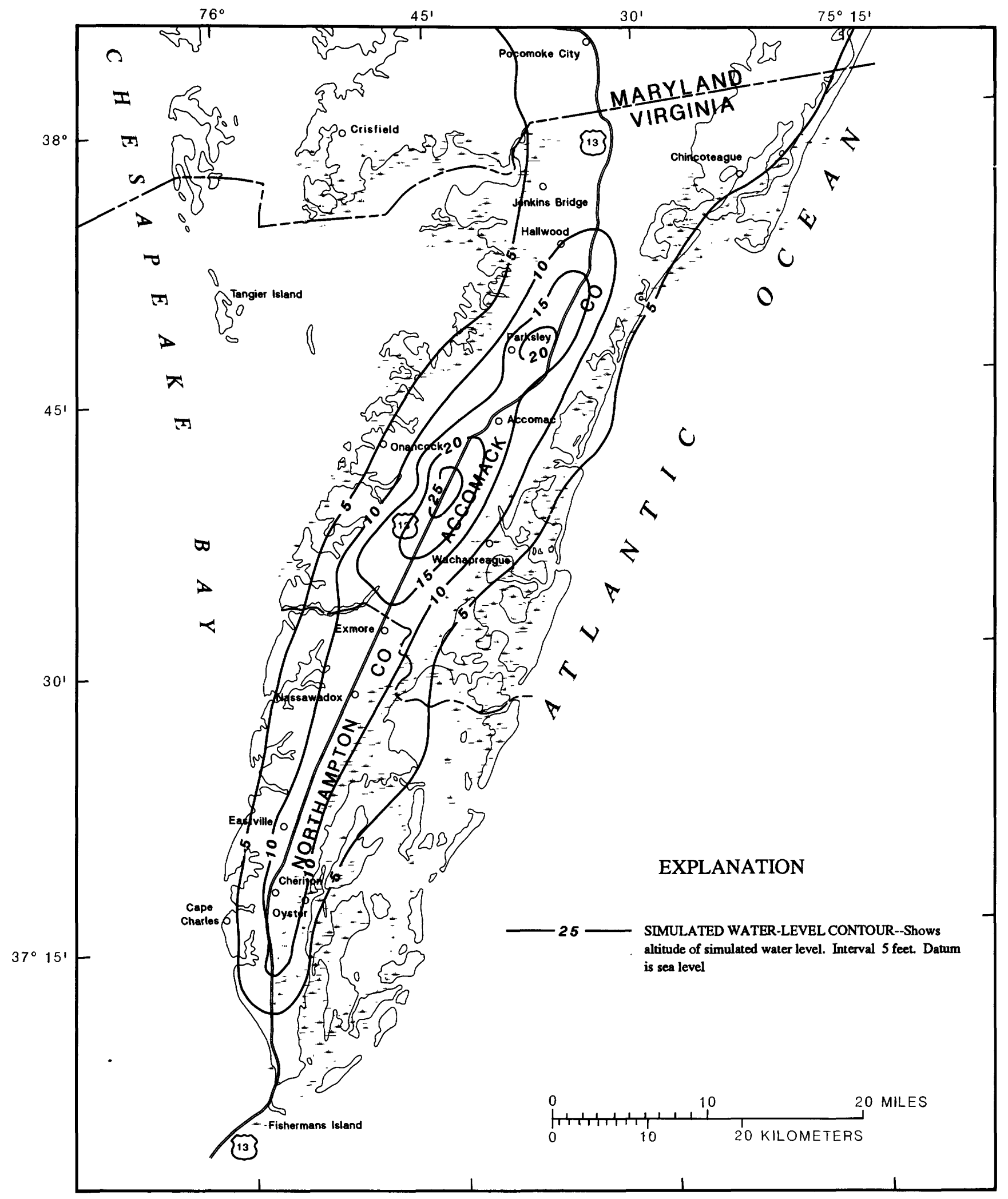

Figure 30. Simulated water levels in the upper Yorktown-Eastover aquifer for prepumping conditions. 


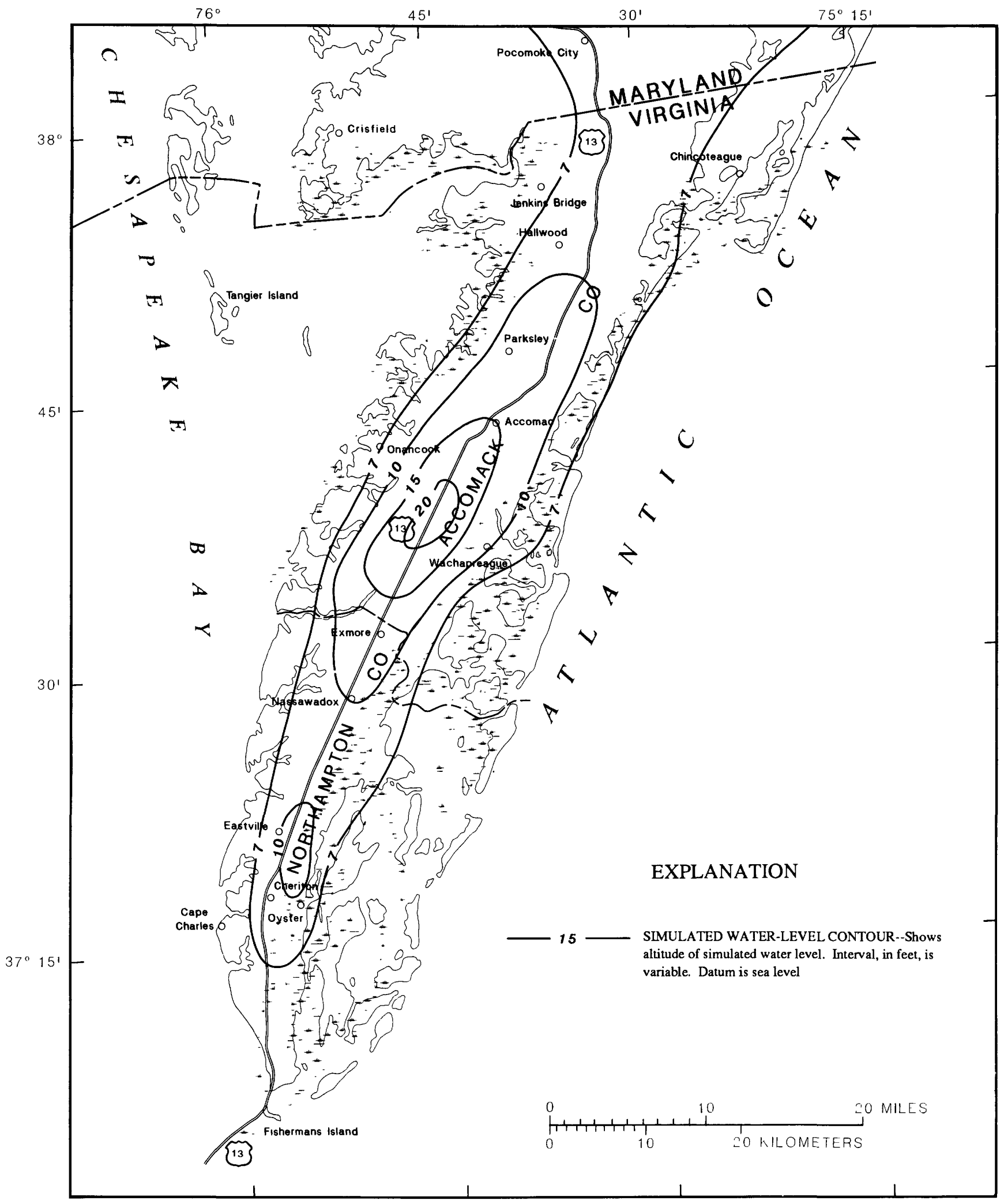

Figure 31. Simulated water levels in the middle Yorktown-Eastover aquifer for prepumping conditions. 


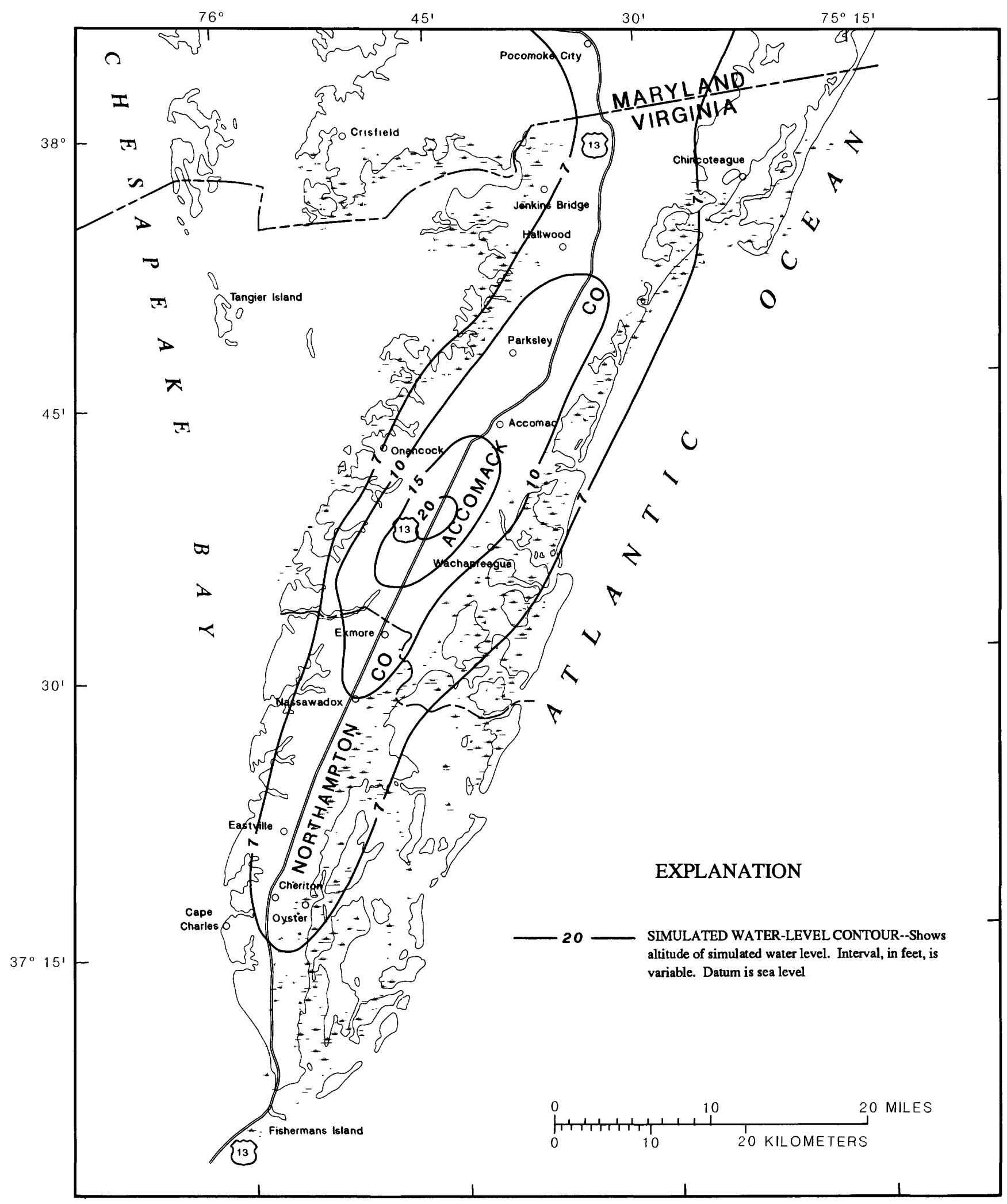

Figure 32. Simulated water levels in the lower Yorktown-Eastover aquifer for prepumping conditions. 


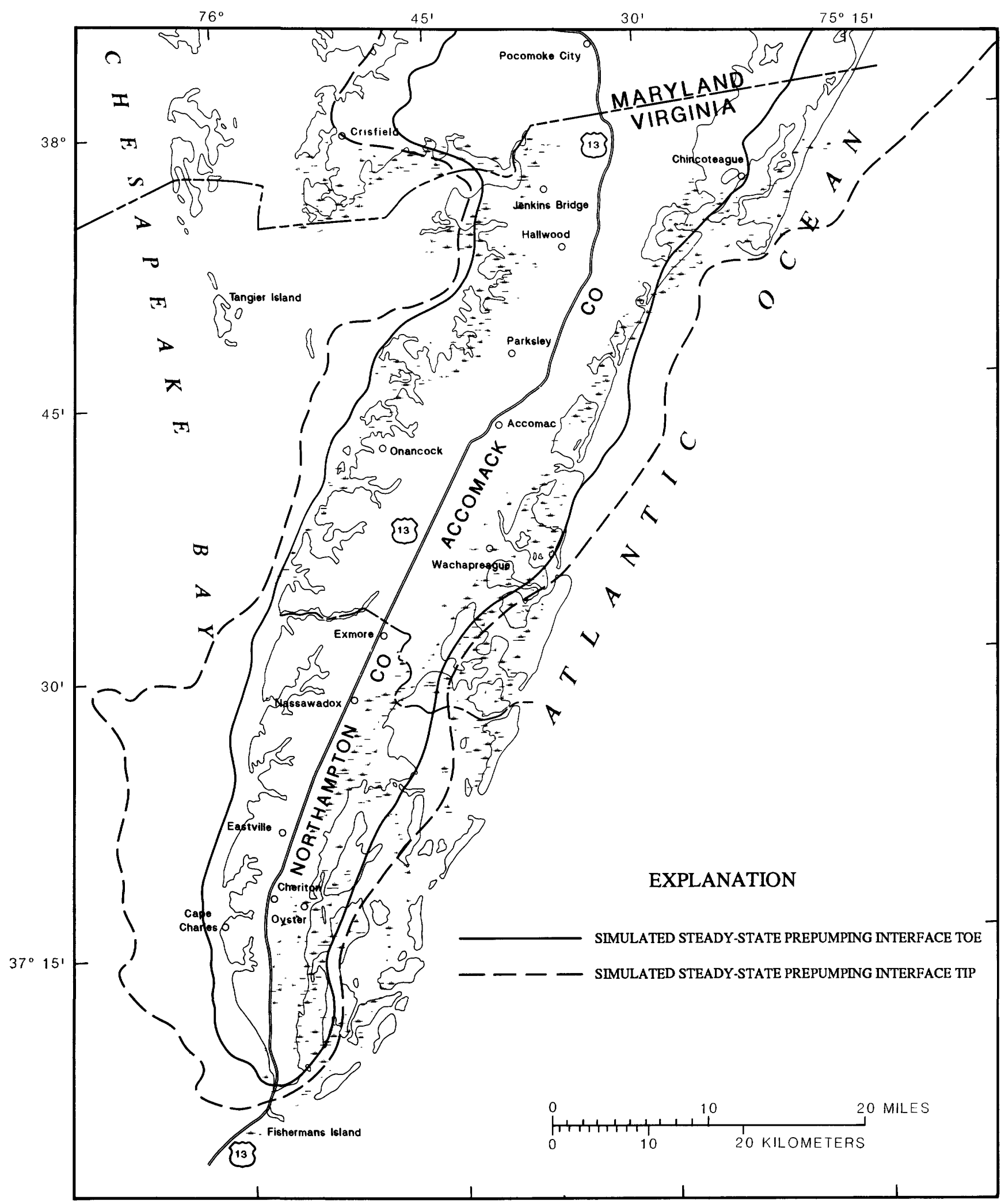

Figure 33. Simulated position of the saltwater-freshwater interface for the upper Yorktown-Eastover aquifer for prepumping conditions. 


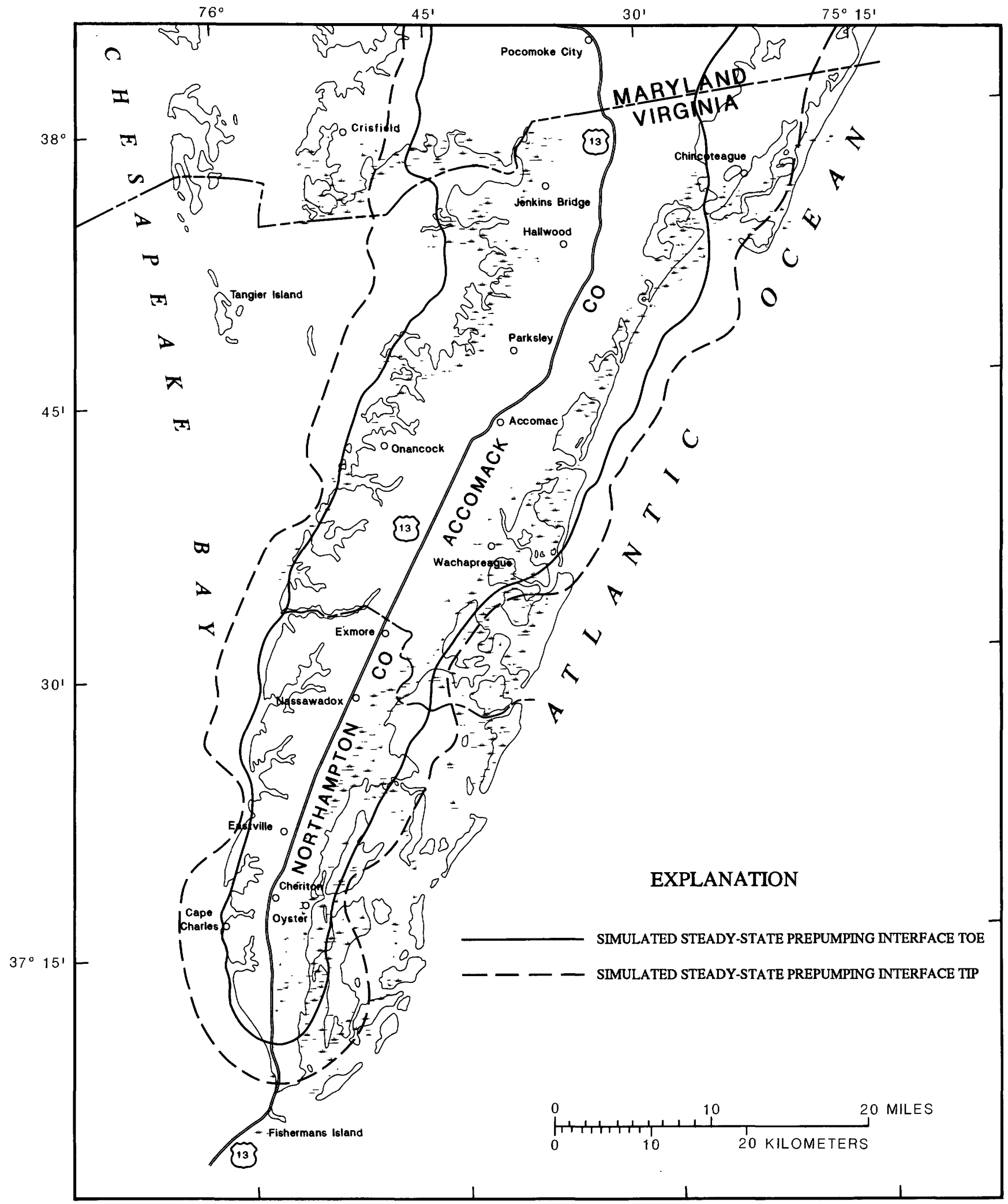

Figure 34. Simulated position of the saltwater-freshwater interface for the middle Yorktown-Eastover aquifer for prepumping conditions. 


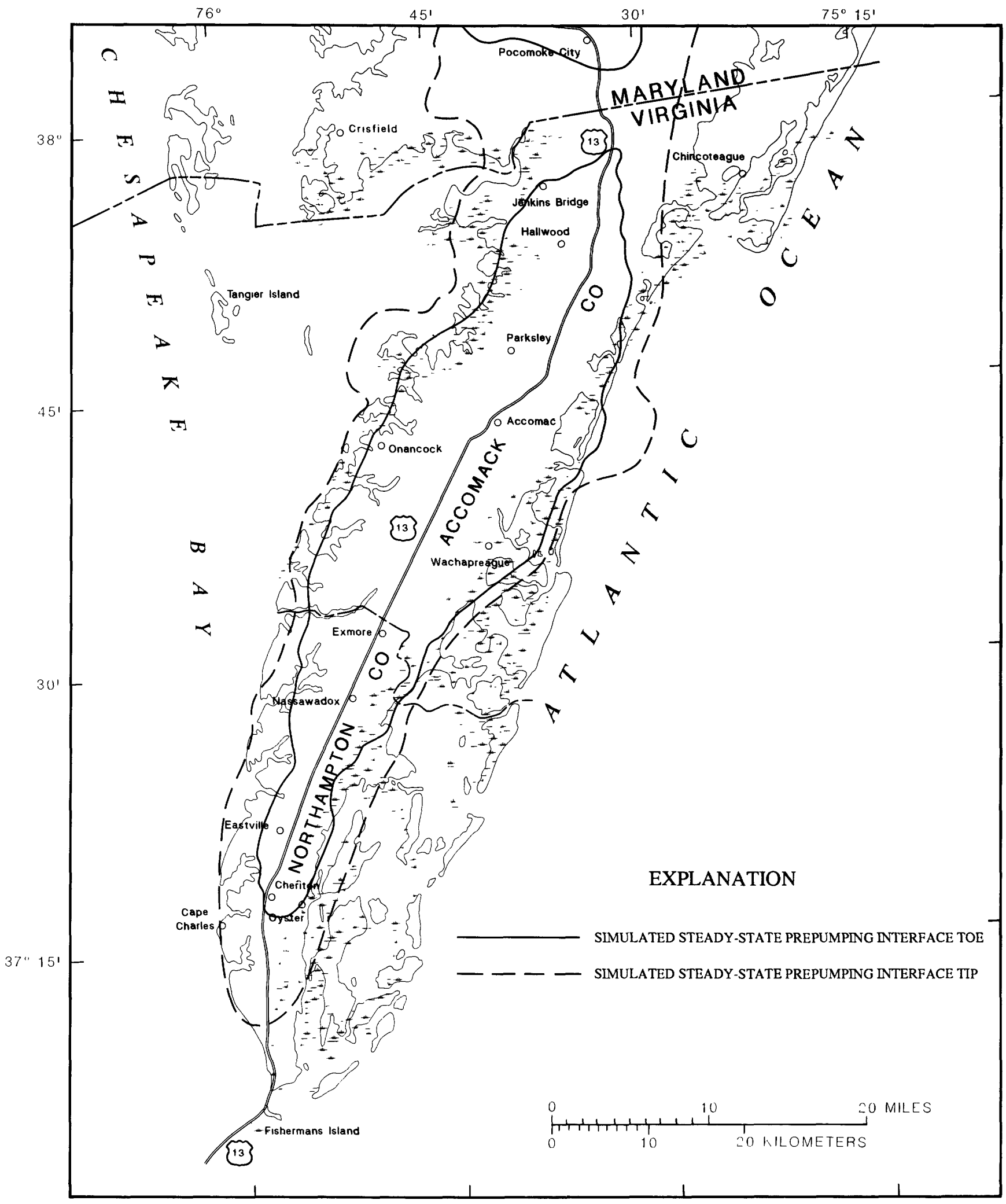

Figure 35. Simulated position of the saltwater-freshwater interface for the lower Yorktown-Eastover aquifer for prepumping conditions. 
the saltwater-freshwater interface is a useful reference for examining the relative effects of withdrawals on the ground-water-flow system.

\section{Transient-Model Simulation of Pumping Conditions}

A transient-model simulation was conducted to simulate the effects of ground-water withdrawals on the Eastern Shore from 1940 to 1988 . The water levels and interface position generated in the prepumping steady-state simulation were used as initial conditions in the transient-model analysis. Aquifer and confining-unit hydraulic characteristics were equivalent to those used when simulating prepumping conditions. The transient simulation shows the effects of historic withdrawals on the ground-waterflow system.

\section{Time Discretization and Ground-Water Withdrawals}

Pumpage has varied during the history of ground-water withdrawal on the Eastern Shore (fig. 36). The transient changes in withdrawals are accounted for in the model by dividing historical pumpage into 12 pumping periods. Model-simulated pumping periods are the years 1940-44, 1945-46, 1947-55, 1956-64, 1965-67, 1968-72, 1973-77, $1978-79,1980-81,1982-84,1985-86$, and 1987-88. Each pumping period starts on January 1 of its beginning year and ends on December 31 of its final year. Simulated withdrawals were calculated by aquifer for each pumping period from annual withdrawal data (fig. 18) using an average for the time period (fig. 36, table 15). Aquifer-top maps (figs. 3-9) and well-screen depth information were used to assign the withdrawals to the appropriate aquifer. Withdrawals for multiaquifer wells were determined by the percentage of the total screen present in each aquifer.

\section{Results of Simulation}

The transient simulation was evaluated by comparing simulated water levels to measured water levels. This comparison was made for a network of 48 observation wells distributed throughout the model area. Water levels for 12 of the observation wells are presented in figures 37-39. The observation wells selected are distributed throughout the model area, and water-level changes are representa- tive of the total group of observation wells. Simulated water levels show reasonable agreement with measured water levels in all of the observation wells for the period of record. Some simulated water levels are slightly higher than measured water levels and some are slightly lower.

Simulated water levels for 1988 are shown in figures 40-42. Measured water levels are included on these maps to allow comparison between simulated and measured values. A comparison of simulated 1988 water levels with prepumping water levels (figs. 30-32) indicates a decline in water levels around the major pumping centers. The maximum simulated water-level declines in all three aquifers occur near the town of Accomac. Maximum waterlevel declines are 18,30, and $53 \mathrm{ft}$ in the upper, middle, and lower Yorktown-Eastover aquifers, respectively. Drawdown cones associated with the major pumping centers indicate a change in groundwater flow from prepumping conditions. Prior to ground-water withdrawals, flow was from the topographic highs in the center of the peninsula toward the Chesapeake Bay and Atlantic Ocean (figs. 30-32). By 1988, simulated water-level gradients show that water is diverted toward the major pumping centers (figs. 40-42). Top-of-aquifer maps can be compared with the simulated water levels to identify areas in which the water levels are approaching the top of the aquifer. Water levels that decline below the top of a confined aquifer cause unconfined conditions in the aquifer and can result in dewatering and associated irreversible changes in the aquifer. Dewatering can contribute to compaction of aquifer sediment and eventual decreases in aquifer yields. Simulated 1988 water levels are above the tops of the aquifers throughout the model area.

The amount of ground-water flow through the system also is changed as a result of withdrawals. The majority of the water for the increase in withdrawals comes from an increase in the amount of water recharging the confined-aquifer system from the unconfined aquifer and a decrease in the amount of discharge to the unconfined aquifer. In areas where pumpage causes water levels to decline in the confined aquifers, the head difference between the unconfined-aquifer and the confined-aquifer system increases. The increased head difference causes an increase in vertical leakage through the confining unit, and some freshwater that was previously discharging from the unconfined aquifer to 


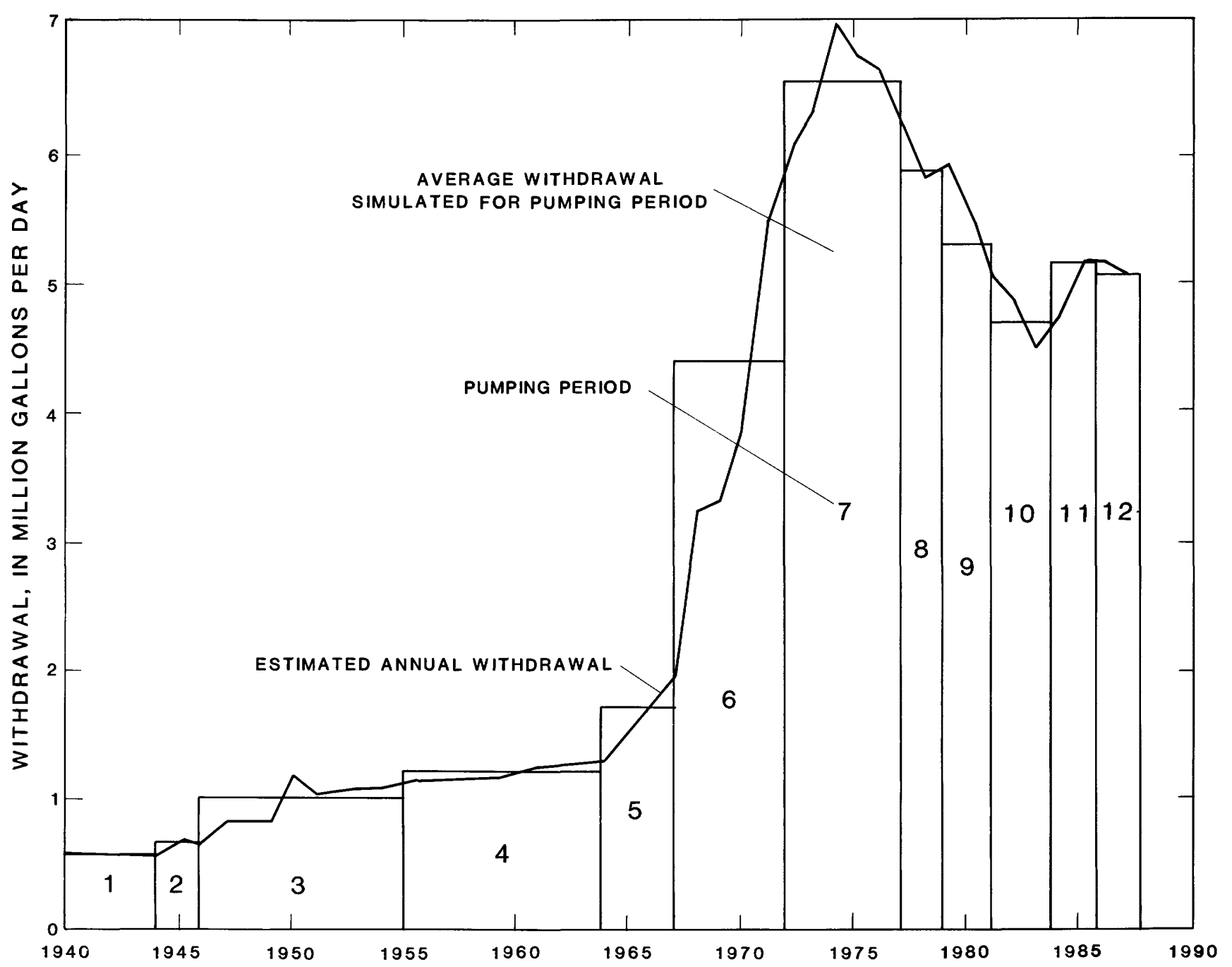

Figure 36. Estimated annual withdrawal and average withdrawal for simulated pumping periods.

surface-water bodies is diverted and flows into the confined-aquifer system. Any increase in withdrawals from the freshwater aquifers on the Eastern Shore results in a reduction in offshore freshwater discharge. A reduction in freshwater discharge affects the long-term position of the saltwaterfreshwater interface in the aquifers and could cause increased salinity in sensitive estuarine environments. The steady-state prepumping simulation indicates that $11.07 \mathrm{Mgal} / \mathrm{d}$ recharges and discharges the confined ground-water-flow system (table 16).

When 1988 withdrawals are simulated, the recharge to the confined aquifers increases to $13.11 \mathrm{Mgal} / \mathrm{d}$, and natural discharge decreases to $8.64 \mathrm{Mgal} / \mathrm{d}$.

The transient simulation of conditions for the period 1940-88 shows no movement of the saltwater-freshwater interface, although significant changes in the flow system occur. The simulated position of the saltwater-freshwater interface for 1988 conditions is identical to the simulated interface position for prepumping conditions (figs. 33-35). This result indicates that interface response is slow and takes place over long periods of time. Similar findings have been recorded in other saltwater-intrusion studies (Bond and Bredehoeft, 1987; Essaid, 1990b; Meisler and others, 1985). The investigation by Bond and Bredehoeft (1987) using a two-dimensional solute-transport model showed the main pathway for saltwater intrusion over short timeframes was downward vertical leakage of saltwater from surface-water bodies into the shallow aquifers. Simulated water-level gradients for 


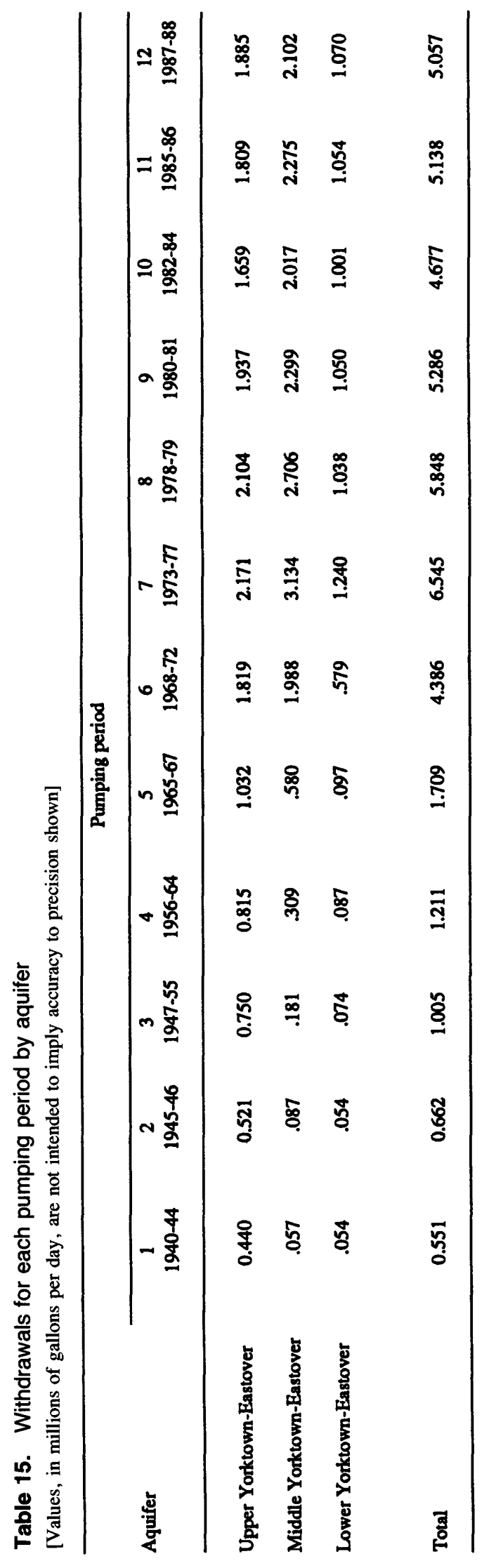



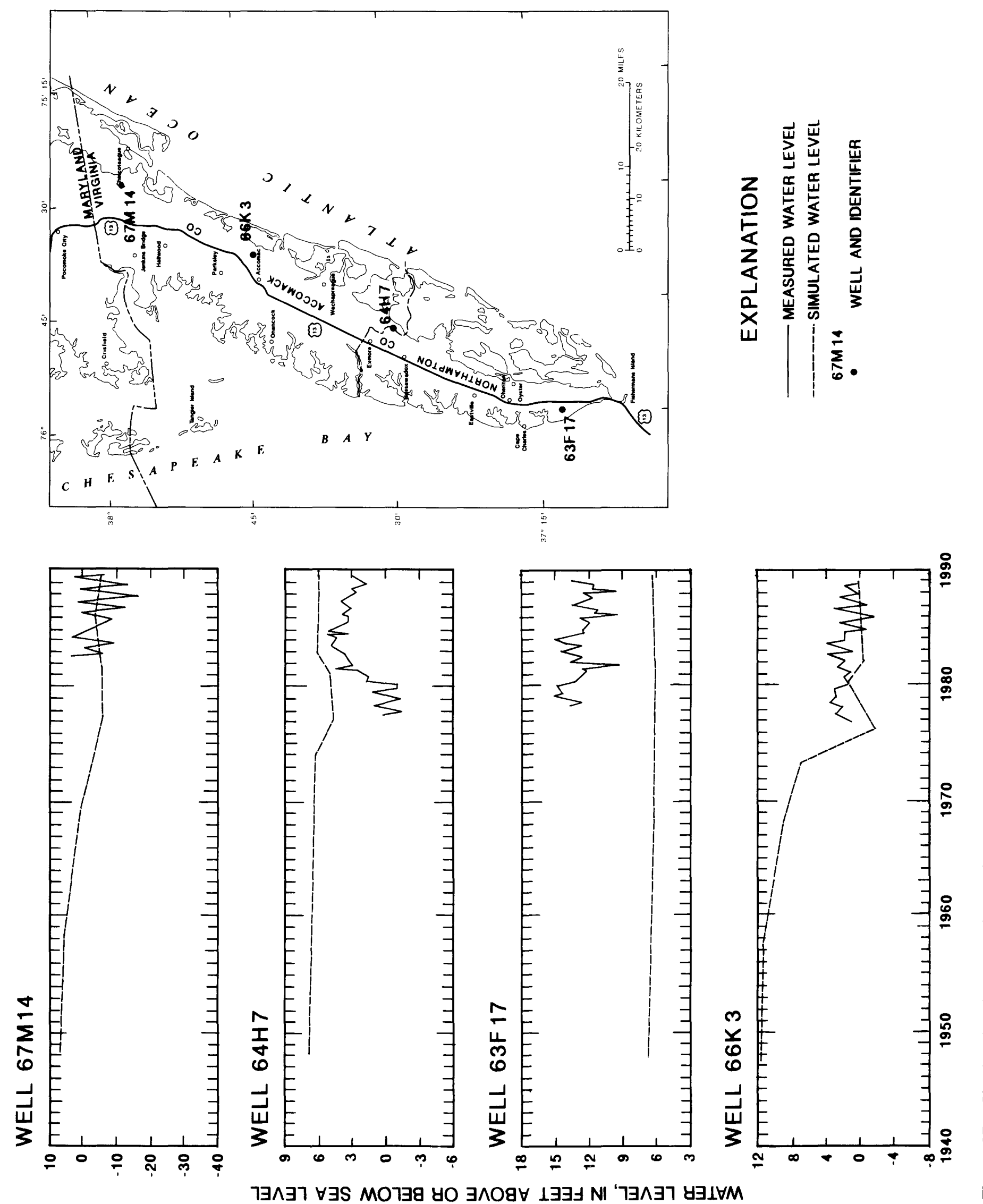

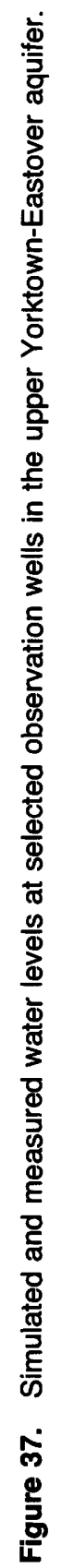



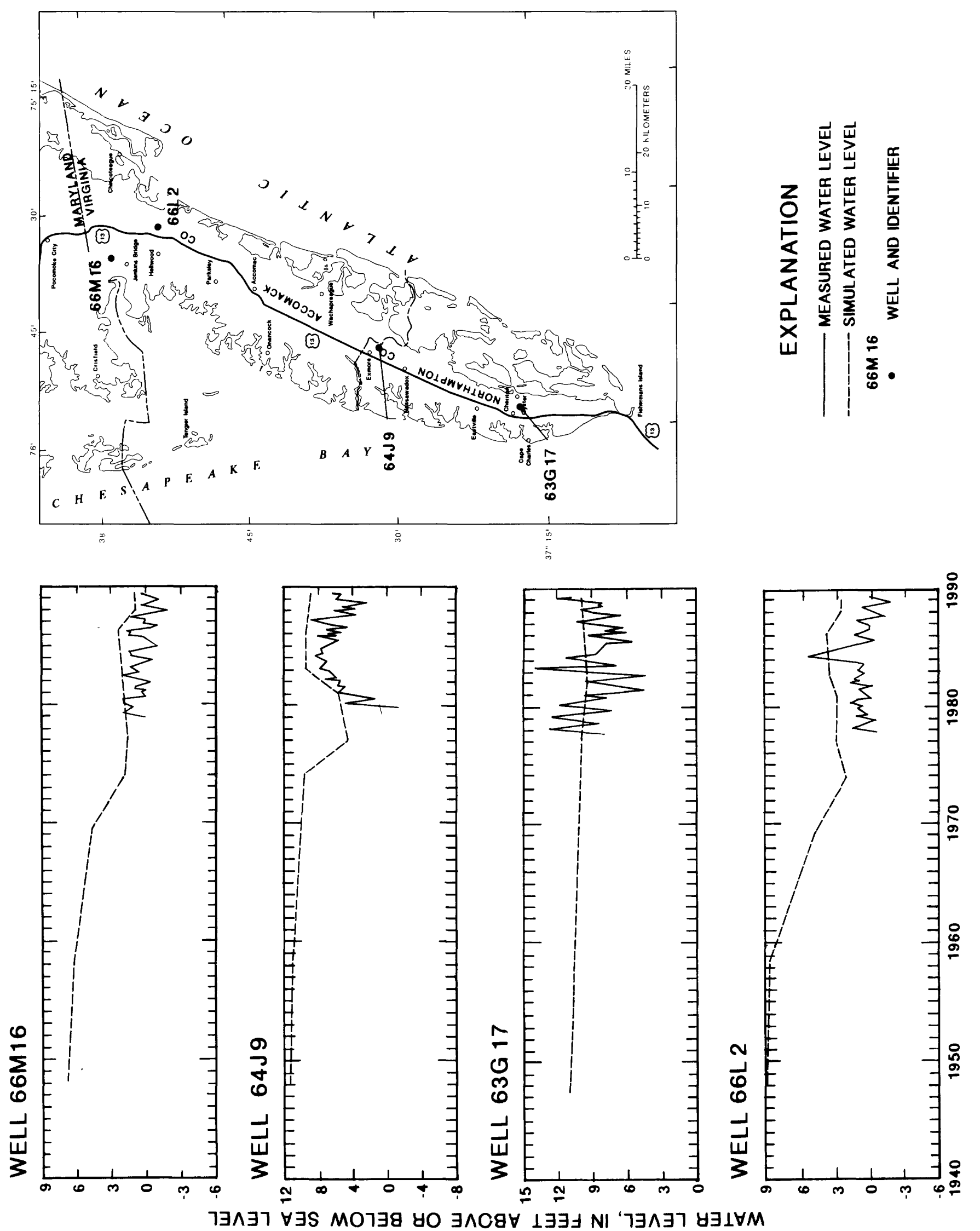

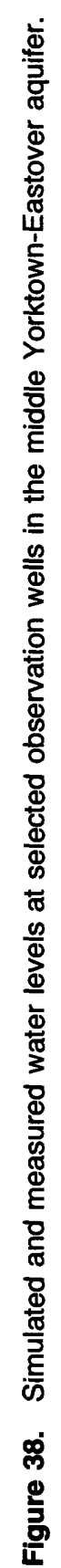



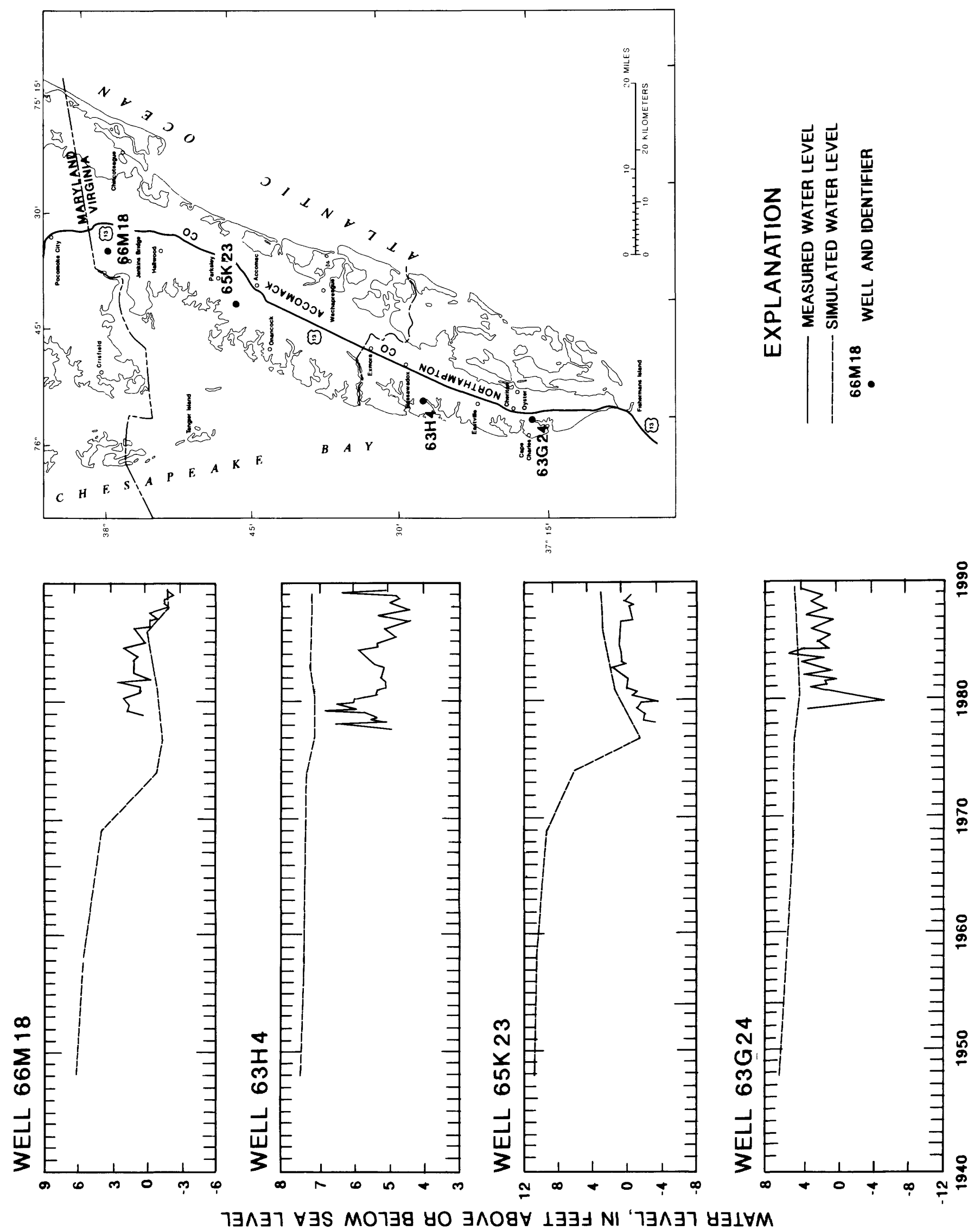

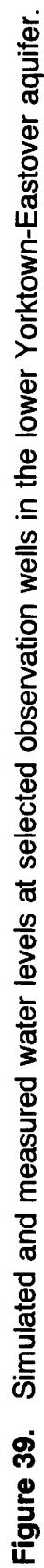




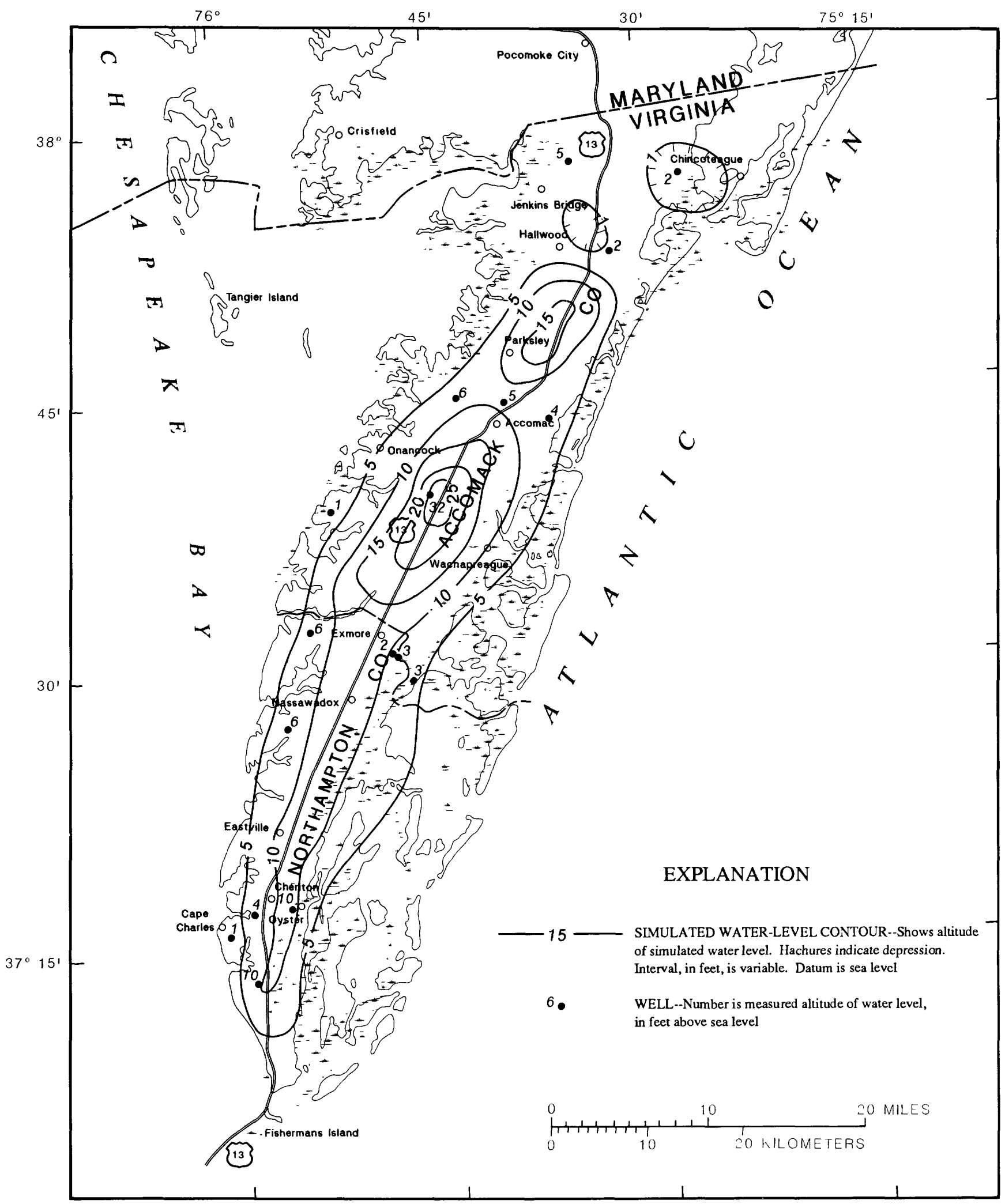

Figure 40. Simulated and measured water levels in the upper Yorktown-Eastover aquifer, 1988. 


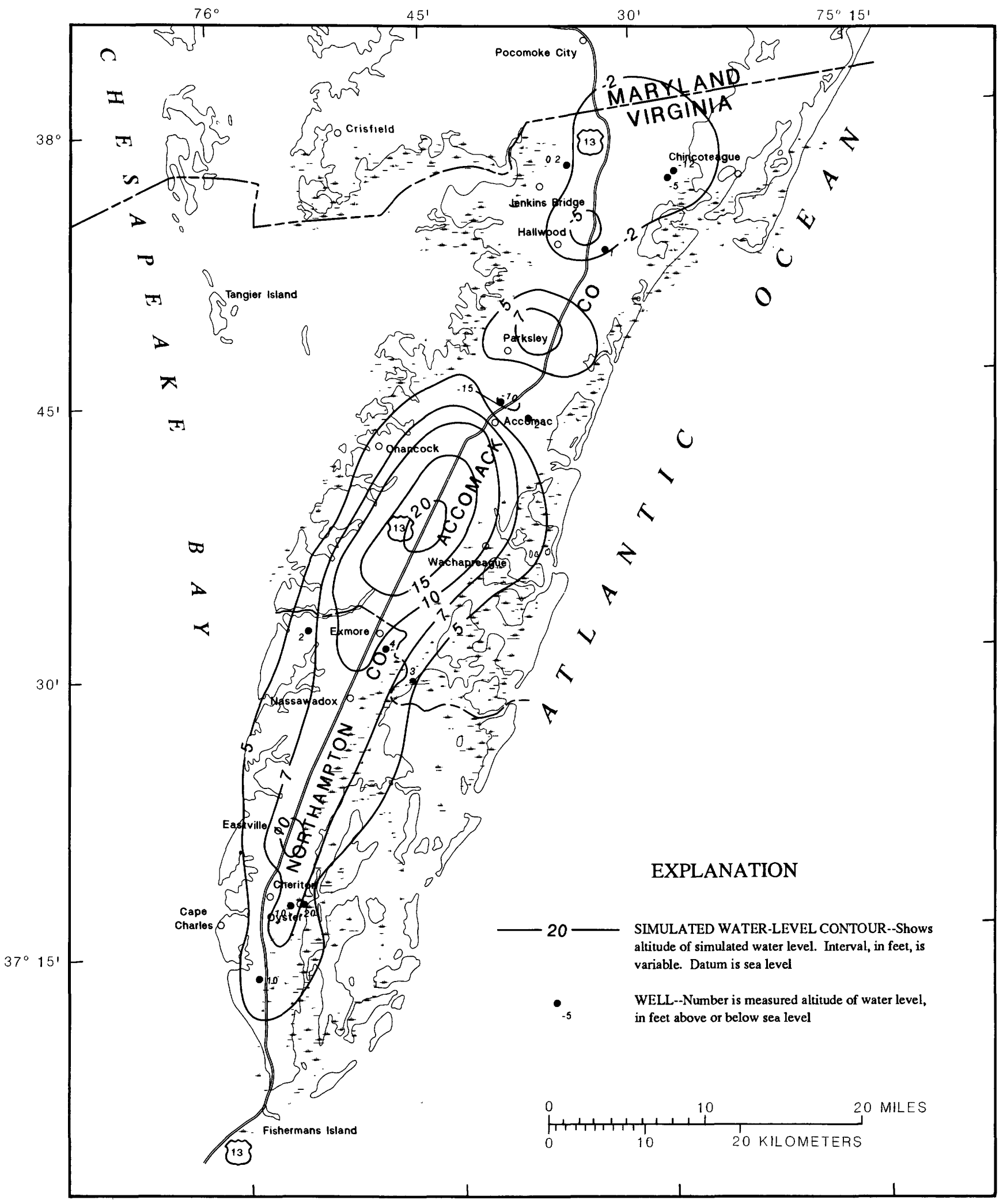

Figure 41. Simulated and measured water levels in the middle Yorktown-Eastover aquifer, 1988. 


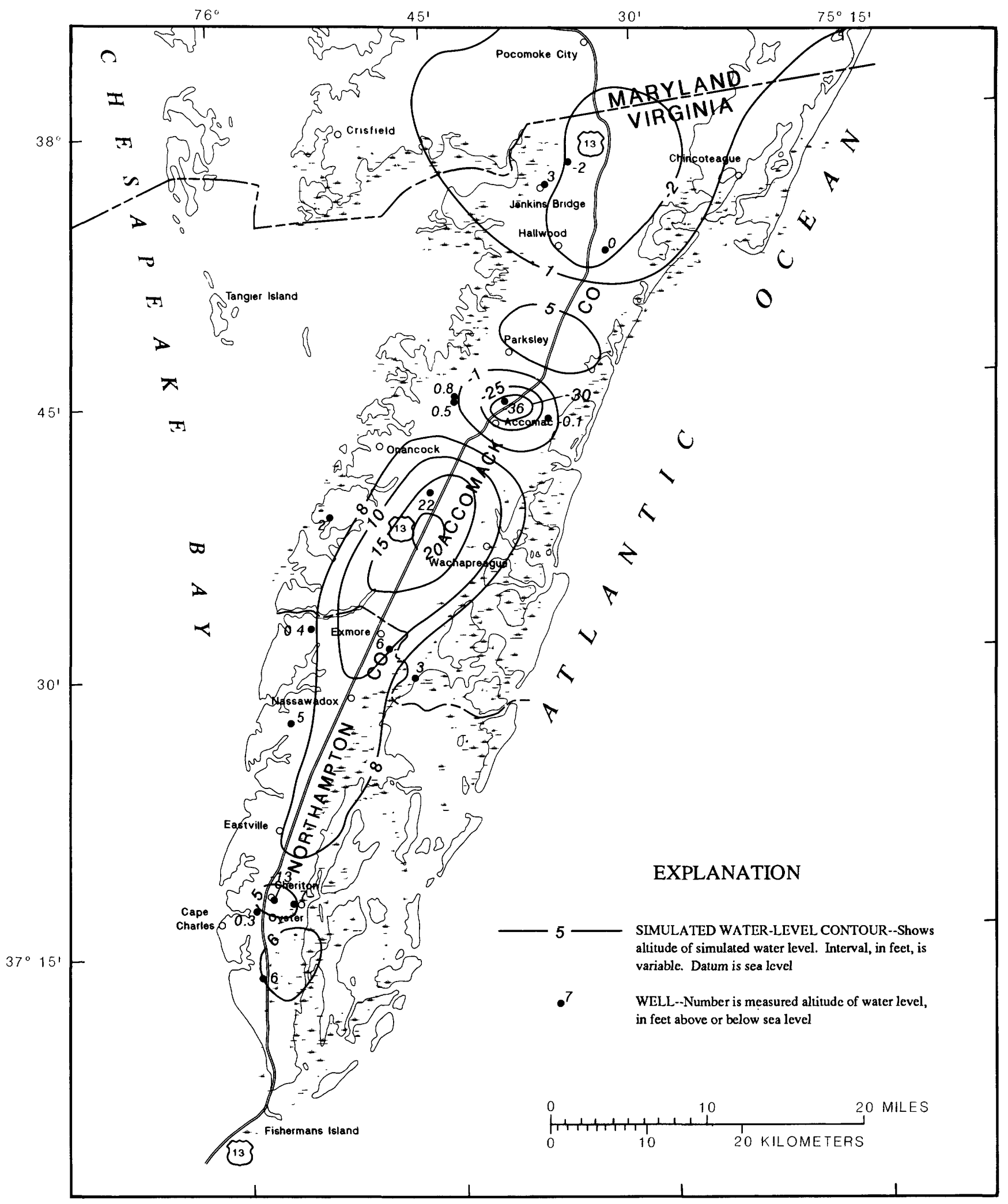

Figure 42. Simulated and measured water levels in the lower Yorktown-Eastover aquifer, 1988. 


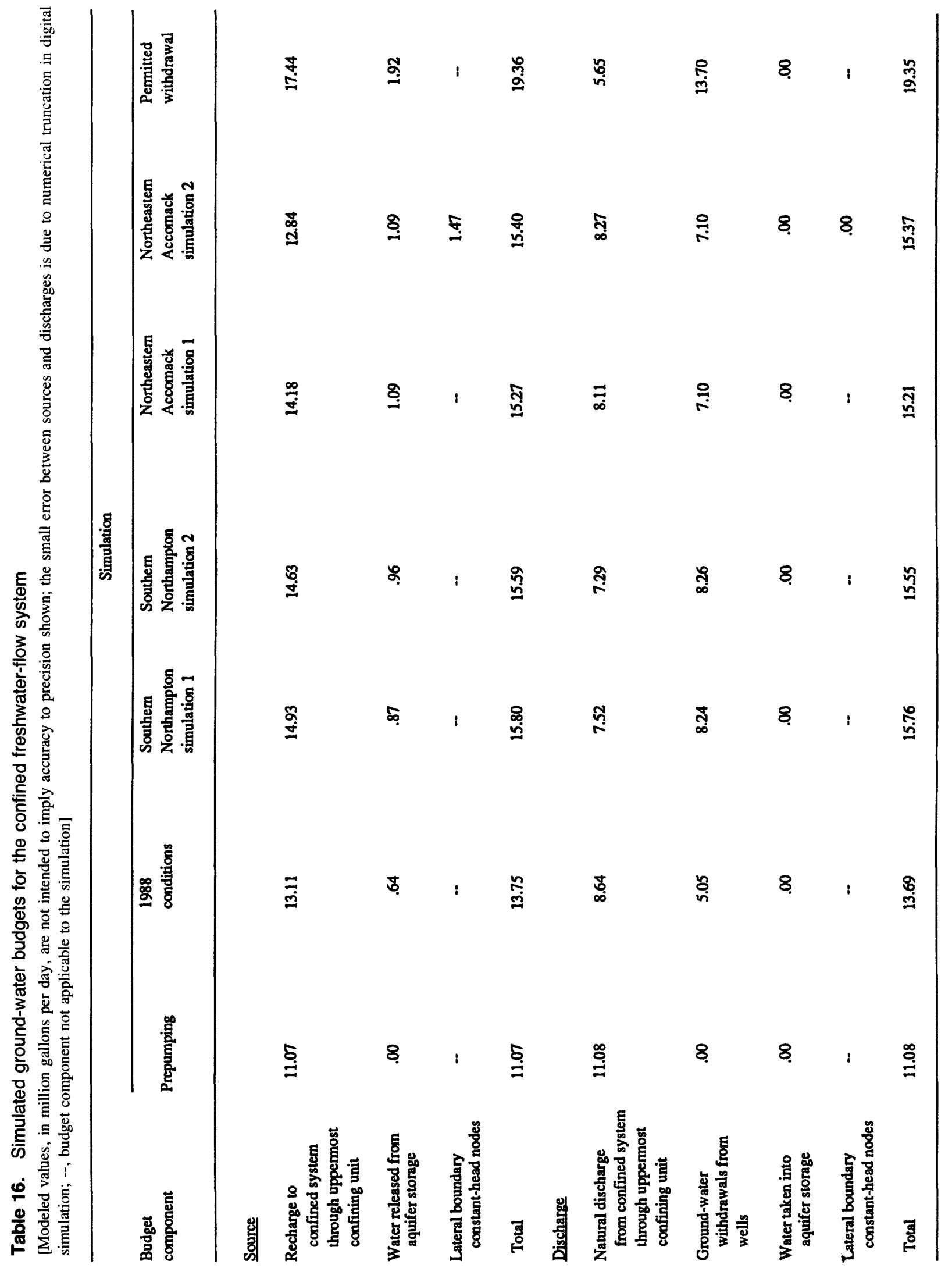


1988 conditions on the Eastern Shore show that there is no potential for downward vertical leakage of saltwater through the upper Yorktown-Eastover confining unit above the freshwater part of the upper Yorktown-Eastover aquifer.

The slow movement of the saltwaterfreshwater interface was investigated using a transient simulation that continued 1988 withdrawals for 1,000 years. The model-simulated interface did not reach an equilibrium position for 1988 withdrawals by the end of the 1,000-year simulation period. The simulated position of the saltwater-freshwater interface toe for the 1,000-year run is shown along with the 1988 interface in figures $43-45$. The position of the interface toe is shown because it is the most landward extension of the saltwater-freshwater interface. The locations of greatest interface movement in each aquifer correspond to the areas of greatest pumpage. Although the transient simulation from 1940 to 1988 shows no movement of the interface toe from the prepumping steady-state simulation, continuing 1988 withdrawals for 1,000 years causes landward movement of the interface toe along most of the coast in all three aquifers. The interface toe at the southern end of Northampton County in the upper Yorktown-Eastover aquifer (fig. 43) moved approximately $1 \mathrm{mi}$ landward on the bay side of the peninsula and $0.5 \mathrm{mi}$ landward on the ocean side of the peninsula. The interface toe also moved landward approximately $1 \mathrm{mi}$ in the upper YorktownEastover aquifer near the town of Chincoteague. Maximum landward movement of the interface toe is approximately $1.5 \mathrm{mi}$ in the middle YorktownEastover aquifer (fig. 44), also near the town of Chincoteague. The interface toe moves landward a maximum of approximately $1 \mathrm{mi}$ in the lower Yorktown-Eastover aquifer (fig. 45) southwest of Chincoteague. The results of this simulation support previous findings that movement of the saltwaterfreshwater interface is slow and takes place over long periods of time. It is important to remember, however, that a sharp-interface model provides no information on the rate of movement of dilute saltwater in the transition zone.

\section{Application of Ground-Water-Flow Model}

The prepumping, steady-state-model analysis and the historical transient-model analysis indicate that the model conceptualization is a reasonable representation of the ground-water-flow system of the
Eastern Shore. Three scenarios of hypothetical increases in ground-water withdrawals were developed in cooperation with Accomack County, Northampton County, and the VWCB. The results of the simulations of the scenarios are examined to increase our understanding of the response of the ground-water-flow system to additional stress. The simulations are not intended to predict exact groundwater conditions in the future; however, the results provide information that could be useful in evaluating the ground-water resource and its ability to meet future water needs.

\section{Southern Northampton County Scenario}

The southern part of Northampton County is experiencing rapid growth. Protection of the groundwater resource in this area is of concern because most of the expected development is in coastal areas that could be susceptible to saltwater intrusion. In this scenario, withdrawals are increased in the southern part of Northampton County, and currently permitted users as well as potential projected users are included. The scenario consists of two separate model simulations that illustrate the effects of increased withdrawals with two different well distributions. In simulation 1 , withdrawals are increased to permitted levels at existing well locations, and additional withdrawal wells are placed in the vicinity of expected growth areas (fig. 46). In simulation 2 , withdrawals are increased by the same amount but are distributed evenly throughout hypothetical well fields in the center of the peninsula.

\section{Simulation 1}

Results from the transient simulation of 1988 conditions were used as initial conditions for a 50-year transient simulation to examine the effects of increased withdrawals in the southern part of Northampton County. A summary of locations and rates of hypothetical withdrawals and aquifers penetrated for the southern part of Northampton County in simulation 1 is presented in table 17 . Total withdrawal for the area is $3.761 \mathrm{Mgal} / \mathrm{d}$, which represents an increase of $3.213 \mathrm{Mgal} / \mathrm{d}$ over 1988 withdrawal. Withdrawals from existing wells in the southern part of the peninsula are increased to their permitted levels. Additional withdrawal wells were located by the VWCB according to preliminary or expected permit applications (fig. 46). Approximately 57,29 , and 14 percent of the additional 


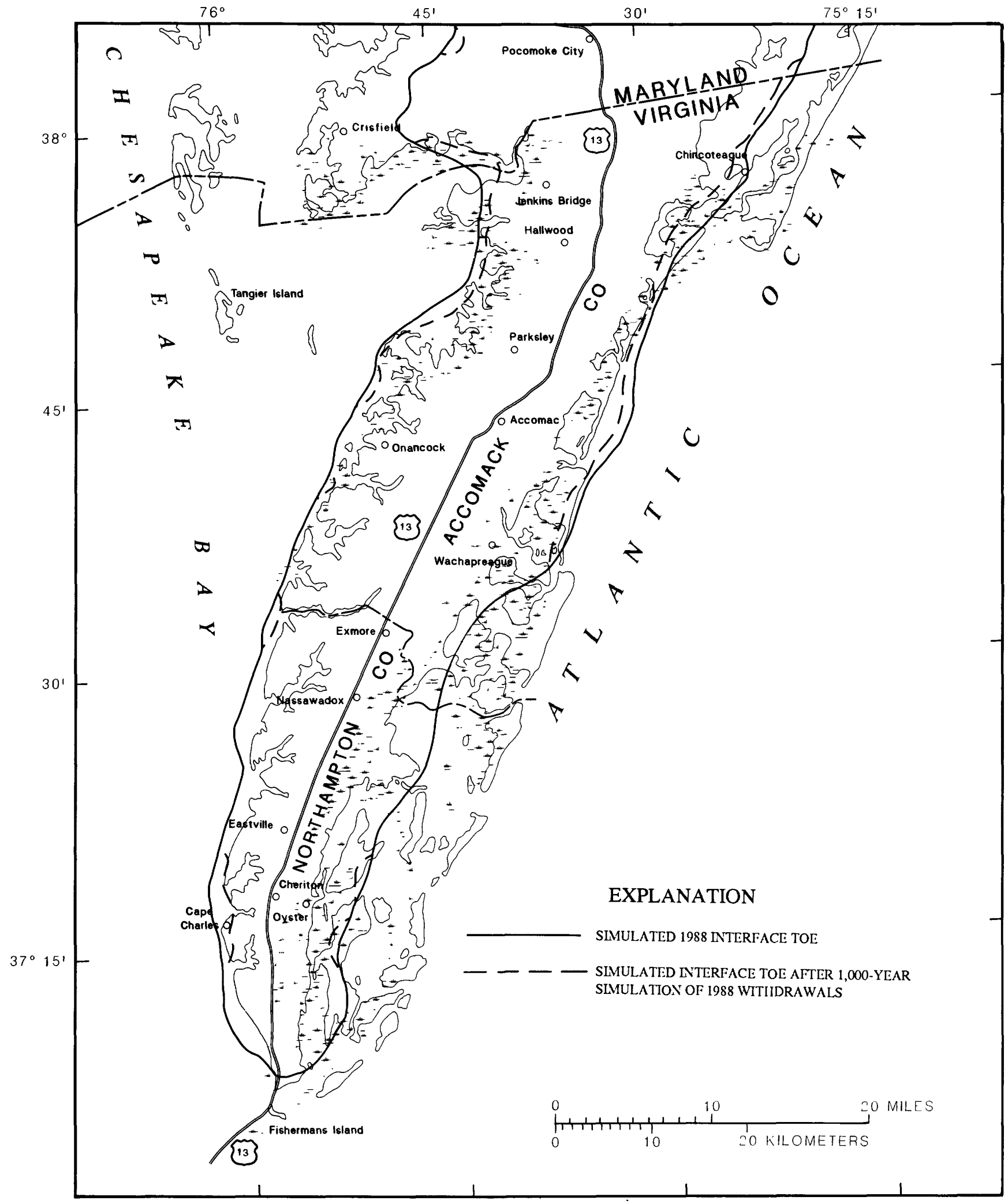

Figure 43. Simulated position of the saltwater-freshwater interface toe for a 1,000-year transient run using 1988 withdrawals in the upper Yorktown-Eastover aquifer. 


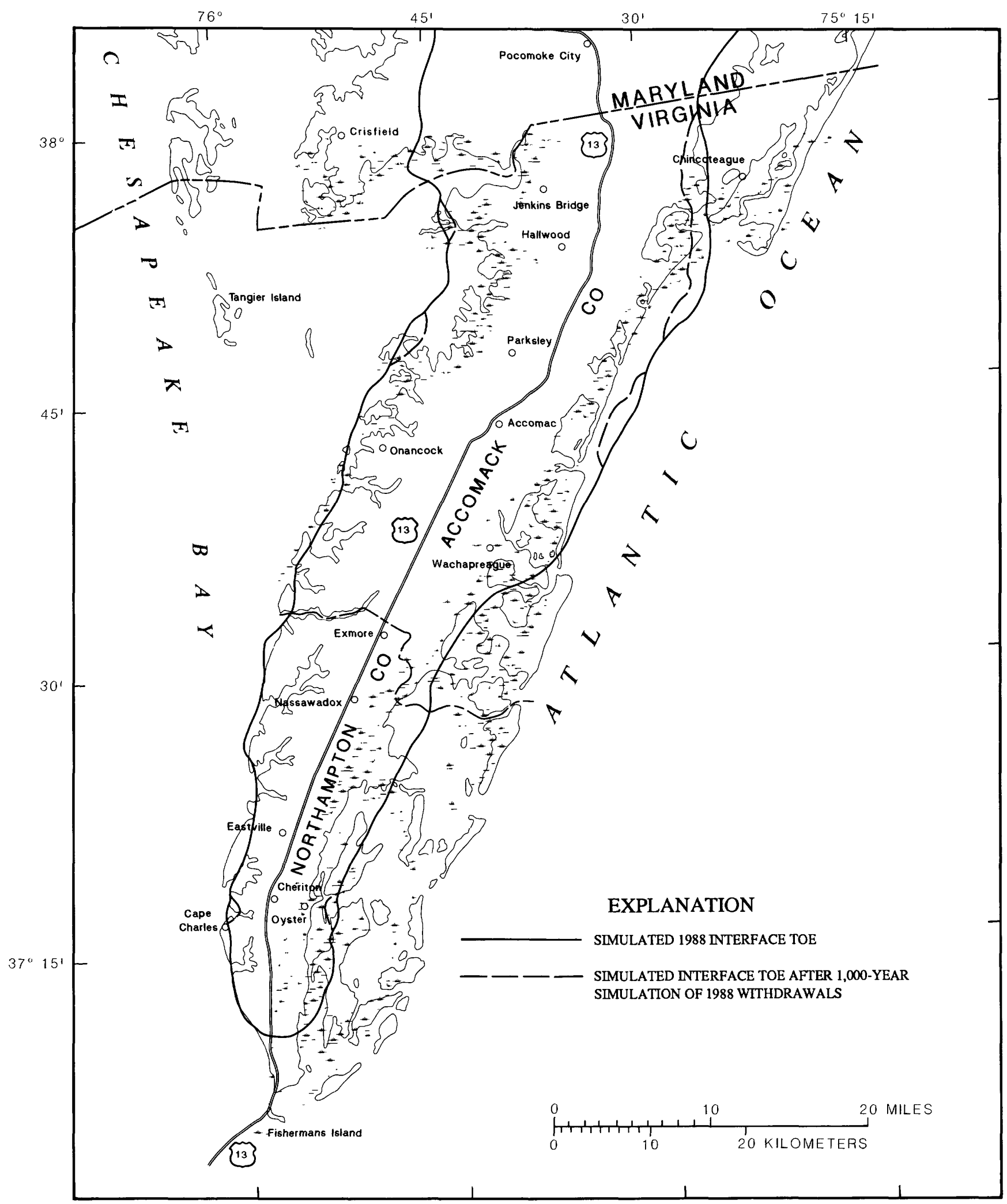

Figure 44. Simulated position of the saltwater-freshwater interface toe for a 1,000-year transient run using 1988 withdrawals in the middle Yorktown-Eastover aquifer. 


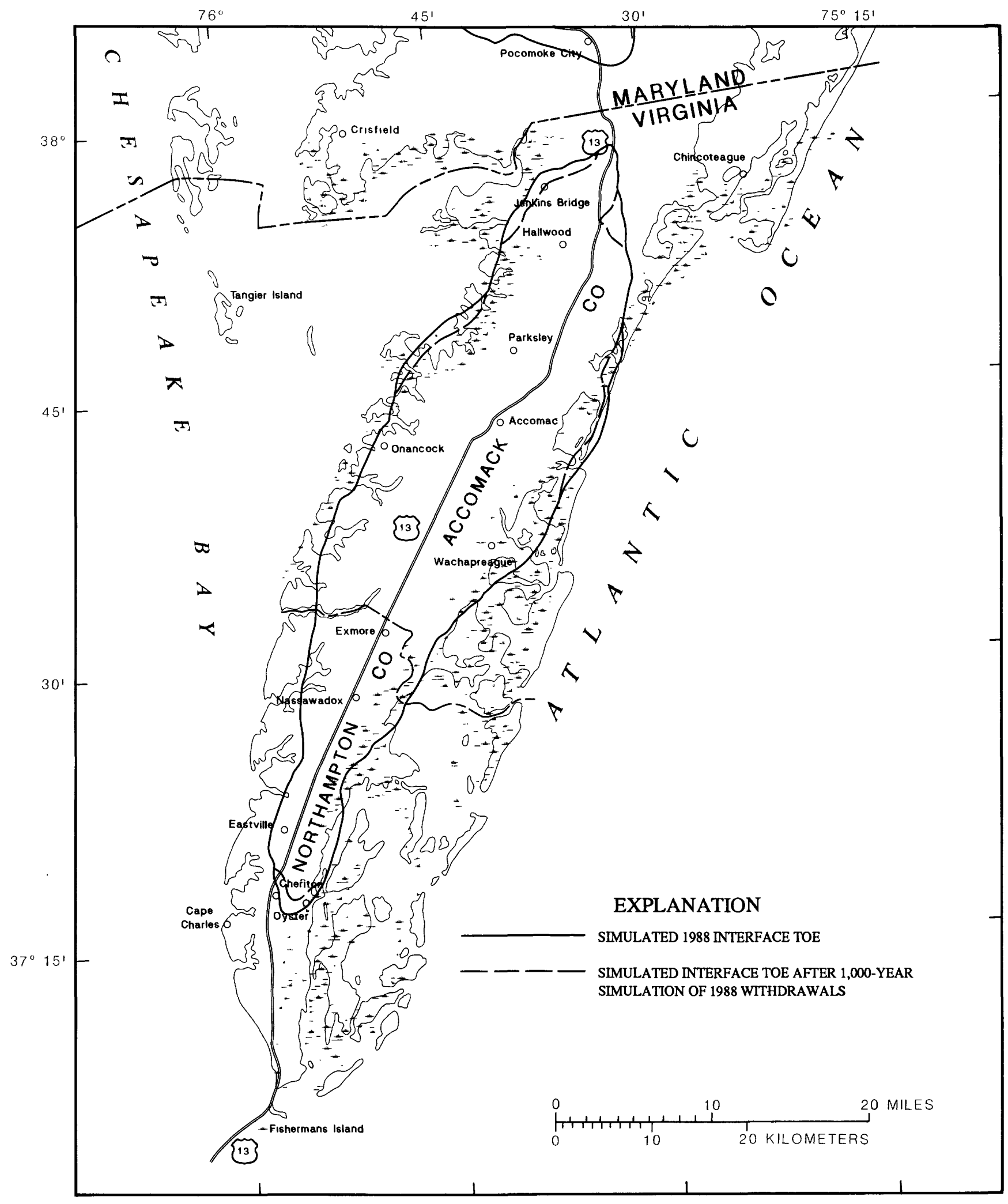

Figure 45. Simulated position of the saltwater-freshwater interface toe for a 1,000-year transient run using 1988 withdrawals in the lower Yorktown-Eastover aquifer. 


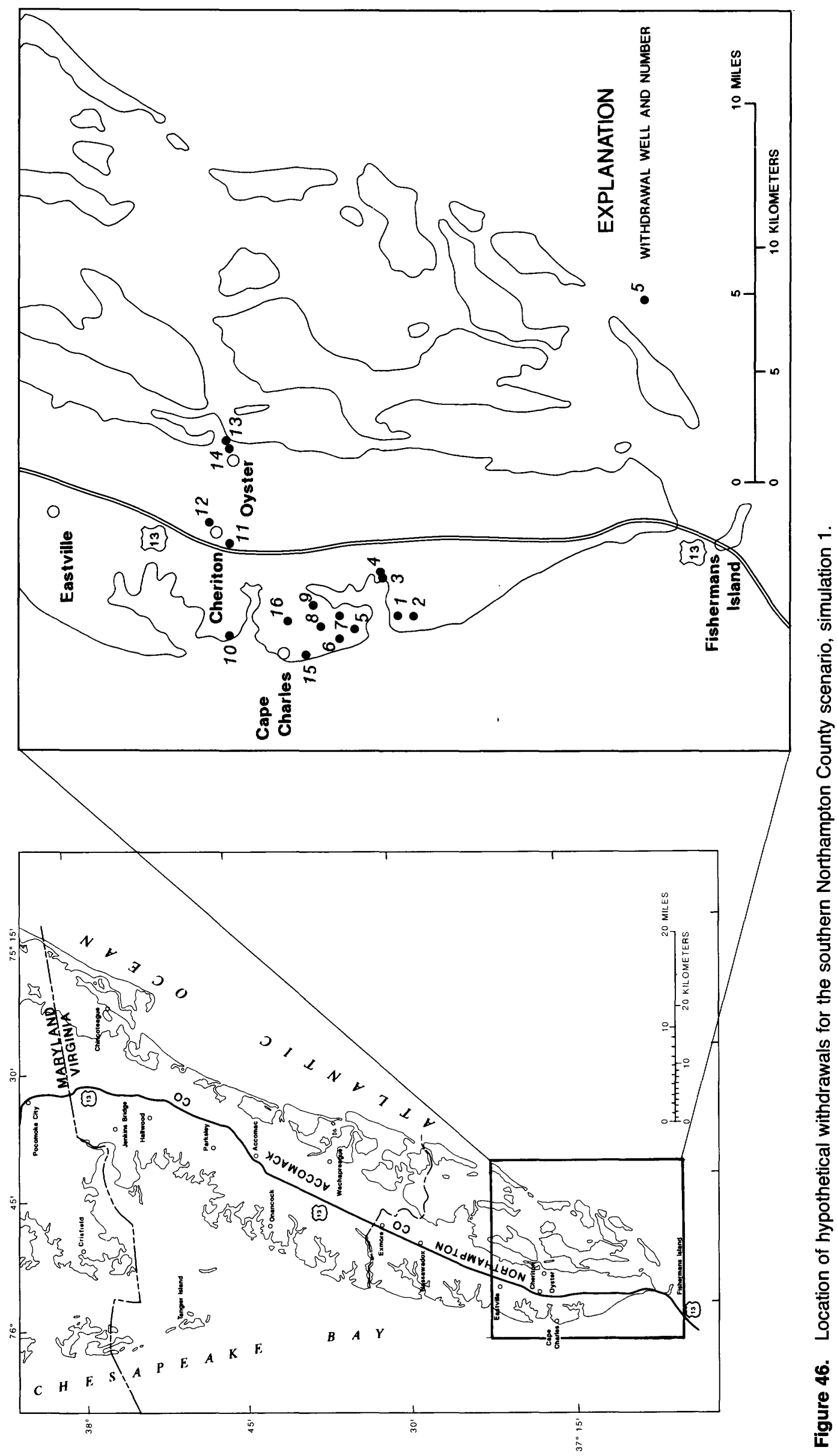


Table 17. Withdrawals for southern Northampton County scenario, simulation 1

[Mgal/d, million gallons per day; latitude and longitude are reported in degrees, arc minutes, arc seconds]

\begin{tabular}{lllll}
\hline $\begin{array}{l}\text { Map } \\
\text { number }\end{array}$ & Latitude & Longitude & $\begin{array}{l}\text { Withdrawal } \\
\text { (Mgal/d) }\end{array}$ & Aquifer penetrated \\
\hline 1 & 371336 & 0760019 & 0.047 & Upper Yorktown-Eastover \\
2 & 371314 & 0760021 & .047 & Upper Yorktown-Eastover \\
3 & 371353 & 0755923 & .093 & Upper Yorktown-Eastover \\
4 & 371354 & 0755908 & .093 & Upper Yorktown-Eastover \\
5 & 371435 & 0760034 & .200 & Upper Yorktown-Eastover \\
6 & 371456 & 0760052 & .200 & Upper Yorktown-Eastover \\
7 & 371455 & 0760008 & .200 & Upper Yorktown-Eastover \\
8 & 371520 & 0760031 & .200 & Upper Yorktown-Eastover \\
9 & 371528 & 0755956 & .200 & Upper Yorktown-Eastover \\
10 & 371720 & 0760051 & .004 & Upper Yorktown-Eastover \\
11 & 371720 & 0755810 & .190 & Upper Yorktown-Eastover \\
12 & 371746 & 0755728 & 1.600 & Upper, middle, and \\
& & & & lower Yorktown-Eastover \\
13 & 371715 & 0755512 & .150 & Middle Yorktown-Eastover \\
14 & 371711 & 0755524 & .152 & Middle Yorktown-Eastover \\
15 & 371540 & 0760121 & .125 & Upper and middle Yorktown-Eastover \\
16 & 371605 & 0760019 & .260 & Upper and middle Yorktown-Eastover \\
\hline
\end{tabular}

${ }^{1}$ Locations shown on figure 46.

pumpage comes from the upper, middle, and lower Yorktown-Eastover aquifers, respectively. Pumpage for the rest of the model area is held constant at the average pumping rate for the final pumping period (pumping period 12) in the historic transient simulation. Total withdrawals for the entire model area for simulation 1 are greatest in the upper YorktownEastover aquifer and least in the lower YorktownEastover aquifer (table 18).

The hypothetical increased pumpage in the southern part of Northampton County results in water-level declines of greater than $15 \mathrm{ft}$ in each of the confined freshwater aquifers (figs. 47-49). The maximum water-level decline for the upper

Yorktown-Eastover aquifer is $16.2 \mathrm{ft}$ near the town of Cape Charles. Maximum water-level declines of 38.8 and $48.7 \mathrm{ft}$ occur east of the town of Cheriton for the middle and lower Yorktown-Eastover aquifers, respectively (table 19). The predicted declines are in addition to declines caused by ground-water withdrawals in 1988. Simulated water levels throughout the model area remain above the tops of the aquifers, indicating that dewatering would not occur at this rate and distribution of withdrawal.

The majority of the water for the increased ground-water withdrawal is provided by an increase in the amount of recharge entering the confined system and a decrease in the amount of discharge leaving the confined system (table 16). The simulated water budget presented in table 16 is for the confined freshwater-flow system; the withdrawal amounts are slightly less than the total ground-water withdrawals for the simulations (table 18) because a small part of the withdrawals are from the saltwaterflow system. The increase in freshwater withdrawal of $3.19 \mathrm{Mgal} / \mathrm{d}$ in the southern part of Northampton County causes a $1.82 \mathrm{Mgal} / \mathrm{d}$ increase in the amount of recharge to the confined aquifer system over 1988 conditions. The amount of natural discharge from the confined aquifers is reduced by 1.12 $\mathrm{Mgal} / \mathrm{d}$ from 1988 conditions.

The 50-year simulation of increased pumpage in southern Northampton County results in slight landward movement of the simulated saltwaterfreshwater interface on the Chesapeake Bay side of the peninsula off Cape Charles (figs. 47-49). The interface toe in the upper Yorktown-Eastover aquifer moves inland from the 1988 interface toe position along approximately $12 \mathrm{mi}$ of the western coastline in southern Northampton County (fig. 47); maximum landward movement is approximately $1 \mathrm{mi}$. The simulated position of the interface toe in the middle Yorktown-Eastover aquifer does not change in response to the hypothetical increase in withdrawals. Slight landward movement of the saltwaterfreshwater interface toe occurs in the lower Yorktown-Eastover aquifer (fig. 49). The simulated 1988 interface toe position is onshore at this loca- 
Table 18. Withdrawal by aquifer for model scenarios

[Values in millions of gallons per day]

\begin{tabular}{llllll}
\hline & & & \multicolumn{3}{c}{ Scenario } \\
\cline { 2 - 6 } Aquifer & $\begin{array}{l}\text { Pumping } \\
\text { period 12 } \\
(1987-88)\end{array}$ & $\begin{array}{l}\text { Southem } \\
\text { Northampton } \\
\text { simulation 1 }\end{array}$ & $\begin{array}{l}\text { Southem } \\
\text { Northampton } \\
\text { simulation 2 }\end{array}$ & $\begin{array}{l}\text { Northeastem } \\
\text { Accomack } \\
\text { simulations 1\&2 }\end{array}$ & $\begin{array}{l}\text { Permitted } \\
\text { withdrawal }\end{array}$ \\
\hline $\begin{array}{l}\text { Upper Yorktown-Eastover } \\
\text { Middle Yorktown-Eastover }\end{array}$ & 1.888 & 3.801 & 2.951 & 2.531 & 4.446 \\
Lower Yorktown-Eastover & 1.103 & 2.915 & 3.088 & 3.431 & 6.959 \\
Total & 1.070 & 1.558 & 2.235 & 1.201 & 2.419 \\
\hline
\end{tabular}

Table 19. Maximum water-level decline from 1988 flow conditions for model scenarios

\begin{tabular}{|c|c|c|c|c|}
\hline Aquifer & $\begin{array}{l}\text { Decline } \\
\text { (feet) }\end{array}$ & $\begin{array}{l}\text { Grid } \\
\text { row }\end{array}$ & $\begin{array}{l}\text { Grid } \\
\text { column }\end{array}$ & $\begin{array}{l}\text { Approximate } \\
\text { areal location }\end{array}$ \\
\hline \multicolumn{5}{|c|}{ Southem Northampton County simulation 1} \\
\hline Upper Yorktown-Eastover & 16.2 & 85 & 24 & Town of Cape Charles \\
\hline Middle Yorktown-Eastover & 38.8 & 80 & 29 & East of Cheriton \\
\hline Lower Yorktown-Eastover & 48.7 & 80 & 26 & Town of Cheriton \\
\hline \multicolumn{5}{|c|}{ Southem Northampton County simulation 2} \\
\hline Upper Yorktown-Eastover & 8.0 & 68 & 26 & Town of Nassawadox \\
\hline Middle Yorktown-Eastover & 22.0 & 76 & 26 & Town of Eastville \\
\hline Lower Yorktown-Eastover & 22.4 & 76 & 26 & Town of Eastville \\
\hline \multicolumn{5}{|c|}{ Northeastem Accomack County simulation 1} \\
\hline Upper Yorktown-Eastover & 17.2 & 19 & 34 & Town of Hallwood \\
\hline Middle Yorktown-Eastover & 29.7 & 19 & 34 & Town of Hallwood \\
\hline Lower Yorktown-Eastover & 26.4 & 19 & 34 & Town of Hallwood \\
\hline \multicolumn{5}{|c|}{ Northeastem Accomack County simulation 2} \\
\hline Upper Yorktown-Eastover & 15.8 & 19 & 34 & Town of Hallwood \\
\hline Middle Yorktown-Eastover & 27.9 & 19 & 34 & Town of Hallwood \\
\hline Lower Yorktown-Eastover & 24.6 & 19 & 34 & Town of Hallwood \\
\hline \multicolumn{5}{|c|}{ Permitted withdrawal } \\
\hline Upper Yorktown-Eastover & 29.1 & 56 & 28 & Town of Exmore \\
\hline Middle Yorktown-Eastover & 95.3 & 56 & 28 & Town of Exmore \\
\hline Lower Yorktown-Eastover & 68.0 & 34 & 32 & Town of Accomac \\
\hline
\end{tabular}

tion on the southern tip of the peninsula. The hypothetical increase in withdrawals causes the western boundary of the 1988 interface position to move approximately $0.5 \mathrm{mi}$ in the lower YorktownEastover aquifer.

Although saltwater intrusion due to horizontal movement of the saltwater-freshwater interface takes place over long periods of time, saltwater intrusion due to induced downward vertical leakage can occur rapidly as a result of large changes in head gradient. Simulated water levels show offshore water-level declines that cause a reversal of ground-water flow from 1988 conditions (fig. 47). Simulated waterlevel declines in the upper Yorktown-Eastover aquifer show that the increased withdrawals on the coast cause drawdowns of greater than $5 \mathrm{ft}$ to extend offshore. The area of reversed flow indicates a potential for downward vertical leakage of saltwater from the Chesapeake Bay and nearshore estuaries into the freshwater part of the upper Yorktown-Eastover aquifer. The amount of saltwater that is introduced into the freshwater system vertically through the confining unit is probably relatively small; however, salt concentrations could be high and could significantly affect the quality of the water withdrawn. This area is further complicated because of the present-day channel in the Chesapeake Bay (figs. 3 and 11). The upper Yorktown-Eastover confining unit probably has been eroded, and rates of saltwater intrusion could be increased because of a direct 


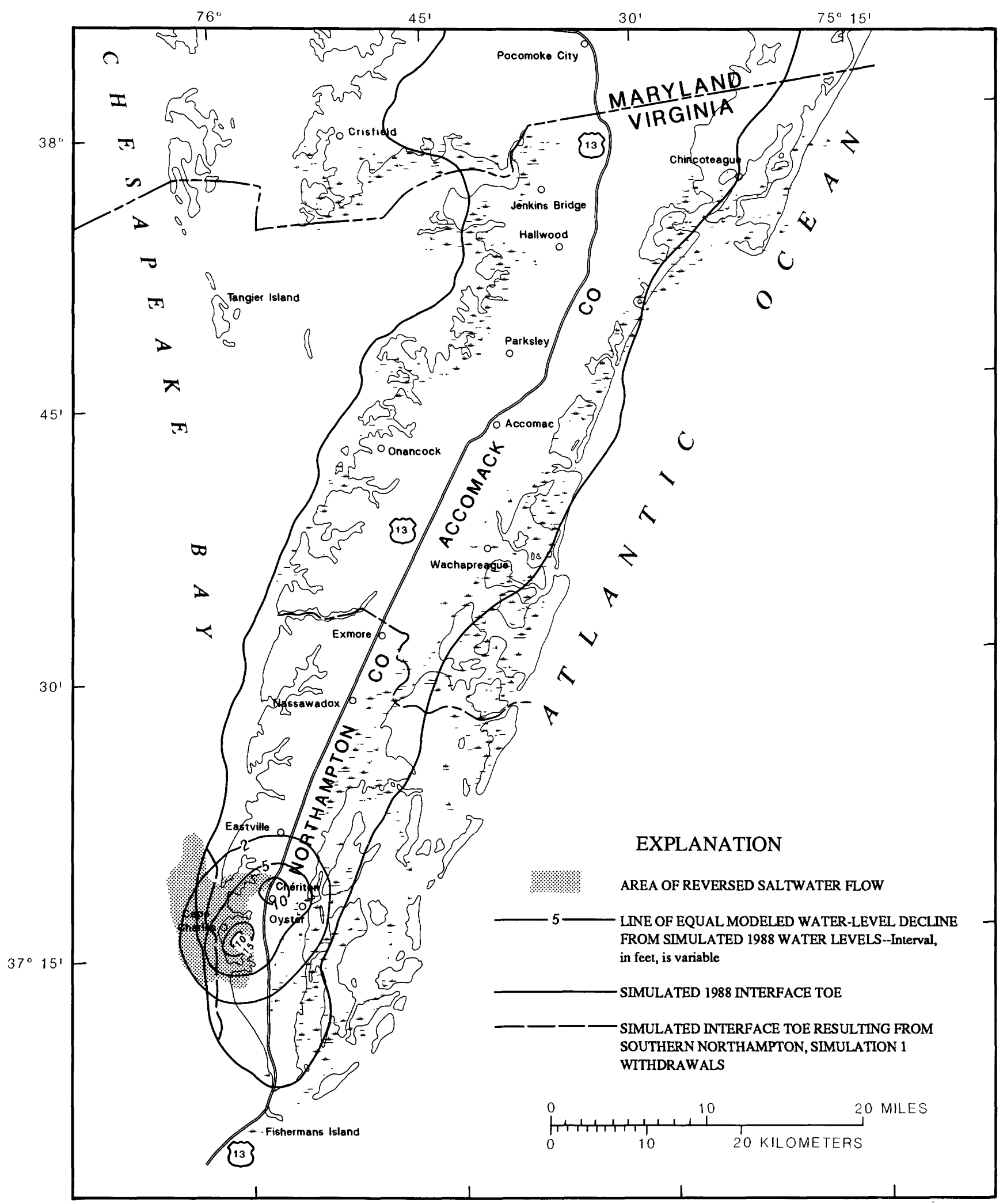

Figure 47. Water-level decline from simulated 1988 water levels, simulated position of the saltwater-freshwater interface toe, and area of reversed saltwater flow in the upper Yorktown-Eastover aquifer, southern Northampton County scenario, simulation 1. 


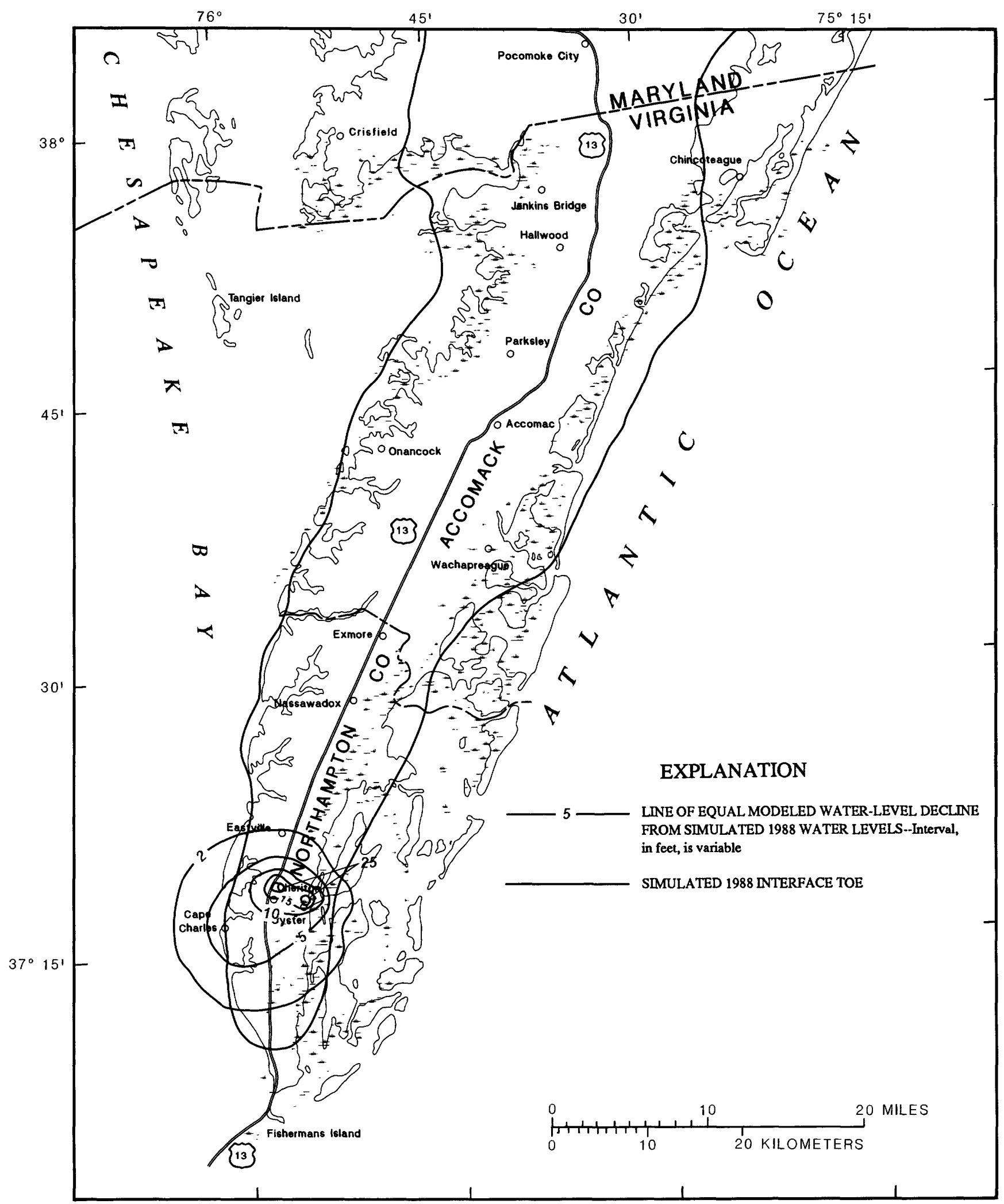

Figure 48. Water-level decline from simulated 1988 water levels and simulated position of the saltwater-freshwater interface toe in the middle Yorktown-Eastover aquifer, southern Northampton County scenario, simulation 1. 


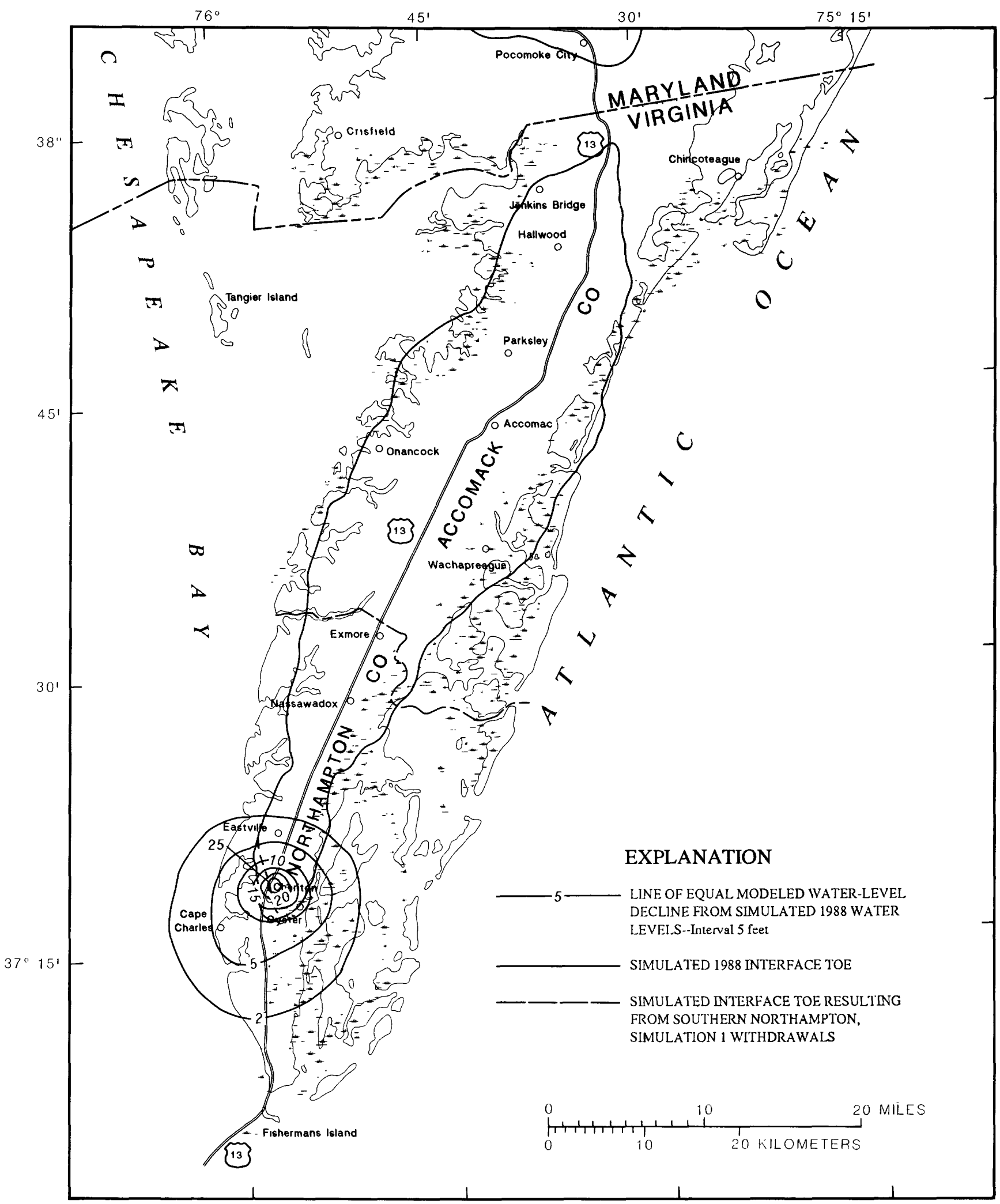

Figure 49. Water-level decline from simulated 1988 water levels and simulated position of the saltwater-freshwater interface toe in the lower Yorktown-Eastover aquifer, southern Northampton County scenario, simulation 1. 
connection between the upper Yorktown-Eastover aquifer and the saltwater in the Chesapeake Bay. The model results indicate that the hypothetical increase in pumpage in southern Northampton County at current well locations could create waterquality problems. Heavy pumpage along the coast in the upper Yorktown-Eastover aquifer could cause water levels to decline offshore and induce leakage of saltwater from the Chesapeake Bay into the freshwater part of the aquifer. The amount of waterquality degradation that could result from this process cannot be quantified by this study. Model results indicate that this is a potential concern and needs to be considered in future studies.

\section{Simulation 2}

In the second simulation, withdrawals are increased in southern Northampton County by the same amount as simulation 1; however, the withdrawals are removed from the coast and redistributed throughout Northampton County to hypothetical well fields in the center of the peninsula. The total withdrawal for the area is divided equally among 10 hypothetical well fields and is distributed equally among all three confined aquifers (table 20). Pumpage for the rest of the model area is held constant at the average pumping rate for the final pumping period in the historic transient simulation (1987-88). As in the previous simulation, the results of the transient simulation of 1988 conditions are used as initial conditions, and the simulation is continued for a period of 50 years. Withdrawals by aquifer are presented in table 18 for all of the model scenarios.

Modeled water-level declines from simulated 1988 water levels are shown in figures 50-52.

Declines are centered in the middle of the peninsula, and the maximum water-level declines are 8.0, 22.0 , and $22.4 \mathrm{ft}$ for the upper, middle, and lower Yorktown-Eastover aquifers, respectively (table 19). Since pumpage is no longer concentrated in the Cape Charles area, water-level declines are smaller in each aquifer for simulation 2 than they are in simulation 1. Water-level declines are greatest in the lower Yorktown-Eastover aquifer because transmissivities are smaller there than in the middle or upper Yorktown-Eastover aquifers. The placement of the wells in the center of the peninsula causes the water-level contours to follow the shape of the peninsula, and less drawdown occurs in offshore areas. As in simulation 1, the simulated water levels
Table 20. Location of southern Northampton scenario withdrawals, simulation 2

[Mgal/d, million gallons per day]

\begin{tabular}{ll}
\hline Grid location & $\begin{array}{l}\text { Withdrawal } \\
(\mathrm{Mgal} / \mathrm{d})\end{array}$ \\
\hline Row Column & Aquifer \\
\hline
\end{tabular}

\begin{tabular}{rrrr}
64 & 26 & 0.376 & Upper, middle, and lower Yorktown-Eastover \\
66 & 26 & .376 & Upper, middle, and lower Yorktown-Eastover \\
68 & 26 & .376 & Upper, middle, and lower Yorktown-Eastover \\
70 & 26 & .376 & Upper, middle, and lower Yorktown-Eastover \\
72 & 26 & .376 & Upper, middle, and lower Yorktown-Eastover \\
74 & 26 & .376 & Upper, middle, and lower Yorktown-Eastover \\
76 & 26 & .376 & Upper, middle, and lower Yorktown-Eastover \\
78 & 26 & .376 & Upper, middle, and lower Yorktown-Eastover \\
80 & 26 & .376 & Upper, middle, and lower Yorktown-Eastover \\
82 & 26 & .376 & Upper, middle, and lower Yorktown-Eastover \\
\hline
\end{tabular}

throughout the model area remain above the top of the aquifers.

The simulated ground-water budgets for the freshwater-flow system indicate recharge to the confined system increases by $1.52 \mathrm{Mgal} / \mathrm{d}$ over 1988 conditions, whereas natural discharge from the confined aquifers decreases by $1.35 \mathrm{Mgal} / \mathrm{d}$ from the simulated 1988 discharge rate (table 16). The change in flow through the system is a result of the $3.21 \mathrm{Mgal} / \mathrm{d}$ increase in freshwater withdrawals over 1988 rates. Although the total ground-water withdrawal for simulation 1 is identical to simulation 2 , the freshwater withdrawal is slightly less. The withdrawal locations in simulation 1 are near the coast and result in more withdrawal from the saltwaterflow system. A comparison of recharge and discharge for the two southern Northampton simulations shows that the same withdrawal amount and a different areal distribution can produce a change in the flux through the system. Slightly less water $(0.30 \mathrm{Mgal} / \mathrm{d})$ enters the confined system in simulation 2 , and slightly less water $(0.23 \mathrm{Mgal} / \mathrm{d})$ is discharged naturally from the confined system. The decrease in flow through the system in simulation 2 is balanced by a small increase in the amount of water that is released from aquifer storage (table 16).

Slight landward movement of the simulated saltwater-freshwater interface from the 1988 position occurs during the 50-year transient simulation in the upper Yorktown-Eastover aquifer (fig. 50). The interface position for the middle and lower Yorktown-Eastover aquifers does not change from 


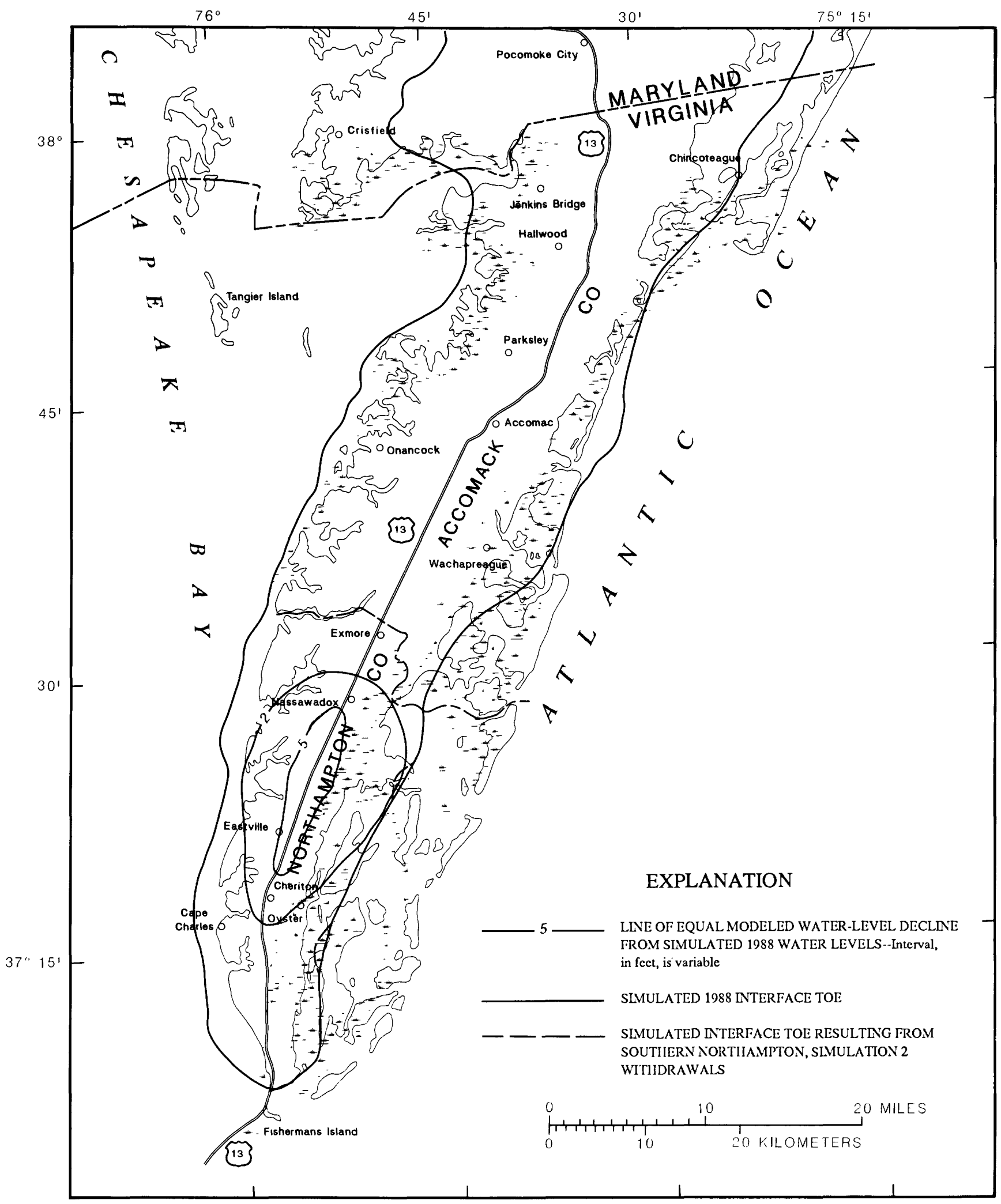

Figure 50. Water-level decline from simulated 1988 water levels and simulated position of the saltwater-freshwater interface toe in the upper Yorktown-Eastover aquifer, southern Northampton County scenario, simulation 2. 


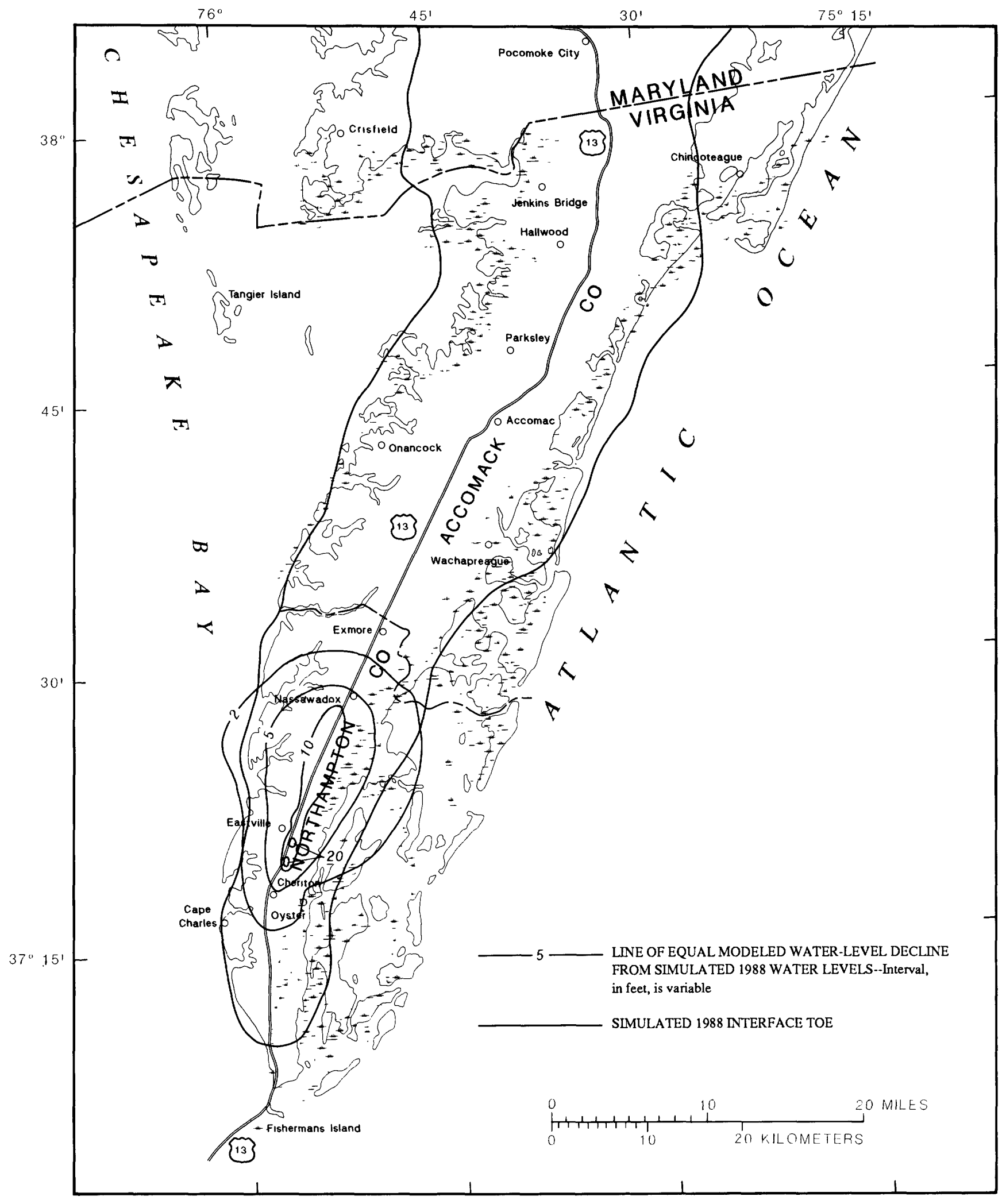

Figure 51. Water-level decline from simulated 1988 water levels and simulated position of the saltwater-freshwater interface toe in the middle Yorktown-Eastover aquifer, southern Northampton County scenario, simulation 2. 


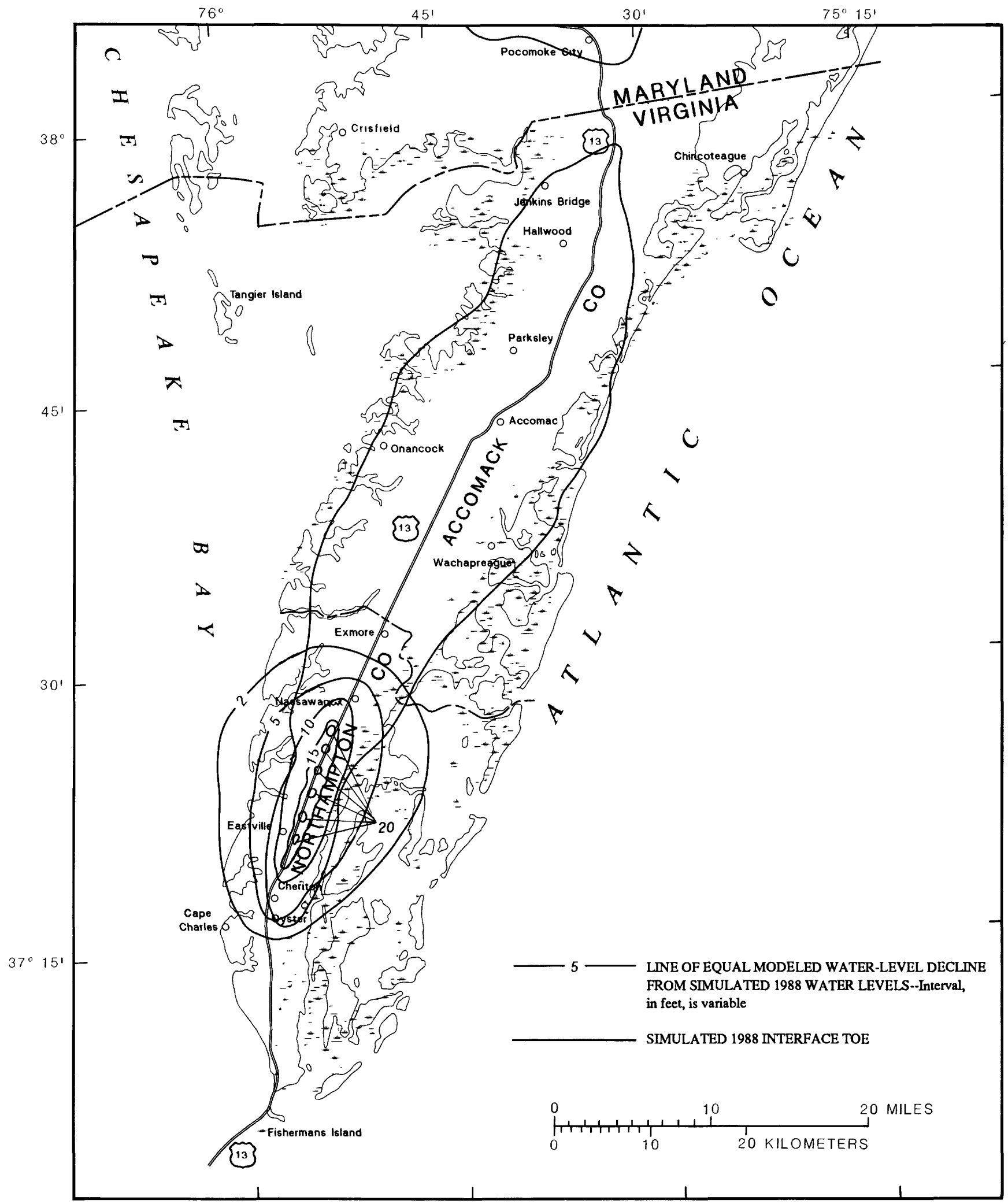

Figure 52. Water-level decline from simulated 1988 water levels and simulated position of the saltwater-freshwater interface toe in the lower Yorktown-Eastover aquifer, southern Northampton County scenario, simulation 2. 
the 1988 position. The simulated interface toe moves landward a maximum of approximately 0.5 $\mathrm{mi}$ in the upper Yorktown-Eastover aquifer.

Although the position of the interface does not move as much as it did in simulation 1 , this model result illustrates the sensitivity of the fresh-ground-water system in southern Northampton County. The additional withdrawal of $3.21 \mathrm{Mgal} / \mathrm{d}$ results in some movement of the saltwater-freshwater interface in the uppermost confined aquifer, even with well fields placed as far away from the interface as possible. The peninsula in this area is narrow (4-5 $\mathrm{mi}$ wide), which limits its ability to sustain large ground-water withdrawals.

Simulated water levels show that saltwater intrusion into the uppermost confined aquifer through downward vertical leakage does not occur when withdrawals are distributed equally to all three aquifers and placed in the center of the peninsula. Freshwater is flowing from the upper YorktownEastover aquifer; water-level declines offshore are not large enough to reverse the hydraulic gradient and induce saltwater leakage through the confining unit.

\section{Northeastern Accomack County Scenario}

Chincoteague Island is a popular tourist location in northeastern Accomack County that requires a large supply of freshwater in the summer months. This area is on the easternmost boundary of the Eastern Shore's freshwater-flow system and has a high potential for water-quality degradation by saltwater intrusion. The northeastern part of Accomack County has several major ground-water users, and in this scenario, the response of the ground-water-flow system to increased withdrawals is examined.

Two simulations are included in this scenario in order to evaluate model-boundary effects. The scenario consists of large increases in withdrawals over calibrated 1988 conditions in the northeastern corner of the model grid. At this level of withdrawal, the effects of the increased stress extend to the northern and eastern boundary of the model; therefore, the results of the simulation are affected by the model-boundary conditions. The boundary effects were quantified by simulating two different types of boundary conditions. In simulation 1 , a no-flow boundary (no water available across the boundary) is used to represent the most severe case, namely, maximum water-level decline. In simulation
2, a constant-head boundary (an unlimited supply of water across the boundary) is used to represent a less severe case, or minimum water-level decline. The response of the actual ground-water system would most likely fall somewhere between the two cases.

The initial conditions for both 50-year transient simulations of increased withdrawals in northeastern Accomack County are provided by the results of the transient simulation of 1988 conditions. Withdrawal locations are near the shore of the peninsula (fig. 53); the total hypothetical withdrawal for the area is $3.5 \mathrm{Mgal} / \mathrm{d}$ (table 21), an increase of $2.05 \mathrm{Mgal} / \mathrm{d}$ over 1988 withdrawals. Approximately 31,63 , and 6 percent of the total withdrawals come from the upper, middle, and lower YorktownEastover aquifers, respectively (table 18). Pumpage for the rest of the model area was held constant at the average pumping rate for the final pumping period in the historic transient simulation (1987-88). The withdrawals for these scenarios are concentrated in the upper two aquifers because the area is too far east to obtain good-quality water from the lower Yorktown-Eastover aquifer. Many of the withdrawals in this area come from the unconfined aquifer, which is not included in this model; therefore, the pumpage for simulations 1 and 2 is lower than the total projected increase for the northeastern part of Accomack County.

\section{Simulation 1: No-Flow Boundary}

The results of simulation 1 show that modeled water levels decline from simulated 1988 water levels throughout much of the northern model area (figs. 54-56). The maximum water-level declines are 17.2, 29.7, and $26.4 \mathrm{ft}$ for the upper, middle, and lower Yorktown-Eastover aquifers, respectively (table 19). The location of the maximum water-level decline is near the town of Hallwood for all three aquifers. Simulated water levels are above the tops of the aquifers, indicating that the dewatering of the confined aquifers is not a concern for this simulation.

The simulated ground-water budget for the freshwater-flow system is presented in table 16 . The increase in freshwater withdrawals of $2.05 \mathrm{Mgal} / \mathrm{d}$ over 1988 amounts results in a $1.07 \mathrm{Mgal} / \mathrm{d}$ increase in flow into the confined system and a $0.53 \mathrm{Mgal} / \mathrm{d}$ decrease in natural flow out of the confined system. 


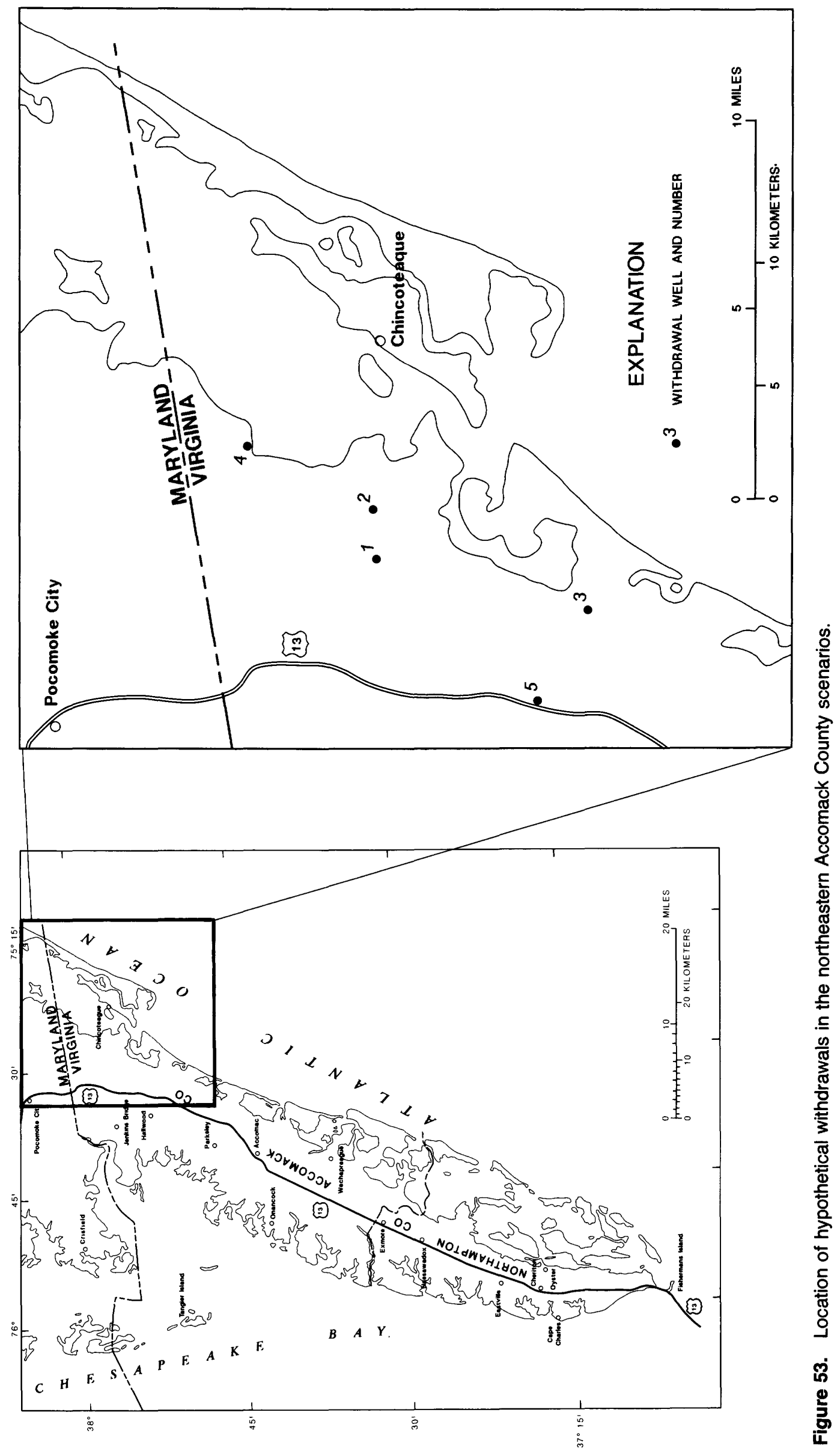


Table 21. Hypothetical withdrawals for the northeastern Accomack County scenario

[Mgal/d, million gallons per day; latitude and longitude are reported in degrees, arc minutes, arc seconds]

\begin{tabular}{llrrl}
\hline $\begin{array}{l}\text { Map } \\
\text { number }\end{array}$ & Latitude & Longitude & $\begin{array}{l}\text { Withdrawal } \\
\text { (Mgal/d) }\end{array}$ & $\begin{array}{l}\text { Yorktown-Eastover } \\
\text { aquifer penetrated }\end{array}$ \\
\hline 1 & 375626 & 0752844 & 0.314 & Upper, middle \\
2 & 375626 & 0752723 & 1.217 & Upper, middle \\
3 & 375134 & 0753041 & .128 & Upper \\
4 & 375911 & 0752528 & .055 & Upper, middle \\
5 & 375256 & 0753324 & 1.800 & Upper, middle, and lower \\
\hline
\end{tabular}

${ }^{1}$ Locations shown on figure 53.

Simulation of the increase in withdrawals in the northeastern part of Accomack County with a no-flow boundary condition results in a slight landward movement of the simulated saltwaterfreshwater interface in the upper and middle Yorktown-Eastover aquifers (figs. 54-56). The interface toe moves approximately $0.5 \mathrm{mi}$ landward in the upper and middle Yorktown-Eastover aquifers. The interface position in the lower YorktownEastover aquifer does not change from the simulated 1988 position during this 50 -year simulation.

Simulated water levels indicate several areas in northern Accomack County where offshore waterlevel declines resulting from the hypothetical increase in ground-water withdrawal have caused a reversal in ground-water flow from 1988 conditions (fig. 54). There is a potential for downward vertical leakage of saltwater into the freshwater part of the upper Yorktown-Eastover aquifer as a result of the increase in withdrawals in northeastern Accomack County.

\section{Simulation 2: Constant-Head Boundary}

Simulation 2 is identical to simulation 1 except that the northern and northeastern grid boundaries in simulation 2 are represented by a constant-head boundary instead of a no-flow boundary. The water levels for the boundary nodes are held constant at the simulated 1988 values of the nearest nodes. This type of boundary condition provides an unlimited source of water; therefore, the results indicate smaller head declines in simulation 2 than in simulation 1 from an increase in pumpage.

The water-level declines for the constant-head simulation are presented in figures 57-59. Comparison with figures 54-56 shows water-level declines north and northeast of the pumping center are less in the constant-head simulation (simulation 2) than in the no-flow simulation (simulation 1). Although the boundary conditions influence water levels in the north and northeastern part of the model area, water-level declines in the Virginia part of the Eastern Shore are similar for both simulations, indicating that the boundary conditions do not greatly affect results in the study area. The maximum water-level declines are $15.8,27.9$, and $24.6 \mathrm{ft}$ in the upper, middle, and lower Yorktown-Eastover aquifers, respectively (table 19). The location of the maximum water-level declines is near the town of Hallwood for all three aquifers. The maximum water-level declines in simulation 2 differ from those in simulation 1 by less than $2 \mathrm{ft}$ in all three aquifers. As in simulation 1, the water levels are above the tops of the aquifers throughout the model area.

The amount of ground-water flow through the system in simulation 2 is affected by the constanthead boundary condition (table 16). The flow into the confined system for simulation 2 decreases by $0.27 \mathrm{Mgal} / \mathrm{d}$ over simulated 1988 conditions, even though withdrawals are increased by $2.05 \mathrm{Mgal} / \mathrm{d}$. The boundary nodes are supplying the water needed for the increase in withdrawal. A comparison of the results of the two simulations in the northeastern part of Accomack County further indicates the effects of the different boundary conditions. The flow into the confined system through the uppermost confining unit in simulation 2 is $1.34 \mathrm{Mgal} / \mathrm{d}$ less than the flow into the confined system for simulation 1. The pumpage in both simulations is identical. In simulation 1 (no-flow boundary), the source of the water withdrawn is increased recharge and decreased discharge, whereas in simulation 2 (constant-head boundary), much of the water withdrawn is derived from flow from the boundary nodes.

The simulated position of the saltwaterfreshwater interface toe for simulation 2 (figs. 57-59) is similar to the interface-toe position for simulation 1 (figs. 54-56). Changing the boundary conditions from a no-flow to a constant-head boundary in this situation does not affect the groundwater-flow system enough to cause a substantial difference in the movement of the saltwater-freshwater interface during the 50-year simulation. The saltwater-freshwater interface for simulation 2 in the upper Yorktown-Eastover aquifer does not move landward for as long a distance along the coast as it 


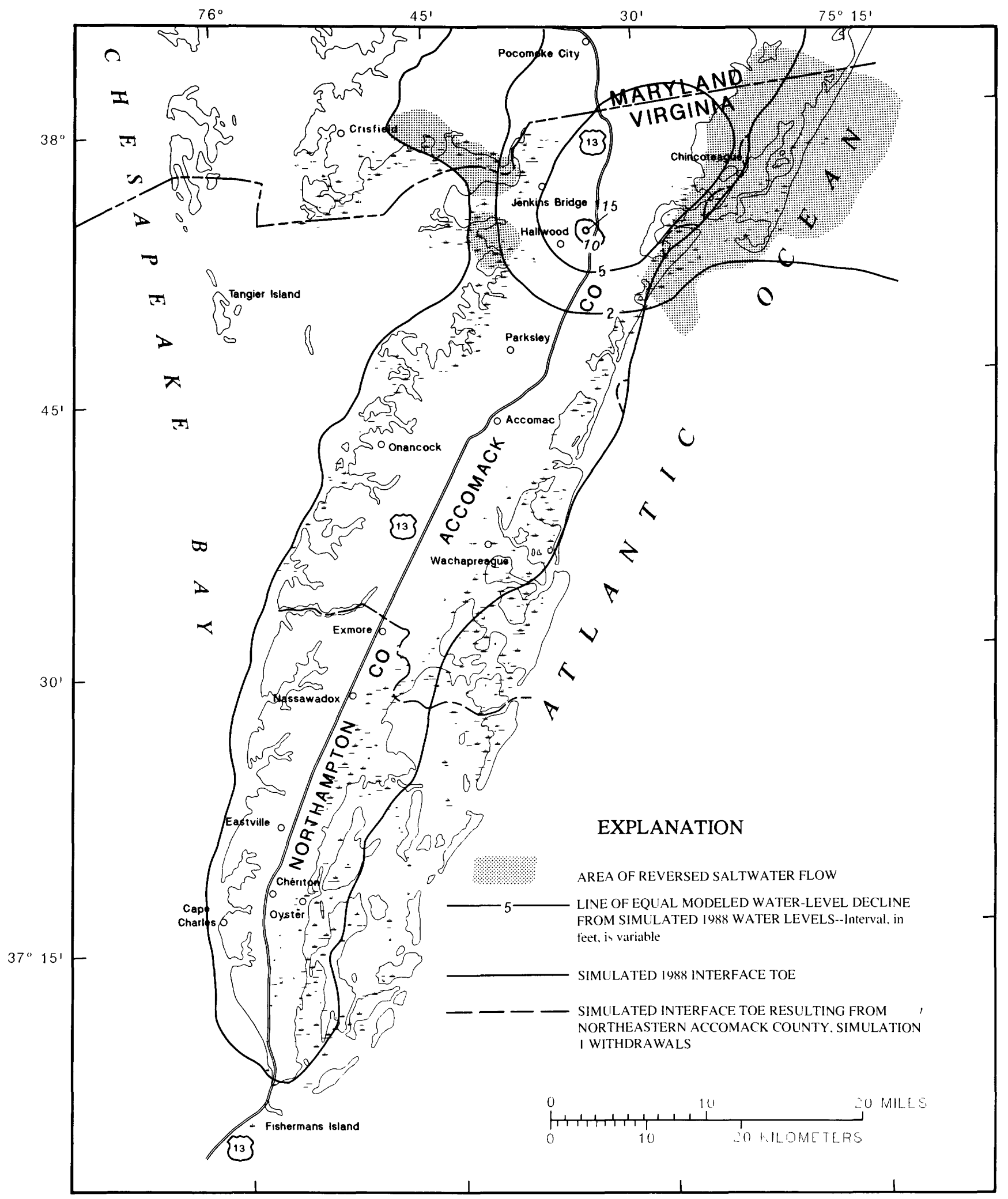

Figure 54. Water-level decline from simulated 1988 water levels, simulated position of the saltwater-freshwater interface toe, and area of reversed saltwater flow in the upper Yorktown-Eastover aquifer, northeastern Accomack County scenario, simulation 1. 


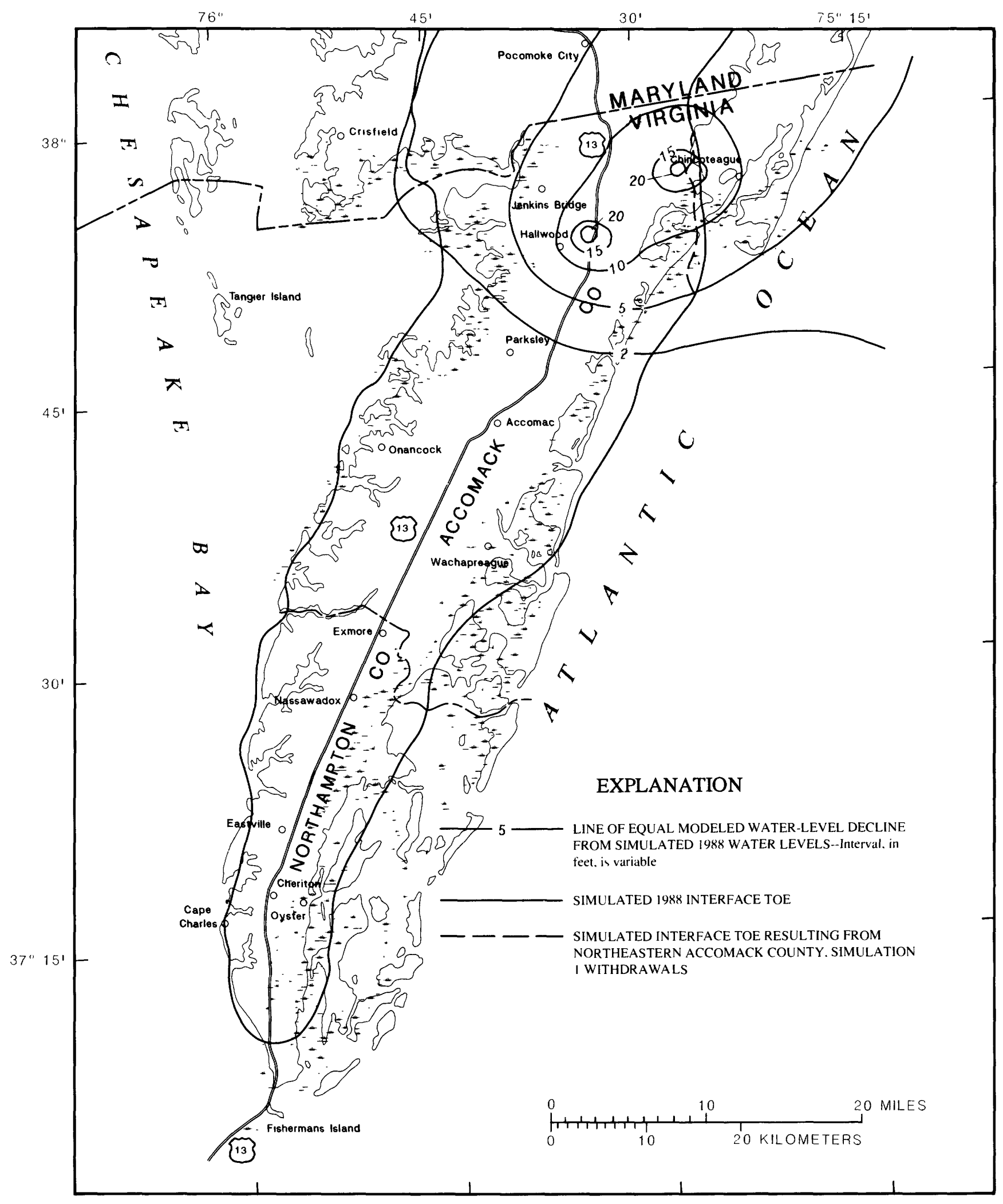

Figure 55. Water-level decline from simulated 1988 water levels and simulated position of the saltwater-freshwater interface toe in the middle Yorktown-Eastover aquifer, northeastern Accomack County scenario, simulation 1. 


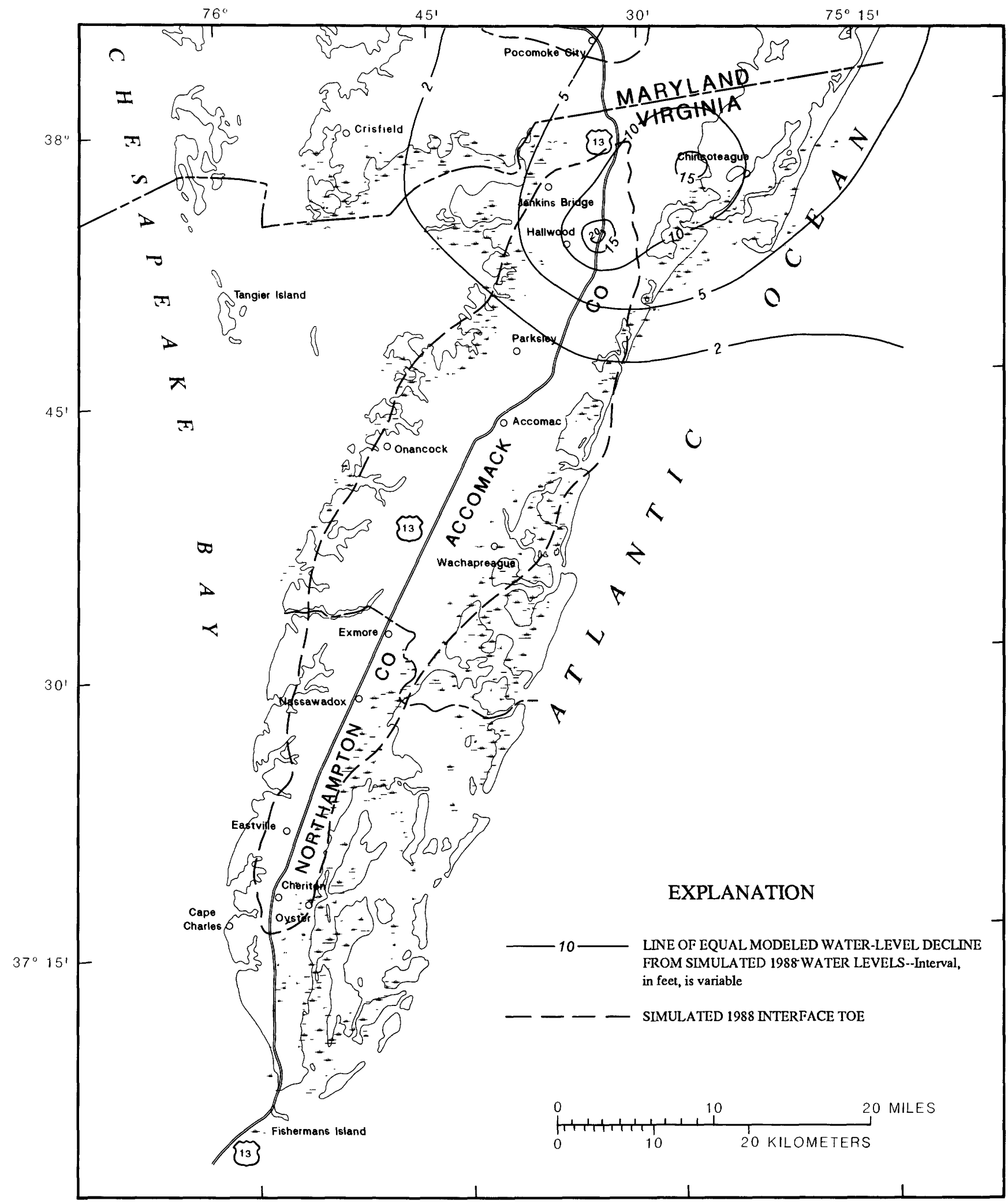

Figure 56. Water-level decline from simulated 1988 water levels and simulated position of the saltwater-freshwater interface toe in the lower Yorktown-Eastover aquifer, northeastern Accomack County scenario, simulation 1. 


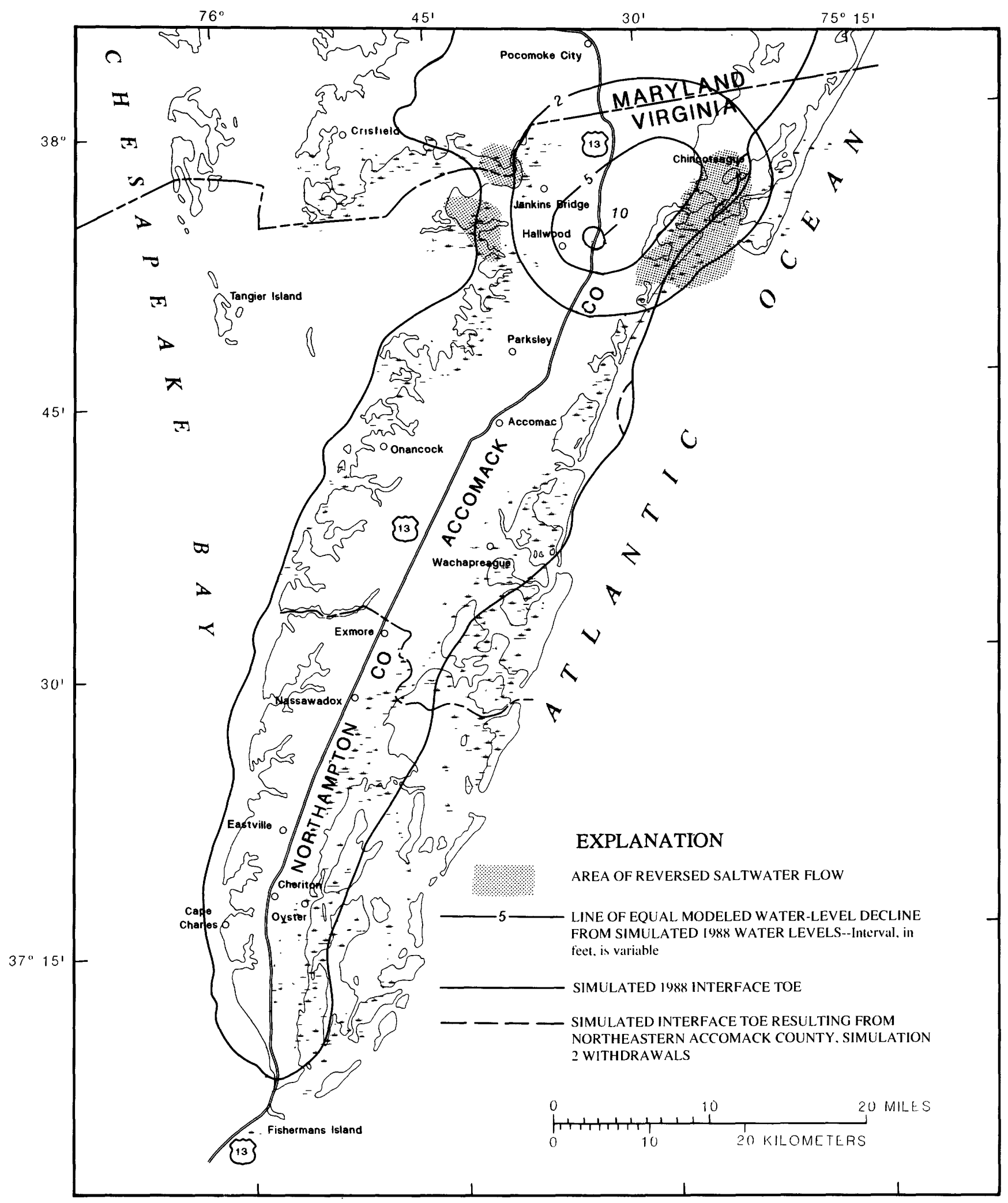

Figure 57. Water-level decline from simulated 1988 water levels, simulated position of the saltwater-freshwater interface toe, and area of reversed saltwater flow in the upper Yorktown-Eastover aquifer, northeastern Accomack County scenario, simulation 2. 


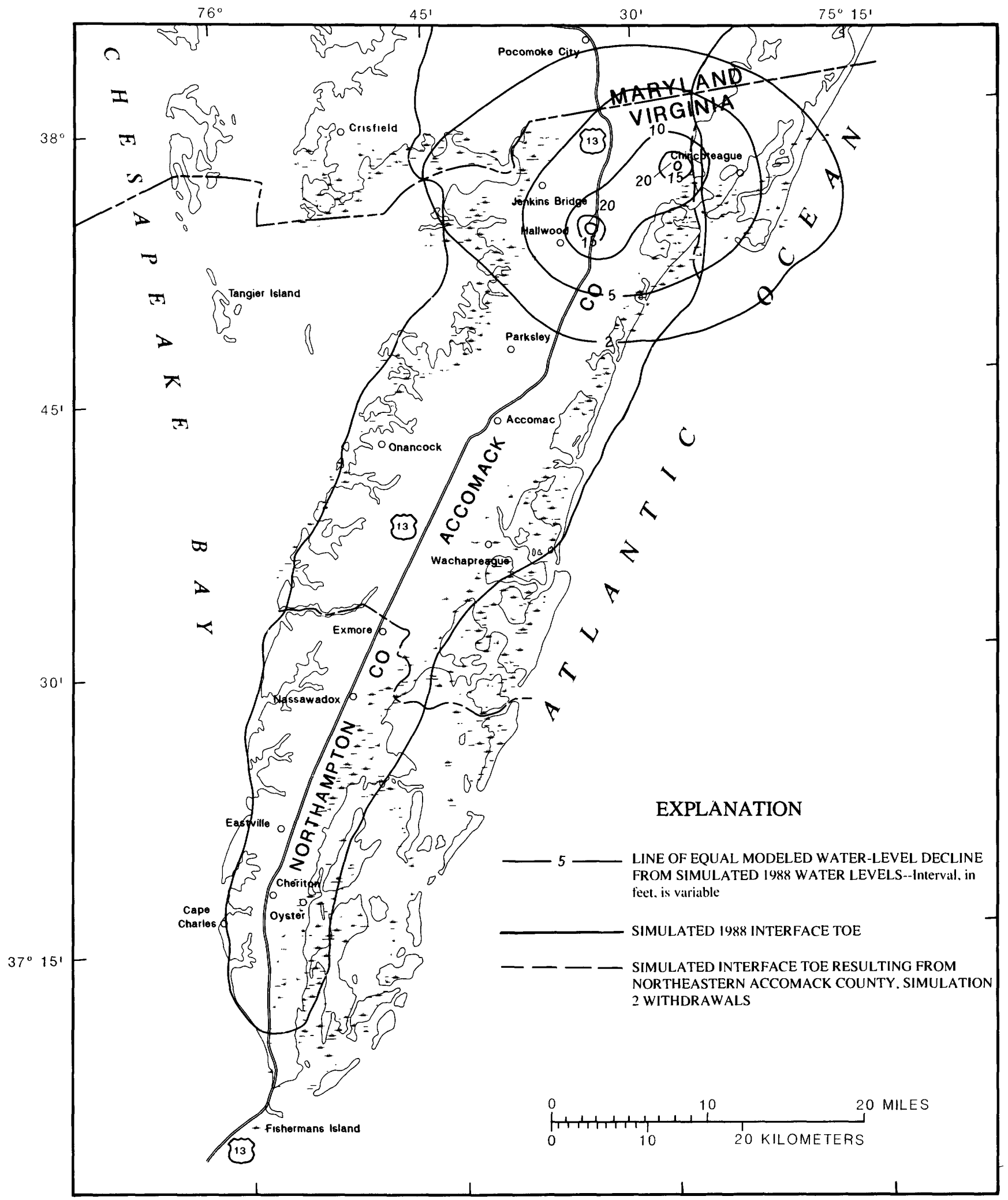

Figure 58. Water-level decline from simulated 1988 water levels and simulated position of the saltwater-freshwater interface toe in the middle Yorktown-Eastover aquifer, northeastern Accomack County scenario, simulation 2. 


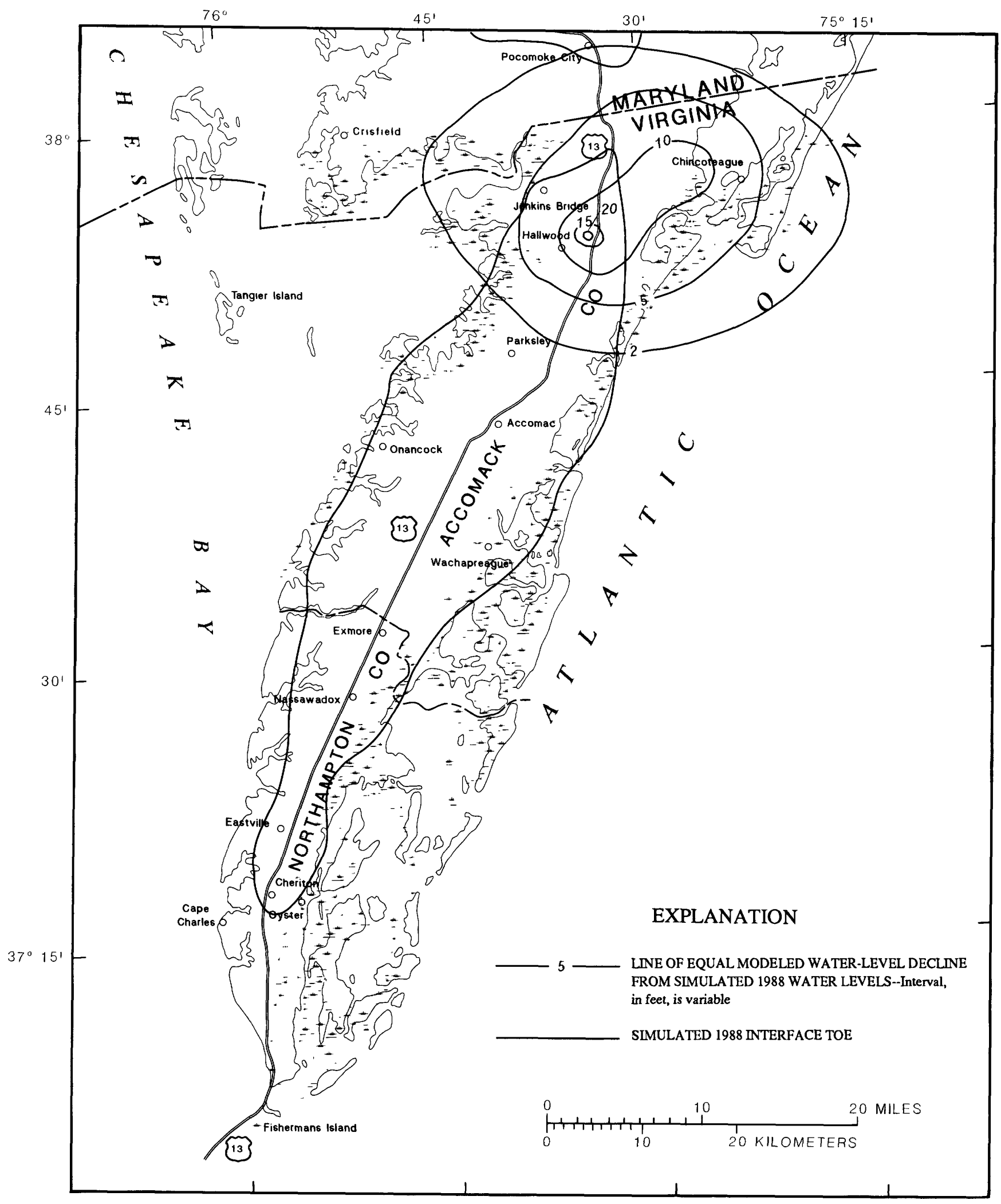

Figure 59. Water-level decline from simulated 1988 water levels and simulated position of the saltwater-freshwater interface toe in the lower Yorktown-Eastover aquifer, northeastern Accomack County scenario, simulation 2. 
Table 22. Permitted withdrawals as of January 1, 1990

[Latitude and longitude are reported in degrees, arc minutes, arc seconds; Mgal/d, million gallons per day]

\begin{tabular}{|c|c|c|c|c|}
\hline $\begin{array}{l}\text { Map } \\
\text { number }{ }^{2}\end{array}$ & Facility & Latitude & Longitude & $\begin{array}{l}\text { Permitted } \\
\text { withdrawal } \\
\text { (Mgal/d) }\end{array}$ \\
\hline 1 & Accomack Nursing Home & 374528 & 0753721 & 0.029 \\
\hline 2 & American Original & 373045 & 0754828 & .250 \\
\hline 3 & Bayshore Concrete & 371540 & 0760121 & .125 \\
\hline 4 & Byrd Foods & 374530 & 0754010 & .600 \\
\hline 5 & C\&D Seafood & 371711 & 0755524 & .152 \\
\hline 6 & Custis Enterprises & 372150 & 0755522 & .441 \\
\hline 7 & Dicanio & 371336 & 0760019 & .047 \\
\hline 8 & Dicanio & 371314 & 0760021 & .047 \\
\hline 9 & Dicanio & 371353 & 0755923 & .093 \\
\hline 10 & Dicanio & 371354 & 0755908 & .093 \\
\hline 11 & Eastem Shore Seafood & 375121 & 0753337 & .300 \\
\hline 12 & Exmore Foods & 373201 & 0754916 & 2.001 \\
\hline 13 & Holly Farms & 375256 & 0753324 & 1.800 \\
\hline 14 & JW Taylor Packing & 375239 & 0753527 & .549 \\
\hline 15 & KMC Food & 371746 & 0755728 & 1.600 \\
\hline 16 & NASA, Wallops Island & 375134 & 0753041 & .127 \\
\hline 17 & NASA, main base & 375626 & 0752844 & .263 \\
\hline 18 & New Church Energy & 375823 & 0753213 & .336 \\
\hline 19 & Peaceful Beach & 373105 & 0755650 & .229 \\
\hline 20 & Perdue & 374429 & 0753920 & 2.639 \\
\hline 21 & H. Allen Smith & 371715 & 0755512 & .150 \\
\hline 22 & Town of Cape Charles & 371605 & 0760019 & .260 \\
\hline 23 & Town of Chincoteague & 375626 & 0752723 & 1.340 \\
\hline 24 & Town of Exmore & 373231 & 0754914 & .320 \\
\hline
\end{tabular}

${ }^{1}$ Locations shown on figure 60 .

does in simulation 1. The maximum amount of landward movement is approximately $0.5 \mathrm{mi}$ in each simulation. The movement of the interface in the middle Yorktown-Eastover aquifer is identical for both the no-flow and the constant-head simulations (figs. 55 and 58). The location of the saltwaterfreshwater interface toe in simulation 2 remains unchanged from 1988 conditions for the lower Yorktown-Eastover aquifer.

Simulated water levels indicate several areas of reversed ground-water flow (fig. 57) where there is potential for induced downward vertical leakage of saltwater into the freshwater parts of the upper Yorktown-Eastover aquifer. A comparison with the area of reversed flow from simulation 1 (fig. 54) shows that simulation 2 identifies a smaller area of potential induced saltwater leakage. The area of reversed ground-water flow is smaller for simulation 2 than simulation 1 because the water-level decline is reduced as a result of the unlimited supply of water from the constant-head boundary. The results of simulation 2 indicate that, even when an infinite amount of water is allowed through the northern and eastern boundaries, saltwater intrusion through downward vertical leakage is possible, given the hypothetical projected increase in ground-water withdrawal in northeastern Accomack County.

\section{Permitted-Withdrawal Scenario}

The final scenario presented in this report examines the ground-water-flow system's response to currently (1990) permitted withdrawals. In 1976, the State of Virginia established Accomack and Northampton Counties as a Ground-Water Management Area. Thus, all nonagricultural ground-water users withdrawing more than $300,000 \mathrm{gal} /$ month must obtain a permit from the VWCB. As of 1990, most of the permitted ground-water users on the Eastern Shore were withdrawing less water than their permits allowed. In this scenario, ground-water conditions are simulated that would result from increasing withdrawal on the Eastern Shore to 1990 permitted levels.

Permitted withdrawal amounts as of January 1,1990 , ranged from 0.029 to $2.639 \mathrm{Mgal} / \mathrm{d}$ (table 22). Permitted withdrawals are widely spread 
over the northern and southern ends of the peninsula (fig. 60). Withdrawals for ground-water users that do not have permits were continued at 1988 rates. Pumpage for the permitted scenario (13.824 Mgal/d) represents a 173 percent increase $(8.763 \mathrm{Mgal} / \mathrm{d})$ over 1988 withdrawals (table 18). Simulated 1988 conditions were used as initial conditions for a 100 year transient simulation of 1990 permitted withdrawals. Although water levels respond quickly to changes in stress, the movement of the saltwaterfreshwater interface takes place over long periods of time. The simulation was carried out to 100 years to provide insight into the long-term effects of increased withdrawals on the movement of the saltwater-freshwater interface.

Modeled water-level decline from simulated 1988 water levels is shown in figures 61-63. Waterlevel declines exceed $25 \mathrm{ft}$ in the upper YorktownEastover aquifers and $65 \mathrm{ft}$ in the middle and lower Yorktown-Eastover aquifers. A maximum waterlevel decline of approximately $95 \mathrm{ft}$ occurs in the middle Yorktown-Eastover aquifer near the town of Exmore (table 19). Water levels remain above the tops of the aquifers, indicating from a regional perspective that dewatering would be minimal at permitted-withdrawal levels.

The permitted-withdrawal scenario involves a greater increase in withdrawals over 1988 pumpage than any of the previous scenarios; therefore, the changes in the flow into and out of the confined system are the most dramatic (table 16). The increase in freshwater withdrawals of $8.65 \mathrm{Mgal} / \mathrm{d}$ over 1988 amounts results in an increase in flow into the confined-aquifer system by $4.33 \mathrm{Mgal} / \mathrm{d}$ and a decrease in natural flow out of the confinedaquifer system by $2.99 \mathrm{Mgal} / \mathrm{d}$.

The position of the simulated saltwaterfreshwater interface for the 100-year transient permitted-withdrawal scenario is shown in figures 61-63. Interface movement coincides with the areas of greatest water-level decline due to increased pumpage. Maximum inland movement of the saltwater-freshwater interface toe is approximately $1 \mathrm{mi}$ in the upper Yorktown-Eastover aquifer near the town of Cape Charles and in the middle Yorktown-Eastover aquifer near the town of Chincoteague. Maximum inland movement of the interface toe is approximately $1 \mathrm{mi}$ in the lower Yorktown-Eastover aquifer near the town of Hallwood. The water-quality effects on the width of the mixing zone between saltwater and freshwater can- not be simulated by the sharp-interface model. The chloride concentrations in the mixing zone probably fluctuate more rapidly than the position of the sharp interface.

Water-level declines caused by pumpage in nearshore and coastal areas indicate several areas of reversed ground-water flow from the Atlantic Ocean and Chesapeake Bay to the freshwater parts of the upper Yorktown-Eastover aquifer (fig. 61). The areas of reversed flow indicate a potential for vertical leakage of saltwater into the freshwater parts of the upper Yorktown-Eastover aquifer. The rate of vertical leakage of saltwater is highly dependent on the vertical hydraulic conductivity of the upper Yorktown-Eastover confining unit in the vicinity of the flow reversal.

\section{Discussion of Model Results}

The model results from the three scenarios of increased ground-water withdrawals provide information on the regional response of the ground-water system to additional stress and its ability to meet future water needs. The simulations are not intended to predict exact ground-water conditions in the future; however, a comparison of model results provides useful information for the evaluation of alternative withdrawal scenarios.

The distribution of ground-water withdrawals directly affects the ability of the ground-water system to sustain increased withdrawals without incurring saltwater intrusion. An increase in ground-water withdrawals lowers ground-water levels around the pumping centers. Ground-water flow is diverted to the major pumping centers; water from adjacent parts of the aquifer and from adjacent aquifers or confining units replaces the water withdrawn. Large water-level declines could necessitate lowering of pump intakes, could increase the rate of movement of the offshore interface between saltwater and freshwater, and could induce leakage of poor-quality water from adjacent aquifers or surface-water bodies. Excessive head declines and detrimental effects on water quality can be minimized with proper well placement. Withdrawal wells can be placed in areas that would minimize interference with other major ground-water users.

Any increase in withdrawals from the confined freshwater aquifers on the Eastern Shore increases the amount of recharge to and decreases the amount of natural discharge from the confined-aquifer system 


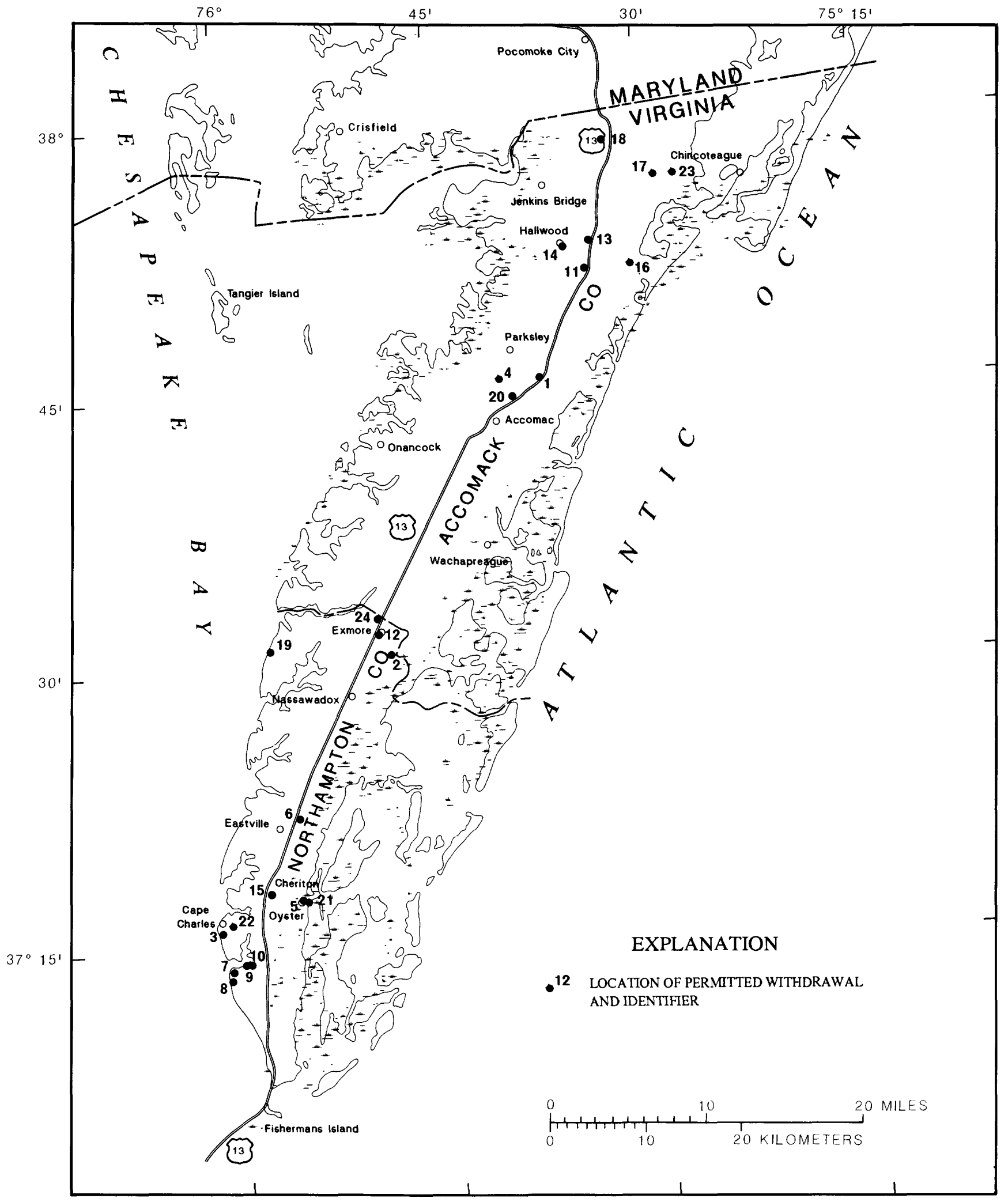

Figure 60. Location of permitted withdrawals. 


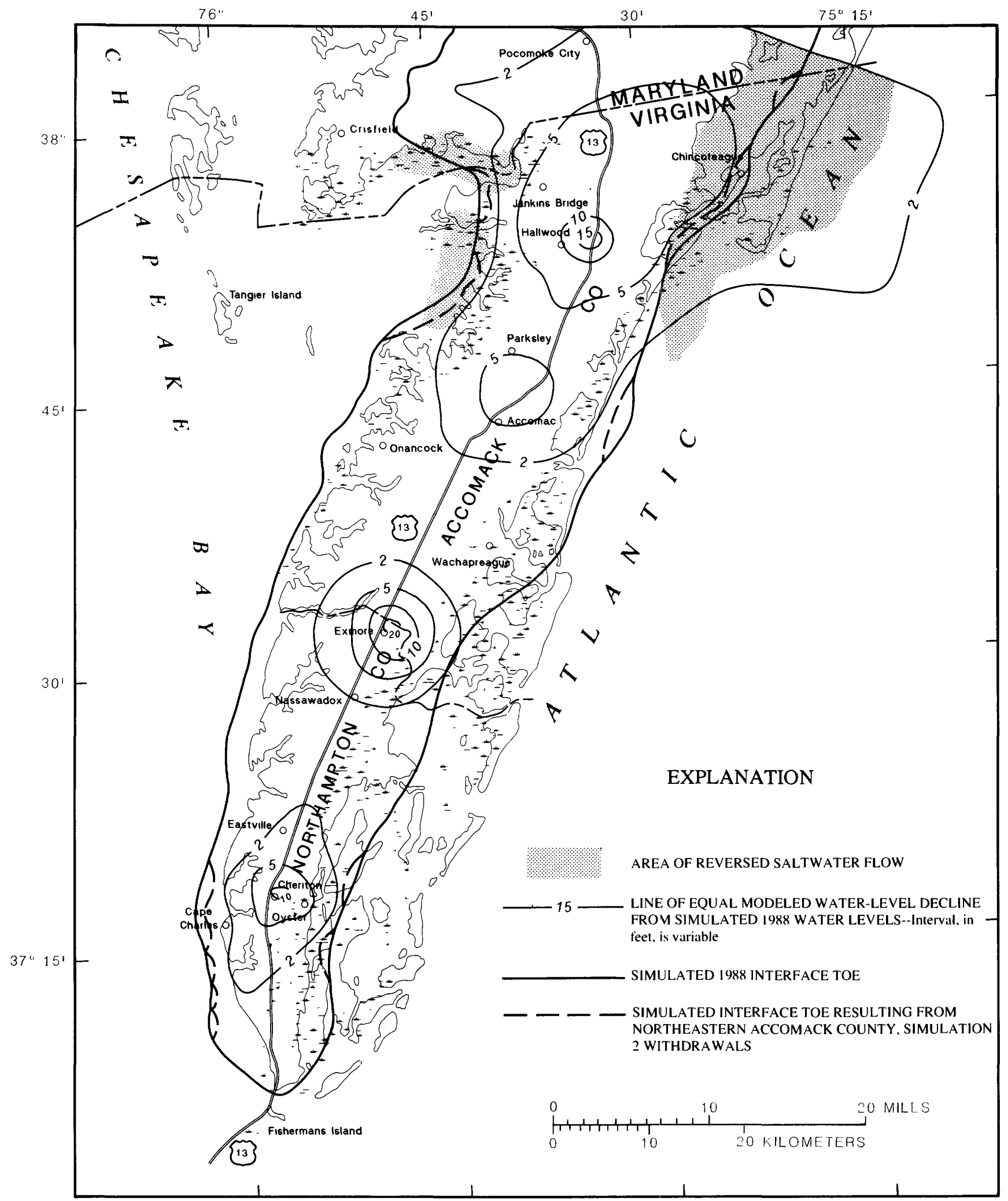

Figure 61. Water-level decline from simulated 1988 water levels, simulated position of the saltwater-freshwater interface toe, and area of reversed saltwater flow in the upper Yorktown-Eastover aquifer, permitted-withdrawal scenario. 


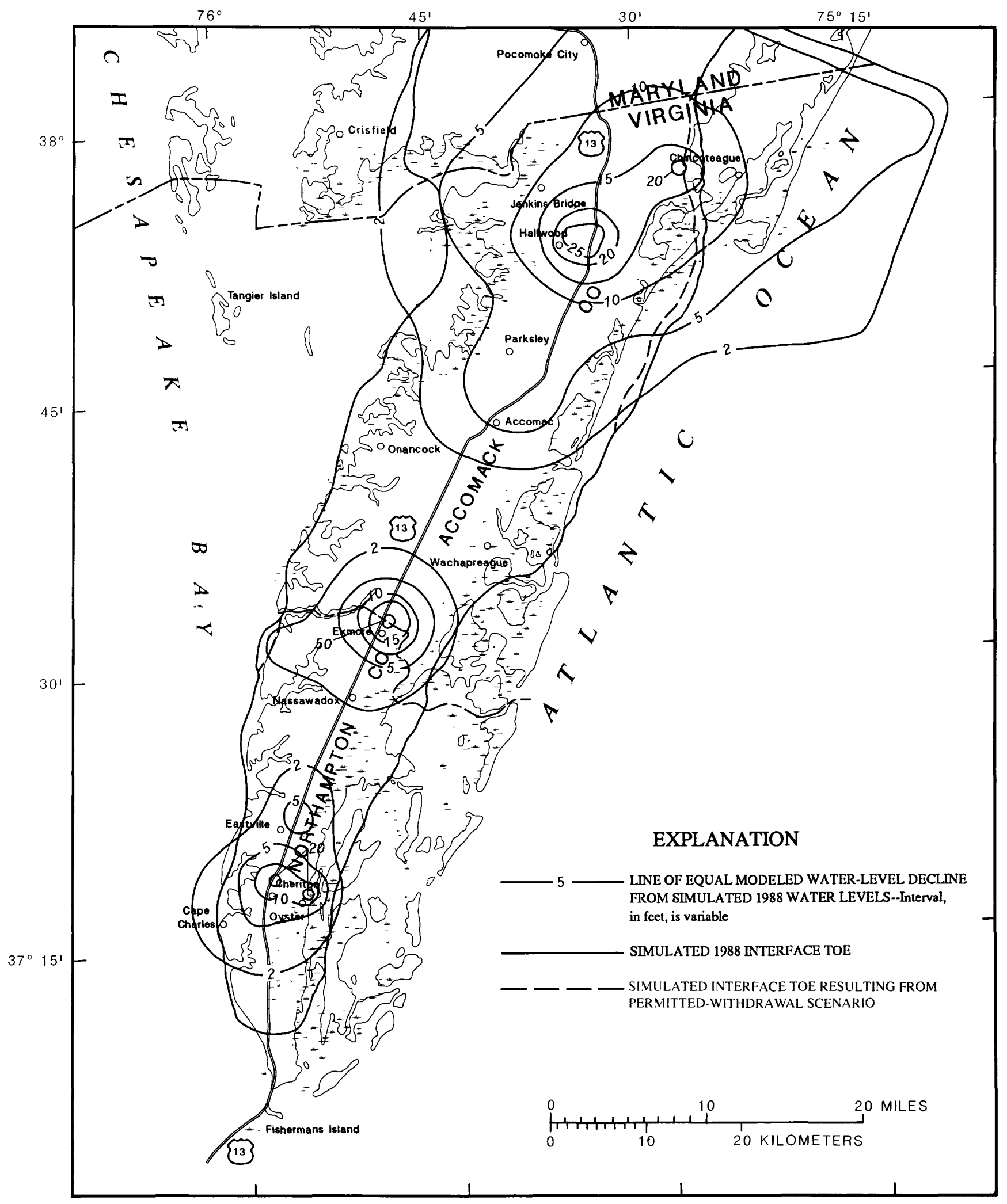

Figure 62. Water-level decline from simulated 1988 water levels and simulated position of the saltwater-freshwater interface toe in the middle Yorktown-Eastover aquifer, permitted-withdrawal scenario. 


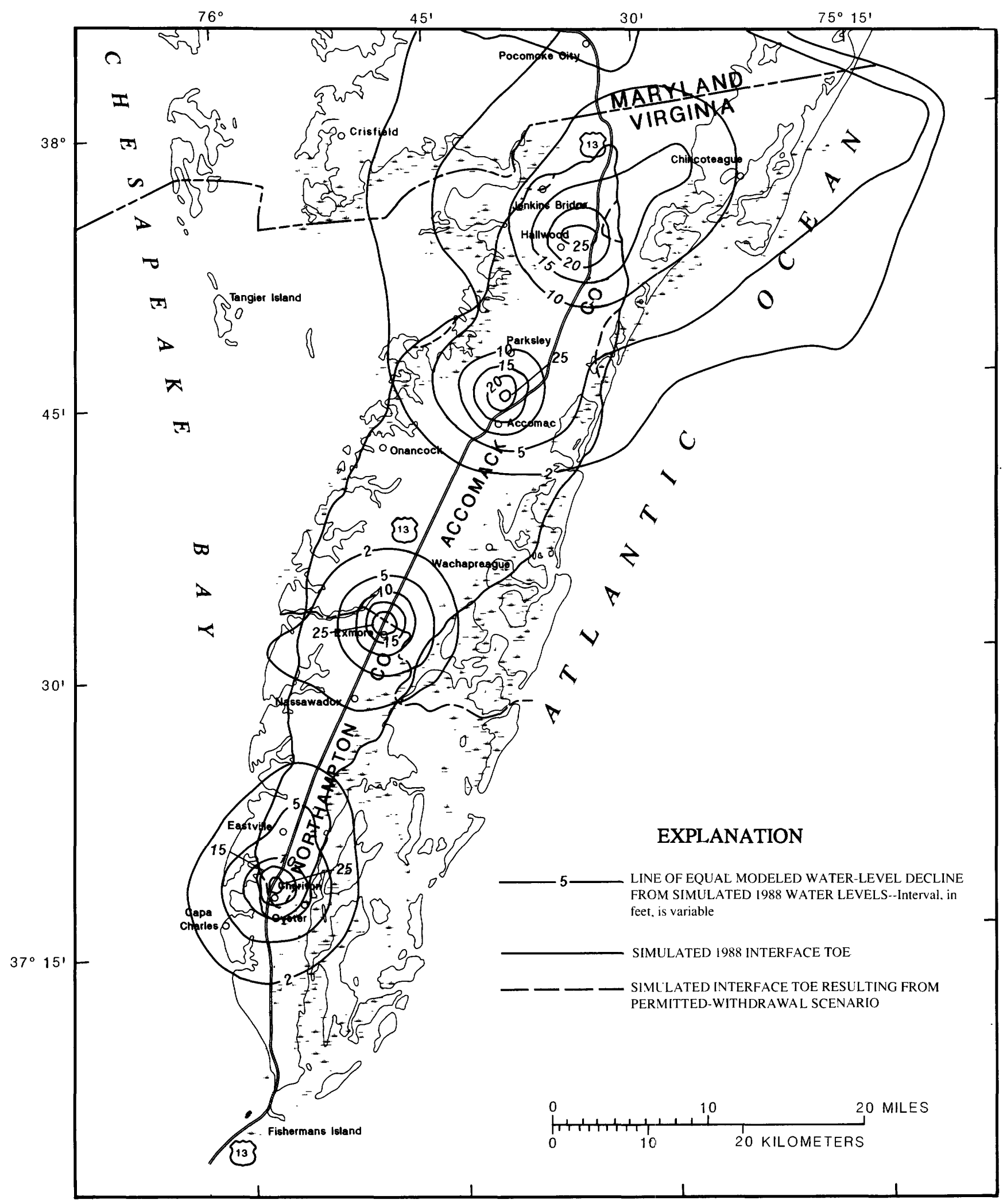

Figure 63. Water-level decline from simulated 1988 water levels and simulated position of the saltwater-freshwater interface toe in the lower Yorktown-Eastover aquifer, permitted-withdrawal scenario. 
A reduction in freshwater discharge to the Chesapeake Bay and Atlantic Ocean changes the equilibrium between the freshwater and the surrounding saltwater. The interface between freshwater and saltwater begins to move inland as saltwater replaces the withdrawn freshwater. A reduction in freshwater discharge also could affect salinity levels at freshwater-discharge sites in nearshore inlets, bays, and estuaries.

Model results indicate that water-level declines in close proximity to the simulated location of the saltwater-freshwater interface have the most dramatic effect on the rate of interface movement. Large water-level declines in the center of the peninsula have a minimal effect on the rate of movement of the saltwater-freshwater interface; however, small water-level declines in coastal areas adjacent to the interface position cause a noticeable increase in the rate of interface movement.

Two potential pathways for saltwater intrusion into the freshwater aquifers of the Eastern Shore were examined in this report. Model simulations show saltwater intrusion through lateral movement of the saltwater-freshwater interface and through downward vertical leakage of saltwater in areas where a saltwater source overlies the freshwater part of the uppermost confined aquifer. Model simulations indicate that lateral movement of the saltwaterfreshwater interface is slow and takes place over long periods of time. However, a reversal of the ground-water-flow direction can take place in short timeframes and could result in induced vertical leakage of saltwater through the confining unit into the freshwater part of an aquifer. Areas of reversed flow of saltwater into freshwater areas are seen in scenario results where heavy withdrawals are present in coastal areas and water-level declines extend offshore.

\section{Sensitivity Analysis}

Model-sensitivity analyses were conducted to examine the response of the calibrated model to changes in boundary conditions and estimated hydraulic characteristics. The model sensitivity to the northern no-flow boundary condition is illustrated in the section of this report describing simulation 2 of the northeastern Accomack County scenario. Model runs also were conducted to determine the sensitivity of the model to changes in the overlying constant-head boundary. Increasing the overly- ing constant heads (that represent the water table) resulted in a slight increase in the heads in the simulated confined aquifers. Correspondingly, decreasing the overlying constant heads resulted in lower heads in the simulated confined aquifers. The hydraulic property that dominates flow through the system is the vertical leakance of the uppermost confining unit, and as a result, the model is more sensitive to changes in confining-unit vertical leakance than it is to changes in the overlying constant heads. The results of the sensitivity analysis of the calibrated model to changes in horizontal hydraulic conductivity of aquifers and leakance of confining units are presented in this section. Sensitivity simulations were conducted by increasing or decreasing an individual parameter while all other characteristics remained unchanged. The larger the resulting changes in water levels are, the more sensitive the model is to that parameter, and the smaller the change, the less sensitive the model is.

Withdrawal conditions from simulation 1 of the southern Northampton County scenario were used to examine the model's sensitivity to large increases in withdrawals. Variations in hydraulic characteristics were compared by simulating a 50-percent increase and decrease in hydraulic conductivity and vertical leakance. Water-level differences that resulted from changing the calibrated hydraulic parameters are shown in figures 64-67. The maximum water-level changes for each aquifer for each sensitivity run (table 23) show that the model is most sensitive near major pumping areas. Generally, the water levels simulated by the model are more sensitive to decreases than they are to increases in hydraulic conductivity and vertical leakance. The responses of the saltwater-freshwater interface to changes in hydraulic conductivity and vertical leakance were slow and not sensitive over the 50-year simulation period. Increasing hydraulic conductivity and decreasing vertical leakance result in an interface position that is slightly closer to the shore in a few locations than the calibrated-scenario interface position. Decreasing hydraulic conductivity and increasing vertical leakance result in an interface position that is slightly farther offshore in a few locations than the calibrated scenario.

\section{Model Limitations}

The ground-water-flow model developed for the Eastern Shore is a tool that was used to assist in 


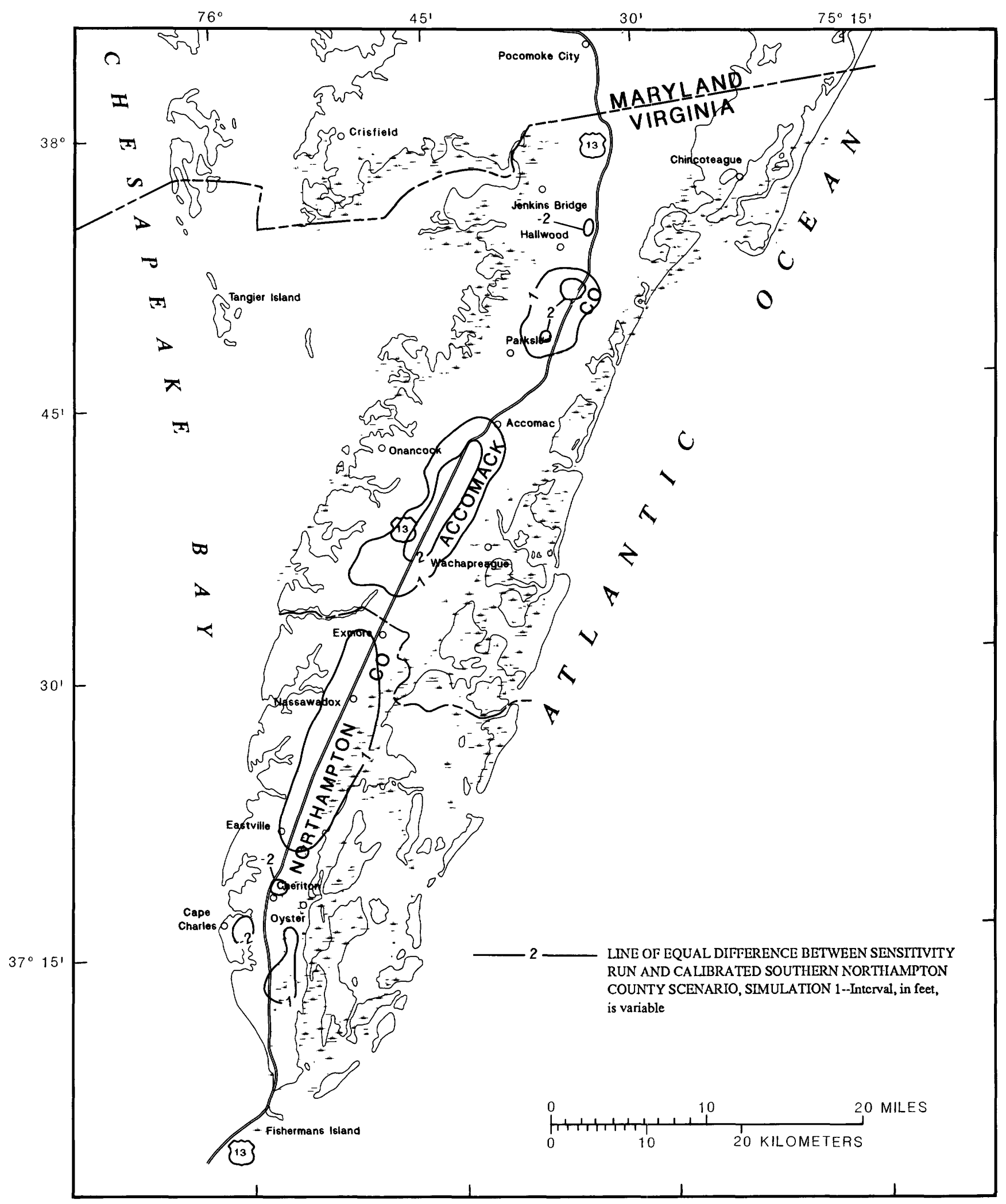

Figure 64. Difference in simulated water levels resulting from a 50-percent increase in horizontal hydraulic conductivity for the southern Northampton County scenario-simulation 1, upper Yorktown-Eastover aquifer. 


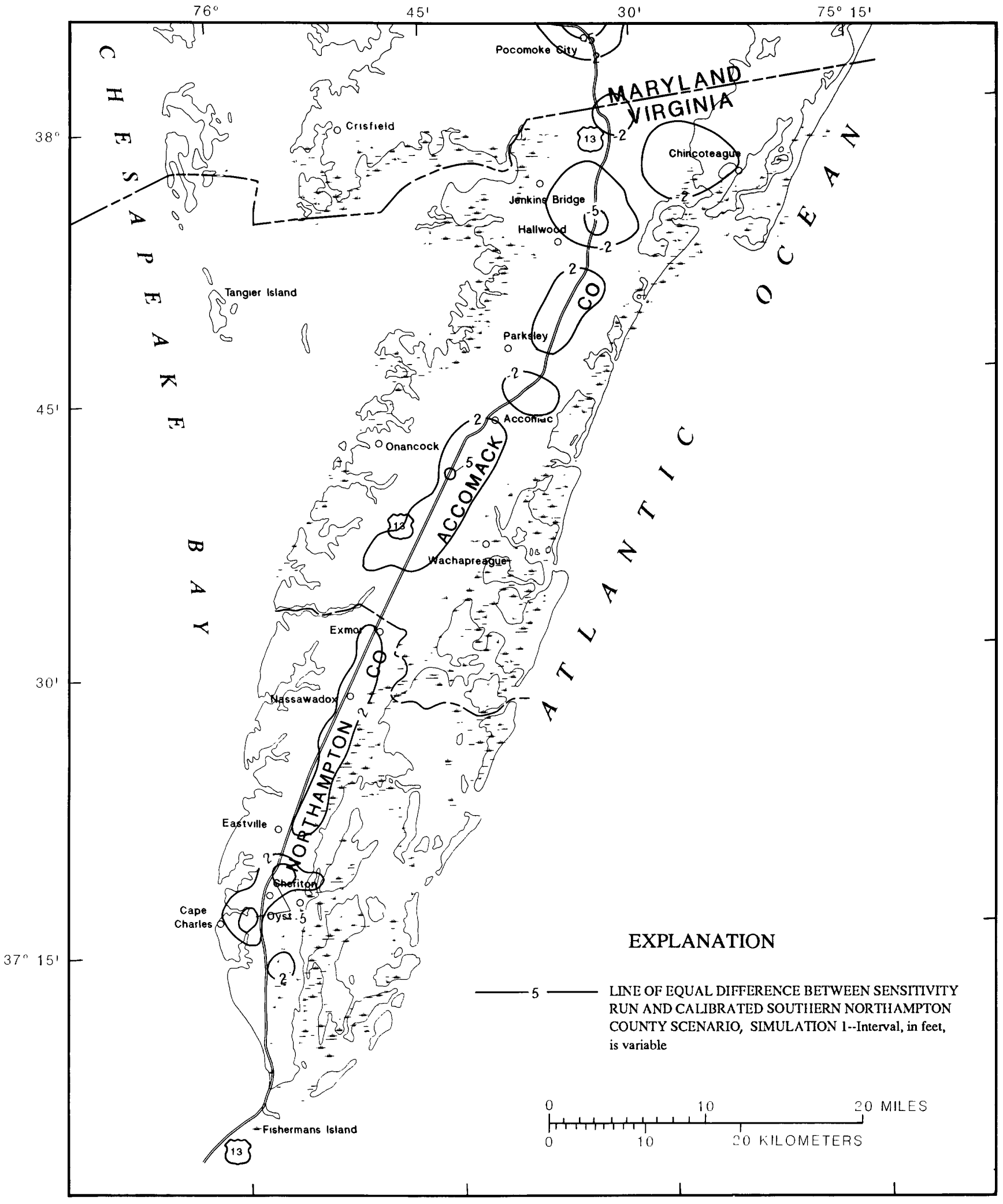

Figure 65. Difference in simulated water levels resulting from a 50-percent decrease in horizontal hydraulic conductivity for the southern Northampton County scenario-simulation 1, upper Yorktown-Eastover aquifer. 


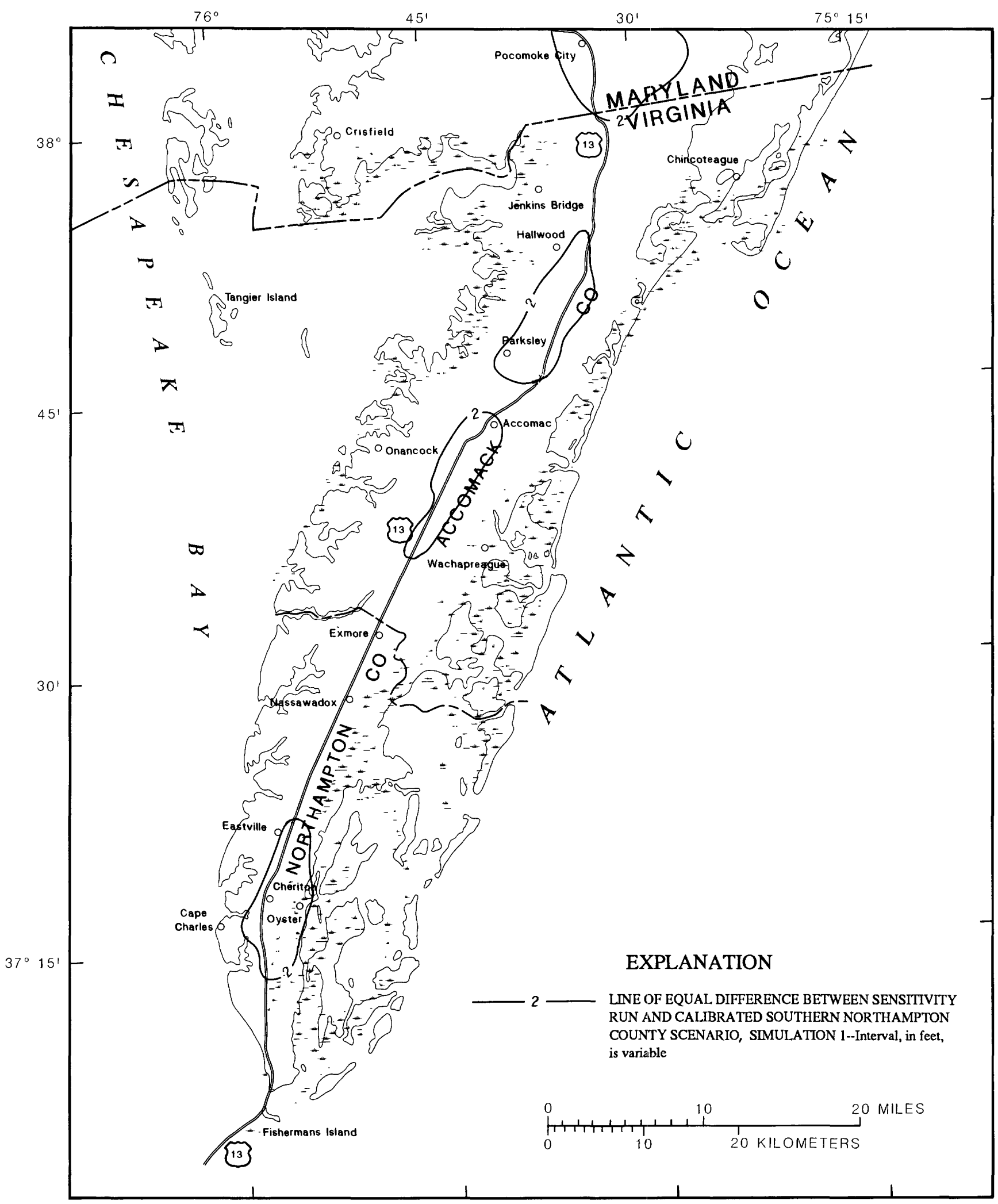

Figure 66. Difference in simulated water levels resulting from a 50-percent increase in confining unit leakance for the southern Northampton County scenario-simulation 1, upper Yorktown-Eastover aquifer. 


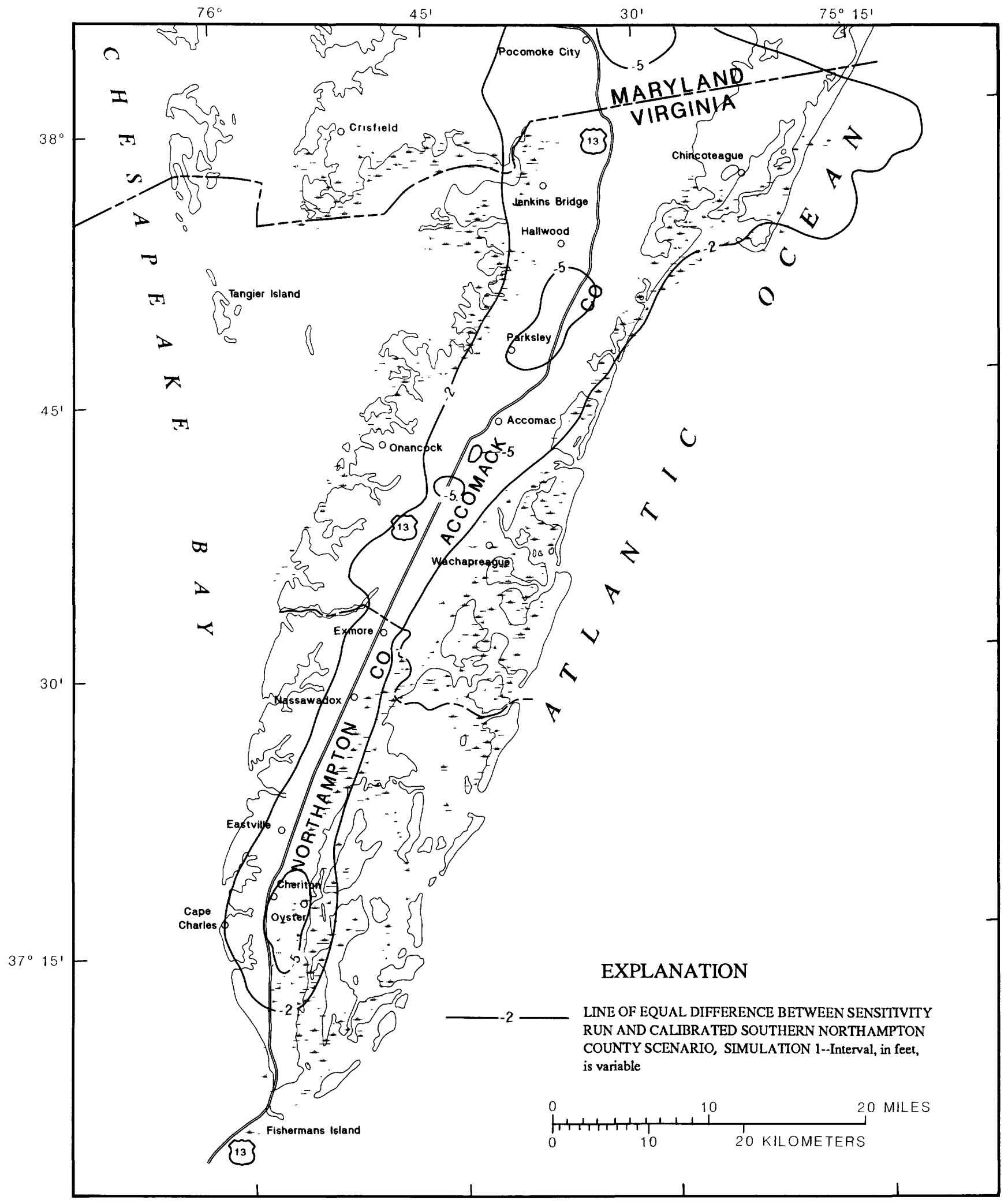

Figure 67. Difference in simulated water levels resulting from a 50-percent decrease in confining unit leakance for the southern Northampton County scenario-simulation 1, upper Yorktown-Eastover aquifer. 
Table 23. Maximum water-level changes resulting from sensitivity runs

\begin{tabular}{|c|c|c|c|c|c|c|}
\hline & \multirow{2}{*}{$\begin{array}{l}\text { Maximum } \\
\text { water-level } \\
\text { increase } \\
\text { (feet) }\end{array}$} & \multicolumn{2}{|c|}{ Grid location of increase } & \multirow{2}{*}{$\begin{array}{l}\text { Maximum } \\
\text { water-level } \\
\text { decline } \\
\text { (feet) }\end{array}$} & \multicolumn{2}{|c|}{ Grid location of decrease } \\
\hline & & Row & Column & & Row & Column \\
\hline \multicolumn{7}{|c|}{ 50-percent increase in hydraulic conductivity } \\
\hline Upper Yorktown-Eastover & 4.0 & 3 & 27 & -3.5 & 43 & 28 \\
\hline Middle Yorktown-Eastover & 10.5 & 80 & 29 & -3.3 & 45 & 28 \\
\hline Lower Yorktown-Eastover & 14.6 & 80 & 26 & -3.2 & 45 & 29 \\
\hline \multicolumn{7}{|c|}{ 50percent decrease in hydraulic conductivity } \\
\hline Upper Yorktown-Eastover & 5.8 & 43 & 28 & -10.7 & 3 & 27 \\
\hline Middle Yorktown-Eastover & 5.4 & 43 & 29 & -24.5 & 80 & 29 \\
\hline Lower Yorktown-Eastover & 5.5 & 45 & 29 & -39.5 & 80 & 26 \\
\hline \multicolumn{7}{|c|}{ 50-percent increase in confining unit leakance } \\
\hline Upper Yorktown-Eastover & 3.6 & 30 & 31 & -1.5 & 58 & 42 \\
\hline Middle Yorktown-Eastover & 7.6 & 80 & 29 & -2.3 & 60 & 43 \\
\hline Lower Yorktown-Eastover & 5.6 & 80 & 26 & -3.0 & 57 & 40 \\
\hline \multicolumn{7}{|c|}{ 50-percent decrease in confining unit leakance } \\
\hline Upper Yorktown-Eastover & 1.0 & 51 & 39 & -6.7 & 29 & 33 \\
\hline Middle Yorktown-Eastover & .9 & 66 & 37 & -13.9 & 80 & 29 \\
\hline Lower Yorktown-Eastover & 1.0 & 63 & 37 & -10.0 & 80 & 26 \\
\hline
\end{tabular}

the analysis of the ground-water-flow system. The model is an approximate representation of a complex physical system. The hydrogeologic characteristics of a conceptualized three-dimensional system of aquifers and confining units are integrated in the model. Stresses can be applied to this quasi-threedimensional representation of the system, and the relative effects of those stresses on the water levels, the water budget, and the saltwater-freshwater interface can be examined.

The model was developed to simulate regional effects of hydrologic stresses on the ground-waterflow system. The large spatial and temporal scale of the model makes it unsuitable for the analysis of local effects, short-term effects, and small-scale withdrawals. A small-scale analysis of the flow system would require spatial and temporal refinement of the aquifer and confining-unit characteristics and hydrologic stresses.

The model simulates ground-water flow in the Eastern Shore's freshwater-bearing confined aquifers, from which the majority of withdrawals are made. The water table in the unconfined aquifer was specified in the model as a constant-head boundary to simulate the regional recharge-discharge relation between the unconfined aquifer and the confined system, but flow in the unconfined aquifer was not simulated. The deep, saltwater aquifers (approximately $300 \mathrm{ft}$ below land surface) also are not simulated by the model. As of 1990, no water was being pumped from the deep aquifers in the study area.

The saltwater-freshwater interface is represented in the model as a sharp interface. There are no offshore data for the Eastern Shore; therefore, the actual position of the saltwater-freshwater interface and the width of the transition zone are unknown. Saltwater and freshwater are simulated as immiscible fluids, and mixing due to hydrodynamic dispersion is neglected. Leakage between the saltwater and freshwater zone is restricted by the model. Saltwater is not allowed to leak into the freshwater zone. The leakage of freshwater is distributed between the saltwater and freshwater zones based on the amounts of each type of water in the node receiving the leakage. The approach is designed to reproduce the general response of the interface and does not provide information concerning the nature of the transition zone between saltwater and freshwater. Vertical leakage of saltwater into freshwater is not directly simulated; evidence of vertical saltwater intrusion from overlying saltysurface-water bodies is provided by examination of 
the water-level gradients and areas of reversed ground-water flow. The model is not able to simulate upconing of saltwater as a result of pumpage. This approach is considered an initial step in the process of characterizing the interactions between saltwater and freshwater around the Eastern Shore. Data concerning the dispersive properties of the sediments and a solute-transport-modeling approach to the saltwater-freshwater interface are needed to fully characterize the water quality in the transition zone between saltwater and freshwater.

The location of the historical and present-day saltwater-freshwater interface is not known. The model simulates the location of the interface by simulating saltwater and freshwater flow and balancing pressures along the interface. The historic prestressed position of the interface is assumed, for the purposes of this report, to be in equilibrium with present-day sea levels. However, the interface position may not have reached an equilibrium position and may still be responding to long-term sea-level fluctuations.

\section{SUMMARY}

The Eastern Shore of Virginia is totally dependent on ground water for its freshwater supply. Increased pumpage due to intensifying agricultural, industrial, commercial, and urban development could limit the continued use of this resource. Ground-water withdrawal has caused lowering of water levels and has created cones of depression around areas of heavy ground-water use. The waterlevel decline has resulted in well interference in several localities. Continued water-level decline could result in additional well interference among the ground-water users and intrusion of saltwater into the freshwater parts of aquifers.

This report describes the hydrogeology and ground-water flow system of the Eastern Shore. A model that includes the ability to track the movement of the saltwater-freshwater interface was used to aid in the hydrologic analysis of the effects of withdrawals on the ground-water-flow system.

The sediment of the Eastern Shore forms a layered sequence of aquifers and intervening confining units. This report focuses on the aquifers and confining units (approximately the upper $300 \mathrm{ft}$ ) that make up the fresh-ground-water system. The aquifers that contain freshwater are the unconfined Columbia aquifer and the upper three confined aqui- fers, the upper, middle, and lower YorktownEastover aquifers. Maps delineating the tops of the aquifers and confining units were developed from correlation of lithologic and geophysical logs, waterquality analyses, and water-level data.

Prior to 1940 , ground-water withdrawals on the Eastern Shore were minimal, and the groundwater system was in a state of long-term dynamic equilibrium. Water from precipitation falling on the peninsula recharged the Columbia aquifer and flowed from the topographic highs near the center of the peninsula to discharge into streams, estuaries, the Chesapeake Bay, and the Atlantic Ocean. Some water flowed vertically through the upper YorktownEastover confining unit to recharge the confinedaquifer system. Water-level measurements made after withdrawals began on the peninsula indicated lowering of water levels and creation of cones of depression around major pumping centers.

Annual ground-water-withdrawal data for the model area were compiled by aquifer for commercial, industrial, and municipal withdrawals. Prior to 1965 , there were few large users of ground water on the Eastern Shore. By 1970, increased population along with commercial and industrial growth greatly increased the demand for the ground water. Groundwater use, excluding domestic and irrigation, was estimated to be about $5.04 \mathrm{Mgal} / \mathrm{d}$ in 1988 . The upper, middle, and lower Yorktown-Eastover aquifers supplied 36, 42, and 22 percent of the 5.039 $\mathrm{Mgal} / \mathrm{d}$ withdrawal, respectively. Major pumping centers on the Eastern Shore were located near the towns of Chincoteague, Hallwood, Accomac, Exmore, Oyster, Cheriton, and Cape Charles.

Data on chloride concentrations were compiled by aquifer to provide information on the distribution of chlorides in the study area. Chloride concentrations in each aquifer are typically lower in the middle of the peninsula than they are along the coast. Chloride concentrations increase with depth and are higher in the lower Yorktown-Eastover aquifer than in the middle and upper Yorktown-Eastover aquifers. The elevated chloride concentrations (greater than $250 \mathrm{mg} / \mathrm{L}$ ) found in the lower YorktownEastover aquifer across the peninsula near Exmore, Va., could be a result of different hydraulic properties related to the presence of an ancient Pleistocene river channel. Chloride concentrations in the lower Yorktown-Eastover aquifer are stratified, and concentrations are lower near the top than near the bottom of the aquifer. 
A model was developed for the Eastern Shore to simulate changes in ground-water-flow conditions that result from changes in hydrologic stresses. Simulation included ground-water flow both prior to ground-water pumpage and throughout the history of pumpage. The maximum simulated water-level decline since prepumping conditions was $53 \mathrm{ft}$ in the lower Yorktown-Eastover aquifer near the town of Accomac, Va. Simulated water-level gradients indicated a change in the direction of ground-water flow from prepumping conditions. Prepumping flow was from topographic highs in the center of the peninsula to the Chesapeake Bay and Atlantic Ocean. Simulated 1988 conditions show ground-water flow is being diverted toward the major pumping centers. Ground-water pumpage is supplied by an increase in vertical leakage to the confined-aquifer system from the unconfined aquifer and a decrease in vertical leakage from the confined-aquifer system to the unconfined aquifer. The simulated position of the interface between saltwater and freshwater did not change in response to historic pumpage.

Three scenarios predicted ground-water conditions that result from increasing withdrawals in southern Northampton County, in northeastern Accomack County, and throughout the peninsula at 1990 permitted rates. Simulation results indicate that water levels continue to decline as withdrawals increase and could result in well interference among major ground-water users and in a reduction in freshwater discharge to the Chesapeake Bay and Atlantic Ocean. The water-level declines associated with the increased withdrawals could cause slight movement of the saltwater-freshwater interface over a 50-year simulation period. The potential for induced vertical leakage of saltwater from overlying salty-surface-water sources into the freshwater parts of the upper Yorktown-Eastover aquifer is indicated by areas of reversed ground-water gradients caused by offshore water-level declines.

\section{REFERENCES CITED}

Back, William, 1966, Hydrochemical facies and groundwater flow patterns in the northern part of the Atlantic Coastal Plain: U.S. Geological Survey Professional Paper 498-A, 42 p.

Bal, G.P., 1977, Computer simulation model for groundwater flow in the Eastern Shore of Virginia: Virginia State Water Control Board Planning Bulletin 309, $73 \mathrm{p}$.
Bear, Jacob, 1979, Hydraulics of ground water: New York, McGraw-Hill, 569 p.

Bond, L.D., and Bredehoeft, J.D., 1987, Origins of seawater intrusion in a coastal aquifer - a case study of the Pajaro Valley: Journal of Hydrology, v. 92, p. 363-388.

Cederstrom, D.J., 1945, Geology and ground-water resources of the Coastal Plain in southeastern Virginia: Virginia Geological Survey Bulletin 63, $384 \mathrm{p}$.

Colman, S.M., Halka, J.P., Hobbs, C.H., Mixon, R.B., and Foster, D.S., 1990, Ancient channels of the Susquehanna River beneath the Chesapeake Bay and the Delmarva Peninsula: Geological Society of America Bulletin, v. 102, p. 1268-1279.

Colman, S.M., and Mixon, R.B., 1988, The record of major Quaternary sea-level fluctuations in a large Coastal Plain estuary, Chesapeake Bay, eastern United States: Palaeogeography, Palaeoclimatology, and Palaeoecology, v. 68, p. 99-116.

Cooper, H.H., Jr., 1959, A hypothesis concerning the dynamic balance of freshwater and saltwater in a coastal aquifer: Journal of Geophysical Research, v. 64 , no. 4 , p. $461-467$.

Cooper, H.H., Jr., and Jacob, C.E., 1946, A generalized graphical method for evaluating formation constants and summarizing well-field history: American Geophysical Union Transactions, v. 27, no. 4, p. 526-534.

Cushing, E.M., Kantrowitz, I.H., and Taylor, K.R., 1973, Water resources of the Delmarva Peninsula: U.S. Geological Survey Professional Paper 822, $58 \mathrm{p}$.

Essaid, H.I., 1986, A comparison of the coupled freshwater-saltwater flow and the Ghyben-Herzberg sharp interface approaches to modeling of transient behavior in coastal aquifer systems: Journal of Hydrology, v. 86, p. 169-196. 1990a, The computer model, SHARP, a quasithree-dimensional finite-difference model to simulate freshwater and saltwater flow in layered coastal aquifer systems: U.S. Geological Survey WaterResources Investigations Report 90-4130, 181 p. $1990 \mathrm{~b}$, A multilayered sharp interface model of coupled freshwater and saltwater flow in coastal systems-model development and application: Water Resources Research, v. 26, no. 7, p. 1431-1454.

Fennema, R.J., and Newton, V.P., 1982, Ground water resources of the Eastern Shore of Virginia: Virginia State Water Control Board Planning Bulletin 322, $94 \mathrm{p}$.

Glaser, J.D., 1969, Petrology and origin of Potomac and Magothy (Cretaceous) sediments, middle Atlantic Coastal Plain: Maryland Geological Survey Report of Investigations 11, $101 \mathrm{p}$. 
Hack, J.T., 1957, Submerged river system of Chesapeake Bay (Maryland-Virginia): Geological Society of America Bulletin, v. 68, no. 7, p. 817-830.

Hamilton, P.A., and Larson, J.D., 1988, Hydrogeology and analysis of the ground-water flow system in the Coastal Plain of southeastern Virginia: U.S. Geological Survey Water-Resources Investigations Report $87-4240,175 \mathrm{p}$.

Hansen, H.J., 1969, Depositional environments of subsurface Potomac Group in southern Maryland: American Association of Petroleum Geologists Bulletin, v. 53, no. 9, p. 1923-1937.

Harsh, J.F., and Laczniak, R.J., 1986, Conceptualization and analysis of the ground-water system in the Coastal Plain aquifers of Virginia: U.S. Geological Survey Professional Paper 1404-E, 107 p.

Heath, Ralph C., 1983, Basic ground-water hydrology: U.S. Geological Survey Water-Supply Paper 2220, $84 \mathrm{p}$.

Hill, M.C., 1988, A comparison of coupled freshwatersaltwater sharp-interface and convective-dispersive models of saltwater intrusion in a layered aquifer system, in Proceedings of the VII International Conference on Computational Methods in Water Resources: New York, Elsevier, p. 211-216.

Knobel, L.L., 1985, Ground-water-quality data for the Atlantic Coastal Plain: New Jersey, Delaware, Maryland, Virginia, and North Carolina: U.S. Geological Survey Open-File Report 85-154, 84 p.

Kohout, F.E., 1964, The flow of freshwater and saltwater in the Biscayne aquifer in the Miami area, FloridaSeawater in coastal aquifers: U.S. Geological Survey Water-Supply Paper 1613-C, p. C12-C32.

Kull, T.K., and Laczniak, R.J., 1987, Ground-water withdrawals from the confined aquifers in the Coastal Plain of Virginia, 1891-1983: U.S. Geological Survey Water-Resources Investigations Report 87-4049, 37 p.

Laczniak, R.J., and Meng, A.A., III, 1988, Groundwater resources of the York-James Peninsula of Virginia: U.S. Geological Survey Water-Resources Investigations Report 88-4059, 178 p.

Larson, J.D., 1981, Distribution of saltwater in the Coastal Plain aquifers of Virginia: U.S. Geological Survey Open-File Report 81-1013, 25 p.

Lohman, S.W., 1979, Ground-water hydraulics: U.S. Geological Survey Professional Paper 708, 70 p.

Meisler, Harold, Leahy, P.P., and Knobel, L.L., 1985, Effect of eustatic sea-level changes on saltwaterfreshwater relations in the northern Atlantic Coastal Plain: U.S. Geological Survey Water-Supply Paper $2255,28 \mathrm{p}$.

Meng, A.A., III, and Harsh, J.F., 1988, Hydrogeologic framework of the Virginia Coastal Plain: U.S. Geological Survey Professional Paper 1404-C, 82 p.
Mixon, R.B., 1985, Stratigraphic and geomorphic framework of uppermost Cenozoic deposits in the southern Delmarva Peninsula, Virginia and Maryland: U.S. Geological Survey Professional Paper 1067-G, 53 p.

Robbins, E.I., Perry, W.J., Jr., and Doyle, J.A., 1975, Palynological and stratigraphic investigations of four deep wells in the Salisbury Embayment of the Atlantic Coastal Plain: U.S. Geological Survey Open-File Report 75-307, 120 p.

Sanford, Samuel, 1913, The underground water resources of the Coastal Plain province of Virginia: Virginia Geological Survey Bulletin 5, $361 \mathrm{p}$.

Sinnott, Allen, and Tibbitts, G.C., Jr., 1954, Summary of geology and ground-water resources of the Eastern Shore Peninsula, Virginia-a preliminary report: Virginia Division of Mineral Resources Circular 2, $18 \mathrm{p}$.

1957, Subsurface correlations based on selected well logs from the Eastern Shore Peninsula, Virginia: Virginia Division of Mineral Resources Circular 6, $11 \mathrm{p}$.

1968, Ground-water resources of Accomack and Northampton Counties, Virginia: Virginia Division of Mineral Resources, Mineral Resources Report 9, $113 \mathrm{p}$.

Siudyla, E.A., 1975, Ground water conditions in the Eastern Shore of Virginia: Virginia State Water Control Board Planning Bulletin 45 and Supplement, $20 \mathrm{p}$.

Siudyla, E.A., Berglund, T.D., and Newton, V.P., 1977, Ground water of the Middle Peninsula, Virginia: Virginia State Water Control Board Planning Bulletin $305,45 \mathrm{p}$.

Siudyla, E.A., May, A.E., and Hawthorne, D.W., 1981, Ground water resources of the Four Cities area, Virginia: Virginia Water Control Board Planning Bulletin $331,168 \mathrm{p}$.

Theis, C.V., 1935, The relation between the lowering of the piezometric surface and the rate and duration of discharge of a well using ground-water storage: American Geophysical Union Transactions, v. 16, p. 510-524.

U.S. Environmental Protection Agency, 1989, Proposed rule, National primary and secondary drinking water regulations: U.S. Federal Register, v. 54, no. 97, May 22, 1989, p. 22, 160.

Volker, R., and Rushton, K., 1982, An assessment of the importance of some parameters for seawater intrusion in aquifers and a comparison of dispersive and sharp-interface modelling approaches: Journal of Hydrology, v. 56, p. 239-250.

Werkheiser, W.H., 1990, Hydrogeology and groundwater resources of Somerset County, Maryland: Maryland Geological Survey Bulletin 35, 156 p. 